\title{
JURNAL PENDIDIKAN AGAMA ISLAM
}

Volume 02, Nomor 01, Mei 2014

ISSN: 2089-1946

TAKSONOMI TRANSENDEN (PARADIGMA BARU TUJUAN PENDIDIKAN ISLAM

Ah. Zakki Fuad

INTERNALISASI NILAI_NILAI KESADARAN LINGKUNGAN MELALUI PENDIDIKAN (PERSPEKTIF AL-QUR'AN DAN AL-HADITS)

Ahmad Yusam Thobroni

SIGNIFIKANSI MAQAMAT DAN AMALAN PADA PENDIDIKAN TASAWUF DALAM PERUBAHAN TINGKAH LAKU MANUSIA

Mihmidaty

ACADEMIC DISHONESTY 'VERSUS' PAKTA INTEGRITAS DAN PRESTISE SEKOLAH DALAM PELAKSANAAN UJIAN NASIONAL

Achmad Zaini

SUMBER BELAJAR DALAM TEORI PANCARAN (TELAAH FILOSOFIS TENTANG PENDIDIKAN)

Abd. Kadir

KONSERVASI PENDIDIKAN KARAKTER ISLAMI DALAM HIDDEN CURRICULUM SEKOLAH

Fathurrohman 
PENGEMBANGAN IPTEK DALAM TINJAUAN HUKUM ISLAM

Al Quddus Nofiandri Eko Sucipto Dwijo

$\{144-166\}$

REDEFINISI PERAN GURU MENUJU PENDIDIKAN ISLAM

BERMUTU

Mukani

$\{167-188\}$

MANUSIA DALAM KONTEKS PEDAGOGIS

Sutikno

$\{189-218\}$ 


\title{
TAKSONOMI TRANSENDEN (PARADIGMA BARU TUJUAN PENDIDIKAN ISLAM)
}

\author{
Ah. Zakki Fuad \\ (Dosen PAI FTK UIN Sunan Ampel Surabaya)
}

\begin{abstract}
:
The Taxonomy of the Objectives of Islamic Education in the Qur'anic Perspective. This study is initiated from a thought that "the objective of Islamic education is to make students good". The word "good" becomes the key as well as the entrance to formulate the objective of Islamic education in this study, namely by examining the concept of "good" in the Qur'an. The concept studied by using a model of thematic tafsir (mawdhu'iy) approach. With this approach the word "good" was sought through three stems, i.e., the words ahsana-yuhsinu, saluha-yasluhu and khairun with their various shapes and changes in al-Qur'an. Then the classification arranged using the theory of taxonomy. The focus of this research conducted is: How is the taxonomy of the objectives of Islamic education in the Qur'an perspective. The finding this research of the objectives of Islamic education taxonomy is called the Trancendent Taxonomy. Namely the classification of the objectives of Islamic education which is divided into three dimensions based on the Holy Qur'an, these are ilahiyyah (divinity), insaniyyah (humanity) and kauniyyah (naturality) dimensions.
\end{abstract}

Keywords: Taxonomy, Objectives of Education, Islam, dan AlQur'an 


\section{A. Pendahuluan}

Pendidikan Islam jika dipahami sebagai sebuah proses, maka diperlukan rumusan sistem dan tujuan yang baik. Hal ini disebabkan pendidikan tanpa tujuan yang jelas niscaya akan menghilangkan nilai hakiki pendidikan. ${ }^{1}$ Oleh karena itu tujuan dalam sebuah proses pendidikan merupakan unsur yang sangat penting dalam kegiatan belajar mengajar di lembaga pendidikan. Hal ini yang menjadikan semua aktifitas kependidikan, unsur dan komponen yang terlibat serta sistem pendidikan yang dibangun, semua harus diarahkan untuk mencapai hasil maksimal dalam mencapai tujuan pendidikan sesuai dengan rumusan yang telah ditetapkan.

Tujuan adalah sesuatu yang diharapkan ketika sebuah proses kegiatan itu selesai, ${ }^{2}$ sementara itu pendidikan, khususnya pendidikan Islam merupakan sebuah kegiatan yang berproses melalui tahapan-tahapan dan tingkatan, maka tujuan pendidikan itu harus sesuai dengan tahapan, klasifikasi tingkatan yang dinamis, karena tujuan pendidikan Islam bukan merupakan sesuatu benda yang berbentuk tetap dan statis, tetapi tujuan pendidikan Islam harus berkembang dinamis sesuai dengan situasi dan kondisi peserta didik dan perkembangan zaman.

Tujuan pendidikan Islam bila ditinjau dari aspek historis, maka akan mengalami dinamika seirama dengan kepentingan dan perkembangan masyarakat dimana pendidikan itu dilaksanakan. Seperti halnya tujuan pendidikan masa Nabi Muhammad SAW dengan dinamika masyarakatnya yang sederhana berbeda jauh dengan tujuan pendidikan Islam abad IV M apalagi pada abad modern saat ini. ${ }^{3}$

\footnotetext{
1 M. Arifin, Ilmu Pendidikan Islam (Jakarta: Bumi Aksara, 2008), 23

2 Zakiyah Daradjat, Ilmu Pendidikan Islam (Jakarta: Bumi Aksara, 2009), 29

${ }^{3}$ Amin Abdullah, Falsafah Kalam di Era Post Modernisme (Yogyakarta: Pustaka Pelajar, 1995), 10-13.
} 
Perkembangan zaman inilah yang menyebabkan tujuan pendidikan Islam menjadi dinamis dan transformatif. Tetapi terkadang tujuan pendidikan Islam itu juga bersifat ideal-statis, dalam arti rumusannya tetap, tetapi derajat kualitasnya berubah dan berkembang. Namun yang harus digaris bawahi, bahwa tujuan pendidikan tersebut tidak boleh melepaskan diri dari nilai-nilai ilahiyyah, akibat dinamika ini, para ahli pendidikan Islam berbeda dalam menentukan rumusan pendidikan Islam. Antara para ahli satu dengan yang lain berbeda pandangan sesuai disiplin ilmunya masing-masing serta latar belakang kondisi sosial yang beragam.

Sekarang ini, tujuan pendidikan Islam banyak dirumuskan sesuai dengan keinginan guru, program institusi, kepentingan penguasa negara dan pembuat kebijakan, hasil konferensi, hasil lokakarya, hasil kongres, seminar ${ }^{4}$ atau pesanan golongan tertentu yang terkadang kurang mempertimbangkan landasan filosofis dan sumber nilai-nilai ilahiyyah dari perumusan tujuan pendidikan tersebut.

Bukti penguasa negara Indonesia bisa berpengaruh pada tujuan pendidikan adalah transformasi rumusan tujuan pendidikan sejak zaman orde lama, orde baru dan zaman reformasi sekarang ini. Rumusan tujuan pendidikan yang secara makro lebih dikenal dengan tujuan pendidikan nasional selalu mengalami perubahan yang substantif dari masa ke masa. Hal ini mengakibatkan tujuan pendidikan nasional akan selalu berubah sesuai dengan kepentingan pembuat rumusan yang akan dimasuki berbagai kepentingan-kepentingan kelompok, golongan atau legislator di pemerintahan. Bahkan

\footnotetext{
${ }^{4}$ Seperti kongres Second World Conference on Muslim Education, International Seminar on Islamic Concepts and Curricula, Recommendation,15"to 20", March 1980, Islamabad, Seminar Pendidikan Islam se-Indonesia tangal 7-11 Mei 1960 di Cipayung, Bogor. Kegiatan ini berusaha merumuskan tujuan pendidikan Islam yang diharapkan bisa dipakai oleh lembaga pendidikan Islam.
} 
kadang memunculkan penolakan-penolakan dari kelompok tertentu dalam negara.

Persoalan-persoalan di atas menjadi dasar pentingnya kajian dalam tulisan ini, untuk mencari jawabannya dengan cara menggali langsung dari al-Qur'an. Tulisan ini menjadikan al-Qur'an sebagai pijakan dan landasan filosofis serta sumber teori untuk merumuskan tujuan pendidikan Islam, karena alQur'an memuat banyak keilmuan yang masih belum digali secara serius. Dalam hal ini penulis menggunakan metode tafsir tematik (mawdhu'iy) untuk menggali data dari ayat-ayat alQur'an.

\section{B. Pengertian Taksonomi}

Term taksonomi sebenarnya bukan khusus untuk bidang pendidikan, term taksonomi pendidikan ini baru dipopulerkan oleh Benjamin S. Bloom pada tahun 1956 M, kemudian direvisi oleh Kratwohl \& Anderson pada tahun 1964 M, dikembangkan oleh Collis and Biggs pada tahun 1982 M, ditulis dalam sebuah disertasi oleh Ghazali Mustapha pada tahun1998 M dan digunakan dalam bidang Matematika oleh Hartanto Sunardi pada tahun 2006 M. Sampai saat ini beberapa ilmuwan masih meneliti taksonomi dalam berbagai bidang termasuk bidang pendidikan.

Awalnya istilah taksonomi sudah ada sejak zaman sebelum masehi yang dikenal dengan taksonomi klasik (classical taxonomy) yang dikemukakan oleh Artistoteles pada tahun 384-322 SM. Kemudian dikembangkan pada bidang biologi oleh Charles Darwin dengan cara mengelompokkan berbagai objek kedalam kategori dan hirarki kemudian muncul dan berkembang menjadi dasar dari taksonomi biologi.

Pada bidang biologi khususnya taksonomi tumbuhan dan hewan, sudah mulai maju dan berkembang pada tahun 
1852 M, di antaranya dikemukakan oleh G.C Wittstein dalam bukunya Etymologisch Botanisches Handworterbuch yang berisi tentang taksonomi botani. Tahun $1931 \mathrm{M}$ J.C. Willis dalam bukunya A Dictionary of Flowering Plants and Ferns juga telah memakai istilah taksonomi dalam memetakan sel-sel tumbuhan. ${ }^{5}$

Pada tahun 1990 M taksonomi juga dipakai dalam bidang perpustakaan digital (information retrieval system) dan sistem komputer yang dapat dipakai membantu penggunanya mencocokkan istilah dalam sistem komputer terutama dalam mengorganisasikan informasi dan dokumen. ${ }^{6}$

Islam pada dasarnya juga mengenal taksonomi sejak lama, yaitu sejak Nabi Adam as ketika diperkenalkan oleh Allah SWT tentang nama-nama benda, hewan dan tumbuhan di alam semesta. Hal ini tersirat dalam firman Allah SWT:

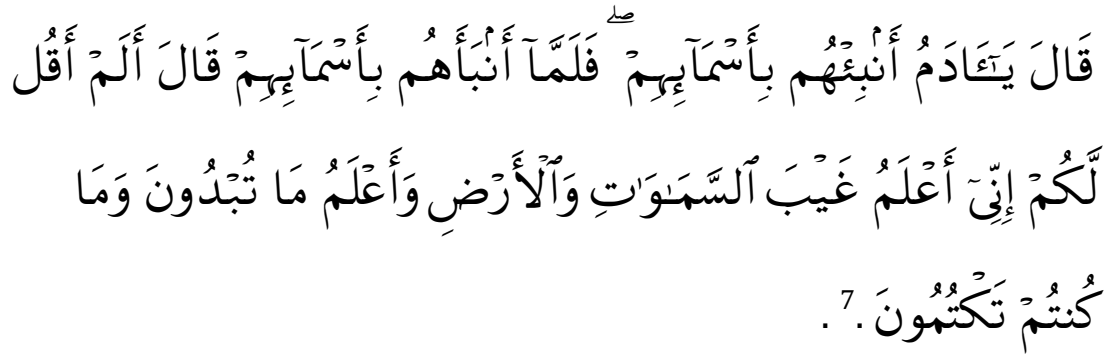

"Allah SWT berfirman: "Hai Adam, beritahukanlah kepada mereka nama-nama benda ini." Maka setelah diberitahukannya kepada mereka nama-nama benda itu, Allah berfirman: "Bukankah sudah Ku katakan kepadamu, bahwa sesungguhnya Aku mengetahui rahasia langit dan

${ }^{5}$ Gembong Tjitrosoepomo, Taksonomi Umum (Yogyakarta: UGM Press, 2005), 210.

6 Taxonomy dalam http//www.perpuspedia/ensiklopedi perpustakaan.edu. (16 Juni 2011).

${ }^{7}$ Al-Qur'an, 2:33. 
bumi dan mengetahui apa yang kamu lahirkan dan apa yang kamu sembunyikan?"."

Ayat lain yang mengandung unsur taksonomi adalah ketika Allah SWT mengajarkan Adam as nama-nama benda yanga ada di alam semesta. Firman Allah SWT:

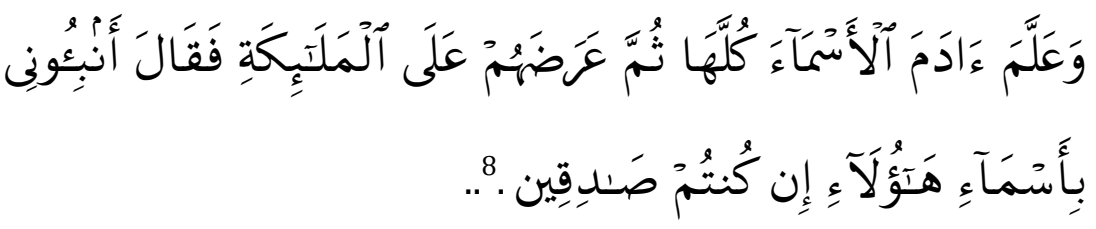

"Dan Dia mengajarkan kepada Adam nama-nama (bendabenda) seluruhnya, kemudian mengemukakannya kepada para Malaikat lalu berfirman: "Sebutkanlah kepada-Ku nama benda-benda itu jika kamu memang orang-orang yang benar".

Dua ayat di atas menyiratkan teori taksonomi yang ada dalam Islam, dimana saat itu Nabi Adam as sudah diajarkan oleh Allah SWT tentang klasifikasi benda, tumbuhan, hewan yang ada di alam semesta ini. Inilah ayat yang menjadi dasar bahwa Islam juga mengenal teori taksonomi.

Adapun makna taksonomi sendiri sangat beragam, keragaman makna tersebut secara substansi mempunyai kesamaan, yaitu ilmu tentang klasifikasi. Taksonomi diantaranya dapat diartikan sebagai klasifikasi bidang ilmu, kaidah dan prinsip yang meliputi pengklasifikasian objek, klasifikasi unsur bahasa menurut hubungan hirarkis, urutan satuan fonologis atau gramatikal yang dimungkinkan di satuan bahasa. ${ }^{9}$ Sedangkan menurut istilah ilmiah, taksonomi berarti

\footnotetext{
${ }^{8}$ Al-Qur'an, 2: 31.

${ }^{9}$ Kamus Besar Bahasa Indonesia (Jakarta: Balai Pustaka, 2005), 1125. 
unsur-unsur bahasa menurut hubungan hirarkis. ${ }^{10}$ Taksonomi juga bisa semakna dengan kategori. ${ }^{11}$

Taksonomi adalah suatu klasifikasi khusus yang berdasarkan data penelitian ilmiah mengenai hal-hal yang digolong-golongkan dalam sistematika. ${ }^{12}$ Salah satu klasifikasi khusus yang dimaksud dalam penelitian ini adalah klasifikasi tujuan-tujuan pendidikan. Tujuan (objective) pendidikan menunjukkan apa yang harus dicapai peserta didik sebagai hasil belajar yang dituangkan dalam "rumusan eksplisit untuk mengubah performa peserta didik melalui proses pendidikan". ${ }^{13}$ Di Indonesia, taksonomi yang banyak dikenal di dunia pendidikan diantaranya adalah Taksonomi Bloom, Taksonomi SOLO (Structure of Observed Learning Outcomes) serta Taksonomi Cogaff (kognitif dan afektif).

Membuat teori taksonomi berarti mengklasifikasi sebuah temuan keilmuan, memetakan, mengkategorikan dengan unsur bahasa yang bisa dipahami. Seperti klasifikasi kecil sampai besar, klasifikasi mudah sampai sulit, klasifikasi ringan sampai berat, klasifikasi lama sampai baru, klasifikasi tradisional sampai modern, klasifikasi rendah sampai tinggi, klasifikasi bawah sampai atas atau sebaliknya. ${ }^{14}$

10 M. Dahlan dkk, Kamus Induk Istilah Ilmiah (Surabaya: Target Press, 2003), 757

11 Gembong Tjitrosoepomo, Taksonomi Umu,.55.

12 Anderson, International Encyclopedia of Teaching and Teacher Education (Oxford: Pergamon Press, 1995), 17.

${ }^{13}$ Anderson. Orin W and David R.Krathwohl, A Taxonomi for Learning, Teaching and Assassing (A Revision of Bloom's Taxonomi of Educational Objective (New York: Longman Press, 2001), 4.

${ }^{14}$ Seperti dalam taksonomi tumbuhan yang ditulis oleh Joseph Pitton de Tournefort pada tahun $1716 \mathrm{M}$ yang berjudul Institutiones Rei Herbariae yang mengklasifikasikan tumbuhan dari bawa ke atas menjadi genus (marga) familia (suku) - ordo (bangsa) - classis (kelas) - division (divisi) - regnum (dunia). Lihat Gembong Tjitrosoepomo, Taksonomi Umum, 63. 
Klasifikasi-klasifikasi yang didasarkan pada teori taksonomi itu nantinya akan disusun secara sistematis, hirarkis, kategorik sehingga bisa aplikatif dipakai untuk kebutuhan dalam merumuskan tujuan pendidikan Islam dalam perspektif al-Qur'an. Intinya tujuan pendidikan Islam yang akan ditemukan dalam penelitian ini merupakan klasifikasi data-data yang diperoleh dari al-Qur'an tentang tujuan pendidikan Islam.

\section{Taksonomi dalam Pendidikan dan Perkembangannya}

Teori taksonomi dalam dunia pendidikan keberadaannya sangat beragam, dari waktu ke waktu selalu mengalami perkembangan, hal ini disebabkan fokus kajian dan metode pendekatannya berbeda antara ilmuwan satu dengan yang lain. Berikut ini akan dijelaskan macam-macam teori taksonomi yang ada dalam dunia pendidikan sampai saat ini, yaitu:

\section{Taksonomi Bloom (Bloom's Taxonomy)}

Taksonomi pendidikan diperkenalkan oleh Benjamin S. Bloom pada tahun 1956 M. Menurut Bloom, tujuan pendidikan dibagi menjadi beberapa domain (ranah, kawasan) dan setiap domain tersebut dibagi kembali kedalam pembagian yang lebih rinci berdasarkan hirarkinya. Taksonomi Bloom awalnya hanya memuat ranah kognitif saja. Kemudian dikembangkan oleh Kratwohl dan Anderson pada tahun 1964 M serta Collis and Biggs pada tahun 1982 M yang pada akhirnya berkembang menjadi tiga ranah, kognitif, afektif dan psikomotorik.

Domain Kognitif meliputi: a. Pengetahuan (Knowledge), b. Pemahaman (Comprehension), c. Aplikasi (Application), d. Analisis (Analysis), e. Sintesis (Synthesis), f. Evaluasi (Evaluation). Domain Afektif terdiri dari: a. Penerimaan 
(Receiving/Attending), b. Tanggapan (Responding), c. Penghargaan (Valuing), d. Pengorganisasian (Organization), e. Karakterisasi Berdasarkan Nilai (Characterization by a Value Complex). Domain Psikomotor mengandung: a. Persepsi (Perception), b. Kesiapan (Set), c. Respon Terpimpin (Guided Response), d. Mekanisme (Mechanism), e. Respon Tampak yang Kompleks (Complex Overt Response), f. Penyesuaian (Adaptation), g. Penciptaan (Origination). ${ }^{15}$

\section{Taksonomi SOLO (Structure of Observed Learning Outcomes)}

Taksonomi SOLO (Structure of Observed Learning Outcomes) yang ditulis dan dipopulerkan oleh Biggs \& Collis tahun $1982 \mathrm{M}$ adalah suatu taksonomi yang digunakan untuk mengklasifikasikan respons terhadap tugas-tugas mata kuliah mahasiswa. Taksonomi ini meliputi lima level yaitu: a. Prastruktural, b. Unistruktural, c. Multistruktural, d. Relasional, e. Abstrak lanjut (extended abstract). ${ }^{16}$

\section{Taksonomi SOLO Plus (TSP)}

Taksonomi SOLO Plus (TSP) adalah hasil temuan Hartanto Sunardi dalam Disertasi yang ditulis tahun 2006. Taksonomi SOLO Plus (TSP) ini merupakan pengembangan dan penghalusan dari taksonomi SOLO yang sudah ada sebelumnya. Taksonomi ini terdiri dari tujuh level, yaitu: a. Level 1: Prastruktural; b. Level 2: Unistruktural; c. Level 3: Multistruktural; d. Level 4: Semirelasional; e. Level 5:

\footnotetext{
15 Benyamin S. Bloom, Taksonomy of Educational Objectives, The Clasification of Educational Goals, Handbook 1 Cognitive Domain (London: Longman Group Ltd, 1979), 23-30.

${ }^{16}$ Biggs dan Collis, Evaluating the Quality of Learning; The SOLO Taxonomy (New York: Academic Press, 1982), 45.
} 
Relasional; f. Level 6: Abstrak; g. Level 7: Extended abstract. ${ }^{17}$

Kajian ini akan mengembangkan suatu taksonomi SOLO menjadi Taksonomi SOLO Plus (TSP). Pengembangan pertama dilakukan secara teoretis melalui kajian dan refleksi dari teori-teori yang ada, dan dilanjutkan secara empiris melalui penelitian kualitatif.

\section{Taksonomi Cogaff (Cognitive and Affective)}

Taksonomi ini ditulis oleh Ghazali Mustapha pada tahun 1998 dalam Disertasi di Fakulti Pengajian Pendidikan Universitas Putra Malaysia Serdang tahun 1998 yang diberi nama taksonomi cogaff. Terminologi cogaff lahir dari gabungan perkataan cognitive dan affective. Taksonomi cogaff dilahirkan berdasarkan integrasi taksonomi domain kognitif (yang dipopulerkan oleh Bloom pada tahun 1956) dan taksonomi domain afektif (yang diperkenalkan oleh Krathwohl pada tahun 1964).

Taksonomi cogaff mengambil dua domain kognitif dan afektif sebagai landasan untuk mengembangkan kecerdasan berfikir. Secara klasifikatif taksonomi cogaff disusun sebagai berikut: a. Pengetahuan, b. Kefahaman, c. Aplikasi, d. Analisis, e. Sintaksis, f. Penilaian, g. Afektif. ${ }^{18}$

\section{Taksonomi Tujuan Pendidikan Islam}

Kajian ini dimulai dari sebuah pemikiran filosofis, bahwa "Tujuan Pendidikan Islam itu harus menjadikan peserta

17 Hartanto Sunardi, "Pengembangan Taksonomi Solo menjadi Taksonomi Solo Plus (Disertasi: UNESA, Surabaya, 2006), 6.

18 Ghazali Mustapha, "Taksonomi Cogaff" (Disertasi: Fakulti Pengajian Pendidikan Universitas Putra Malaysia-Serdang, 1998), 9. 
didik menjadi baik". Kata "baik" ini adalah kunci dan pintu masuk dalam merumuskan tujuan pendidikan Islam dalam kajian ini dengan cara meneliti konsep "baik" dalam al-Qur'an.

Untuk meneliti kata "baik" dalam al-Qur'an tersebut, penulis menggunakan metode tematik (mawdhu'iy). Dengan metode ini diharapkan bisa menggali rumusan dan teorisasi tujuan pendidikan Islam yang murni bersumber dari al-Qur'an. Dengan model pendekatan tafsir tematik (mawdhu'iy) ini penulis memulai dengan cara mencari kata "baik" melalui tiga akar kata, yaitu kata ahsana-yuhsinu ( حس - يحس ) dan

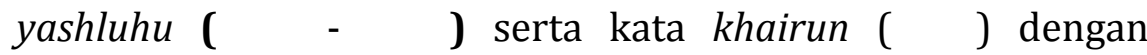
bentuk dan perubahannya dalam al-Qur'an. Kemudian dari tiga akar kata tersebut ditelusuri lagi akar kata yang mempunyai korelasi dengan ayat lain sampai ketemu klasifikasi "baik" itu seperti apa dalam al-Qur'an. ${ }^{19}$

Kata ahsana-yuhsinu ( حس - ححس ) dengan segala perubahannya dalam al-Qur'an disebut sebanyak 200 kali pada ayat dan surat yang berbeda. Sedangkan kata shaluhayashluhu (صلح-ح) dengan berbagai bentuk dan perubahannya dalam al-Qur'an disebut sebanyak 180 kali pada ayat dan surat yang berbeda. Kata khairun ( dalam al-Qur'an sebanyak 109 ayat dan 39 surat yang berbeda.

Dari kata kunci di atas bisa dipahami, banyaknya kata tersebut dalam ayat dan surat berbeda telah membuktikan, bahwa al-Qur'an sangat peduli dengan ketiga term tersebut dan sangat dimungkinkan untuk dilakukan sebuah kajian yang

\footnotetext{
${ }^{19}$ Penelusuran akar kata dalam penelitian ini menggunakan Software The Holly Qur'an versi 7.10, Harf information Tecnology co. tahun 2000 M. Afzalur Rahman, Indeks al-Qur'an (Jakarta: Amzah, 2009), Fuad Abd Baqi, Mu'jam alMufahras li alfâd al-Qur'an (Kairo: Dar al-Fikr, 1992), Fath al-Rahmān li al-Talb ay àt al-Qur'ān (Surabaya: al-Hidayah, 1322 H) serta CD Software Maktabah alSyamilah; Akbar Mausu'ah al-Islamiyyah, Ihdhar Thani.
} 
dapat menghasilkan teori yang klasifikatif, sistematis dan aplikatif.

Sebenarnya selain tiga akar kata tersebut, al-Qur'an juga memakai kata "al-Birru" dan kata "al-Ma'ruf " untuk term "baik", tetapi dua kata ini tidak banyak disebut dalam al-Qur'an dan tidak signifikan untuk tema yang dikaji. Pencarian akar kata "al-Birru" dan kata "al-Ma'ruf" dengan segala perubahan dalam al-Qur'an hanya disebut kurang dari 10 ayat, itupun yang mempunyai korelasi dengan tema penelitian ini hanya pada alQur'an, 2: 177 yang substansi isinya sudah masuk pada kata "khairun".

\section{Kata Kunci ahsana-yuhsinu (أحسن- يحسن)}

Penelusuran ayat-ayat al-Qur'an melalui akar kata ahsana-yuhsinu dengan segala perubahannya terdapat 200 ayat pada surat dan ayat yang berbeda. Kemudian ayat-ayat tersebut dikaji dan ditemukan setidaknya ada beberapa ayat yang mempunyai hubungan dengan tema yang dikaji. Kajian ayat-ayat tentang "baik" dengan akar kata ahsana-yuhsinu beserta indikator atau ciri-ciri orang yang berbuat baik (muhsinin) yaitu:

\section{a. Al-Qur'an, 2: 195:}

Indikator orang baik/perbuatan baik yaitu: Infak di jalan Allah, menyembah Allah, berperilaku positif (keyakinan atas keesaan Allah, kemerdekaan, kebebasan, ketenangan hidup lahir batin).

\section{b. Al-Qur'an, 2: 195:}

Indikator orang baik/perbuatan baik yaitu: Ikhlas, menjalankan perintah Allah, menjauhi larangan Allah.

\section{c. Al-Qur'an, 5: 13:}

Indikator orang baik/perbuatan baik yaitu: Memaafkan (membalas keburukan dengan kebaikan). 


\section{d. Al-Qur'an, 5: 93:}

Indikator orang baik/perbuatan baik yaitu: Beriman, bertqwa, beramal saleh.

\section{e. Al-Qur'an, 11: 115:}

Indikator orang baik/perbuatan baik yaitu: Salat, istikamah, sabar.

\section{Kata Kunci Shaluha-yaṣluhu (صلح- يصلح)}

Kata shaluha-yashluhu (صلح- يصلح) dengan berbagai bentuk dan perubahannya dalam al-Qur'an disebut 180 kali pada ayat dan surat yang berbeda. Sedangkan yang mempunyai korelasi dengan tujuan pendidikan Islam adalah:

a. Al-Qur'an, 2: 11:

Indikator orang baik/perbuatan baik yaitu: Tidak membuat kerusakan di bumi.

\section{b. Al-Qur'an, 3: 114:}

Indikator orang baik/perbuatan baik yaitu: Iman kepada Allah, iman kepada hari akhir, menyuruh berbuat baik, mencegah kemungkaran, cepat dalam melaksanakan kebaikan, membaca al-Qur'an di malam hari.

c. Al-Qur'an, 9: 75:

Indikator orang baik/perbuatan baik yaitu: Sedekah dan silaturahmi.

\section{Kata Kunci Khairun (خير)}

Kata khairun (خير ) terdapat dalam al-Qur'an sebanyak 109 ayat dan 39 surat yang berbeda. Dari 109 ayat yang dikaji, ditemukan setidaknya ada beberapa ayat yang mempunyai hubungan (munasabat) dengan tujuan pendidikan Islam sebagai berikut: 
a. Al-Qur'an, 2: 184:

Indikator orang baik/perbuatan baik yaitu: Ikhlas mengerjakan kebaikan, berpuasa.

\section{b. Al-Qur'an, 2: 215}

Indikator orang baik/perbuatan baik yaitu: Memberi nafkah kepada anak an keluarganya.

c. Al-Qur'an, 2: 220:

Indikator orang baik/perbuatan baik yaitu: Peduli dengan anak yatim.

d. Al-Qur'an, 2: 263:

Indikator orang baik/perbuatan baik yaitu: Selalu berkata dengan baik, pemaaf.

e. Al-Qur'an, 2: 271:

Indikator orang baik/perbuatan baik yaitu: Bersedekah kepada fakir miskin.

f. Al-Qur'an, 4: 25:

Indikator orang baik/perbuatan baik yaitu: Sabar dalam menerima cobaan dari Allah.

g. Al-Qur'an, 4: 59:

Indikator orang baik/perbuatan baik yaitu: Selalu berpegang teguh pada Al-Qur'an dan Hadis Nabi Muhammad SAW.

h. Al-Qur'an, 4: 114:

Indikator orang baik/perbuatan baik yaitu: Bersedekah, amar ma'ruf, selalu berdamai dengan sesama manusia.

i. Al-Qur'an, 7: 85:

Indikator orang baik/perbuatan baik yaitu: jujur dalam transaksi, tidak merusak alam dan kehidupan yang ada di bumi.

j. Al-Qur'an, 9: 3:

Indikator orang baik/perbuatan baik yaitu: Bertaubat atas segala dosa dan kesalahan. 
k. Al-Qur'an, 9: 41:

Indikator orang baik/perbuatan baik yaitu: Jihad dengan harta dan jiwa.

\section{Al-Qur'an, 24: 60:}

Indikator orang baik/perbuatan baik yaitu: Sopan santun dalam berpakaian.

Data-data dari ayat-ayat al-Qur'an yang mempunyai korelasi (munasabat) tersebut kemudian dilakukan unitizing, reducing, inferring dan analyzing. Unitizing terhadap data-data tersebut dilakukan dengan cara menyatukan dan mengelompokkan berdasarkan tema dan kebutuhan penelitian kemudian di reducing dengan merangkum dan memilih datadata yang dibutuhkan dan dilanjutkan dengan inferring atau menarik sebuah kesimpulan. Setelah dilakukan inferring diakhiri dengan analyzing atau menganalisis, menilai data yang telah direduksi sesuai dengan kontek penelitian dan mendiskripsikan secara eksplisit menjadi sebuah teori.

Hasil dari unitizing, reducing dan analyzing terhadap temuan data-data berupa ayat-ayat al-Qur'an tersebut kemudian diklasifikasi (taksonomi) sesuai dengan karakteristiknya menjadi tiga kategori. Pertama, "baik" dalam kaitannya dengan hubungan manusia dengan Tuhan oleh penulis dinamakan dengan dimensi ilahiyyah (ketuhanan/ teosentris). Kedua, "baik" dalam kaitannya dengan hubungan manusia dengan manusia dan interaksi sosial dimasyarakat dinamakan dengan dimensi insaniyyah (kemanusiaan/ antroposentris). Ketiga, "baik" dalam kaitannya dengan hubungan manusia dengan alam semesta yang dinamakan dengan dimensi kauniyyah (alam semesta/ekosentris).

Dimensi ilahiyyah (ketuhanan) adalah tujuan pendidikan Islam yang harus dicapai setelah mengikuti 
kegiatan belajar mengajar (KBM) yang mengandung hubungan antara manusia dengan Tuhannya. Dimensi insaniyyah (kemanusiaan) merupakan tujuan pendidikan Islam yang harus dicapai setelah mengikuti kegiatan belajar mengajar (KBM), di dalamnya memuat bagaiman mengatur hubungan manusia dengan dengan manusia yang lain, bagaimana cara berinteraksi sosial yang baik antara manusia dengan masyarakatnya. Sedangkan dimensi Kauniyyah (alam semesta) adalah tujuan pendidikan Islam yang harus dicapai setelah mengikuti kegiatan belajar mengajar (KBM) yang mengandung hubungan antara manusia dengan alam semesta.

Temuan tiga dimensi ini kemudian dinamakan dengan Taksonomi Transenden (Trancendent Taxonomy). Tiga dimensi tersebut diklasifikasi menjadi tujuan pendidikan Islam sesuai dengan teori taksonomi sebagai berikut:

\section{Dimensi Ilahiyyah (Ketuhanan-Teosentris):}

a. Beriman (kepada Allah, Malaikat, Kitab Allah, Rasul Allah, Hari akhir, kada \& kadar)

b. Bertakwa (Beribadah, berzikir, berpuasa, bersukur, adil)

c. menyembah Allah

d. Menjalankan perintah Allah

e. Menjauhi laranan Allah

f. Salat (Sunah: tahajud, witir, rawatib, duha, tarawih, istisqa', gerhana, jenazah. Idul fitri, idul adha, tahiyat almasjid. Wajib: Isya', subuh, duhur, asyar, maghrib).

g. Puasa (Wajib: Ramadhan, nazar. Sunah: Senin-kamis, tarwiyah-arafah, 6 hari bulan syawal).

h. Berpegang teguh pada al-Qur'an dan Hadis

i. Membaca al-Qur'an di malam hari

j. Jihad dengan harta dan jiwa, beramal saleh, ikhlas, sabar, tobat). 

k. Beramal saleh
l. Ikhlas
m. Sabar
n. Tobat

\section{Dimensi Insaniyyah (Kemanusiaan-Antroposentris)}
a. Sedekah di jalan Allah (fakir, miskin, amil, mualaf, budak, gharim, sabilillah, ibnu sabil).
b. Infak di jalan Allah (Ibu, bapak, kerabat, anak yatim, orang miskin, sabilillah).
c. Peduli kepada anak yatim
d. Silaturahmi
e. Berdamai dengan manusia
f. Jujur dalam bertransaksi
g. Cepat dalam melaksanakan kebaikan
h. Berprilaku positif
i. Pemaaf
j. Berkata baik
k. Sopan santun dalam berpakaian

\section{Dimensi Kauniyyah (Alam -Ekosentris)}

a. Tidak merusak bumi (daratan, tanah, lautan, air, hewan, ikan, tumbuhan, tanaman)

b. Tidak merusak alam (matahari, bulan, bintang, awan, hujan).

Tiga dimensi tersebut akan diskema sesuai dengan teori taksonomi di bawah ini: 
Ah. Zakki Fuad

Taksonomi 1: Dimensi Ilahiyyah (Ketuhanan)

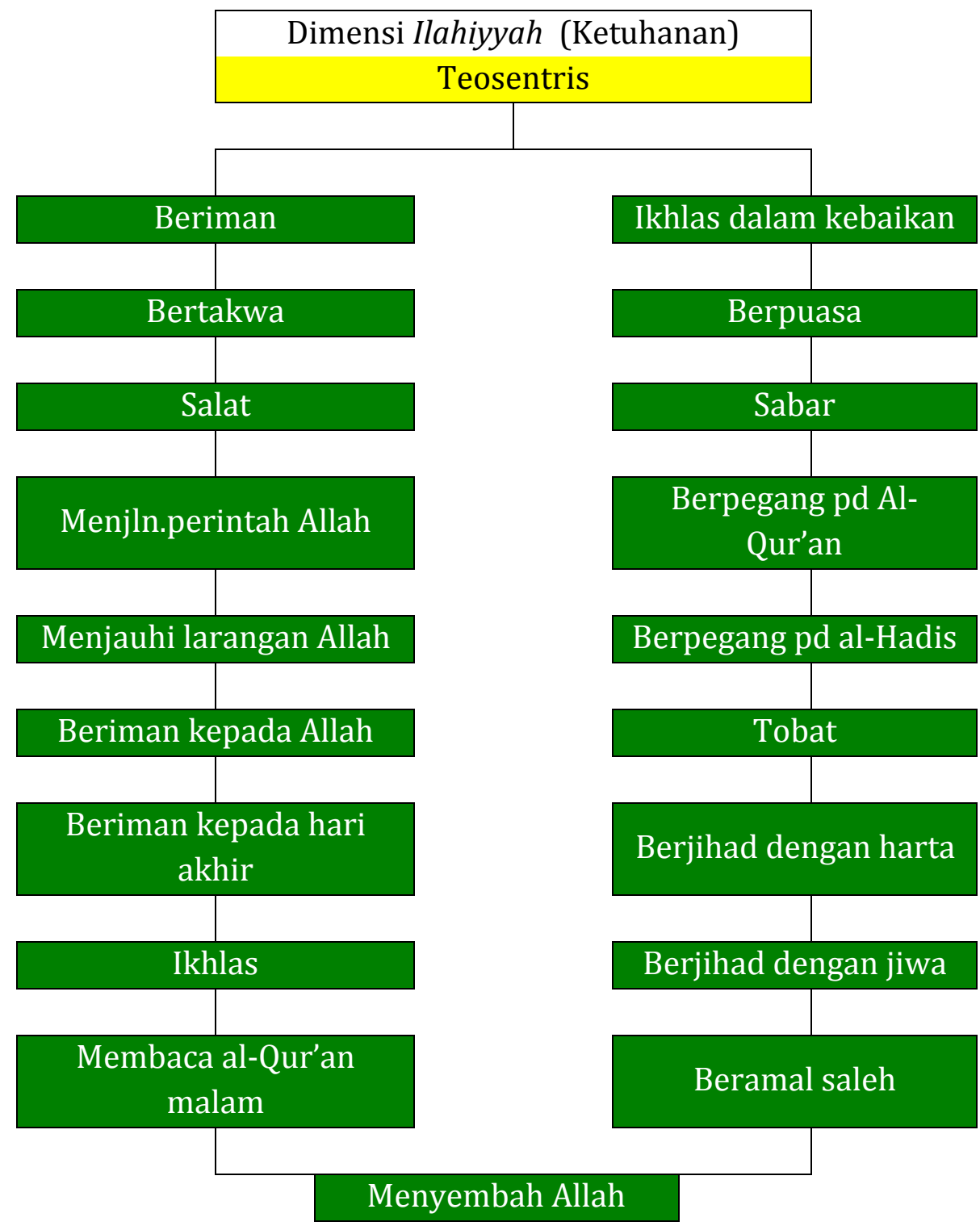

Jurnal Pendidikan Agama Islam

Volume 02 Nomor 01 Mei 2014

Hal $18-25$ 
Taksonomi 2;

Dimensi Insaniyyah (Kemanusiaan)

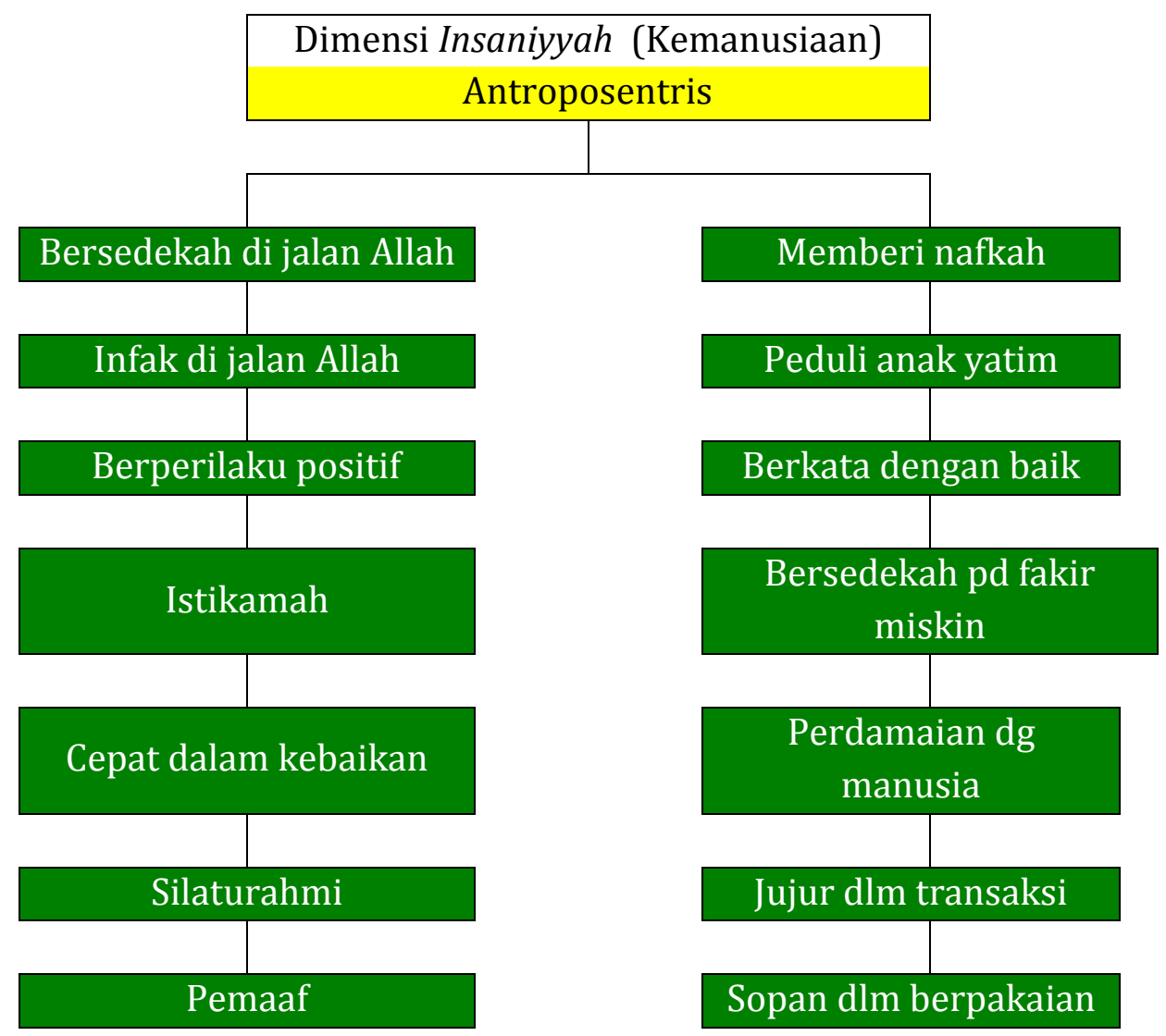


Ah. Zakki Fuad

Taksonomi 3

Dimensi Kauniyyah (Alam Semesta)

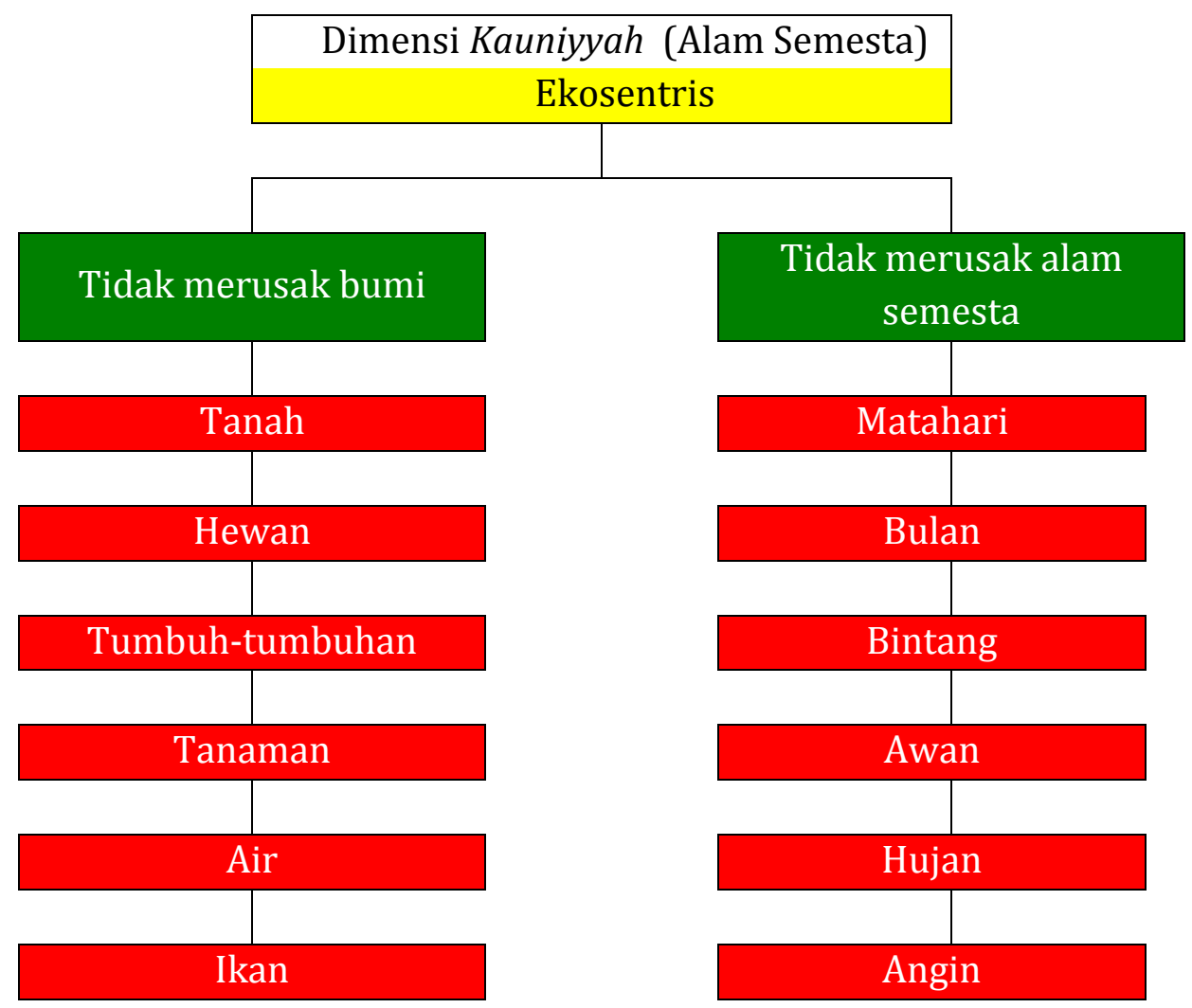

Jurnal Pendidikan Agama Islam Volume 02 Nomor 01 Mei 2014

Hal $20-25$ 
Taksonomi 4;

Taksonomi Tujuan Pendidikan Islam Perspektif al-Qur'an

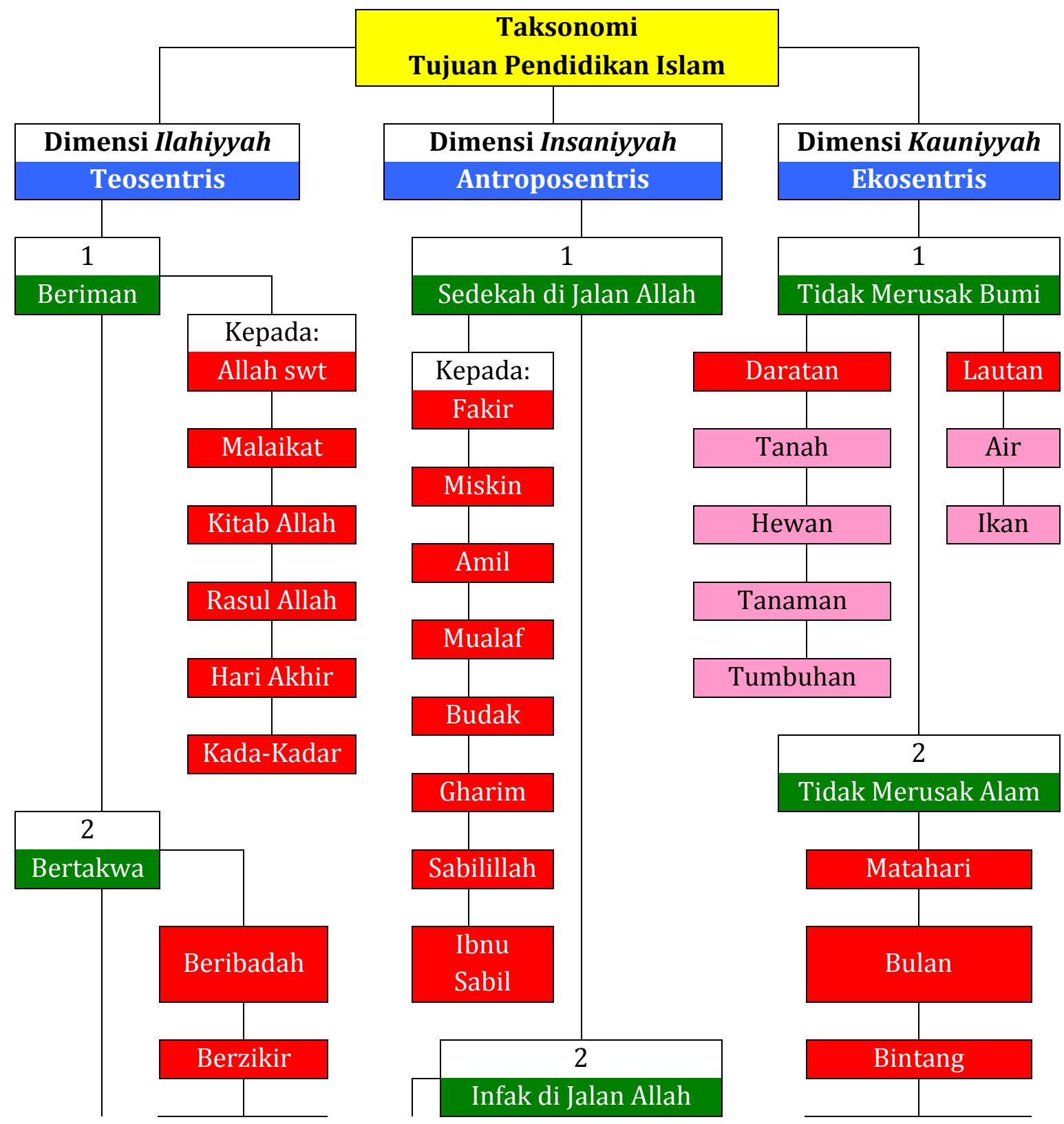


Ah. Zakki Fuad

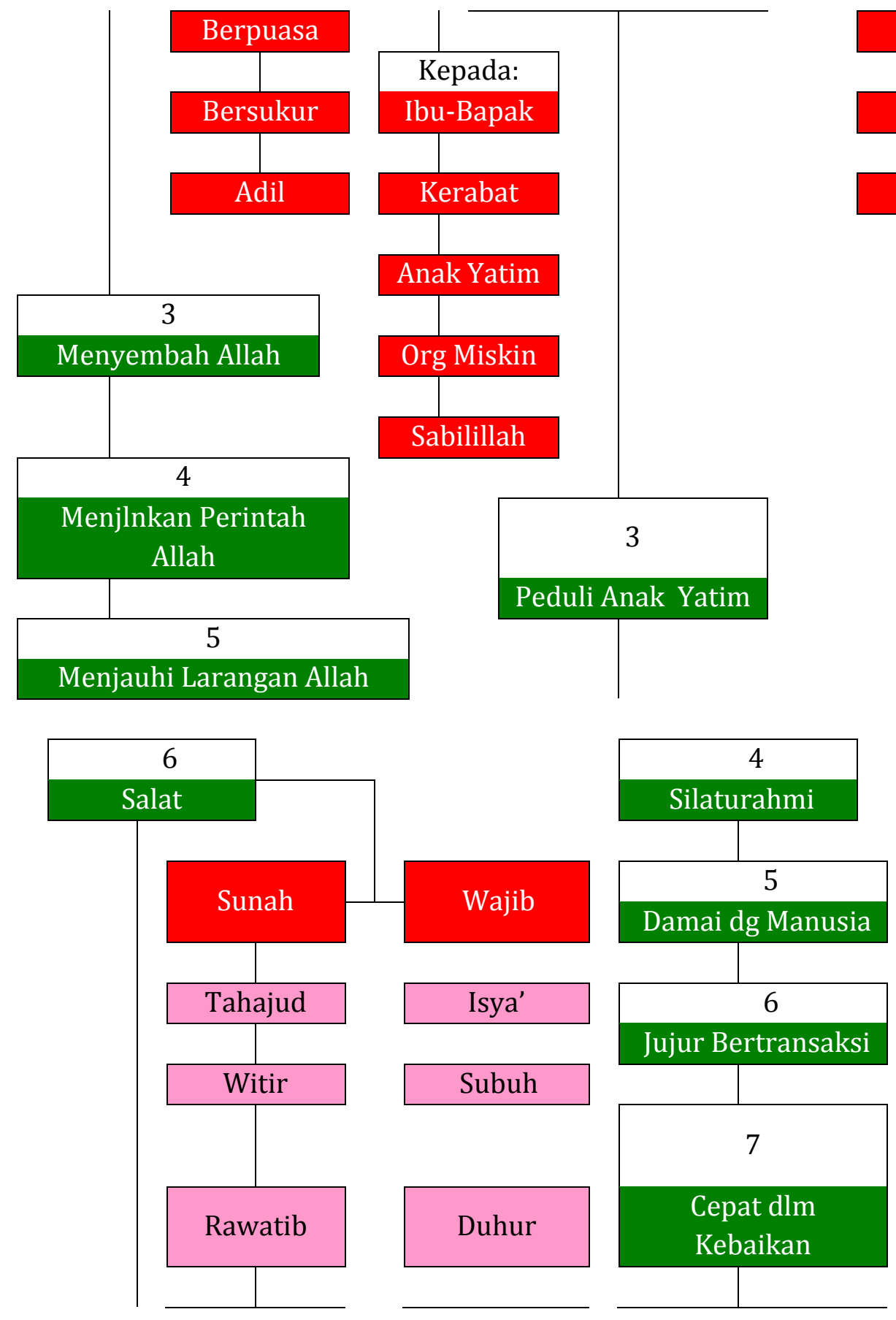

Jurnal Pendidikan Agama Islam

Volume 02 Nomor 01 Mei 2014

Hal $22-25$ 
Taksonomi Transenden (Paradigma Baru Tujuan Pendidikan Islam)

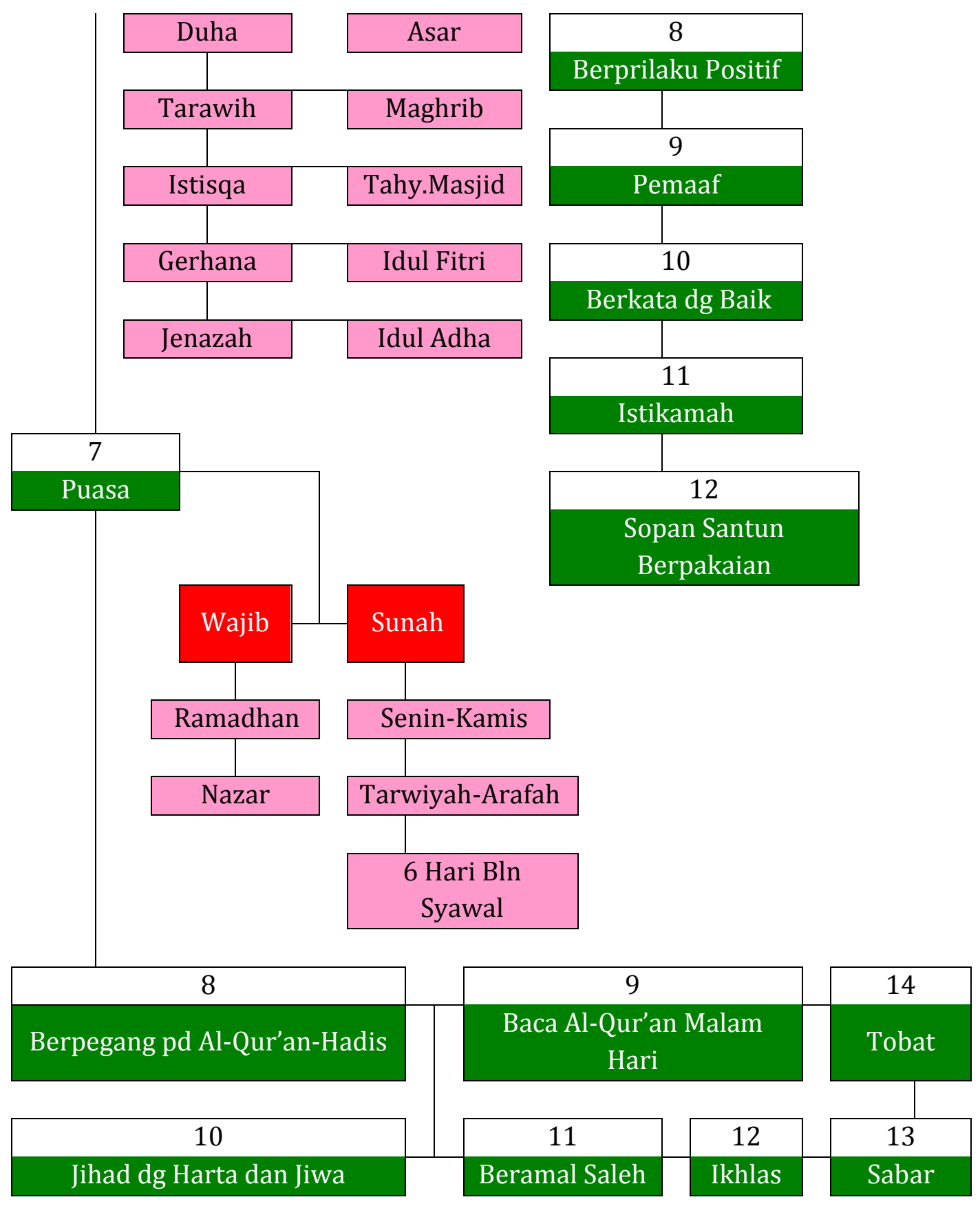




\section{E. Penutup}

Hasil kajian tentang taksonomi tujuan pendidikan Islam dalam perspektif al-Qur'an dengan menggunakan pendekatan tafsir tematik (maudhu'iy) menemukan sebuah teori tentang tujuan pendidikan Islam yang dinamakan dengan Taksonomi Transenden (Trancendent Taxonomy) yaitu tujuan pendidikan Islam yang terdiri dari tiga dimensi; Dimensi ilahiyyah/ teosentris/ ketuhanan, dimensi insaniyyah/ antroposentris/ kemanusiaan, dimensi kauniyyah/ ekosentris/ alam semesta.

Dimensi ilahiyyah (ketuhanan) adalah tujuan pendidikan Islam yang harus dicapai setelah mengikuti kegiatan belajar mengajar yang mengandung hubungan antara manusia dengan Tuhannya. Dimensi insaniyyah (kemanusiaan) merupakan tujuan pendidikan Islam yang harus dicapai setelah mengikuti kegiatan belajar mengajar yang di dalamnya memuat bagaiman mengatur hubungan manusia dengan manusia yang lain, bagaimana cara berinteraksi sosial yang baik antara manusia dengan masyarakatnya. Sedangkan dimensi Kauniyyah (alam semesta) adalah tujuan pendidikan Islam yang harus dicapai setelah mengikuti kegiatan belajar mengajar yang mengandung hubungan antara manusia dengan alam semesta. 


\section{DAFTAR PUSTAKA}

Abdurrahman Saleh Abdullah, Educational Theory a Quranic Outlook (Jakarta: Rineka Cipta, 2005).

Atiyah Al-Abrasyi, Dasar-dasar dan Pokok Pendidikan Islam (Jakarta: Bulan Bintang, 1998).

Afzalurrahman, Indeks al-Qur'an (Jakarta: Amzah, 2009).

Anderson, International Encclopedia of Teaching and Teacher Education (Oxford: Pergamon Press, 1995).

Abd Hayy Farmawi, Al-Bidayah fi al-Tafsir Maudhu'i, terj. Suryan A.

J. (Jakarta: Raja Grafindo, 1996).

Amin Abdullah, Falsafah Kalam di Era Post Modernisme

(Yogyakarta: Pustaka Pelajar, 1995).

Arifin, Ilmu Pendidikan Islam (Jakarta: Bumi Aksara, 2008).

Anton Bakker, Metodologi Penelitian Filsafat (Yogyakarta:

Kanisius, 1992).

Benyamin S. Bloom, Taksonomy of Educational Objectives, The Clasification of Educational Goals, Handbook 1 Cognitive Domain (London: Longman Group Ltd., 1979).

Fuad Abdul Baqi, Mu'jam al-Mufahras li Alfâd al-Qur'an (Kairo: Dar al-Fikr, 1992).

J. Biggs \& Collis, K. F., Evaluating the Quality of Learning: The SOLO Taxonomy (New York: Academic Press, 1982).

Klass Krippendorff, Analisis Isi Pengantar Teori dan Metodologi, terj. Farid Wajidi (Jakarta: Raja Grafindo, 1993).

Orin W Anderson and David R. Krathwoh, A Taxonomi for Learning, Teaching and Assassing (A Revision of Bloom's Taxonomi of Educational Objective (New York: Longman Press, 2001).

Zakiyah Daradjat, Ilmu Pendidikan Islam (Jakarta: Bumi Aksara, 2009).

Al-Bidayah fi al-Tafsir Maudhu'i, Dirasah Manhajiyyah Maudu'iyyah, terj. Rosihan Anwar (Bandung, 2002). 


\title{
INTERNALISASI NILAI-NILAI KESADARAN \\ LINGKUNGAN MELALUI PENDIDIKAN (Perspektif Al- Quran dan Al-Hadits)
}

\author{
Ahmad Yusam Thobroni \\ (Kaprodi PAI Jurusan PI FTK UIN Sunan Ampel)
}

\begin{abstract}
Abstrak:
Pengelolaan lingkungan harus berpijak pada prinsip-prinsip dan nilai-nilai al-Quran, yaitu: seluruh alam raya beserta isinya adalah milik Tuhan dan ciptaan-Nya; seluruh isi alam diperuntukkan bagi manusia dan makhluk hidup lainnya; alam ini ditundukkan agar dapat dikelola oleh manusia; manusia dititipi amanah oleh Tuhan untuk mengelola lingkungan; sebagai khalifah, manusia bertugas mengantarkan lingkungan untuk mencapai tujuan penciptaannya; pemborosan harus dicegah; kerusakan lingkungan adalah akibat perbuatan manusia, dan oleh karena itu manusia harus bertanggungjawab di dunia dan di akhirat; dan kasih sayang manusia kepada seluruh makhluk bermakna menghargai seluruh makhluk dan memperlakukannya dengan baik. Untuk menanamkan nilainilai kesadaran lingkungan berdasarkan spiritualitas Islam tersebut perlu diupayakan melalui proses pendidikan yang sistematis dan sinergis dengan memberikan perhatian khusus berupa pembentu kan kurikulum pendidikan yang bernuansa kesadaran pelestarian lingkungan bagi subjek didik sejak dini. Dengan upaya ini diharapkan terwujudnya kelestarian lingkungan hidup yang semakin nyata dan membawa kepada kesejahteraan umat manusia.
\end{abstract}

Kata Kunci: Kesadaran Lingkungan, Pendidikan, Al-Quran dan Al-Hadits 


\section{A. Pendahuluan}

Manusia diciptakan oleh Tuhan sebagai khalifah-Nya (pengganti ${ }^{1}$ Tuhan) di muka bumi. Oleh karena itu, manusiadalam menjalani kehidupannya di muka bumi yang menjadi lingkungannya ini-menduduki posisi sentral dalam mengelola lingkungannya ${ }^{2}$ secara baik dan benar guna memenuhi kebutuhan hidupnya, demi mencapai kemaslahatan (kesejahteraan). Sebaliknya, kesalahan dalam pengelolahan lingkungan tidak saja akan mengancam kelangsungan dan kelestariannya, tetapi juga dapat berakibat fatal bagi kehancuran umat manusia itu sendiri. Tuhan mengancam akan memberikan siksaan dengan cepat bagi para pengelola sumber daya alam yang bertindak sewenang-wenang. Allah SWT. menegaskan dalam QS. al-An'ām (6):165;

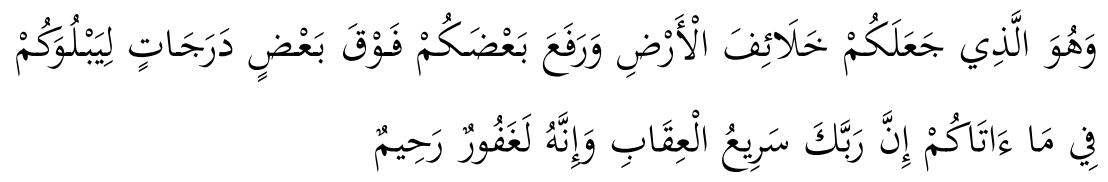

"Dan Dialah yang menjadikan kamu penguasa-penguasa di bumi dan Dia meninggikan sebahagian kamu atas sebagian (yang lain) beberapa derajat, untuk mengujimu tentang apa yang diberikan-Nya kepadamu. Sesungguhnya Tuhanmu amat cepat siksaan-Nya, dan sesungguhnya Dia Maha Pengampun lagi Maha Penyayang."3

\footnotetext{
${ }^{1}$ Kata خليفـ diterjemahkan dengan "pengganti". Lihat Ahmad Warson Munawwir, al-Munawwir Kamus Arab - Indonesia (Yogyakarta: UPBIK Pondok Pesantren Al-Munawwir, 1984), 392

${ }^{2}$ Lingkungan (alam) ialah keadaan sekitar yang mempengaruhi perkembangan dan tingkah laku organisme (yang terdiri dari wilayah laut, darat, dan udara). Lihat Tim Penyusun, Kamus Besar Bahasa Indonesia (Jakart: Balai Pustaka, 1989), 526

3 Departemen Agama R.I., Al Qur'an dan Terjemahnya, (Jakarta: Bumi Restu, 1975/1976), 217
} 
Ayat di atas secara tegas mengisyarahkan bahwa lingkungan yang merupakan anugerah Allah SWT. ini adalah ujian bagi manusia. Ujian untuk tidak merusak lingkungan; seperti aktifitas penebangan pohon di hutan-hutan secara membabi buta untuk pembukaan lahan perkebunan atau untuk pemukiman penduduk, lebih-lebih penebangan pohon yang tidak legal (illegal logging)—untuk kepentingan ekonomisehingga hutan-hutan menjadi gundul; penangkapan ikan secara besar-besaran dengan menggunakan pukat harimau, atau dengan menggunakan media bom dengan meledakkan terumbu karang sebagai sarang ikan, bahkan penangkapan ikan yang tidak legal (illegal fishing) oleh nelayan asing; pengeboran minyak bumi maupun hasil tambang dengan melubangi permukaan bumi sedalam-dalamnya; atau berbagai pencemaran lingkungan darat, air dan udara akibat pembuangan limbah pabrik-pabrik, termasuk yang terkini terjadinya polusi udara di wilayah Riau yang berdampak hingga ke Singapura dan Malaysia. ${ }^{4}$ Beberapa aktifitas ini tergolong dalam tindakan perusakan lingkungan sehingga akan berdampak pada kehancuran lingkungan dan manusia itu sendiri.

Selain itu, perilaku hidup bersih dan menjaga kebersihan lingkungan sekitar di kalangan umat Islam masih

\footnotetext{
4 Terjadinya kabut asap dari Indonesia yang juga berdampak di Singapura menurut Hadi Daryanto, seorang pejabat Kementeraian Kehutanan RI mengatakan; bahwa timbulnya asap tersebut selain disebabkan oleh faktor pengaruh alam juga diakibatkan pembalakan dan pembakaran lahan sebagai metode yang murah untuk pembersihan lahan. Teknik ini tidak hanya digunakan oleh petani lokal, tetapi juga karyawan perusahaan minyak sawit, termasuk yang dimiliki oleh pengusaha Singapura dan Malaysia. Kami berharap pemerintah Malaysia dan Singapura juga memberi tahu pengusaha mereka untuk mengadopsi kebijakan layak, sehingga kita bisa mengatasi masalah ini bersama. Lihat Editor Erlangga Djumena, dalam Kompas.com, Asap di Singapura, Indonesia Tidak Akan Minta Maaf, Jumat, 2 Juni 2013/14.45WIB.
} 
sering terlihat terabaikan. Dalam arti, lingkungan tempat tinggal masyarakat seringkali tampak kotor, kumuh, dan menimbulkan bau yang tidak sedap. Pemandangan saluran got (selokan) yang mampet, meluber, dan akhirnya banjir menjadi hal yang banyak dijumpai di sekitar perkampungan warga terlebih pada saat musim hujan tiba.

Apabila diamati, mengapa terjadi pemandangan yang tidak elok di atas, salah satunya disebabkan oleh faktor perilaku masyarakat itu sendiri yang seringkali membuang sampah (limbah) secara sembarangan. Belum terdapat kesadaran masyarakat membuang sampah pada tempatnya, seperti membuang sampah sisa dapur ke sungai atau selokan, membuang sampah dari rumah dibuang (dilempar) ke pinggir jalan-jalan tertentu. Meskipun di pinggir jalan tersebut sudah terpasang papan nama yang secara tegas melarang membuang sampah di tempat tersebut oleh dinas kebersihan. Terkesan sikap masyarakat yang menentang dan mencemooh aturan yang berlaku. Sikap dan perilaku masyarakat yang demikian justru banyak diperlihatkan di negara-negara yang notabene masyarakatnya banyak beragama Islam. Tidak saja di Indonesia, India, negara-negara Islam di benua Afrika, tetapi bahkan di Mesir-yang merupakan pusat studi Islamlingkungan kotanya seringkali dipenuhi dengan sampah yang menggunung.

Perilaku dan tabiat masyarakat (khususnya masyarakat Islam) yang negatif di atas sesungguhnya merupakan suatu hal yang ironi. Apakah mereka tidak (belum) mengetahui ajaran Islam yang mengajarkan untuk selalu menjaga kebersihan, seperti bunyi kata mutiara al-nazhafat min al-imān (kebersihan adalah sebagian dari pertanda keimanan), ataukah mereka telah mengetahui ajaran Islam tersebut namun tidak peduli dengan ajaran tersebut bahkan menentangnya? 
Berpijak pada pemikiran di atas, penggalian konsep nilai-nilai kesadaran lingkungan melalui pendidikan dari dalam al-Quran perlu dilakukan, agar masyarakat mengetahui bagaimana seharusnya menjalankan kehidupannya sehari-hari menurut tuntunan Islam. Sehingga dengan begitu mereka mendapatkan kesehatan, kesejahteraan dan kebahagiaan dalam kehidupannya. Idealisme Islam menghendaki agar persoalan dikembalikan dan diselesaikan berdasarkan ajaran yang terkandung dalam al-Quran dan Sunah. ${ }^{5}$ Dengan begitu, al-Quran berfungsi sebagai pedoman bagi hidup dan kehidupan manusia. ${ }^{6}$

Kajian tentang kesadaran lingkungan telah dilakukan oleh pakar kesehatan dan lingkungan. Secara umum kajian tersebut didasarkan pada pendekatan ilmu profan yang sekularistik yang merupakan derivasi dari realitas rasional. Namun kajian tersebut tidak terkait dengan nilai-nilai profetis Islam (risâlah Islâmiyyah).

Implikasi pengembangan konsep kesadaran lingkungan sekuler di tengah masyarakat Islam dapat mengakibatkan timbulnya standar nilai ganda yang membingungkan. Di satu sisi, konsep kesadaran lingkungan sekuler tidak memberi tempat secara proporsional bagi nilai spiritual Islam, dan di sisi lain, masyarakat Islam mendambakan legitimasi spiritual

${ }^{5}$ QS. al-Nisâ' (4):59; QS. Ali 'Imrân (3):139; QS. al-Tawbah (9):40

${ }^{6}$ Al-Quran diturunkan membawa tiga maksud utama, yaitu sebagai petunjuk bagi jin dan manusia, sebagai tanda pendukung kebenaran Nabi saw., dan agar makhluk menyembah Tuhan dengan cara membacanya. Lihat Muhammad 'Abd al-'Azhîm al-Zarqânî, Manâhil al-'Irfân, (Kairo: 'Isâ al-Bâbî al-Halabî, 1972), Jilid I, h. 124. Lebih rinci tentang maksud diturunkannya Alquran, lihat Muhammad Rasyîd Ridhâ, al-Wahy al-Muhammadî, (Kairo: Maktabat al-Qâhirah, 1960), h. 126-8. Di samping itu Alquran disebut umm al-Kitâb, karena ia sebagai prototipe dari segala buku ilmu pengetahuan. Lihat Sayyed Hossein Nashr, Ideals and Realities of Islam, (London: Geoerge Allen and Unwin Ltd., 1972), 37 
Islam. ${ }^{7}$ Dengan demikian, perlu dirumuskan konsep internalisasi nilai-nilai kesadaran lingkungan melalui pendidikan yang menjunjung tinggi nilai-nilai spiritual agama.

Tulisan ini bertujuan untuk membangun sebuah konsep internalisasi nilai-nilai kesadaran lingkungan melalui pendidikan menurut al-Quran dengan berupaya menggali suatu penafsiran terhadap petunjuk-petunjuk al-Quran mengenai pengelolaan lingkungan. Tulisan ini diharapkan dapat membantu usaha-usaha peningkatan penghayatan dan pengamalan ajaran-ajaran serta nilai-nilai al-Quran, khususnya berkaitan dengan proses penanaman nilai-nilai kesadaran lingkungan bagi subjek didik di lembaga-lembaga pendidikan.

\section{B. Lingkungan Diciptakan Allah dengan Tujuan}

Alam semesta diciptakan oleh Allah SWT. bukanlah siasia belaka, atau sekedar ada dan asal ada serta tanpa tujuan. Tetapi Allah SWT. menciptakan lingkungan dengan tujuan tertentu untuk digunakan manusia dalam melanjutkan evolusinya hingga mencapai tujuan penciptaan. Allah SWT. menegaskan dalam QS. Shād (38): 27;

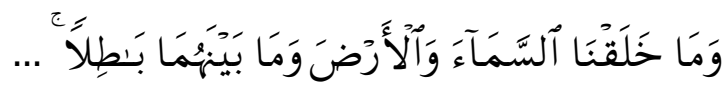

"Dan Kami tidak menciptakan langit dan bumi dan apa yang ada antara keduanya tanpa hikmah."

Ayat di atas menyiratkan kepada manusia agar dalam melaksanakan tugasnya sebagai khalifah Tuhan memilki sikap yang bijak dalam mengelola lingkungan. Dalam arti manusia tidak melakukan perusakan dan pencemaran sehingga mengganggu ekosistem lingkungan. Karena lingkungan

${ }^{7}$ Mujiyono Abdillah, Agama Ramah Lingkungan; Perspektif Al-Qur'an, (Jakarta: Paramadina, 2001), 10 
diciptakan Allah SWT. dengan hikmah tertentu selain untuk memenuhi kebutuhan manusia, juga sebagai keseimbangan dan keserasian alam. Ketika manusia sadar memelihara lingkungan, maka akan tercipta kelestarian.

Lebih lanjut, kehidupan antar makhluk Tuhan saling terkait. Bila terjadi gangguan yang luar biasa terhadap salah satunya, maka makhluk yang berada dalam lingkungan hidup tersebut ikut terganggu pula. ${ }^{8}$ Dengan demikian ayat di atas memberikan pendidikan kepada umat manusia agar senantiasa memiliki sikap bijak terhadap lingkungan dan senantiasa sadar untuk tidak menyia-nyiakan lingkungan dengan merusaknya.

\section{Upaya Internalisasi Nilai-nilai Kesadaran Lingkungan}

Manusia adalah ciptaan Allah SWT. yang mempunyai kedudukan sangat tinggi, bahkan malaikat pun diperintahkan untuk bersujud (menghormat) kepadanya. Melalui informasi yang diajarkan oleh Allah SWT. kepada Adam, manusia mampu secara potensial untuk mengetahui hukum-hukum alam, ${ }^{9}$ dan melalui penundukan Allah SWT. terhadap alam raya, manusia dapat memanfaatkan seluruh jagat raya. ${ }^{10}$ Semua ini bertujuan untuk menyukseskan tugas kekhalifahan manusia di muka bumi dalam rangka pengabdiannya kepada Allah SWT., karena Dia tidak menciptakan jin dan manusia kecuali untuk menyembah kepada-Nya. ${ }^{11}$

Upaya-upaya internalisasi nilai-nilai kesadaran lingkungan melalui pendidikan dapat digali informasinya dengan memperhatikan ayat-ayat al-Quran yang terkait. Upaya-

\footnotetext{
${ }^{8}$ M. Quraish Shihab, Membumikan Al-Quran, (Bandung: Mizan, 1997), 295

${ }^{9}$ QS. al-Baqarah (2/87):31

${ }^{10}$ QS. al-Jatsiyah (45/65):13

11 QS. al-Dzariyat (51/67): 56

Jurnal Pendidikan Agama Islam 
upaya tersebut dapat digali melalui beberapa hal sebagai berikut.

\section{Peningkatan Pengetahuan dan Ketrampilan}

Kajian difokuskan pada informasi yang dapat digali dari QS. al-Isra'(17/50): 84;

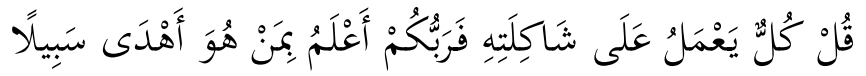

"Katakanlah: "Tiap-tiap orang berbuat menurut keadaannya masing-masing". Maka Tuhanmu lebih mengetahui siapa yang lebih benar jalannya. ${ }^{12}$

Kata شَاكِلة dalam ayat di atas pada mulanya digunakan untuk "cabang pada suatu jalan". Thāhir ibn 'Asyūr memahami kata ini dengan makna "jalan" atau "kebiasaan" yang dilakukan oleh seseorang. Sayyid Quthub memahaminya dalam arti "cara" dan "kecenderungan". Maksud makna ini benar. Ayat ini menunjukkan bahwa setiap manusia mempunyai kecenderungan, potensi, dan pembawaan yang menjadi pendorong aktivitasnya.

Lebih lanjut, ada empat tipe manusia. Pertama, ada yang memiliki kecenderungan beribadah; kedua, ada lagi yang senang meneliti dan tekun belajar; ketiga, ada yang pekerja keras; keempat, ada yang seniman. Semua berbeda penekanannya. Di sisi lain ada manusia yang pemberani dan ada yang penakut. Ada yang dermawan dan ada pula yang kikir. Ada yang pandai berterima kasih, ada juga yang mengingkari jasa. Dua makna di atas (yang mempunyai nilai

12 Departemen Agama RI., Al Qur'an dan Terjemahnya, (Jakarta: Bumi Restu, 1975), 437 
positif dan negatif) dapat ditampung oleh kata 13 نََّاكِلَة. Manusia masing-masing melakukan apa yang dianggapnya baik. Allah SWT. dan Rasul-Nya tidak akan memaksa. Allah SWT. hanya mengingatkan bahwa Dia lebih mengetahui siapa yang berbuat baik dan siapa pula yang sesat. Dia memberi masing-masing balasan yang sesuai. ${ }^{14}$

QS. al-Isra' (17/50): 84 di atas dapat dikaitkan dengan QS. al-Rūm (30/84): 41 mengenai terjadinya kerusakan di muka bumi. Maksud pengkaitan di sini adalah untuk melihat adanya relasi antara kualitas pengetahuan dan ketrampilan manusia yang mendayagunakan ilmunya dengan kerusakan yang terjadi pada lingkungan. Ini berarti kemajuan yang diperoleh manusia sebagaimana terlihat dewasa ini tergantung pada ilmu pengetahuan dan teknologi yang mereka miliki. Langkah yang harus dipertimbangkan adalah meningkatkan pengetahuan umat manusia guna memacu prestasi mereka dalam mengolah lingkungan. ${ }^{15}$

Dalam pada itu, peningkatan pengetahuan dan ketrampilan dapat dilakukan melalui pendidikan terhadap masyarakat. Keberhasilan pendidikan terhadap mereka mempunyai peranan penting dalam menunjang keberhasilan pengelolaan lingkungan. Pendidikan merupakan wadah utama peningkatan kualitas sumber daya manusia. Selain itu harus disadari bahwa keberhasilan pembangunan lingkungan harus didukung oleh kemampuan masyarakat dalam menguasai dan menerapkan teknologi, yang hanya dapat dicapai melalui pendidikan yang bermutu dan relevan.

13 M. Quraish Shihab, Tafsir al-Mishbah, (Jakarta: Lentera Hati, 2000), Vol. VII, 536

${ }^{14}$ M. Quraish Shihab, Tafsir al-Mishbah ..., Vol. VII, 537

${ }^{15}$ Abd. Muin Salim, Pokok-pokok Pikiran tentang Laut dan Kehidupan Bahari dalam Alquran, makalah seminar IAIN Alauddin Ujung Pandang, 7 
Oleh karena itu, untuk menunjang keberhasilan pengelolaan lingkungan, selain pendidikan formal, masyarakat harus mendapat perhatian yang sungguhsungguh, sekurang-kurangnya wajib belajar di kalangan masyarakat harus disukseskan secara optimal, juga ditambahkan kurikulum khusus yang terkait upaya internalisasi nilai-nilai kesadaran lingkungan. Kurangnya perhatian kurikulum klasik terhadap materi pendidikan kesadaran lingkungan perlu dievaluasi. Perhatian ulama dan ilmuwan masa lalu hanya banyak berkisar pada persoalan internaslisasi akhlak terhadap Tuhan dan sesama manusia, dan perlu dilengkapi dengan perhatian yang memadai terhadap ajaran berakhlak terhadap alam semesta dan lingkungan.

Salah satu permasalahan yang mendasar adalah masalah pemahaman dan aspirasi pendidikan, ditambah dengan masalah tingkat ekonomi masyarakat terutama mereka yang rendah tingkat ekonominya, serta masalah geografis. ${ }^{16}$ Masalah pemahaman masyarakat terhadap arti dan manfaat pendidikan merupakan masalah mendasar yang sangat serius, karena ketidaktahuan masyarakat terhadap arti dan manfaat pendidikan menyebabkan mereka menolak semua upaya pendidikan yang dilaksanakan. Padahal upaya-upaya tersebut demi peningkatan pendidikan anak-anak mereka yang pada akhirnya akan bermuara pada peningkatan kualitas sumber daya manusia, pada gilirannya akan meningkatkan kesejahteraan dan harkat serta martabat mereka sendiri. Ketidakpahaman tersebut juga mengakibatkan rendahnya aspirasi terhadap pendidikan anak. Padahal aspirasi pendidikan yang rendah akan

16 Djaali, Pembinaan Masyarakat Bahari; Suatu Tinjauan Pendidikan, makalah seminar IAIN Alauddin Ujung Pandang, 5-6 
menghambat upaya pendidikan, karena dengan aspirasi yang rendah itu menyebabkan mereka tidak bersedia bersusah payah untuk mencapai tingkat pendidikan tertentu, apalagi jika dituntut untuk berkorban demi pendidikan.

Sebagai ilustrasi problematika pendidikan di kalangan masyarakat nelayan; dengan tingkat ekonomi yang rendah, sangat sulit bagi masyarakat untuk mencapai tingkat pendidikan yang memadai, apalagi dengan tingkat pemahaman dan aspirasi yang rendah terhadap pendidikan anak, ditambah lagi dengan nilai anak di masyarakat nelayan lebih dimaksudkan sebagai tenaga kerja yang ditujukan untuk membantu mengatasi masalah ekonomi keluarga, sehingga angka partisipasi pendidikan anak usia sekolah menjadi sangat rendah. Selain itu, masalah geografis menyebabkan masyarakat nelayan sulit terjangkau oleh informasi dan fasilitas pendidikan. Hal ini menambah rumitnya permasalahan pendidikan masyarakat bahari. ${ }^{17}$

Semua permasalahan tersebut di atas harus mendapat perhatian dan upaya pemecahan yang sungguh-sungguh, karena bagaimanapun sulitnya keadaan dan permasalahan pendidikan masyarakat bahari, program wajib belajar sembilan tahun sebagaimana yang sudah dimulai sejak tanggal 2 Mei 1994, harus terus berjalan di berbagai kelompok masyarakat, termasuk masyarakat bahari. Bahkan kita tidak ingin hanya sekedar melaksanakan wajib belajar, tetapi lebih dari itu, kita harus membina pendidikan formal masyarakat bahari untuk memberikan pengetahuan dasar sebagai penunjang bagi peningkatan kemampuan dalam menguasai dan menerapkan teknologi, khususnya teknologi budidaya dan kelautan, yang sangat dibutuhkan untuk

${ }_{17}$ Djaali, Pembinaan Masyarakat Bahari ..., 6 
meningkatkan kesejahteraan masyarakat bahari melalui peningkatan daya guna dan hasil guna sumber daya laut. ${ }^{18}$

Dalam upaya pemecahan masalah-masalah pendidikan, khususnya pendidikan formal di kalangan masyarakat bahari seperti telah dikemukakan, pertama-tama ita harus menentukan prioritas yang didasarkan atas kelayakan. Dari tiga arah kebijakan pendidikan, yaitu pemerataan kesempatan belajar, peningkatan relevansi pendidikan, dan peningkatan mutu pendidikan, ${ }^{19}$ maka bagi masyarakat bahari hendaknya prioritas diarahkan kepada perluasan kesempatan belajar dan peningkatan relevansi pendidikan. Kedua hal ini akan saling terkait, karena di satu sisi peningkatan relevansi pendidikan yang dilakukan secara kongkret akan dapat meningkatkan kesadaran dan pemahaman masyarakat terhadap arti dan manfaat pendidikan, sehingga pada gilirannya akan mendukung upaya menyukseskan program wajib belajar sebagai paket dari upaya perluasan kesempatan belajar. Sedang di sisi lain, keberhasilan wajib belajar akan mendukung peningkatan relevansi pendidikan dengan kesadaran lingkungan.

Peningkatan relevansi pendidikan seperti ini diharapkan dapat mencapai tiga sasaran, (1) meningkatkan produktivitas sumber daya manusia masyarakat bahari, (2) meningkatkan kesadaran dan pemahaman masyarakat bahari akan arti dan manfaat pendidikan bagi kesejahteraan mereka, dan (3) meningkatkan kecintaan terhadap sumber daya alam yang ada di sekitar mereka, karena merasakan manfaatnya bagi peningkatan kesejahteraan, sehingga pada gilirannya akan menumbuhkan kesadaran berwawasan lingkungan. Sasaran yang terakhir ini sangat penting,

18 Djaali, Pembinaan Masyarakat Bahari ..., 7

19 Undang-undang No. 2 tentang "Sistem Pendidikan Nasional," tahun 1989 
karena potensi sumber daya laut yang tersedia yang berada dalam suatu ekosistem di laut harus dimanfaatkan secara optimal, tetapi harus tetap memelihara kelestariannya untuk mendukung pembangunan kelautan. ${ }^{20}$

Untuk mendukung upaya-upaya yang telah dikemukakan, sudah saatnya paket-paket pendidikan dan keterampilan kesadaran lingkungan dimasukkan ke dalam kurikulum muatan lokal untuk sekolah-sekolah, mulai dari SD sampai SMA sesuai dengan tingkat kesukaran dari paketpaket pendidikan dan keterampilan yang akan diberikan tersebut. Oleh karena itu, untuk menunjang keberhasilan pembinaan pendidikan formal masyarakat, harus dilakukan upaya nyata seperti telah dikemukakan. Selain itu, mengingat potensi masyarakat yang demikian besar dalam mendukung keberhasilan pembangunan, pemerintah harus mempunyai komitmen yang kuat untuk memberikan perhatian dan prioritas terhadap pemberian dukungan fasilitas pendidikan yang memadai bagi masyarakat bahari.

QS. al-Isra' (17/50): 84, sebagaimana dikemukakan di atas, menegaskan perintah agar manusia bekerja berdasarkan pengetahuan, bahkan mengisyaratkan pentingnya ketrampilan (pengetahuan praktis). ${ }^{21}$ Dengan demikian al-Quran menegaskan bahwa bekerja yang dikehendaki ialah bekerja yang sesuai dengan bakat kemampuan yang dimiliki dan bukan hanya semata-mata berdasarkan pengetahuan teoritis.

Implikasi dari ayat di atas adalah perlunya peningkatan pengetahuan masyarakat dalam mengelola

20 Djaali, Pembinaan Masyarakat Bahari ..., 8

${ }^{21}$ Lihat Muhammad ibn 'Ali Muhammad al-Syaukānī, Fath al-Qadīr, (Beirut: Dār al-Fikr, tth.), Juz III, 253-254. Lihat pula Muhammad Nawawī al-Jāwī, Marāh Labid, (Beirut: Dār al-Fikr), Jilid I, 487 
lingkungan. Terlebih lagi pemberian ketrampilan yang relevan, agar mereka dapat meningkatkan kemampuan dalam mengolah lingkungannya secara efektif dan efisien, atau berdaya dan berhasil guna. Sebagai contoh, terdapat ayat al-Quran sendiri yang mengisyaratkan untuk melakukan kegiatan eksplorasi potensi laut yang tentunya dapat dikembangkan dengan berbagai variasi yang kini sudah sangat berkembang.

\section{Pemberian Bantuan}

Dalam sub ini, kajian difokuskan kepada informasi yang dapat digali dari QS. al-Mā'idah (5/112): 3;

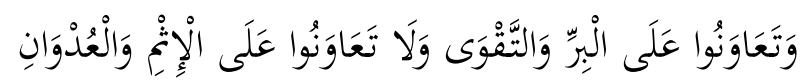

"Dan tolong-menolonglah kamu dalam (mengerjakan) kebajikan dan takwa, dan jangan tolong-menolong dalam berbuat dosa dan pelanggaran."22

Ayat di atas mengisyaratkan pentingnya kerja sama dan pemberian bantuan kepada pihak-pihak yang membutuhkan. Melihat kehidupan sebagian masyarakat yang secara umum memang belum menggembirakan, bahkan masih jauh di bawah garis kemiskinan, maka berdasar kenyataan tersebut berarti mereka memerlukan dukungan materiil melalui bantuan atau kerja sama, yang memungkinkan pelaksanaan pembangunan terhadap masyarakat mulai dari level bawah.

Bantuan dan kerja sama sesungguhnya telah banyak dilakukan oleh kelompok-kelompok tertentu, baik organisasi sosial maupun keagamaan, bahkan secara individual. Akan tetapi tentu saja hal ini belum memadai terutama jika

22 Departemen Agama RI., Al Qur'an ..., 157 
bantuan dan kerja sama tersebut tidak disusun secara terencana dan terkordinasi dengan baik. Lebih-lebih lagi jika pelaksanaannya ditumpangi oleh kepentingan pihak-pihak tertentu untuk mencari keuntungan pribadi.

Sebagai ilustrasi, masyarakat pesisir dan pulau-pulau membutuhkan modal kerja bagi para nelayan, disamping ketrampilan pengolahan laut. Tentu tidak ada salahnya kalau program yang dilakukan terhadap masyarakat daratan diperlakukan pula terhadap masyarakat pesisir. Misalnya, dengan sistem orang tua angkat (orang tua asuh) secara terorganisir.

Berkaitan dengan kerja sama ini, ada baiknya diperhatikan pernyataan seorang Muslim ketika mendirikan shalat "iyyāka na'budu" (hanya kepada-Mu kami beribadah) yang dikemukakan dalam bentuk jamak. Hal ini menunjukkan bahwa Islam sangat mendorong kerja sama dalam melaksanakan ibadah, termasuk dalam melaksanakan kerja. Oleh karena itu, shalat berjamaah lebih utama daripada shalat sendirian, dan Nabi SAW. sendiri selalu menganjurkan bahkan mempraktikkan kerja sama dalam berbagai aktifitasnya. Suatu ketika Nabi SAW. dan para sahabatnya merasa lapar, dan mereka sepakat untuk makan bersama. Salah seorang di antara mereka mengatakan: "Saya mencari kambingnya." Yang lain berkata: "Saya yang akan menyembelihnya." Yang ketiga berkata: "Saya yang akan mengulitinya." Yang keempat berkata: "Saya yang akan memasaknya." Sedangkan Nabi SAW. bersabda: "Saya yang mengumpulkan kayu bakarnya."23 Demikianlah budaya kerja sama yang dipraktikkan Nabi SAW. dan para sahabatnya yang seharusnya diteladani oleh umatnya.

${ }^{23}$ Muslim ibn al-Hajjāj Ab- al-Husayn al-Qusyairī al-Naisābūrī, Shahīh Muslim, Juz I, (Beirut: Dār Ihyā' al-Turāts al-'Arabī, t.th), 451 


\section{Tidak Boros dalam Memanfaatkan Sumber Daya Alam}

Termasuk upaya menanamkan nilai kesadaran lingkungan adalah perilaku hemat dalam menggunakan sumber daya alam. Prinsip ini didasarkan pada QS. al-Isrā' (17/50): 26-27;

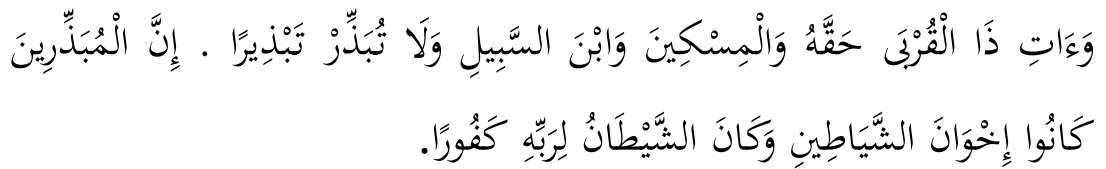

"Dan berikanlah kepada keluarga-keluarga yang dekat akan haknya, kepada orang miskin dan orang yang dalam perjalanan; dan janganlah kamu menghambur-hamburkan (hartamu) secara boros. Sesungguhnya pemboros-pemboros itu adalah saudara-saudara setan dan setan itu adalah sangat ingkar kepada Tuhannya."24

Dalam Hadis Nabi SAW. juga dinyatakan:

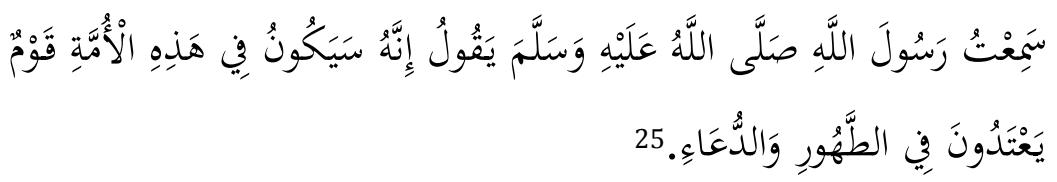

"Dari Abu Na'amah namanya Qayis bin Abayah, bahwa Abdullah bin Mughaffal (berkata)..., saya mendengar Rasulullah SAW. bersabda: Sesungguhnya di antara umat ini akan ada suatu kaum yang berlebih-lebihan dalam bersuci dan berdoa. ${ }^{26}$

Termasuk berlaku boros di sini adalah memakai air secara berlebihan ketika berwudu, meskipun di tepi pantai

\footnotetext{
24 Departemen Agama RI., Al Qur'an ..., 428

25 Abū Dāwūd, Sunan Abī Dāwūd, kitāb al-Thahārah, bāb al-isyrāffi al-mā', Hadis nomor 96, dalam Mawsū'ah al-Hadìt al-Syarif, versi 2.0, CD ROM, (Mesir: Syirkah Sakhr li Baramij al-Hasub, 1991)

26 Terjemahan penulis
} 
atau di sungai besar, sebagaimana Hadis Rasulullah SAW. kepada Sa'ad yang diriwayatkan oleh Ahmad dan Ibn Mājah melalui jalur 'Abdullāh bin 'Amr.27 Berkaitan pula dengan hal ini ditemukan beberapa Hadis tentang ukuran minimal air yang digunakan dalam bersuci dan mandi, antara lain sabda Nabi SAW.:

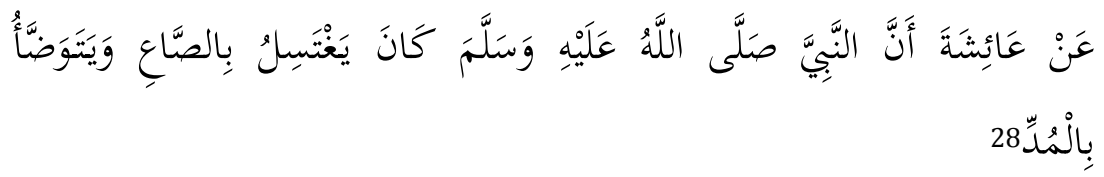

"Dari Aisyah r.a. bahwa Nabi saw. mandi dengan air sebanyak satu sha' (gantang) ${ }^{29}$ dan berwudu dengan air sebanyak satu mud." 30

Hadis-Hadis ini memperlihatkan bahwa ajaran Islam sangat mengutamakan penggunaan air secara efisien (hemat), sekalipun dalam keperluan yang menyangkut ibadah.

Selain dalam berwudlu dan mandi (biasa) seperti dikemukakan di atas, terdapat pula tuntunan Hadis mengenai penggunaan air ketika mandi junub, misalnya:

27 Muhammad Syams al-Haq al-'Adzīm Abadī Abū Thayyib, 'Aun al-Ma'būd, (Beirut: Dār al-Kutub al-'Ilmiyyah, 1415 H.), Jilid I, 170

28 Abū Dāwūd, Sunan Abī Dāwūd, kitab al-Thahārah, Hadis nomor 92 dalam Mawū-'ah al-Hadīts.

${ }^{29}$ Satu Sha' (gantang) = 3,363 liter (Hanafiah); atau 2,748 liter (Hanafiah); atau 3261,5 gram (Hanafiah); dan 2172 gram menurut lainnya. Lihat Muhammad Rawwās Qal'ahjī dan Hamīd Shādiq Qunaibī, Mu'jam Lughah al-Fuqaha', (Beirut: Dār al-Nafāis, 1988), 270

30 Satu $m u d=1,032$ liter atau 815,39 gram (Hanafiah); dan 0,687 liter atau 543 gram menurut lainnya. Lihat Muhammad Rawwās Qal'ahjī dan Hamīd Shādiq Qunaibī, Mu'jam Lughah ..., 417 


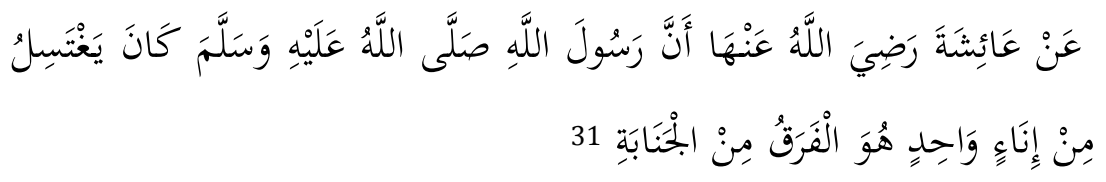

"Dari Aisyah r.a., bahwasanya Rasulullah saw. biasa mandi junub dengan air dari satu bejana, yaitu sebanyak satu faraq."32

Jadi Hadis-Hadis ini tidak hanya menghendaki penggunaan air secara efisien, tetapi secara lebih gamblang memberikan batas minimal dalam ukuran penggunaannya. Hal ini lebih mempertegas bahwa hukum Islam menegakkan larangan berlaku boros dalam memanfaatkan sumber daya alam-dalam hal ini air-bukanlah sekedar slogan verbal, tetapi langsung dipraktikkan dalam kehidupan nyata dan hal tersebut dicontohkan langsung oleh Rasulullah SAW.

Jika seseorang mengambil atau menggunakan terlalu banyak air melebihi porsinya, maka pasti ada orang lain yang tidak mendapatkan. Yang bersangkutan menganiaya dirinya sendiri, karena minum terlalu banyak. Di samping ia juga menganiaya sumber daya alam (air), karena tidak memfungsikannya sesuai dengan tujuan penciptaannya, dan sekaligus menganiaya orang lain, karena mengambil haknya.

Prinsip ini sangat terkait dengan pemborosan dan keserakahan manusia moderen-yang memang mengembangkan pola konsumtif pada taraf yang tak terkendali-yang pada gilirannya mengakibatkan terjadinya krisis lingkungan. Demikian pula berkaitan dengan sumber daya kelautan, bila penangkapan ikan dilakukan secara tak

\footnotetext{
${ }^{31} \mathrm{Abu}$ Dāwūd, Sunan Abī Dāwūd, kitab al-Thahārah, Hadis nomor 228 dalam Mawsū'ah al-Hadìts.

${ }^{32}$ Satu faraq $=10,086$ liter menurut Hanafiah, dan 8,244 liter menurut selain Hanafiah. Lihat Mu'jam al-Lughah ..., 344
} 
terkendali dan sewenang-wenang; baik ikan-ikan besar maupun kecil, menggunakan zat-zat kimia maupun bahanbahan peledak, maka dalam satu waktu tertentu, potensi perikanan di wilayah tangkap tertentu akan habis (overfishing) dan berdampak pada kerugian yang dialami manusia sendiri (nelayan).

\section{Sanksi bagi Perusak Lingkungan}

Dalam upaya menegakkan nilai-nilai pendidikan kesadaran lingkungan, al-Quran menegaskan sanksi yang diberikan kepada para perusak lingkungan. Hal ini disampaikan al-Quran guna menghindarkan manusia untuk melanggarnya. Allah SWT. menegaskan dalam QS. al-Mā'idah (5/112): 33-34;

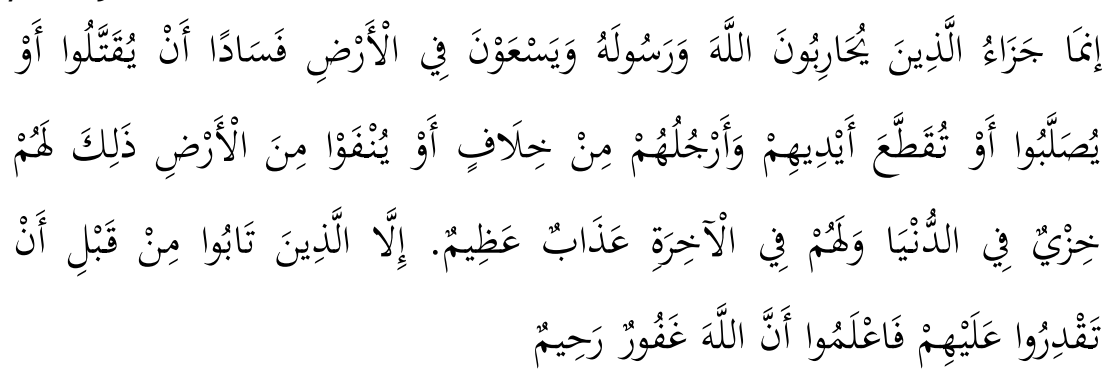

"Sesungguhnya pembalasan terhadap orang-orang yang memerangi Allah dan Rasul-Nya dan membuat kerusakan di muka bumi, hanyalah mereka dibunuh atau disalib, atau dipotong tangan dan kaki mereka dengan bertimbal balik, atau dibuang dari negeri (tempat kediamannya). Yang demikian itu (sebagai) suatu penghinaan untuk mereka di dunia, dan di akhirat mereka beroleh siksaan yang besar, kecuali orang-orang yang tobat (di antara mereka) sebelum kamu dapat menguasai (menangkap) mereka; maka 
ketahuilah bahwasanya Allah Maha Pengampun lagi Maha Penyayang."33

Berkaitan dengan pengelolaan lingkungan, aktifitas ini tidak boleh dilakukan secara eksploitatif, hanya menguras sumber daya alam dan mencemari lingkungan, sebab akan menimbulkan kerusakan. Allah SWT. menyatakan kemurkaanNya kepada para pelaku perusakan di muka bumi (alam), agar mereka ditangkap untuk dibunuh dan disalib, supaya kejahatan tidak merajalela.

Ayat di atas secara tegas menyatakan hukuman bagi orang-orang yang bertindak melampaui batas; melanggar dengan angkuh terhadap ketentuan-ketentuan Allah SWT. dan Rasul-Nya-yang dibahasakan oleh al-Quran dengan frasa بَأَذِينَ

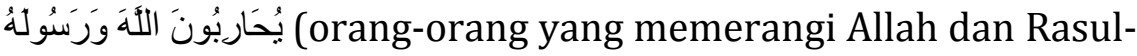
Nya)—dan terhadap orang-orang yang berkeliaran membuat kerusakan di muka bumi-yang diungkapkan al-Quran dengan

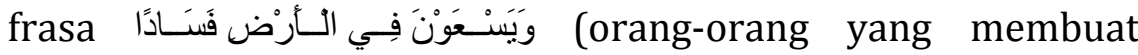
kerusakan di muka bumi)-yakni dengan melakukan pembunuhan, perampokan, pencurian dengan menakut-nakuti masyarakat, hanyalah mereka dibunuh tanpa ampun jika mereka membunuh tanpa mengambil harta; atau disalib setelah dibunuh jika mereka merampok dan membunuh, untuk menjadi pelajaran bagi yang lain sekaligus menentramkan masyarakat bahwa penjahat telah tiada, atau dipotong tangan kanan mereka karena merampas harta tanpa membunuh, dan juga dipotong kaki mereka dengan bertimbal balik, karena ia telah menimbulkan rasa takut dalam masyarakat, atau dibuang dari negeri tempat kediamannya, yakni dipenjarakan agar tidak menakuti masyarakat, jika ia tidak merampok harta.

33 Departemen Agama RI., Al Qur'an ..., 164 
Hukuman demikian dijatuhkan kepada mereka sebagai penghinaan di dunia, sehingga orang lain yang bermaksud jahat akan tercegah melakukan hal serupa. Di samping hukuman di dunia, mereka juga akan menanggung hukuman di akhirat, bila mereka tidak bertobat. Jika mereka bertobat sebelum tertangkap, maka Allah SWT. Maha Pengampun lagi Maha Penyayang. Karena itu hak Allah SWT. untuk menjatuhkan sanksi akan dicabut-Nya, tetapi hak manusia yang diambil oleh para penjahat yang bertobat itu harus dikembalikan atau dimintakan kerelaan pemiliknya. ${ }^{34}$ Ancaman-ancaman di atas tampaknya sangat relevan jika ditujukan pula kepada para perusak lingkungan, baik di darat maupun di laut, seperti para pelaku tindak illegal logging (pencurian kayu) di hutan, para pencuri ikan yang dilakukan nelayan asing, serta pencurian pasir laut di perairan laut Indonesia, dan lain-lain.

Ancaman dengan hukum bunuh dan disalib tersebut cukup masuk akal, oleh karena tindak kejahatan mereka seperti disebutkan di atas pada dasarnya merusak ekosistem lingkungan di darat dan di laut, di mana hal ini dapat membahayakan kelestarian lingkungan yang pada akhirnya dapat mendatangkan bencana alam. Apabila bencana alam terjadi, maka ia mengakibatkan terjadinya banyak korban jiwa. Dengan begitu, sesungguhnya para penjarah, pencuri dan perampok sumber daya alamlah yang secara tidak langsung, menyebabkan umat manusia tewas menjadi korban bencana alam. Dengan demikian, para pelaku kejahatan di sini patut dihukum bunuh dan disalib, jika mereka tidak mau bertobat dan mengembalikan sumber daya alam yang telah dirampoknya, serta memulihkan ekosistem yang telah terganggu sehingga kembali seimbang.

\footnotetext{
34 M. Quraish Shihab, Tafsir al-Mishbah ..., Vol. III, 83-84 
Dalam ayat sebelumnya, QS. al-Mā'idah (5/112): 32, ditegaskan bahwa seseorang yang membunuh orang lain secara zalim (bukan karena melaksanakan hukuman qishash kepada yang dibunuh atau yang dihukum bunuh telah membuat kerusakan di muka bumi) pada hakikatnya seolah-olah ia membunuh umat manusia seluruhnya;

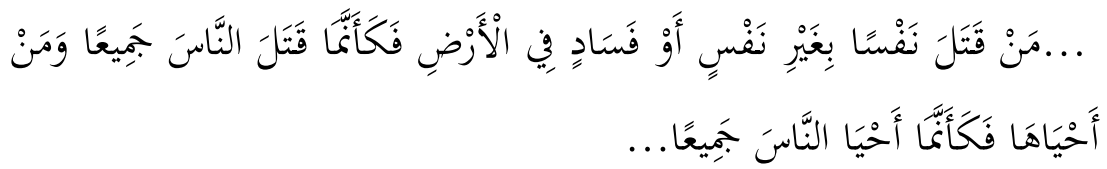

“... barangsiapa yang membunuh seorang manusia, bukan karena orang itu (membunuh) orang lain, atau bukan karena membuat kerusakan di muka bumi, maka seakan-akan dia telah membunuh manusia seluruhnya. Dan barangsiapa yang memelihara kehidupan seorang manusia, maka seolah-olah dia telah memelihara kehidupan manusia semuanya ...."35

Dapat dipahami mengapa ayat di atas menegaskan ketentuan sedemikian rupa, oleh karena ajaran al-Quran sangat menghormati, memuliakan, dan memandang suci kehidupan umat manusia. Sehingga seseorang yang membunuh orang lain, seolah-olah ia telah membunuh umat manusia seluruhnya. Sebaliknya, seseorang yang memelihara tangannya untuk tidak membunuh orang lain, seolah-olah ia membiarkan hidup umat manusia secara keseluruhan. Sesungguhnya kehidupan seorang manusia merefleksikan kehidupan umat manusia seluruhnya, karena pada dasarnya, mereka diciptakan berasal dari satu jiwa (nafs wāhidah). ${ }^{36}$ Allah SWT. memandang bahwa membunuh

35 Departemen Agama RI., Al Qur'an ..., 164

36 QS. al-Nisā' (4/92): 1. Pada setiap jiwa manusia terdapat 'tiupan suci' di mana seluruh umat manusia berasal. Maka membunuh seorang manusia, hakikatnya memadamkan 'nyala api suci' yang merupakan asal kehidupan. 
seseorang itu sebagai membunuh manusia seluruhnya, karena seseorang itu adalah anggota masyarakat, dan karena membunuh seseorang berarti juga membunuh keturunannya. Dengan demikian, kembali pada bahasan semula, dalam ayat ini terdapat indikasi bahwa membuat kerusakan lingkungan membawa konsekwensi adanya hukum bunuh bagi pelakunya.

Dari uraian di atas dapat dipahami bagaimana konsep al-Quran mengisyaratkan nilai-nilai kesadaran lingkungan melalui pendidikan bagi umat manusia. Nilai-nilai ini perlu diterapkan guna mencapai kesejahteraan mereka sendiri dalam menjalankan kehidupannya di bumi ini. Dapat pula dikemukakan bahwa ayat-ayat di atas mengisyaratkan adanya potensi perkembangan dalam masyarakat untuk mencapai taraf kehidupan yang lebih baik keadaannya, untuk itu perlu pendidikan dan pembinaan kesadaran lingkungan.

\section{E. Penutup}

Setelah menelaah ayat-ayat al-Quran yang berkaitan dengan internalisasi nilai-nilai kesadaran lingkungan melalui pendidikan, maka dapat disimpulkan bahwa lingkungan merupakan anugerah Allah SWT. yang diperuntukkan bagi umat manusia. Penganugerahan ini memberikan konsekwensi bagi manusia, sebagai khalifah Allah di muka Bumi, memiliki hak pengelolaan guna mengambil manfaat darinya, di samping memiliki tanggung jawab (kewajiban) untuk melakukan upaya konservasinya guna menjaga keseimbangan ekologi. Upaya pelestarian tersebut tidak saja dapat memelihara kelangsungan ekologi lingkungan, tetapi juga kelangsungan kehidupan

Lihat 'Abd al-Karīm al-Khathīb, al-Tafsìr al-Qur'ānī li al-Qur'ān, (Beirut: Dār alFikr al-'Arabī, t.th.), Jilid III, 1081-1082 
manusia itu sendiri dalam jangka panjang, khususnya generasi mendatang yang juga memiliki hak terhadap anugerah ini.

Pengelolaan lingkungan harus berpijak pada prinsipprinsip dan nilai-nilai al-Quran, yaitu; (1) seluruh alam raya beserta isinya adalah milik Tuhan dan ciptaan-Nya; (2) seluruh isi alam diperuntukkan bagi manusia dan makhluk hidup lainnya; (3) alam ini ditundukkan agar dapat dikelola oleh manusia; (4) manusia dititipi amanah oleh Tuhan untuk mengelola lingkungan; (5) sebagai khalifah, manusia bertugas mengantarkan lingkungan untuk mencapai tujuan penciptaannya; (6) pemborosan harus dicegah; (7) kerusakan lingkungan adalah akibat perbuatan manusia, dan oleh karena itu manusia harus bertanggungjawab di dunia dan di akhirat; dan (8) kasih sayang manusia kepada seluruh makhluk bermakna menghargai seluruh makhluk dan memperlakukannya dengan baik.

Untuk menanamkan nilai-nilai kesadaran lingkungan berdasarkan spiritualitas Islam di atas perlu diupayakan melalui proses pendidikan yang sistematis dan sinergis dengan memberikan perhatian khusus berupa pembentukan kurikulum pendidikan yang bernuansa kesadaran pelestarian lingkungan bagi anak didik sejak dini. Dengan upaya ini diharapkan terwujudnya kelestarian lingkungan hidup yang semakin nyata dan membawa kepada kesejahteraan bersama. 


\section{DAFTAR PUSTAKA}

'Abd al-Karīm al-Khathīb, al-Tafsīr al-Qur'ānī li al-Qur'ān, (Beirut: Dār al-Fikr al-'Arabī, t.th.), Jilid III.

Abū Dāwūd, Sunan Abī Dāwūd, kitāb al-Thahārah, bāb al-isyrāf fi al-mā', Hadis nomor 96, dalam Mawsū'ah al-Hadìt alSyarif, versi 2.0, CD ROM, (Mesir: Syirkah Sakhr li Baramij al-Hasub, 1991)

Abd. Muin Salim, Pokok-pokok Pikiran tentang Laut dan Kehidupan Bahari dalam Alquran, makalah seminar IAIN Alauddin Ujung Pandang.

Departemen Agama R.I., Al Qur'an dan Terjemahnya, (Jakarta: Bumi Restu, 1975/1976)

Erlangga Djumena (Editor), dalam Kompas.com, Asap di Singapura, Indonesia Tidak Akan Minta Maaf, Jumat, 2 Juni 2013/14. 45WIB.

Djaali, Pembinaan Masyarakat Bahari; Suatu Tinjauan Pendidikan, makalah seminar IAIN Alauddin Ujung Pandang.

Mujiyono Abdillah, Agama Ramah Lingkungan; Perspektif AlQur'an, (Jakarta: Paramadina, 2001)

M. Quraish Shihab, Membumikan Al-Quran, (Bandung: Mizan, 1997)

M. Quraish Shihab, Tafsir al-Mishbah, (Jakarta: Lentera Hati, 2000), Vol. VII.

Muhammad 'Abd al-'Azhîm al-Zarqânî, Manâhil al-'Irfân, (Kairo: 'Isâ al-Bâbî al-Halabî, 1972), Jilid I

Muhammad Rasyîd Ridhâ, al-Wahy al-Muhammadî, (Kairo: Maktabat al-Qâhirah, 1960)

Muhammad Syams al-Haq al-'Adzīm Abadī Abū Thayyib, 'Aun alMa'būd, (Beirut: Dār al-Kutub al-'Ilmiyyah, 1415 H.), Jilid I. 
Muhammad Rawwās Qal'ahjī dan Hamīd Shādiq Qunaibī, Mu'jam Lughah al-Fuqaha', (Beirut: Dār al-Nafāis, 1988)

Muhammad ibn 'Ali Muhammad al-Syaukānī, Fath al-Qadīr, (Beirut: Dār al-Fikr, tth.), Juz III

Muhammad Nawawī al-Jāwī, Marāh Labid, (Beirut: Dār al-Fikr), Jilid I.

Muslim ibn al-Hajjāj Ab- al-Husayn al-Qusyairī al-Naisābūrī, Shahīh Muslim, Juz I, (Beirut: Dār Ihyā' al-Turāts al-'Arabī, t.th).

Tim Penyusun, Kamus Besar Bahasa Indonesia (Jakart: Balai Pustaka, 1989)

Undang-undang No. 2 tentang "Sistem Pendidikan Nasional," tahun 1989

Warson Munawwir, al-Munawwir Kamus Arab - Indonesia (Yogyakarta: UPBIK Pondok Pesantren Al-Munawwir, 1984) 


\title{
SIGNIFIKANSI MAQAMAT DAN AMALAN PADA PENDIDIKAN TASAWUF DALAM PERUBAHAN TINGKAH LAKU MANUSIA
}

\author{
Mihmidaty \\ (Dosen DPK UIN Sunan Ampel di FAI Universitas Sunan Giri \\ Surabaya)
}

\begin{abstract}
Abstrak:
Masyarakat dewasa ini cenderung mengikuti gaya hidup materialistic hedonistic. Pada umumnya kontak antar manusia atas dasar prinsip-prinsip fungsional, pragmatis, materialis. Manusia yang seperti itu ternyata tidak bahagia dan diliputi kegelisahan, sehingga terjadi kekeringan spiritual. Oleh karena itu sebagian manusia kembali kepada nilai-nilai keagamaan, cenderung ke arah spiritualisme. Pendidikan tasawuf merupakan alternatif untuk mengatasi masalah ini. Pendidiknya adalah seorang guru yang ma'rifat (mengenal rahasia Ketuhanan) yang diberi kemampuan oleh Allah SWT untuk membimbing jiwa menuju pada kedekatan dengan Allah SWT dan mencapai kebahagiaan yang hakiki, melalui ajaran maqamat dan amalan-amalan tertentu secara disiplin, sehingga dapat menimbulkan perubahan tingkah laku.
\end{abstract}

Kata Kunci: Maqamat, Amalan, Pendidikan Tasawuf dan Tingkah Laku

\section{A. Pendahuluan}

Allah menciptakan jiwa manusia dilengkapi dengan sifat fujur (penentangan/durhaka/kefasikan) dan ketaqwaan, sebagaimana firman-Nya: 


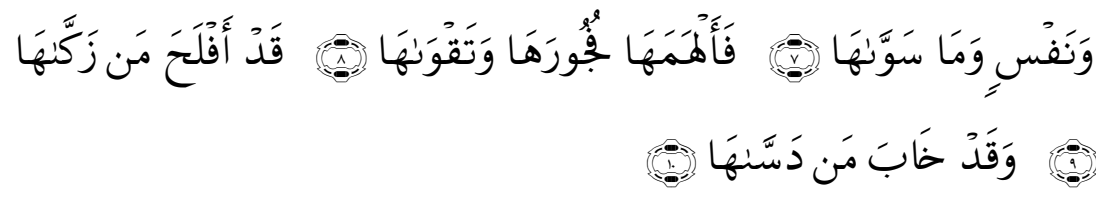

"Dan jiwa serta penyempurnaannya (penciptaannya), Maka Allah mengilhamkan kepada jiwa itu (jalan) kefasikan dan ketakwaannya. Sesungguhnya beruntunglah orang yang mensucikan jiwa itu, dan sesungguhnya merugilah orang yang mengotorinya."

Dalam ayat ini, Allah SWT menyebutkan kata fujur lebih dahulu daripada kata taqwa, hal ini memberikan sinyal kepada manusia bahwa jiwa manusia itu yang asal adalah durhaka/ fasik, oleh karena itu perlu dididik, diajar dan dilatih supaya bisa mencapai pada ketaqwaan. Pada ayat berikutnya Allah memberi pelajaran, sungguh berbahagialah orang yang mensucikan jiwa itu dan sungguh merugilah orang yang mengotorinya.

Bukan sesuatu yang mudah untuk mengubah dari jiwa yang durhaka menjadi jiwa yang taqwa, dari jiwa yang kotor menjadi jiwa yang suci. Salah satu solusinya adalah melalui pendidikan tasawuf dengan materi-materi pendidikan tasawuf yang sangat berharga. Materi pendidikan tasawuf tersebut adalah berupa maqamat atau tahapan-tahapan tertentu dan amalan-amalan yang harus dilaksanakan dalam kehidupan sehari-hari.

\section{B. Maqamat}

Maqamat adalah tingkatan-tingkatan atau tahapantahapan jalan pendakian yang harus dilalui oleh seorang murid

${ }^{1}$ Al-Qur'an, 91 (al-Shams): 7-10. 
untuk mengikuti pendidikan tasawuf yang harus diusahakan secara sungguh-sungguh dalam perjalanan hidupnya. Tingkatan-tingkatan dalam maqamat ini banyak macamnya, para sufi berbeda pendapat tentang jumlahnya, ada yang membedakan antara maqamat dengan ahwal (kondisi jiwa sufi sebagai anugrah dari Allah SWT tidak melalui usaha yang sungguh-sungguh), ada pula yang tidak membedakannya, misalnya, dalam kitab Risalah al-Qusyairiyyah terdapat empat puluh sembilan maqamat, tanpa membedakannya dengan ahwal ${ }^{2}$ tersebut.

Amalan atau perbuatan maqamat ini kalau disederhanakan antara lain berupa:

\section{Taubat}

Taubat adalah awal tempat pendakian dan maqam pertama bagi murid. Hakikat taubat menurut arti bahasa adalah "kembali", kata taba berarti kembali, maka tawbah maknanya juga kembali, artinya kembali dari sesuatu yang dicela dalam syari'at menuju sesuatu yang dipuji dalam syari'at. Allah SWT berfirman:

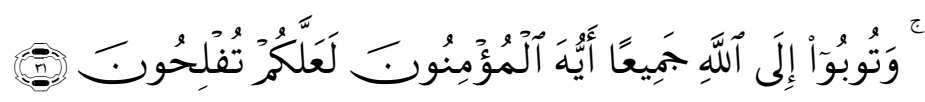

"Dan bertaubatlah kamu sekalian kepada Allah, Hai orangorang yang beriman supaya kamu beruntung."3

Rasulullah SAW. bersabda:

التائب من الذنب كمن لا ذ نب واذا احب الله عبدا لم يضره ذنب

\footnotetext{
${ }^{2}$ Abu al-Qasim 'Abd al- Karim al Qushairy, Risalah al-Qushairiyah (Kairo: Dar alKhair, tt), 115.

3 Al-Qur'an, 24 (al-Nur): 31.

Jurnal Pendidikan Agama Islam

Volume 02 Nomor 01 Mei 2014

Hal $54-87$
} 
"Seorang yang bertaubat dari dosa sama dengan orang yang tidak punya dosa, dan jika Allah mencintai seorang hamba, pasti dosa tidak akan membahayakannya."4

Sesuai dengan firman Allah SWT:

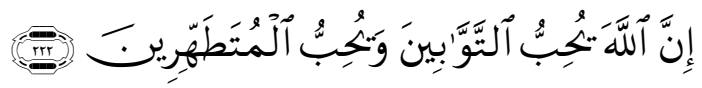

"Sesungguhnya Allah menyukai orang-orang yang bertaubat dan menyukai orang-orang yang mensucikan diri."5

Orang yang bertaubat harus memenuhi syarat: alnadm, al-iqla', al-istighfar, al-ta'abbud. ${ }^{6}$ Pertama, al-nadm berarti penyesalan dari perbuatan-perbuatan dosa, kedua, al-iqla' maksudnya menanggalkan perbuatan-perbuatan dosa seraya berjanji kepada Allah tidak akan mengulangi perbuatan dosanya, ketiga, al-istighfar adalah permohonan ampun yang sungguh-sungguh kepada Allah SWT atas segala dosanya dan yang keempat, al-ta'abbud yaitu rajin melakukan ibadah atau penghambaan diri kepada Allah SWT selama hidupnya.

Demikianlah syarat taubat yang dilakukan oleh seseorang pada umumnya, yaitu karena membersihkan diri dari kesalahan dan dosa. Namun bagi orang-orang tertentu yang terpilih (khas), taubat mereka bukan karena melakukan dosa atau kejahatan, tetapi taubat mereka adalah karena lupa atau lalai (ghaflah) dari mengingat kepada Allah SWT. ${ }^{7}$ Orang yang telah menempati maqam tinggi seperti ini, ia selalu mengingat dan dzikir kepada Allah SWT dalam

${ }^{4}$ Al-Jami' al-Shaghir Juz I, 3385

5 Al-Qur'an, 2 (al-Baqarah): 222.

6 'Abd al-Wahab al-Sha'rani, Minah al-Saniyyah (Surabaya: al-Hidayah, tt.), 2.

7 Ibn 'Athaillah, Miftah al-Falah wa Mishbah al-Arwah (Mesir: Maktabah 'Ali Shabih wa Awladih, tt.), 27. 
setiap keadaan. Apabila ia melupakan-Nya dalam waktu sebentar saja, ia merasa telah melakukan dosa dan memohon ampun kepada-Nya karena kelalaiannya dalam berdzikir kepada Allah SWT.

\section{Istiqamah}

Istiqamah berarti kebenaran atau ketulusan ${ }^{8}$ dalam melaksanakan pengabdian diri kepada Allah SWT, secara terus menerus tanpa menghitung-hitung berapa banyak ia telah melakukan kabaikan. Sebagaimana sabda Nabi SAW:

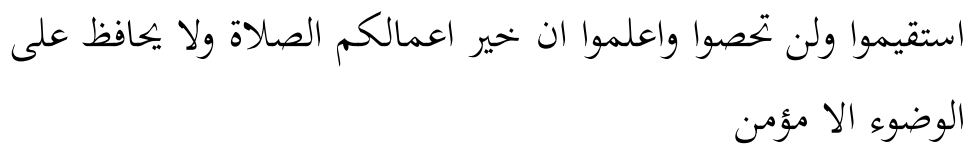

"Istiqamahlah kamu dan jangan sekali-kali menghitunghitung (amal)mu. Ketahuilah bahwa sebaik-baik (amalan) agamamu adalah shalat, dan tidak ada yang mampu menjaga wudlu selain orang mukmin." 9

Dengan demikian, istiqamah berarti teguh pendirian dalam bersikap. Sedangkan dalam beribadah adalah konsisten dan terus menerus dalam pengamalannya.

Istiqamah merupakan syarat utama bagi pemula dalam menjalani perjalanan pendidikan tasawuf. Statusnya masuk kalkulasi hukum-hukum dasar perjalanan awal shufi. Diantara tanda-tanda istiqamah bagi shufi pemula adalah ketiadaan perubahan pelaksanaan ibadahnya, meskipun hanya sekejap. ${ }^{10}$ Orang yang tidak bisa istiqamah dalam ibadahnya, maka usahanya menjadi sirna dan perjuangannya dihitung gagal. Hanya orang-orang yang

\footnotetext{
8 Muhammad Idris, Kamus Idri sal-Marbawi Jilid II, 164.

9 Imam Ibnu Majah,Sunan Ibnu Majah, Juz I ( Beirut: Dar al-Fakr, 2004), 103.

${ }_{10}$ Abu al-Qasim, Risalah, 294.
} 
berjiwa besar saja yang dapat menjalankan istiqamah ini. Allah SWT juga memerintahkan istiqamah dengan firmanNya:

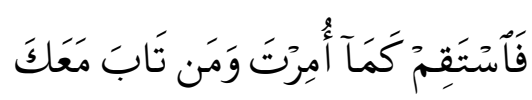

"Maka tetaplah kamu (istiqamah) pada jalan yang benar, sebagaimana diperintahkan kepadamu dan (juga) orang yang telah taubat beserta kamu."11

Allah SWT akan menganugerahkan kebaikan kepada orang yang dapat melaksanakan istiqamah ini, dengan firmanNya:

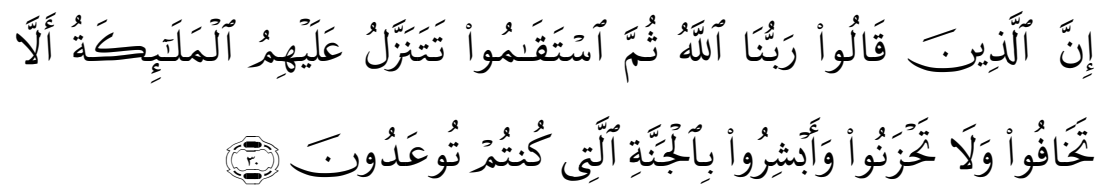

"Sesungguhnya orang-orang yang mengatakan: 'Tuhan Kami ialah Allah' kemudian mereka meneguhkan pendirian mereka, Maka Malaikat akan turun kepada mereka dengan mengatakan: Janganlah kamu takut dan janganlah merasa sedih; dan gembirakanlah mereka dengan jannah (surga) yang telah dijanjikan Allah kepadamu".12

Demikianlah penjelasan Allah SWT bahwa orang yang dapat melaksanakan istiqamah dalam pengabdian diri kepada-Nya, maka Allah SWT menjamin tidak akan ada ketakutan dan kesedihan dalam hidupnya dan Allah SWT menjanjikan kebahagiaan di surga kelak di akhirat.

${ }^{11}$ Al-Qur'an, 11 (Hud): 112.

12 Al-Qur'an, 41 (Fushshilat): 30. 
Dan firman-Nya:

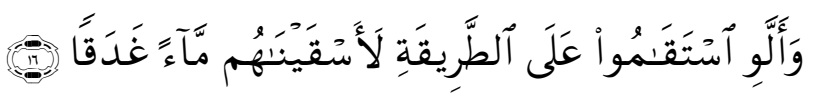

"Dan bahwasanya: Jikalau mereka tetap berjalan lurus (istiqamah) di atas jalan itu (agama Islam), benar-benar Kami akan memberi minum kepada mereka air yang segar (rezki yang banyak)."13

Dalam ayat tersebut, Allah SWT memotivasi pada manusia agar menerapkan istiqamah dalam hidupnya. Hal ini telah dilaksanakan dalam pendidikan tasawuf. Murid yang telah menerapkan istiqamah ini, memiliki empat tanda/ciri pada dirinya, yaitu: 1). Kalau diberi kebaikan oleh seseorang, tidak mendorongnya untuk berbuat baik pada orang yang memberi. 2). Kalau dijeleki oleh seseorang, tidak mendorongnya untuk berbuat jelek kepadanya. 3). Hawa nafsunya tidak memalingkan ketaatannya kepada Allah SWT. 4). Harta benda tidak menyurutkan hatinya dalam taat kepada Allah SWT. ${ }^{14}$

Hal tersebut terjadi karena dia berkeyakinan bahwa kebaikan hanya datang dari Allah SWT saja, demikian juga kejelekan, hawa nafsu dan harta benda yang diberikan oleh Allah SWT kepada manusia, untuk menguji, yang disikapinya dengan sabar dan syukur.

\section{Zuhud}

Ibnu 'Ujaibah mendefinisikan zuhud dengan perkataannya, "Zuhud adalah kosongnya hati dari ketergantungan kepada selain Allah SWT." Zuhud berarti

\footnotetext{
${ }^{13}$ Al-Qur'an, 72 (al-Jin):16.

14 Shaykh Mas'ud Thaha, Murshid Thariqah Shahaliyah dan Pengasuh Pondok Pesantren Nurul Huda Magelang, Ceramah, Magelang, 16 November 1999.
} 
mengosongkan hati dari cinta kepada dunia dan semua keindahannya, dan mengisinya dengan cinta kepada Allah SWT serta ma'rifat kepada-Nya. ${ }^{15}$ Kalau hati manusia terlepas dari ketergantungan pada dunia dan kesibukannya, maka akan menambah cintanya kepada Allah SWT, berserah diri dan menghadapkan perhatian kepada Allah SWT.

Al-Sarraj menegaskan bahwa zuhud adalah maqam yang mulia, dan ini merupakan langkah awal bagi seseorang yang menuju Allah SWT. ${ }^{16}$ Perumpamaan antara dunia dengan akhirat adalah seperti seorang nenek tua keriput yang penuh penyakit dan seorang gadis muda yang cantik. ${ }^{17}$ Jika seorang pemuda mau menikah tentu memilih seorang gadis muda yang cantik. Seorang mu'min tentu memilih kehidupan akhirat yang diibaratkan gadis cantik itu. Jadi zuhud adalah keinginan hati untuk tidak menginginkan segala kepentingan dunia.

Oleh karenanya, dalam al-Qur'an banyak ayat yang memandang rendah urusan dunia, menjelaskan kehinaannya dan kenikmatannya yang mudah hilang serta menekankan bahwa dunia tempat tipu daya, kebohongan dan fitnah bagi orang-orang yang lalai. Hal ini dimaksudkan agar manusia zuhud terhadap dunia dengan menghilangkan kecintaan dunia dalam hati mereka, sehingga dunia tidak menyibukkan mereka dari tujuan penciptaan manusia yang sebenarnya yaitu mengabdi dan menghamba kepada Allah SWT saja.

\footnotetext{
15 'Abdul Qadir 'Isa, Hakikat Tasawuf ( Jakarta: Qisthi Press, 2005), 248.

${ }^{16} \mathrm{Al}$-Sarraj, al-Luma' fi al-Tashawwuf (Kairo: Dar al-Kutub al-Hadithah,1960), 72.

17 'Ali Hasan al-'Aridh, Bahjat al-Nufus li Ibn 'Athaillah (Kairo: M.Taufiq Uwaudhat,1969), 162.
} 
Firman Allah SWT tersebut antara lain adalah:

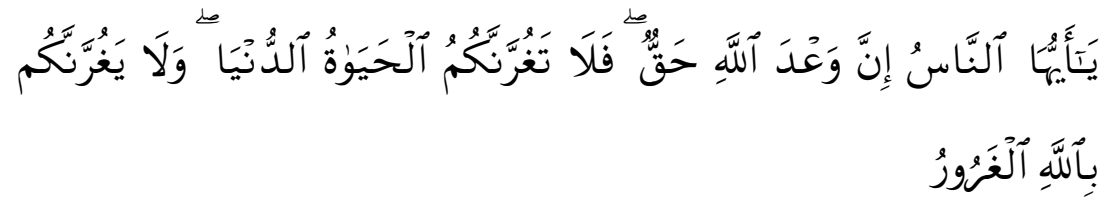

"Hai manusia, Sesungguhnya janji Allah adalah benar, maka sekali-kali janganlah kehidupan dunia memperdayakan kamu dan sekali-kali janganlah syaitan yang pandai menipu, memperdayakan kamu tentang Allah."18

Dan firman Allah SWT:

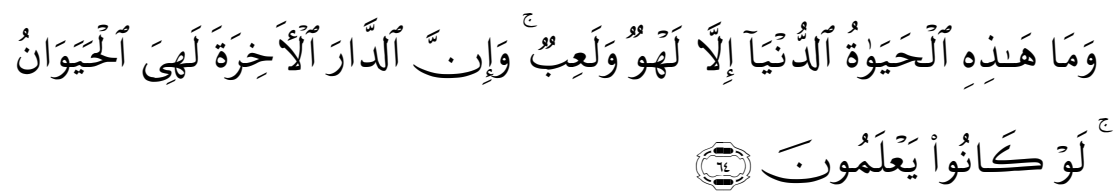

"Dan Tiadalah kehidupan dunia ini melainkan senda gurau dan main-main. dan Sesungguhnya akhirat Itulah yang sebenarnya kehidupan, kalau mereka mengetahui."19

Serta firman Allah SWT:

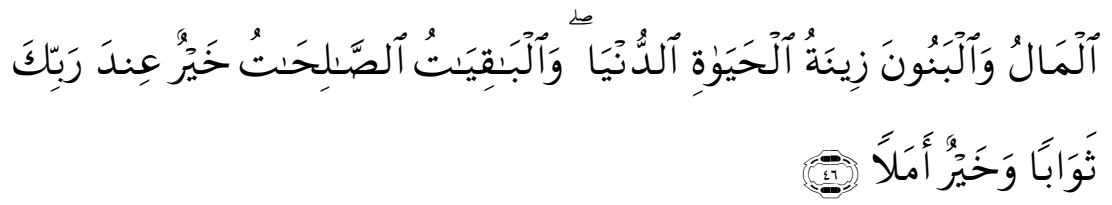

"Harta dan anak-anak adalah perhiasan kehidupan dunia tetapi amalan-amalan yang kekal lagi saleh adalah lebih baik pahalanya di sisi Tuhanmu serta lebih baik untuk menjadi harapan."20

\footnotetext{
${ }^{18}$ Al-Qur'an, 35 (al-Fathir): 5.

${ }^{19}$ Al-Qur'an, 29 (al-Ankabut): 64.

${ }^{20}$ Al-Qur'an, 18 (al-Kahfi): 46. 
Allah SWT juga berfirman:

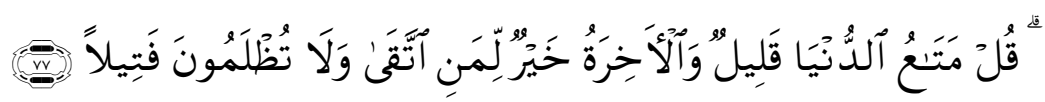

"Katakanlah: "Kesenangan di dunia ini hanya sebentar dan akhirat itu lebih baik untuk orang-orang yang bertakwa, dan kamu tidak akan dianiaya sedikitpun."21

Demikian Allah SWT memberi pelajaran kepada manusia agar hati-hati tentang urusan dunia dan mengutamakan semua urusan yang berhubungan dengan Allah SWT untuk persiapan mencapai kebahagiaan dalam kehidupan yang sebenarnya yaitu kehidupan di akhirat. Hal ini telah diejawantahkan oleh Rasulullah SAW. sebagai uswah hasanah (contoh teladan yang baik) bagi ummatnya. Sebagaimana yang diillustrasikan oleh 'Urwah dari 'Aisyah:

$$
\begin{aligned}
& \text { عن عروة عن عائسة رضي الله عنها انها كانت نقول: والله يا ابن اختى ان } \\
& \text { كنا لننظر المى الهلال ثم الهلال ثم الهلال ثلاثة اهلة في شهرين. وما اوقد في } \\
& \text { ابيات رسول الله صل الله عليه وسلم نار قال: قلت يا خالة ! فما كان } \\
& \text { يعيشكم؟ قالت: الاسودان: التمر و الماء. الا انه قد كان لرسول الله صل } \\
& \text { الله عليه وسلم جيران من الانصار . وكانت لهم منائح فكانوا يرسلون الى رسول } \\
& \text { الله صل الله عليه وسلم من الباها فيسقينا هـ }
\end{aligned}
$$

"Diriwayatkan dari 'urwah dari 'Aisyah r.a. dia berkata"Demi Allah, hai kemenakanku, kami pernah menghitung awal tanggal sampai awal tanggal berikutnya, sampai tanggal berikutnya lagi yaitu tiga kali awal tanggal selama dua bulan tidak ada sesuatu yang dimasak di dapur Rasulullah SAW. 'Urwah bertanya, 'Hai bibi, lalu kalian semua makan apa?'

${ }^{21}$ Al-Qur'an, 4 (al-Nisa'): 77. 
'Aisyah r.a. menjawab, 'Kurma dan air'. Hanya Rasulullah SAW. Bertetangga dengan orang-orang Anshar dan mereka mendapat banyak rizki, sehingga mereka sering mengirimkan sebagian air susu hewan mereka kepada Rasulullah SAW., lalu; kami menghidangkannya kepada beliau."22

Rasulullah SAW. juga memberikan pengertian yang benar tentang zuhud dengan sabdanya:

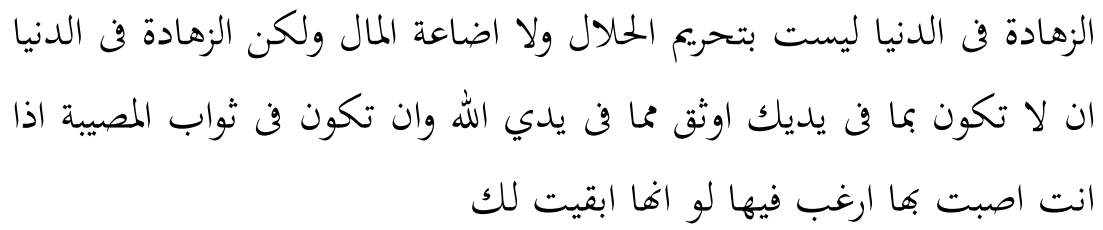
"Zuhud terhadap dunia bukanlah mengharamkan yang halal dan menyia-nyiakan harta, akan tetapi, zuhud terhadap dunia adalah engkau lebih percaya pada apa-apa yang ada di sisi Allah daripada apa-apa yang ada di tanganmu, dan pahala musibah yang menimpamu membuatmu lebih suka seandainya ia terus menimpamu."23

Dari hadith tersebut, dapat dimengerti bahwa zuhud adalah kondisi hati, bukan berarti melepaskan diri dari halhal duniawi, sehingga mengosongkan tangannya dari harta, meninggalkan usaha halal dan menjadi beban bagi orang lain. Tetapi hatinya tetap dihadapkan kepada Allah SWT dengan memanfaatkan dunia untuk mencapai kebahagiaan akhirat, karena akhirat tidak akan didapat kecuali dengannya. Ayat-ayat al-Qur'an dan hadith-hadith tersebut bukanlah celaan pada dunia itu sendiri, tetapi maksudnya adalah peringatan agar hati manusia tidak sibuk dengannya,

22 Imam Bukhari, Shahih Bukhari, Juz II (Beirut: Dar al-Kutub al-'Ilmiyah, 2005), 165. Lihat juga Imam Muslim, Shahih Muslim, Juz II, 589.

${ }^{23}$ Imam Tirmidhi, Sunan al-Tirmidhi (Beirut: Dar Ibnu Hazm, 2002), 673-674, 
dengan menjadikannya sebagai tujuan dan berusaha sekuat mungkin untuk memperolehnya, serta melupakan tujuan hidup yang utama, yaitu meraih ridha Allah SWT.

Cara untuk mencapai zuhud antara lain yang paling penting adalah bergaul atau berguru pada murshid yang dapat menunjukkannya pada jalan yang benar, membawanya dari tingkatan yang satu ke tingkatan yang lain dengan cara yang bijaksana dan menjauhkannya dari hal-hal yang dapat menjerumuskan. ${ }^{24}$

Dalam hal ini, seorang murshid kadang menugaskan bentuk mujahadah tertentu kepada murid-muridnya agar mereka dapat mengosongkan hati mereka dari ketergantungan terhadap dunia. Dia memerintahkan pada mereka agar memakan makanan yang sedikit dan memakai pakaian yang sederhana, untuk menghilangkan kecintaan terhadap dunia dari hati mereka; atau dia mengajak mereka berderma dengan jumlah yang besar untuk kepentingan agama Allah SWT agar dapat melepaskan sifat-sifat kikir dan kecintaan terhadap harta benda dari hati mereka. Hal ini hanyalah sarana yang di-shari'at-kan untuk mencapai zuhud hati yang hakiki, yang merupakan sebab untuk sampai kepada Allah SWT, karena hati tidak akan sampai kepadaNya apabila masih bergantung pada sesuatu selain Allah SWT.

\section{Raja'}

Raja' adalah kepercayaan dan pengharapan atas ridha dan karunia Allah SWT yang dibuktikan dengan amal. ${ }^{25}$ Ada yang berpendapat bahwa raja' merupakan sikap percaya terhadap kedermawanan Allah SWT. Pendapat lain

24 'Abdul Qadir, Hakikat, 256.

25 Abu 'Abbas Ahmad Zaruq al-Fasi, Qawa'id al-Tashawwuf, 74. 
mengatakan raja' adalah senangnya hati terhadap tempat kembali yang baik (akhirat). Ada pula yang berpendapat raja' adalah dekatnya hati terhadap kelemah-lembutan Tuhan. ${ }^{26}$ Hal ini diperintahkan oleh Allah SWT pada manusia agar mengharapkan karunia-Nya dan melarang berputus asa dari rahmat-Nya. Sebagaimana firman Allah SWT:

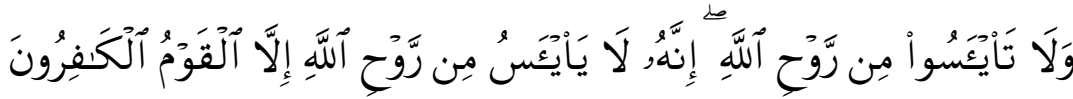

"Dan jangan kamu berputus asa dari rahmat Allah. Sesungguhnya tiada berputus asa dari rahmat Allah, melainkan kaum yang kafir." 27

Allah SWT menyifati orang yang selalu mengharap rahmat-Nya dalam firman-Nya:
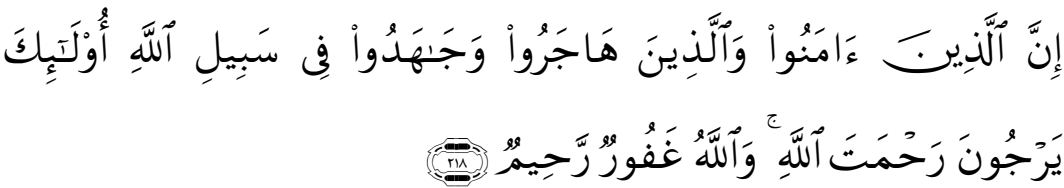

"Sesungguhnya orang-orang yang beriman, orang-orang yang berhijrah dan berjihad di jalan Allah, mereka itu mengharapkan rahmat Allah, dan Allah Maha Pengampun lagi Maha Penyayang."28

Dan firman Allah SWT:

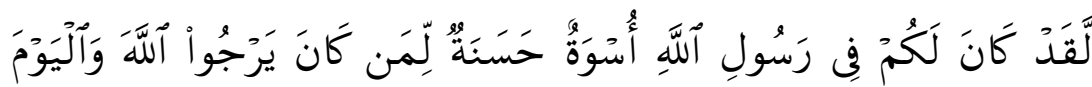

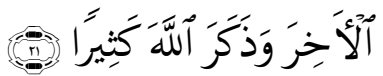

"Sesungguhnya telah ada pada (diri) Rasulullah itu suri teladan yang baik bagimu (yaitu) bagi orang yang

\footnotetext{
${ }^{26}$ Abu al-Qasim, Risalah al-Qushairiyah, 179.

27 Al-Qur'an, 12 (Yusuf), 87.

28 Al-Qur'an, 2 (al-Baqarah): 218. 
mengharap (rahmat) Allah dan (kedatangan) hari kiamat dan Dia banyak menyebut Allah."29

Orang yang mengharap dan mencari rahmat Allah SWT, akan berusaha dengan sungguh-sungguh dan berijtihad dengan penuh ketulusan dan keikhlasan sampai dia memperoleh apa yang dicita-citakan. Firman Allah:

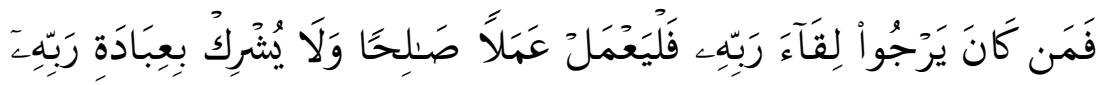
أَعَدَرام

"Barangsiapa mengharap perjumpaan dengan Tuhannya, Maka hendaklah ia mengerjakan amal yang saleh dan janganlah ia mempersekutukan seorangpun dalam beribadat kepada Tuhannya."30

Oleh karena itu, sebenarnya raja' (harapan) adalah ketergantungan hati pada sesuatu yang dicintai atau yang diinginkan yang akan terjadi pada masa yang akan datang. Sebagaimana khawf (rasa takut) yang juga berhubungan dengan sesuatu yang akan terjadi di masa yang akan datang.

Seseorang yang sedang menghadap kepada Allah dan berjalan untuk mencapai kedekatan di sisi-Nya, maka sebaiknya dia menggabungkan antara khawf dan raja. Terbang dengan kedua sayap itu (khawf dan rajā) di udara yang jernih, sehingga dapat mencapai kedekatan di hadirat Allah. Dengan demikian dapat mewujudkan sifat orangorang yang disebutkan oleh Allah SWT dalam firman-Nya:

${ }^{29}$ Al-Qur'an, 33 (al-Ahzab): 21.

30 Al-Qur'an, 18 ( al-Kahfi), 110. 


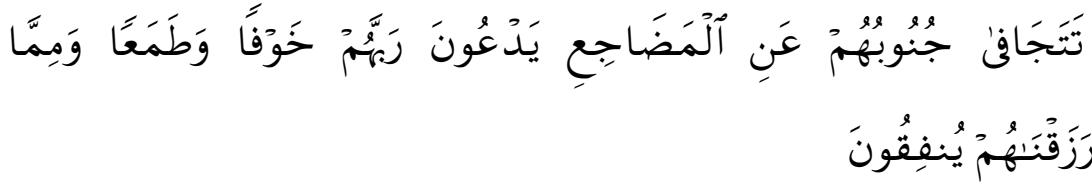

"Lambung mereka jauh dari tempat tidurnya"1 dan mereka selalu berdoa kepada Rabbnya dengan penuh rasa takut dan harap, serta mereka menafkahkan apa apa rezki yang Kami berikan." 32

Dalam arti takut neraka-Nya dan mengharap surgeNya, takut jauh dari-Nya dan mengharap untuk berada di dekat-Nya, takut dibenci-Nya dan mengaharap ridha-Nya, takut putus hubungan dengan-Nya dan mengharap dapat terus berinteraksi dengan-Nya.

\section{Qana'ah}

Menurut Abu 'Abdillah bin Khafif, qana'ah adalah meninggalkan angan-angan terhadap sesuatu yang tidak ada dan menganggap cukup dengan sesuatu yang ada.33 Sedangkan menurut Muhammad bin 'Ali al-Turmuzi, qana'ah adalah jiwa yang rela terhadap rizki yang telah ditentukan. Pendapat yang lain menyatakan qana'ah adalah menganggap cukup dengan sesuatu yang ada dan tidak berkeinginan terhadap sesuatu yang tidak ada hasilnya serta rela terhadap keputusan Allah SWT. ${ }^{34}$

Orang yang dapat memasukkan qana'ah dalam jiwanya, akan diberi oleh Allah SWT kehidupan yang baik di dunia, kemulyaan dan kekayaan. Allah SWT berfirman:

31 Maksudnya mereka tidak tidur di waktu biasanya orang tidur untuk mengerjakan shalat malam.

32 Al-Qur'an, 32 (al-Sajdah), 16.

${ }^{33}$ Al-Qusyairy, Risalah, 221.

${ }^{34}$ Al-Qusyairy, 222. 


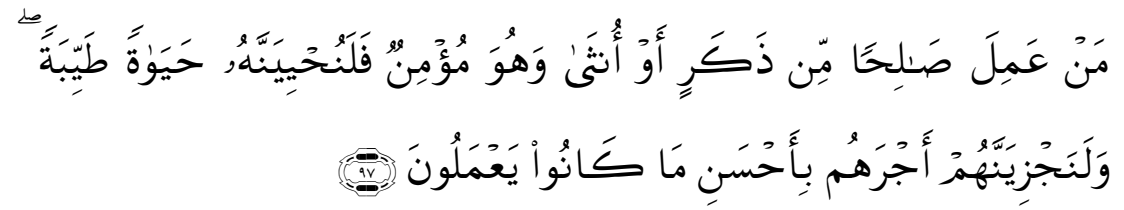

"Barangsiapa yang mengerjakan amal saleh, baik laki-laki maupun perempuan dalam Keadaan beriman, Maka Sesungguhnya akan Kami berikan kepadanya kehidupan yang baik dan Sesungguhnya akan Kami beri Balasan kepada mereka dengan pahala yang lebih baik dari apa yang telah mereka kerjakan."35

Dan firman Allah SWT:

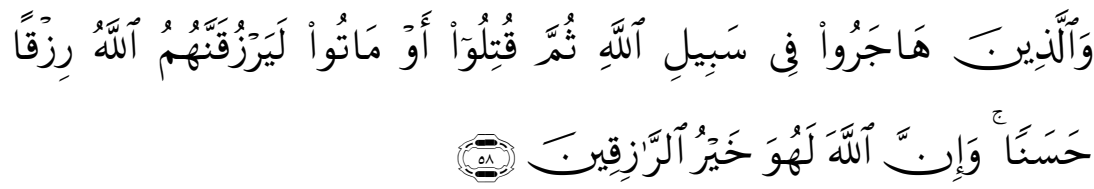

"Dan orang-orang yang berhijrah di jalan Allah, kemudian mereka di bunuh atau mati, benar-benar Allah akan memberikan kepada mereka rezki yang baik (surga). dan Sesungguhnya Allah adalah Sebaik-baik pemberi rezki."36

Para ahli tafsir mengatakan, "Kehidupan yang baik di dunia adalah qana'ah (menerima atau merasa puas)". Dan yang dimaksud firman Allah SWT Dia akan memberikan rizki kepada mereka degan rizki yang baik adalah "qana'ah".

\section{Amalan-amalan dalam Pendidikan Tasawuf}

\section{Istighfar}

Istighfar adalah memohon ampun kepada Allah SWT dari segala dosa yang telah dilakukan oleh seseorang. Esensi

${ }^{35}$ Al-Qur'an, 16 (al-Nahl): 97.

36 Al-Qur'an, 22 (al-Hajj): 58. 
istighfar adalah taubat dan kembali kepada Allah SWT dari hal-hal yang tercela menuju hal-hal yang terpuji. Ibn 'Athaillah menyatakan bahwa seorang murid yang melangkah menuju Allah SWT, apabila sebelumnya merasa banyak melakukan dosa dan kejahatan, maka mulailah dengan banyak membaca istighfar atau meminta ampun kepada Allah SWT sampai kelihatan buahnya. ${ }^{37}$

Orang yang mengucapkan istighfar pada hakikatnya adalah mengakui dan menyesali kesalahan-kesalahan yang telah diperbuat, ia berjanji kepada Allah SWT untuk tidak mengulangi perbuatannya yang salah, baik yang tersembunyi maupun yang kelihatan. Jika janji taubat itu diucapkan karena manusia lain, maka janji itu adalah palsu karena ia tak akan berbuat kesalahan lagi jika dilihat oleh orang lain, tetapi ia akan mengulangi perbuatannya jika tidak ada seorang pun yang melihatnya. Inilah taubat orangorang awam yang disinyalir oleh Zunnun al-Mishri, yaitu taubat dari dosa-dosanya yang telah diperbuat. ${ }^{38}$

Allah SWT berfirman:

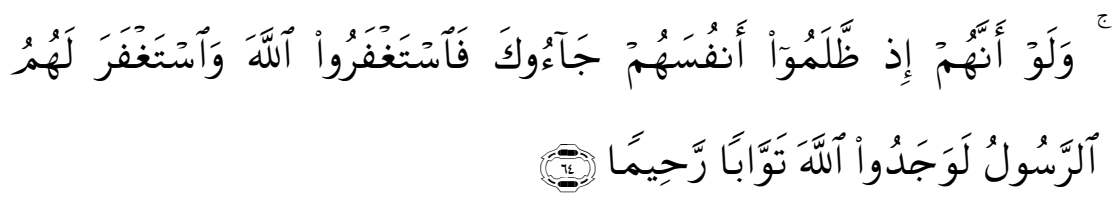

"Sesungguhnya Jikalau mereka ketika menganiaya dirinya datang kepadamu, lalu memohon ampun kepada Allah, dan Rasulpun memohonkan ampun untuk mereka, tentulah mereka mendapati Allah Maha Penerima taubat lagi Maha Penyayang."39

\footnotetext{
37 'Abdul Kadir, Hakikat, 248.

38 'Abdul Kadir, Hakikat, 248.

${ }^{39}$ Al-Qur'an, 4 (al-Nisa'), 64. 
Rasulullah SAW bersabda:

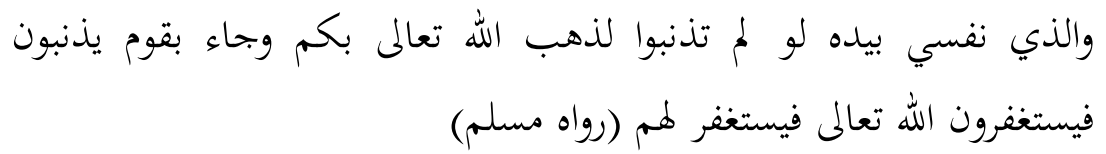

"Demi Dhat yang menguasai diriku, apabila kamu sekalian melakukan dosa maka Allah akan meninggalkanmu, dan ada suatu kaum yang melakukan dosa dan mereka mohon ampun kepada Allah, maka Allah pun mengampuni mereka."40

Dari ayat dan hadith tersebut di atas, dapat difahami bahwa barang siapa yang melakukan kejahatan dan dosa sedangkan mereka sanggup dengan rendah hati memohon ampun kepada Allah SWT, maka Allah SWT akan mengampuninya. Apabila seseorang telah diampuni-Nya, maka ia kembali bersih dan tiada cela dalam dirinya, kebaikan bukanlah orang yang tidak pernah berbuat dosa, tetapi orang yang berbuat dosa dan menyadari kesalahannya serta memohon ampunan-Nya.

Adapun istighfar yang diajarkan dalam pendidikan tasawuf pada umunya adalah dengan membaca astghfirulla>hal ' $a z\} i<m$ dibaca seratus kali setiap setelah sholat fardlu. Hal juga perlu tetap dilakukan oleh seorang hamba yang telah diampuni dosanya dan dirinya telah kembali bersih dengan mengganti kotoran jiwa dan hati dengan tetap istiqa>mah membaca istighfar dan mengisi jiwa dan hatinya dengan berbagai kebaikan dan amal shaleh.

\section{Dzikir}

Termasuk amalan yang utama dalam pendidikan tasawuf adalah dzikir, yaitu mengingat dan selalu menyebut

40 Sayyid Ahmad Hashimi, Mukhtar al-Hadith al-Nabawiyyah (Kairo: Shirkah Nur Asia, tt), 184. 
nama Allah SWT. Dzikir adalah ajaran pertama yang diwahyukan Allah SWT kepada Nabi Muhammad SAW melalui Malaikat Jibril ketika berkhalwat di gua hira', sebelum Allah SWT menurunkan shari'at; shalat, zakat, puasa dan haji, dengan firman-Nya:

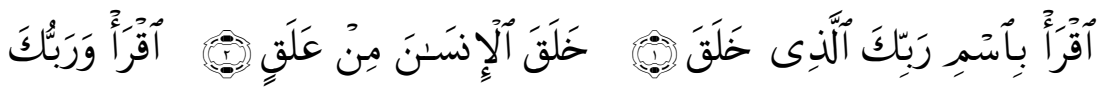

"1. Bacalah dengan (menyebut) nama Tuhanmu yang Menciptakan, 2. Dia telah menciptakan manusia dari segumpal darah. 3. Bacalah, dan Tuhanmulah yang Maha pemurah." 41

Kata "bacalah" pada ayat ini difahami sebagai dhikir, karena pada ayat tersebut dilanjutkan dengan menyebut nama Tuhanmu yang Maha menciptakan, yang telah menciptakan manusia dari segumpal darah dan Dia Maha pemurah, dan karena waktu diturunkan ayat ini belum ada al-Qur'an (belum ada yang dibaca). Allah SWT juga berfirman:

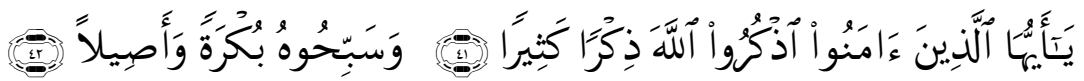

"Hai orang-orang yang beriman, berdhikirlah (dengan menyebut nama) Allah, dhikir yang sebanyak-banyaknya. Dan bertasbihlah kepada-Nya diwaktu pagi dan petang. 42

Dan firman Allah SWT:

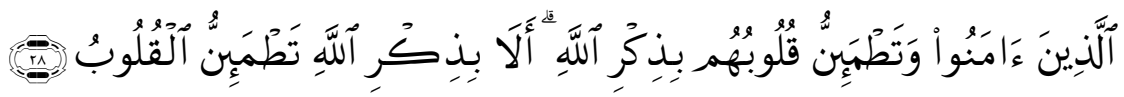

${ }^{41}$ Al-Qur'an, 96 (al-'Alaq): 1-3.

${ }^{42} \mathrm{Al}-Q u r^{\prime} a n, 33$ (al-Ahzab): 41-42. 
"(yaitu) orang-orang yang beriman dan hati mereka manjadi tenteram dengan mengingat Allah. Ingatlah, hanya dengan mengingati Allah-lah hati menjadi tenteram."43

Di dalam ayat tersebut Allah SWT memerintahkan kepada orang-orang yang beriman agar berdzikir atau selalu ingat kepada Allah SWT dengan membaca dzikir yang banyak. Dalam menyebut ayat tentang dzikir, Allah SWT sering kali memerintahkan dhikir yang banyak, mengapa demikian? Tentu Dia Yang Maha Tahu. Hanya saja kalau diperhatikan secara seksama, untuk dapat menghayati, memasukkan pemahaman tentang hakikat apa yang dibaca kedalam relung hati, maka membutuhkan proses pengulangulangan secara terus menerus. Berarti dengan kuantitas dzikir akan menimbulkan kualitas dhikir itu sendiri.

Dalam ayat berikutnya Allah SWT memberi pelajaran bahwa sesungguhnya hanya dengan menyebut nama-Nya atau berdhikir kepada-Nya, hati orang yang beriman dapat merasa tentram. Hal itu karena orang yang beriman adalah orang-orang yang mencintai Allah SWT, dan orang yang mencintai-Nya akan selalu menyebut nama-Nya, maka ia merasa tentram. Hal demikian adalah rasional karena secara psikologis kerinduan orang yang mencintai akan terpenuhi dengan selalu menyebut nama yang dicintainya dengan berharap bertemu dengan-Nya. Allah SWT akan hadir pada diri orang yang selalu ingat dan menyebut nama-Nya, bahkan lebih dekat dari pada urat nadinya. Rasulullah SAW bersabda:

${ }^{43}$ Al-Qur'an, 13 (al-Ra'd): 28. 


$$
\begin{aligned}
& \text { عن ابى هريرة رضى الله عنه ان رسول الله م قال: يقول الله تعالى انا عند } \\
& \text { ظنِ عبدى بى و انا معه اذا ذكرنى فاءن ذكرنى في نفسه ذكرته في نفسى وان } \\
& \text { ذكرنف في ملاء ذكرته في ملاء خيرمنهم وان تقرب الى شبرا تقربت اليه ذراعا } \\
& \text { وان تقرب الى ذراعا تقربت اليه باعا وان ان اتانى يمشى اتيته هرولة (رواه }
\end{aligned}
$$

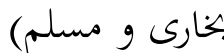

"Dari Abu Hurairah r.a. sesungguhnya Rasulullah bersabda bahwa Allah berfirman: Aku berada dalam prasangka hambaKu padaKu dan Aku menyertainya jika ia mengimgatKu, jika mengingatKu dalam dirinya maka Aku akan mengingatnya dalam diriKu dan jika mengingatKu dalam suatu kelompok (jama'ah) maka Aku akan mengingatnya dalam suatu kelompok (jama'ah) yang lebih baik dari itu, jika ia mendekatiKu sejengkal jari, maka Aku mendekatinya sepanjang siku-siku dan jika dia mendekatiKu sepanjang siku-siku, maka aku mendekatinya sepanjang hasta, dan jika dia mendatangiku dengan berjalan maka Aku mendatanginya dengan berlari." 44

Hadith tersebut menegaskan bahwa Allah SWT akan menyertai atau bersama orang yang senantiasa mengingat Allah SWT dalam dirinya baik secara individu maupun secara kolektif. Berarti Allah SWT sangat dekat dengan orang-orang yang selalu berdhikir kepada-Nya bahkan Allah SWT akan mengingat dan mendekat secara lebih baik dan lebih cepat daripada apa yang telah dilakukan oleh dhakir (orang yang mengingat Allah SWT). Jika seseorang mendekati-Nya dengan berjalan, maka Allah SWT akan

\footnotetext{
44 Imam Bukhari, Shahih Bukhari, Juz IV ( Beirut: Dar al-Kutub al 'Ilmiyah, 2005), 541. Lihat juga Imam Muslim, Shahih Muslim, Juz II (Mesir: Isa al-Babi alHalibi, tt.), 466.
} 
mendekati hamba-Nya dengan berlari agar segera saling bertemu (liqa') dan saling menyatu (ittihad).

Rasulullah Muhammad SAW bersabda:

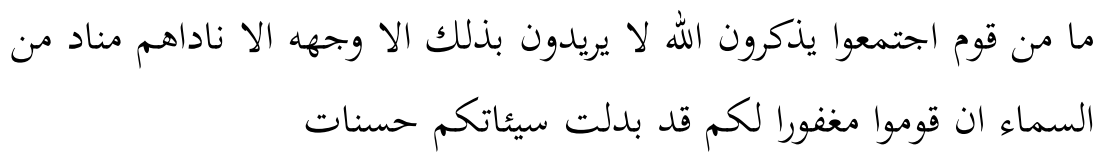

"Tidak ada segolongan manusiapun yang berkumpul dan melakukan dhikir kepada Allah dengan tidak ada niat lain selain untuk Allah semata-mata, kecuali nanti akan datang seruan dari langit:"Bangkitlah kamu semua, sudah diampuni dosa kalian dan sudah ditukar kejelekan kalian yang telah lalu dengan kebaikan." 45

Dzikir yang diamalkan oleh para murid dalam pendidikan tasawuf pada umumnya adalah kalimah thayyibah atau bacaan tahlil yang juga disebut dengan dhikir nafi (meniadakan) ithbat (menetapkan) yang berbunyi lailaha illalah (tidak ada Tuhan selain Allah SWT) dengan cara dibunyikan secara perlahan dan dibaca panjang dengan mengingat maknanya yaitu tiada dzat yang dituju kecuali Allah SWT (la maqshuda illa Allah), bacaan kedua dengan mengingat maknanya yaitu tiada yang disembah selain Allah SWT (la ma'buda illa Allah) dan bacaan ketiga dengan mengingat maknanya tiada yang ada selain Allah SWT (la maujuda illa Allah), diakhiri dengan bacaan sayyiduna Muhammad Rasulullah SAW. Kemudian diteruskan dhikir nafi ithbat: la ilaha illa Allah sebanyak seratus kali setiap setelah shalat fardlu. Dan dianjurkan dalam hati senantiasa dhikir ism al-dzat (menyebut nama Allah, Allah, Allah).

45 Imam Turmudzi, Sunan Turmudzi (Beirut: Dar al-Fikr,1980), 127-128. 
Mengucapkan amalan dzikir nafi ithbat ini biasanya dilakukan dengan merasakan bahwa dzikir itu "ditarik" melalui suatu alur di badannya, dari pusar ke otak, kemudian ke dada kanan dan dari sini dengan keras "dipukulkan" ke jantung (dada kiri). Demikian juga hati dibersihkan dari segala kotoran, sehingga di dalamnya tidak tersisa selain nama Allah SWT. Kepala juga ikut bergerak perlahan sesuai dengan alur dhikir, dari bawah ke atas (la), ke dada kanan (ilaha) dan akhirnya "dipukulkan" dengan keras ke jantung atau dada kiri (illa Allah) ${ }^{46}$

Amalan dhikir nafi ithbat (la ilaha illallah) ini dilakukan oleh murid terutama setelah shalat fardhu, sedangkan dhikir ism dzat (Allah) dilaksanakan setiap saat. Dalam hal ini Ibn 'Athaillah menyatakan, bahwa: Jangan engkau tinggalkan dhikir dikarenakan engkau tidak merasakan kehadiran Allah SWT dalam dhikir tersebut. Sebab kelalaianmu terhadapNya dengan tidak berdhikir kepada-Nya itu lebih berbahaya daripada kelalaianmu kepada-Nya dengan adanya dhikir kepada-Nya. ${ }^{47}$ Dhikir adalah sebaik-baik jalan menuju Allah SWT, jadi tidak boleh ditinggalkan walaupun sedang tidak konsentrasi penuh. Sebaiknya memang dengan menghadirkan Allah SWT dalam hati, sehingga mampu mencapai dhikir yang dapat melupakan segalanya selain Allah SWT.

Dalam hal ini Ibn 'Athaillah menganjurkan kepada seseorang yang ingin mencapai ma'rifat agar menempuh tujuh langkah: senantiasa bersungguh-sungguh (al-juhd), merendahkan diri kepada Allah SWT (al-tadharru),

\footnotetext{
46 Martin Van Bruinessen, Kitab Kuning, Pesantren dan Tarekat (Bandung: Mizan, 1995), 216.

47 Ibn 'Athaillah, Al-Hikam, terj. Salim Bahraish dengan judul terjemah al-Hikam, Pendekatan Abdi pada Khaliqnya (Surabaya: Balai Buku, 1984), 55.
} 
membakar hawa nafsu (ihtiraq al-nafs), kembali dan taubat kepada Allah SWT (al-inabah), senantiasa sabar (al-shabr), selalu bersyukur kepada Allah SWT (al-Syukr) dan senantiasa rela atas taqdir dan ketentuan Allah SWT (alridha). ${ }^{48}$

Memang untuk mendaki derajat yang tinggi harus dengan upaya yang sungguh-sunggh dan harus melatih diri untuk dapat mengalahkan segala rintangan yang menghalangi pendakian tersebut. Pada saatnya nanti Allah SWT akan menolong dengan memberikan petunjuk-Nya. Sebagaimana Firman-Nya:

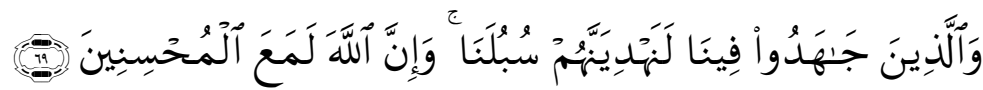

"Dan orang-orang yang berjihad untuk (mencari keridhaan) Kami, benar- benar akan Kami tunjukkan kepada mereka jalan-jalan kami. dan Sesungguhnya Allah benar-benar beserta orang-orang yang berbuat baik." 49

\section{Shalawat kepada Nabi Muhammad SAW}

Membaca shalawat kepada Nabi Muhammad SAW dengan maksud untuk memohonkan rahmat dan karunia bagi Nabi SAW agar yang membaca juga mendapat balasan limpahan rahmat dari Allah SWT. Ibn 'Athaillah menyarankan kepada para murid untuk selalu membaca shalawat Nabi siang malam terutama setelah shalat fardhu. Bacaan shalawat Nabi SAW dengan menggunakan sayyidina, karena di dalamnya terdapat rahasia yang luhur sebagai

48 Ibn 'Athaillah, Al-Hikam, 55.

${ }^{49}$ Al-Qur'an, 29 (al-Ankabut): 69 
ungkapan penghormatan khusus dan derajat cinta yang tinggi kepada Nabi Muhammad SAW. ${ }^{50}$

Membaca shalawat Nabi SAW merupakan ungkapan cinta (mahabbah) dari seorang pecinta kepada diri Nabi Muhammad SAW. Barang siapa mencintai seseorang maka ia akan selalu mengingatnya dan mendo'akannya agar selalu dalam rahmat-Nya. Dan tentu orang yang dicintai akan membalas segala kebaikan dan do'anya dengan penuh kasih sayang dan cinta. Demikian pula apabila seorang murid telah terjalin cinta karena Allah SWT (mahabbah fi Allah) dengan Nabi Muhammad SAW, maka tentu Allah SWT akan memberikan rahmat dan karunia kepada orang tersebut. Barang siapa mencintai Nabi Muahammad SAW berarti dia mencintai Allah SWT dan barang siapa yang dicintai oleh Allah SWT berarti dia dekat dengan-Nya (al-qurb). Allah SWT juga memerintahkan kepada manusia agar membaca shalawat kepada Nabi Muhammad SAW, dengan firman-Nya:

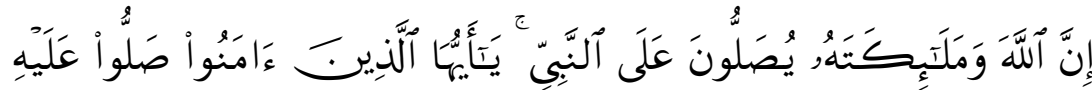

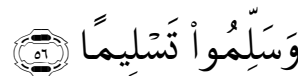

"Sesungguhnya Allah dan malaikat-malaikat-Nya bershalawat untuk Nabi. Hai orang-orang yang beriman, bershalawatlah kamu untuk Nabi dan ucapkanlah salam penghormatan kepadanya." ${ }^{\prime 51}$

Dalam tafsir al-Qur'an bershalawat artinya: kalau dari Allah berarti memberi rahmat; dari Malaikat berarti memintakan ampunan dan kalau dari orang-orang mukmin

50 Ibn 'Athaillah, Miftah al-Faidh wa Misbah al-Arwah (Mesir: Maktabah Muhammad Ali al-Shabi wa Awladih, tt.), 38.

51 Al-Qur'an, 33 (al-Ahzab): 56.

Jurnal Pendidikan Agama Islam 
berarti berdoa supaya diberi rahmat seperti dengan perkataan: Allahumma shalli 'ala Muhammad, artinya: Wahai Allah limpahkanlah rahmat yang sempurna kepada Nabi Muhammad SAW. Bacaan salam dengan mengucapkan perkataan seperti: Assalamu'alaika ayyuhan Nabiy artinya: semoga keselamatan tercurah kepadamu wahai Nabi. ${ }^{52}$

\section{Hizib}

Hizib menurut bahasa berarti tentara atau pasukan. Sedangkan istilah hizib digunakan sebagai sebutan suatu do'a yang cukup panjang dengan lirik dan bahasa yang indah yang disusun oleh ulama' besar. ${ }^{53}$ Hizib adalah kumpulan do'a khusus yang sudah populer di kalangan masyarakat Islam khususnya di pesantren dan thariqah. Hizib ini biasanya merupakan do‘a andalan seorang shaykh yang diberikan kepada muridnya secara ijazah yang jelas. Do‘a ini diyakini oleh kebanyakan masyarakat Islam atau kaum santri sebagai amalan yang memiliki daya spiritual yang besar. ${ }^{54}$

Daya spiritual hizib itu bukan dari jin tetapi dari Allah SWT. Apabila terjadi kasus seseorang yang mengamalkan hizib ini dan ternyata jin turut campur, maka yang perlu diluruskan adalah niat seseorang mengamalkan hizib tersebut. Amal sebaik apapun jika niat di dalam hatinya jahat, maka niat jahatnya itulah yang akan menjadi kenyataan dan hasilnya akan menuai sesuai dengan niatnya yang tidak ikhlas karena Allah SWT. Oleh karena itu seseorang yang akan mengamalkan hizib yang paling

53 Lihat Abi 'Abdillah, Dalail.

54 Masyhuri, Fenomena Alam jin, Pengalaman Spiritual dengan Jin (Solo: CV. Aneka, 1996), 7. 
penting adalah menata dan meluruskan niat dalam hati semata-mata hanya karena Allah SWT.

Shaykh Abu Hasan 'Ali al-Shadhili telah berwasiat kepada para pengikutnya dalam hal hizib ini sebagai berikut: "semua murid yang mengikuti thariqah Shadhiliyah supaya mengamalkan hizib al-bahr karena di dalamnya terdapat nama-nama Allah yang mulia, yang besar berkahnya"55 Dengan membaca asma' al-husna berarti seseorang berdhikir dan mengingat Allah SWT dengan 99 nama yang setiap nama memiliki pengaruh spiritual yang besar. Dan pengaruh spiritual itu akan didapat oleh siapapun yang mengamalkan, dengan syarat menerima ijazah dari guru yang berwenang.

Adapun hizib-hizib tersebut, antara lain adalah hizb alNasr, hizb al-kafi atau hizb al-autad, hizb al-bahr, hizb albarr, hizb al-mubarak, hizb al-asfa', hizb al-birhatiyah, hizb al-fath, hizb al-ayat, hizb al-Shaykh Abi al-Hasan, hizb alsaghir, hizb al-kabir .56 Hizib-hizib tersebut tidak boleh diamalkan oleh setiap orang, kecuali sudah mendapat izin atau ijazah dari murshid atau seorang murid yang ditunjuk oleh murshid untuk mengijazahkannya.

\section{5. 'Ataqah atau Fida'}

Ataqah menurut bahasa adalah pemerdekaan dan fida' adalah penebusan. Yang dimaksud 'ataqah adalah memerdekakan diri dari siksa api neraka dan fida' adalah menebus dosa, membersihkan jiwa dari kotoran-kotoran dan penyakit-penyakit jiwa dan untuk menebus dosa agar

\footnotetext{
55 'Abd al-Khaliq al-Hilali, Durrah al-Salikin fi Dhikr al-Silsilah al-Thariqah alSyadhiliyah al-Mu'tabarah (tp.: tt., 1980), 2.

56‘Abd al-Halim Mahmud, al-Madrasah al-Syadhaliyyah (Mesir: Dar al-Kutub alHadithah, 1968), 175-201.
} 
dapat masuk surga ${ }^{57}$. Atau penebus pengaruh jiwa yang tidak baik (untuk mematikan nafsu). ${ }^{58}$

Bentuk dan cara 'ataqah ini adalah berupa seperangkat amalan tertentu yang dilaksanakan dengan sungguh-sungguh (mujahadah) yaitu membaca surat ikhlas seratus ribu kali atau membaca kalimat tahlil la ilaha illa Allah sebanyak tujuh puluh ribu kali, dalam rangka penebusan dosa dan penebusan nafsu amarah dan nafsunafsu yang lain. Dalam pelaksanaan 'ataqah atau fida' ini bisa dicicil semampunya. ${ }^{59}$ Setiap kali selesai membaca diakhiri dengan do'a fida' dan dicatat jumlahnya agar diketahui batas akhir membacanya. Kalau sudah selesai membaca 'ataqah/fida' untuk diri sendiri, boleh membacakannya untuk ahli quburnya yang sudah meninggal dunia. Sebagaimana firman Allah SWT:

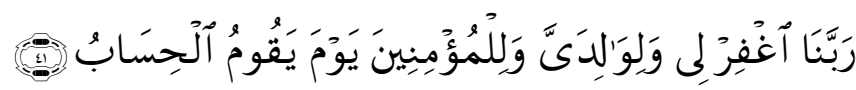

"Ya Tuhan Kami, beri ampunlah aku dan kedua ibu bapaku dan sekalian orang-orang mukmin pada hari terjadinya hisab (hari kiamat)."60

\section{Istighatsah}

Istighatsah maksudnya adalah meminta pertolongan kepada Allah SWT dalam segala hal, termasuk agar mencapai kemenangan dalam menghadapi musuh-musuh-Nya. Esensi istighatsah adalah berdoa, tetapi biasanya dilakukan dengan berdoa bersama membaca serangkaian bacaan dhikir yang

\footnotetext{
57 Zamraji Saeraji, al-Tadhkirat al-Nafi'at fi Silsilah al-Thariqah al-Qadiriyyah wa Naqshabandiyyah, Jilid II (Pare: tp., 1986), 4

58 Isma'il Ibnu M. Sa'id al-Qadiri, al-Fuyudhat al-Rabbaniyyah fi al-Ma'athir wa al-Aurad al-Qadiriyah (Kairo: Mash-had al-Husaini, tt.), 15.

${ }^{59}$ Zamraji, al-Tadhkirat, 4.

60 Al-Qur'an, 14 (Ibrahim): 41.
} 
terssusun dari ayat-ayat al-Qur'an, istighfar, shalawat Nabi, asma' al-husna, tahmid, tahlil, tasbih, takbir dan doa.

Istighatsah, pernah dicontohkan Rasulullah SAW ketika terjadi perang badar, karena melihat tentara kaum muslimin hanya berjumlah 313 orang, sedangkan kaum kafir berjumlah 1000 orang, maka Allah menurunkan bala bantuan sejumlah 1000 malaikat. Sebagaimana firman-Nya:
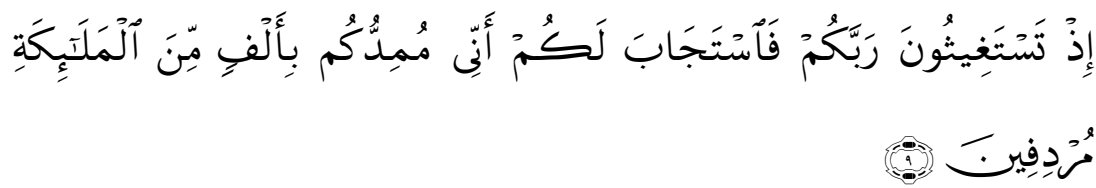

"Ingatlah ketika kamu sekalian mohon pertolongan kepada Tuhanmu, lalu diperkenankan-Nya bagimu: "Sesungguhnya aku akan mendatangkan bala bantuan kepada kamu dengan seribu Malaikat yang datang berturut-turut."61

\section{Muraqabah}

Kontemplasi atau muraqabah adalah seseorang duduk mengheningkan cipta dengan penuh kesungguhan hati, dengan penghayatan seolah-olah berhadapan dengan Allah SWT, meyakinkan hati bahwa Allah SWT senantiasa mengawasi dan memperhatikan segala perbuatannya. ${ }^{62}$ Dengan latihan muraqabah ini seseorang akan memiliki nilai ihsan yang lebih unggul, dan akan dapat merasakan kehadiran Allah kapan saja dan di mana saja ia berada.

Muraqabah memiliki perbedaan dengan dhikir terutama pada objek pemusatan kesadaran (konsentrasinya). Kalau dhikir memiliki objek perhatian pada simbul yang berupa kata atau kalimat, sedangkan muraqabah

\footnotetext{
${ }^{61}$ Al-Qur'an, 8 (al-Anfal): 9.

62 Muhammad Shadiq 'Urjun, al-Tashawwuf fi al-Islam Manabi'uh wa Athwaruh (Kairo: Mathba'ah al-Kulliyah al-Azhariyah, 1967), 39.
} 
menjaga kesadaran atas makna, sifat qudrat dan iradah Allah SWT. Demikian juga media yang digunakan memiliki perbedaan, dzikir menggunakan lidah, sedangkan muraqabah menggunakan kesadaran dan imajinasi. ${ }^{63}$

\section{Puasa}

Puasa merupakan salah satu amalan dalam pendidikan tasawuf, yaitu beberapa amalan puasa sunnah, antara lain:

a. Puasa hari Senin dan Kamis.

b. Puasa hari 'arafah, yaitu puasa pada tanggal 9 bulan Dhul Hijjah.

c. Puasa hari 'ashura', yaitu puasa tanggal sepuluh bulan Muharram.

Sebagaimana sabda Nabi Muhammad SAW. :

ان رسول الله صل الله عليه وسلم سئل عن صوم يوم عرفة فقال " يكفر السنة الماضية والباقية " و سئل عن صوم يوم عاشوراء. فقال " يكفر السنة الماضية " و سئل عن صوم يوم الاثننين فقال : ذالك يوم ولدت فيه وبعثت فيه وانزل علي فيه. "Sesungguhnya Rasulullah SAW ditanya tentang puasa hari 'Arafah, dia bersabda: Dapat menghapus dosa setahun yang lalu dan setahun yang akan datang. Dan ditanya tentang puasa hari 'Ashura', dia bersabda: dapat menghapus dosa setahun yang lalu. Dan ditanya tentang puasa hari Senin, dia bersabda: hari itu adalah hari aku dilahirkan, dan aku diutus menjadi Rasul dan hari diturunkan wahyu kepadaku."64

63 Kharisudin Aqib, Tarekat Qadiriyah \& Naqsyabandiyah Suryalaya: Studi tentang Tazkiyatun Nafs sebagai Metode Penyadaran Diri, Disertasi (Jakarta: IAIN Syarif Hidayatullah,2001), 117.

64 Imam Muslim, Shahih Muslim, 346. 
d. Puasa enam hari di bulan Syawwal.

Berdasarkan sabda Nabi Muhammad SAW.

من صام رمضان ثم اتبعه ستا من شوال كان كصيام الدهر. رواه مسلم.

"Barang siapa puasa Ramadhan kemudian diiringi dengan puasa enam hari pada bulan Syawal, maka seperti puasa setahun."65

e. Puasa tiga hari setiap bulan pada tanggal tiga belas, empat belas dan lima belas hijriyah. Sebagaimana sabda Nabi Muhammad SAW:

$$
\text { عشرة واربع عشرة وخمس عشرة الله صل الله عليه وسلم ان نصوم من الشهر ثلاثة ايام : ثلاث النسائ والترمذى وصححه ابن حبان. }
$$

"Rasulullah SAW memerintah kami agar berpuasa tiga hari dalam sebulan, yaitu tigabelas, empatbelas dan limabelas (bulan hijriyah)."66

f. Puasa di bulan Sha'ban.

Berdasarkan sabda nabi Muhammad SAW:

كان رسول الله صل الله عليه وسلم يصوم حتى نقول لايفطر ويفطر حتى نقول لا يصوم. وما رايت رسول الله صل الله عليه وسلم استكمل صيام شهر قط الا رمضان. وما رايته في شهر اكثر منه صياما فن شعبان. متفق عليه

"Adalah Rasul SAW berpuasa, hingga kami mengira tidak akan berbuka, dan beliau tidak berpuasa sehingga kami mengira tidak akaan berpuasa, daan aku tidak pernah melihat Rasul SAW berpuasa sebulan penuh, kecuali pada bulan ramadhan, dan aku tidak melihat beliau berpuasa

65 Imam Muslim, Shahih Muslim, 348.

66 Imam Muslim, Shahih Muslim, 347. 
dalam sebulan yang lebih banyak dari puasanya di bulan Sya'ban."67

\section{Signifikansi Maqamat dan Amalan-amalan pada Pendidikan Tasawuf dalam Perubahan Perilaku Manusia.}

Maqamat atau tahapan-tahapan pada pendidikan tasawuf yang terdiri dari taubat, istiqamah, zuhud, qana'ah dan raja' dilaksanakan di bawah bimbingan seorang guru/murshid dalam kehidupan sehari hari secara terus menerus, menjadikan murid diampuni dosanya oleh Allah SWT karena senantiasa bertaubat, terbiasa hidup disiplin, teguh pendidirian, rajin beribadah karena menerapkan istiqamah, mengutamakan Allah SWT dan kehidupan akhirat karena melaksanakan zuhud, menerima dengan senang hati segala pemberian Allah SWT kepadanya dengan qana'ah dan senantiasa berharap atas rahmat Allah SWT dengan menerapkan raja'.

Amalan-amalan pada pendidikan tasawuf dengan maqamat ini saling berkaitan satu dengan lainnya. Hal yang berkaitan dengan taubat adalah istighfar atau permohonan ampun kepada Allah SWT dan 'ataqah / fida' ya'ni pemerdakaan dan penebusan diri dari dosa. Hal yang berhubungan dengan istiqamah adalah dhikir, shalawat Nabi, hizib dan istighatsah karena pelaksanaannya setelah shalat fardhu dan shalat malam. Hal ini merupakan pembiasaan yang kuat. Sesuatu yang sudah terbiasa maka akan sulit atau berat untuk meninggalkannya. Muraqabah dan puasa merupakan amalan pendekatan diri kepada Allah SWT yang dapat melahirkan qana'ah, zuhud dan raja'.

Tahapan-tahapan atau maqamat dan amalan-amalan pada pendidikan tasawuf yang diajarkan, dibimbing, dibina,

67 Imam Bukhari, Shahih Bukhari, 414. 
dan dilatih oleh seorang guru/murshid dengan disiplin, mampu merubah mindset seseorang dari kecenderungan pada dunia menuju kecenderungan pada akhirat, dari kecenderungan pada penurutan hawa nafsu menuju kecenderungan pada ketaatan kepada Allah SWT.

Hal ini terjadi karena adanya motivasi atau dorongan. Motivasi itu sendiri menurut Glaiman adalah pemasok daya (energizer) untuk bertingkah laku secara terarah. ${ }^{68}$ Motivasi berfungsi sebagai pendorong perbuatan, sebagai penggerak perbuatan, sebagai pengarah perbuatan dan sebagai penguatan bersemayamnya segala informasi dalam memori seorang.

Adanya motivasi yang ditumbuhkan, ditanamkan dan dikembangkan oleh guru/murshid terhadap muridnya dalam proses pendidikan tasawuf ini merupakan pendorong, penggerak, pengarah dan penguatan terhadap penguasaan dan semangat pengamalan ajaran-ajaran tasawuf dalam kehidupan seorang murid.

Maqamat dan amalan-amalan pada pendidikan tasawuf yang disertai dengan motivasi yang kuat, dapat melahirkan tingkah laku manusia yang cenderung baik dan terpuji. Menurut Imam Ghazali, tingkah laku terpuji itu disebabkan atas tiga faktor pendorong, yaitu:

1. Pendorong ke arah kebutuhan akan penghargaan yang berupa perolehan pahala dan surga dari Allah SWT.

2. Pendorong ke arah kebutuhan akan sanjungan dari Allah SWT.

3. Pendorong ke arah kebutuhan akan keridhaan Allah SWT dan kedekatan dengan-Nya. ${ }^{69}$

\footnotetext{
68 Muhibbin Syah, Psikologi Belajar (Jakarta: P.T. Gravindo Persada, 2003), 151. 69 Imam Ghazali, Mizan al-'Amal (Beirut: Dar al-Kutub al-Ilmiyah, 1989), 93. 


\section{E. Penutup}

Dari uraian diatas dapat simpulkan bahwa maqamat berupa taubat, istiqamah, zuhud, qana'ah, raja' dan amalanamalan pada pendidikan tasawuf berupa istighfar, dhikir, shalawat Nabi, hizib, 'ataqah, istighatsah, muraqabah dan puasa yang dibimbing, diajar, dibina dan dilatih oleh guru/ murshid dapat merubah mindset seseorang. Melalui motivasi yang ditumbuhkan, ditanamkan dan dikembangkan oleh guru/ murshid kepada murid serta adanya kebutuhan-kebutuhan akan pahala, surga, sanjungan, keridhaan dan kedekatan dengan Allah SWT, merupakan pendorong dan penggerak untuk bertingkah laku sebagaimana yang diajarkan oleh guru/ murshid; antara lain mengutamakan kepentingan akhirat, memerangi hawa nafsu, taat pada Allah SWT.

\section{DAFTAR PUSTAKA}

\section{Al-Qur'an al-Karim}

Abu al-Qasim 'Abd al- Karim al Qushairy, Risalah al-Qushairiyah (Kairo: Dar al-Khair, tt).

'Abd al-Khaliq al-Hilali, Durrah al-Salikin fi Dhikr al-Silsilah alThariqah al-Syadhiliyah al-Mu'tabarah (tp.: tt., 1980).

'Abd al-Halim Mahmud, al-Madrasah al-Syadhaliyyah (Mesir: Dar al-Kutub al-Hadithah, 1968).

Al-Jami' al-Shaghir, Juz I.

'Abd al-Wahab al-Sha'rani, Minah al-Saniyyah (Surabaya: alHidayah, tt.).

'Abdul Qadir 'Isa, Hakikat Tasawuf ( Jakarta: Qisthi Press, 2005). Al-Sarraj, al-Luma' fi al-Tashawwuf (Kairo: Dar al-Kutub alHadithah,1960). 
'Ali Hasan al-'Aridh, Bahjat al-Nufus li Ibn 'Athaillah (Kairo: M. Taufiq Uwaudhat, 1969).

Abu 'Abbas Ahmad Zaruq al-Fasi, Qawa'id al-Tashawwuf.

Abi 'Abdillah, Dalail.

Imam Bukhari, Shahih Bukhari, Juz II (Beirut: Dar al-Kutub al'Ilmiyah, 2005).

Imam Bukhari, Shahih Bukhari, Juz IV ( Beirut: Dar al-Kutub al 'Ilmiyah, 2005).

Imam Muslim, Shahih Muslim, Juz II (Mesir: Isa al-Babi al-Halibi, tt.).

Imam Turmudzi, Sunan Turmudzi (Beirut: Dar al-Fikr,1980).

Imam Tirmidzi, Sunan al-Tirmidzi (Beirut: Dar Ibnu Hazm, 2002).

Ibn 'Athaillah, Al-Hikam, terj. Salim Bahraish dengan judul terjemah al-Hikam, Pendekatan Abdi pada Khaliqnya (Surabaya: Balai Buku, 1984).

Ibn 'Athaillah, Miftah al-Faidh wa Misbah al-Arwah (Mesir: Maktabah Muhammad Ali al-Shabi wa Awladih, tt.).

Ibn 'Athaillah, Miftah al-Falah wa Mishbah al-Arwah (Mesir: Maktabah 'Ali Shabih wa Awladih, tt.).

Imam Ibnu Majah, Sunan Ibnu Majah, Juz I ( Beirut: Dar al-Fakr, 2004).

Isma'il Ibnu M. Sa'id al-Qadiri, al-Fuyudhat al-Rabbaniyyah fi alMa'athir wa al-Aurad al-Qadiriyah (Kairo: Mash-had alHusaini, tt.).

Imam Ghazali, Mizan al-'Amal (Beirut: Dar al-Kutub al-Ilmiyah, 1989).

Kharisudin Aqib, Tarekat Qadiriyah \& Naqsyabandiyah Suryalaya: Studi tentang Tazkiyatun Nafs sebagai Metode Penyadaran Diri, Disertasi (Jakarta: IAIN Syarif Hidayatullah,2001). Muhammad Shadiq 'Urjun, al-Tashawwuf fi al-Islam Manabi'uh wa Athwaruh (Kairo: Mathba'ah al-Kulliyah al-Azhariyah, 1967). 
Martin Van Bruinessen, Kitab Kuning, Pesantren dan Tarekat (Bandung: Mizan, 1995).

Muhammad Idris, Kamus Idris al-Marbawi, Jilid II.

Masyhuri, Fenomena Alam jin, Pengalaman Spiritual dengan Jin (Solo: CV. Aneka, 1996).

Muhibbin Syah, Psikologi Belajar (Jakarta: P.T. Gravindo Persada, 2003).

Shaykh Mas'ud Thaha, Murshid Thariqah Shahaliyah dan Pengasuh Pondok Pesantren Nurul Huda Magelang, Ceramah, Magelang, 16 November 1999.

Sayyid Ahmad Hashimi, Mukhtar al-Hadith al-Nabawiyyah (Kairo: Shirkah Nur Asia, $\mathrm{tt}$ ).

Zamraji Saeraji, al-Tadhkirat al-Nafi'at fi Silsilah al-Thariqah alQadiriyyah wa Naqshabandiyyah, Jilid II (Pare: tp., 1986). 


\title{
ACADEMIC DISHONESTY 'VERSUS' PAKTA INTEGRITAS \\ DAN PRESTISE SEKOLAH DALAM PELAKSANAAN \\ UJIAN NASIONAL
}

\author{
Achmad Zaini \\ (Dosen PAI FTK UIN Sunan Ampel)
}

\begin{abstract}
:
This article tries to elaborate the academic dishonesty vis a vis integrity pact and school prestise during the implementation of Ujian Nasional (National Examination). It has been known that National Examination is still debatable. Many disagree to do it because the final evaluation must be returned to the teachers. Whereas, government agrees to do so in order to standardize the result of teaching learning process. To guarantee fair play in the exam, all headmasters sign integrity pact. Therefore, students are motivated to study hard to pass the exam. Unfortunately, many students even their teachers and headmasters cheat in many ways to achieve high results. The background can be traced into many factors: internal and external of the students and the prestige of the schools which "must be maintained" by national and private schools.
\end{abstract}

Keywords: Ujian Nasional, Academic Dishonesty, Pakta Integritas dan Prestise Sekolah 


\section{A. Pendahuluan}

Memasuki era globalisasi dan pasar bebas, bangsa Indonesia tidak hanya membutuhkan manusia dari segi kuantitasnya saja, namun yang lebih signifikan adalah menyangkut kualitas, baik menyangkut kualitas fisik: pengetahuan (knowledge) dan kemampuan (skill) yang dimiliki, juga menyangkut kualitas nir-fisik, yaitu hal-hal yang menyangkut kecerdasan emosi dan spiritual. ${ }^{1}$

Jenjang pendidikan menengah, khususnya sekolah menengah tingkat atas, dan pendidikan tinggi, merupakan tahapan yang sangat bermakna sebagai tempat pengembangan sumber daya manusia yang potensial sekaligus menyiapkan dan menghasilkan peserta didik yang berkualitas serta dilengkapi dengan keluhuran budi pekerti yang tinggi. Hal ini sesuai dengan tujuan pendidikan nasional yang bertujuan "untuk berkembangnya potensi anak didik agar menjadi manusia yang beriman dan bertakwa kepada Tuhan Yang Maha Esa, berakhlak mulia, sehat, berilmu, cakap, kreatif, mandiri dan menjadi warga negara yang demokratis serta bertanggung jawab."2

Menilik dari tujuan pendidikan nasional tersebut di atas dapat disimpulkan bahwa kualitas manusia Indonesia seutuhnya adalah manusia Indonesia yang memiliki ciri-ciri keserasian, keselarasan dan keseimbangan antara aspek jasmaniah dan ruhaniah. Namun, tujuan yang mulia tersebut terkadang menghadapi kendala yang cukup berat untuk mewujudkannya. Salah satu kendala yang berat adalah tidak adanya kejujuran dalam proses mencapai tujuan akademik atau yang lebih dikenal dengan istilah academic dishonesty dengan

1 Emil Salim, Mencari Strategi Pengembangan Pendidikan Nasional Menjelang Abad XXI (Jakarta: Grasindo, 1991), 30.

2 UU No. 20 Tahun 2003 tentang Sistem Pendidikan nasional. 
berbagai bentuknya termasuk menyontek yang sering dilakukan oleh peserta didik tidak hanya di level dasar juga di level pendidikan tinggi, yakni di kalangan peserta didik sekolah tingkat menengah dan mahasiswa bahkan dilakukan para dosen perguruan tinggi. Ironisnya, ketidakjujuran dengan segala macam bentuknya sering bahkan menjadi "budaya" di kalangan peserta didik, termasuk di kalangan peserta didik yang sedang melaksanakan ujian nasional.

Ketidakjujuran akademik dalam pelaksanaan ujian nasional di tingkat menengah atas (SMA) lebih mencuat dibandingkan di tingkat SMP atau bahkan SD dikarenakan adanya pro-kontra di kalangan birokrat pendidikan di level Kementerian Pendidikan Nasional dengan para akademisi di perguruan tinggi. Para birokrat pendidikan di level Kementerian Pendidikan Nasional ingin menjadikan hasil Ujian Nasional (UN) tidak hanya sekedar alat evaluasi keberhasilan peserta didik dalam menempuh jenjang pendidikan di SMTA, akan tetapi hasil UN dapat dipakai sebagai alat untuk masuk perguruan tinggi sekaligus, sehingga tidak perlu ada SNMPTN.

Di pihak lain, para akademisi perguruan tinggi memandang bahwa meskipun butir-butir soal yang ada pada UN sudah cukup baik, akan tetapi pelaksanaan UN penuh dengan ketidakjujuran untuk dapat dipakai standar masuk perguruan tinggi. Tulisan ini mencoba untuk mendeskripsikan hal-hal yang terkait dengan ketidakjujuran dalam pelaksanaan UN sehingga diketahui bagaimana pola-pola yang banyak dilakukan oleh para peserta didik bahkan pihak sekolah sekalipun dalam rangka menjaga prestise sekolah.

\section{B. Pengertian Academic Dishonesty}

Sebelum penulis mendefinisikan pengertian academic dishonesty terlebih dahulu penulis ingin mengilustrasikan 
kembali kasus penjiplakan skripsi (plagiarism) oleh Ipong S. Azhari untuk memperoleh gelar doktor (S3) di UGM. Masih terasa segar di ingatan, betapa kasus yang terjadi di Kampus Bulaksumur Jogjakarta tersebut telah mencoreng dunia akademik Indonesia. Terbongkarnya kasus Ipong S. Azhari diawali laporan Mochammad Nurhasim, peneliti pada Lembaga Ilmu Pengetahuan Indonesia (LIPI) ke Lembaga Senat UGM dan surat terbuka ke berbagai media massa.

Dalam suratnya tersebut, Mochammad Nurhasim menyatakan bahwa disertasi Ipong S. Azhari yang diterbitkan dengan Judul "Radikalisme Petani Masa Orde Baru: Kasus Sengketa Tanah Jenggawah pada pertengahan 1999" sama persis dengan skripsinya yang dipertahankan untuk memperoleh gelar sarjana (S1) di Universitas Airlangga. Setelah diadakan penelitian oleh tim, pada akhirnya Forum Senat Universitas Gadjah Mada (UGM) yang dihadiri 102 anggota senat pada tanggal 25 Maret 2000 membatalkan gelar doktor pada Ipong S. Azhari. Hal yang menarik, ternyata hampir semua data disertasi Ipong menggunakan data orang lain. Selain itu, data yang diserahkan saat ujian meraih gelar doktor tidak sama dengan disertasi yang dikumpulkan ke bagian arsip dan perpustakaan UGM. Disertasi yang diserahkan kepada penguji tidak menyebutkan sumbernya. Sementara, salinan disertasi yang diserahkan ke bagian arsip perpustakaan sudah mencantumkan sumber referensinya, yakni skripsi Mochammad Nurhasim. ${ }^{3}$

Kasus yang terjadi pada Ipong S. Azhari merupakan salah satu contoh dari kasus ketidakjujuran dalam dunia akademik. Kasus serupa sebagaimana kasus pada Ipong S.

\footnotetext{
${ }^{3}$ Baca Hadi Nur, "Eika Sains; Aspek penting dalam Riset dan Pendidikan Tinggi di Indonesia," di Internet dengan alamat http://www.angelfire.com/mt/ hadinur/diskusi3.htm;Baca juga Majalah GAMMA No. 06-2-04-04-2000.
} 
Azhari sebenarnya banyak juga terjadi tidak hanya di Indonesia, tetapi juga terjadi di belahan dunia lainnya. Kasus terakhir yang menghebohkan dunia akademik Indonesia adalah pencurian ide yang dilakukan oleh salah seorang profesor dari Universitas Parahyangan. Profesor dalam bidang Hubungan Internasional yang masih muda dan cukup produktif tersebut akhirnya diproses terkait dengan academic dishonesty dan terancam dicabut gelar akademiknya.

Di level sekolah menengah bahkan di sekolah di level bawahnya sering juga terjadi kecurangan. Salah satu bentuk kecurangan yang dilakukan dan menjadi sorotan semua pihak adalah kecurangan dalam pelaksanaan ujian nasional. Pada tahun 2009, ada sebuah sekolah SMAN di daerah tapal kuda yang seluruh jawaban peserta didiknya sama, bahkan di salah satu sekolah di daerah Mataraman dengan terpaksa pelaksanaan UN diulang kembali karena sejak awal sampai akhir pelaksanaan ujian jawaban peserta didik sama semua, sama dalam arti jumlah yang benar dan yang salah sama serta nomor item soal yang benar dan yang salah sama juga.

Wujud ketidakjujuran akademik sering juga terjadi di kalangan peserta didik yang memperebutkan bangku di perguruan tinggi. Istilah "joki" sering muncul ketika SNMPTN dilaksanakan. Mereka akan menempuh jalan apapun asalkan mereka diterima di bangku kuliah yang menjadi idaman peserta didik SMA yang akan melanjutkan studi di tingkat lebih lanjut. Bahkan yang lebih tragis ketidakjujuran terjadi tidak hanya di kalangan peserta didik tetapi juga melibatkan guru dan pengawas sekolah di suatu daerah yang konon demi menjaga prestise daerah, mereka saling "bahu-membahu" melakukan ketidakjujuran dengan jalan memberikan kunci jawaban kepada peserta didik yang sedang mengikuti UN. 
Kasus yang terdeskripsikan di atas adalah salah satu bentuk ketidakjujuran dalam dunia akademik (academic dishonesty). Mereka yang telah melakukan penipuan saintifik, yakni usaha memanipulasi fakta-fakta atau menerbitkan hasil kerja orang lain secara sengaja dengan menyembunyikan sumber aslinya. Academic Dishonesty yang dilakukan oleh kebanyakan peserta didik sebagaimana paparan di atas dapat diartikan "to gain an unfair adventage by deception or breaking rules, especially in games and examinations," (untuk memperoleh keuntungan secara tidak fair dengan jalan menipu atau melanggar peraturan, terutama dalam permainan dan ujian). ${ }^{4}$

Bahkan definisi sebagaimana di atas mengalami perluasan makna menjadi "copying from books and assignments set in previous years, collusion amongst students in preparing assignments, getting assistance from relatives, using illegal notes and copying in tests in relaxed classroom setting" (menyalin dari buku dan tugas-tugas pada tahun sebelumnya, kolusi di antara peserta didik dalam menyiapkan tugas, mendapatkan bantuan dari teman atau keluarganya, menggunakan catatan ilegal dan menyontoh/menyalin jawaban pada waktu ujian dalam seting kelas yang longgar), 5 dan "using crib notes on an exam, copying answer from another student's paper, letting other copy a homework paper, plagiarizing and ghostwriting" (menggunakan catatan ilegal pada waktu ujian, menyalin jawaban dari teman

${ }^{4}$ Concise Oxford Dictionary, Thompson, 1995.

5 John R. Godfrey dan Russell F. Waugh, "The Perception of Student from Religious Schools about Academic Dishosnesty," dalam Issues in Educational Research, 8 (2), 1998: 95. Artikel bisa diakses melalui internet: http://education.curtin.edu.au/iier8/godfrey.html 
lainnya, mempersilahkan teman lainnya menyalin pekerjaan rumah, plagiat dan tulisan yang tersamarkan). ${ }^{6}$

Sedangkan menurut Kamus Umum Bahasa Indonesia karangan W.J.S Purwadarminta yang dipertegas lagi dalam Kamus Besar Bahasa Indonesia yang dikeluarkan Depdikbud definisi menyontek atau menjiplak atau ngerpek adalah mencontoh/meniru/mengutip tulisan, pekerjaan orang lain sebagaimana aslinya. ${ }^{7}$ Adapun menurut James S. Congelosi dalam bukunya Merancang Tes untuk menilai Prestasi Peserta didik, menyontek adalah "mengutip, mencontoh, meniru pekerjaan orang lain tanpa ijin; membuang sebagian halaman tes; mencuri soal ujian, hanya menghafalkan jawaban teman dari jenis tes yang sama di kelas lain; menyembunyikan lembar contekan; mengisi jawaban setelah lembar jawaban dikembalikan; meminta bantuan teman; menyembunyikan lembar contekan di kamar kecil; mencari kertas karbon bekas."8 Dari definisi yang disebutkan di atas jelas bahwa menyontek sebagai bagian dari academic dishonesty adalah setiap tindakan yang dilakukan oleh peserta didik secara tidak jujur dalam ujian maupun dalam mengerjakan tugas-tugas yang diberikan dalam mencapai hasil atau prestasi yang baik.

Ketidakjujuran akademik menjadi "common enemy" yang harus dilawan dan diberantas. Hal ini tentunya tidak lepas dari tujuan pendidikan yang ingin dikembangkan oleh semua institusi pendidikan, yakni peserta didik yang mempunyai integritas keilmuan yang jujur, disiplin, bertanggung jawab dan

${ }^{6}$ Bushway and Nash, 1977, 623 dalam John R. Godfrey and Russell F. Wough, "The Perception of Students from Religious Schools about Academic Dishonesty," Issues in Educational Research.

7 Departemen Pendidikan dan Kebudayaan, Kamus Bahasa Indonesia (Jakarta: Balai Pustaka, 1996), 403.

8 James S. Cogelasi, Merancang Tes untuk Menilai Prestasi Peserta didik (Bandung: ITB, 1995), 56-57. 
sportif dalam melaporkan proses pembelajaran dalam rangka mencapai tujuan yang telah ditetapkan oleh sebuah institusi.

\section{Faktor-faktor Penyebab Academic Dishonesty}

Faktor-faktor yang menyebabkan terjadinya ketidakjujuran saintifik atau akademik disinyalir oleh Hadi Nur dilandasi oleh tiga hal. Pertama, tekanan karir, dimana untuk melancarkan karir, seseorang terpaksa untuk melakukan penipuan. Tekanan ini dapat terlihat bagi para peserta didik program doktor di Jepang yang rata-rata harus mempunyai publikasi di jurnal dalam bidangnya untuk memperoleh gelar doktor. Atau adanya program sertifikasi bagi guru memaksa mereka untuk melakukan ketidakjujuran akademik dengan membeli sertifikat demi tercapainya kelulusan sertifikasi tersebut. Kedua, mengetahui atau berusaha menjawab pertanyaan dari riset tanpa susah payah melakukan eksperimen yang memakan waktu dan tenaga di laboratorium. Ketiga, diulang (reproducible). Hal ini dapat menjelaskan mengapa penipuan saintifik banyak terjadi pada bidang biologi dan biomedik, karena sulit mendapatkan data-data yang betulbetul bisa diulang, karena tergantung kepada banyak faktor yang susah dikontrol.

Tiga hal yang memotivasi seseorang untuk melakukan penipuan saintifik, nampaknya dilatarbelakangi oleh pengalaman Hadi Nur yang melanjutkan studi di Jepang dan bergelut dalam bidang eksakta yang lebih banyak menghabiskan waktunya di laboratorium. 
Menurut A. Hope $\mathrm{MA}^{9}{ }^{9}$ faktor-faktor yang dapat menyebabkan kebiasaan menyontek di kalangan peserta didik adalah sebagai berikut.

1. Faktor utama adalah tekanan yang terlalu besar yang diberikan kepada hasil studi yang berupa angka atau nilai yang dipelopori oleh tes, ulangan, ujian dan lain-lain. Anak yang mendapat angka tinggi mempunyai masa depan yang bisa lebih baik daripada anak lemah. Kemungkinan untuk masuk sekolah lanjutan lebih besar dan penghargaan dari orang tua dan guru terhadap anak yang berhasil dengan angka tinggi tentu mendorong anak untuk memperoleh nilai tersebut walaupun dengan cara-cara yang tidak dibenarkan, seperti menyontek, menyalin pekerjaan temannya, mengubah nilai pada kertas ulangan, dan sebagainya.

2. Pendidikan moril, baik di rumah maupun di dalam sekolah kurang diterapkan kedalam kehidupan anak-anak, sehingga kemampuan untuk membedakan antara tindakan yang benar dan tindakan yang salah kurang dikembangkan.

3. Kebiasaan menyontek lebih sering dilakukan oleh peserta didik yang kurang rajin belajar atau mereka yang menghadapi kesulitan belajar.

4. Anak remaja lebih sering menyontek daripada anak SD. Mungkin ini disebabkan karena bagi mereka populer di kalangan teman-temannya.

5. Ada peserta didik yang memandang menyontek sebagai kesempatan untuk melanggar peraturan sekolah atau untuk memberontak terhadap penguasa.

${ }^{9}$ A. Hope MA, Kebiasaan Nyontek adalah Musuh Perkembangan Anak (Jakarta: Rajawali, 1992), 87-89. 
Secara umum faktor-faktor yang menyebabkan peserta didik melakukan ketidakjujuran akademik (misal: menyontek) dapat diklasifikasikan menjadi dua, yaitu faktor eksternal dan faktor internal. ${ }^{10}$

\section{Faktor Eksternal}

Faktor eksternal yang menyebabkan terjadinya menyontek adalah faktor kesempatan. Dalam Pengantar Kriminologi dan Patologi Sosial11 dinyatakan bahwa adanya kecenderungan manusia untuk melakukan kejahatan apabila mereka dalam situasi kritis dan ada kesempatan untuk melakukannya. Ada beberapa teori yang menjelaskan kenapa manusia mempunyai kecenderungan untuk melakukan kejahatan, termasuk dalam dunia pendidikan yang wujudnya adalah academic dishonesty. "Closure Theory" yang dikemukakan oleh Prof. Edwin H. Lemert menjelaskan bahwa dalam usahanya mempelajari masalah-masalah pemalsu, nampak ada tipe naïve forgery. Mereka adalah orang-orang yang berada dalam situasi krisis. Situasi ini mereka pecahkan dengan membuat pemalsuan. ${ }^{12}$

Di samping faktor tersebut di atas, faktor lingkungan sekitar juga mempengaruhi seseorang untuk melakukan tindak kejahatan, begitu juga sebaliknya. Menurut Sosiologis kriminal, salah satu faktor yang memotivasi lahirnya kejahatan adalah lingkungan. ${ }^{13}$ Menurut Madzhab Lingkungan, kejahatan adalah gejala sosiologis, bukan gejala patologis. Orang berbuat jahat itu terjadi karena sifat

\footnotetext{
${ }^{10}$ Lihat Imam Haryanto, "Bahaya Menyontek di Kalangan Peserta didik," Pikiran Rakyat 18 Nopember 1985, hal. 7.

11 Lebih Lengkap baca B. Simandjuntak, Pengantar Kriminologi dan Patologi Sosial (Bandung: Tarsito, 1981)

12 Simandjuntak, Pengantar Kriminologi ..., 240.

13 Simandjuntak, Pengantar Kriminologi..., 178.
} 
meniru. ${ }^{14}$ Madzhab ini menolak pandangan Lambroso, salah seorang pengikut madzhab Antropologi yang meyakini bahwa "manusia lahir telah ditakdirkan sebagai penjahat." Tesis yang dianut madzhab antropologi ini diruntuhkan dengan penelitian ilmiah yang melibatkan sampel penelitian sebanyak 100 orang penjahat dengan 100 orang yang bukan penjahat. Hasil penelitian ini meruntuhkan tesis Lambroso.

Wilbert J. McKeachie menyatakan bahwa "the pressure for good grades are so intense that many students feel that they, too, must cheat if they belive that other students are cheating ${ }^{15}$ (tekanan untuk mendapatkan nilai begitu intensnya menekan peserta didik sehingga banyak peserta didik merasa bahwa mereka juga harus menyontek jika mereka yakin bahwa peserta didik lainnya juga melakukan perbuatan menyontek)." Apa yang dikatakan McKeachie menunjukkan bahwa masih ditemukan kasus-kasus peserta didik yang tidak fair dalam memperoleh prestasi, khususnya nilai. Peserta didik yang berupaya jujur ternyata hanya dapat nilai cukup, sedang mereka yang menyontek dapat memperoleh nilai baik bahkan sangat bagus. Ketidakjujuran segelintir siwa pada akhirnya juga mempengaruhi peserta didik lainnya kecuali memperoleh prestasi yang sebaik-baiknya walupun dilakukan dengan jalan yang tidak fair.

Di samping faktor tersebut di atas, hal eksternal yang berkaitan langsung dengan faktor penyebab seorang peserta didik melakukan nyontek adalah tata ruang waktu ujian. Lokasi yang sempit dan jarak antar kursi yang begitu

\footnotetext{
14 Simandjuntak, Pengantar Kriminologi ..., 164.

15 Wilbert J. McKeachie, Teaching Tips (Lexington: DC Heath Company, 1994), 95.
} 
dekat juga mempengaruhi seseorang untuk melakukan ketidakjujuran akademik melalui menyontek atau bertanya kepada teman di sebelahnya. Berdasarkan pengalamannya, McKeachie mengatakan bahwa "the most common form of cheating is copying from another student's paper. To reduce this, I usually ask to have a large enough exam room to enable students to sit in alternate seats. I write on the board befero students arrive."16

\section{Faktor Internal}

Faktor internal yang mempengaruhi peserta didik untuk melakukan nyontek lebih bersifat psikolog (kejiwaan), antara lain dorongan kompetisi, perasaan takut, perasaan sedih dan sebagainya. Dorongan kompetisi merupakan salah satu dari dorongan-dorongan psikis yang dipelajari seseorang dari kebudayaan dimana ia hidup. Pendidikan dan pengalaman yang diterima seseorang akan mengantarkannya pada aspek-aspek dimana kompetisi dipandang baik demi kemajuan dan perkembangannya dan sesuai dengan nilai-nilai yang dipegangi oleh masyarakat dimana seseorang itu hidup.

Al-Qur'an sendiri memberikan dorongan pada manusia untuk berkompetisi dalam bertaqwa kepada Allah SWT, berbuat kebajikan, berpegang teguh pada nilai-nilai manusiawi yang luhur, dan mengikuti metode ilahi dalam kehidupan, baik dalam hubungan mereka dengan Allah SWT, dalam hubungan kekeluargaan atau dalam hubungan mereka dengan masyarakat, agar mereka bisa mendapatkan karunia dari Allah SWT. Banyak sekali ayat Al-Qur'an yang menyarankan kepada manusia untuk selalu berkompetisi dalam semua hal kebajikan, seperti QS al-

16 Wilbert J. McKeachie, Teaching Tips, 97. 
Maidah: 48 yang artinya :"Maka berlomba-lombalah berbuat kebajikan. Hanya kepada Allah-lah kamu semuanya kembali, lalu diberitahukan-Nya kepadamu apa yang telah kamu perselisihkan itu."

Dalam QS al-Baqarah: 148, Allah SWT berfirman: "Dan bagi tiap-tiap orang ada tujuan (sendiri) yang diarahnya. Maka berlomba-lombalah kamu (dalam berbuat) kebaikan..." Namun, dorongan untuk berkompetisi yang seharusnya dimiliki oleh peserta didik untuk hal-hal yang baik, malah disalahgunakan untuk mencapai hasil baik tanpa harus bekerja keras. Peserta didik yang seharusnya banyak menggunakan waktunya untuk belajar, Kenyataannya sebaliknya. Demikian juga dengan faktor psikis lainnya, misalnya, perasaan takut tidak lulus, nilainya jelek, ingin dipuji dan sebagainya juga mempengaruhi seseorang untuk melakukan hal-hal yang tidak baik.

Seharusnya perasaan-perasaan psikis tersebut disikapi secara positif. Seorang peserta didik atau peserta didik yang ingin mendapatkan prestasi yang baik maka dia harus melakukan sebuah proses yang panjang. Dia harus banyak meluangkan waktu ke perpustakaan, banyak membaca, berdiskusi dan sebagainya dalam rangka mendapatkan prestasi yang baik. Bukan sebaliknya, seorang peserta didik inginnya santai melulu, waktu yang digunakan untuk belajar sangat minim dibanding dengan kegiatan lainnya, tapi ingin mendapat prestasi yang baik. Maka, tidak ada jalan lain bagi peserta didik tipe kedua tersebut kecuali melakukan hal-hal yang tidak fair.

Pada dasarnya pergumulan aspek kejiwaan mendorong peserta didik untuk melakukan apa saja agar hasrat dan keinginan untuk mencapai yang terbaik dapat diraih walau jalan yang ditempuh keliru atau keluar dari 
rel-rel yang sudah ditentukan. Kedua faktor tersebut saling berpengaruh terhadap diri peserta didik dalam melakukan kegiatan academic dishonesty (menyontek).

\section{Pakta Integritas vis a avis Academic Dishonesty dan Prestise Sekolah}

Pelaksanaan ujian nasional di level sekolah menengah atas menjadi perhatian yang luar biasa karena diharapkan ujian nasional dapat berjalan dengan fair dan sejujur-jujurnya. Untuk mengantisipasi ketidakjujuran tersebut, Kementerian Pendidikan Nasional dan BNSP sepakat melibatkan perguruan tinggi untuk mengawasi pelaksanaan UN. Di samping itu, semua pelaksana UN menandatangani pakta integritas yang menyatakan akan melaksanakan UN dengan sejujur-jurunya.

Meski ada pakta integritas, namun disinyalir bahwa pelaksanaan UN masih mengalami ketidakjujuran. Ketidakjujuran pelaksanaan UN setidaknya, sebagaimana penjelasan di atas, dipengaruhi oleh dua faktor, yaitu eksternal dan internal. Faktor eksternal, ada target daerah (provinsi) yang mematok bahwa tingkat kelulusan peserta didik sebuah provinsi harus mencapai porsentase tertentu. Hal ini biasanya dipahami oleh kepala dinas sebagai sebuah perintah atasan yang harus "diamankan" sebagai sebuah kebijakan. Kepala dinas kemudian menginstruksikan para kepala sekolah termasuk para pengawas untuk ikut mengamankan kebijakan tersebut sehingga target pimpinan tercapai. Apabila target pimpinan tidak tercapai maka konsekwensinya adalah "dicopot" dari jabatan baik sebagai kepala dinas ataupun kepala sekolah.

Hal inilah yang menjadi pemicu pihak sekolah (khususnya sekolah negeri) untuk melakukan ketidakjujuran dalam pelaksanaan UN. Bagi para kepala sekolah swasta atau yayasan, tingkat kelulusan siswa pada UN merupakan sebuah 
taruhan eksistensi yayasan atau sekolah pada tahun berikutnya. Apabila sekolah tersebut dapat meluluskan peserta didiknya 100\%, maka sekolah tersebut akan diminati oleh masyarakat. Sebaliknya, semakin tinggi tingkat ketidaklulusannya maka sekolah tersebut akan ditinggalkan masyarakat dan akhirnya tutup. Di samping dua hal tersebut di atas, ada yang sengaja melakukan academic dishonesty karena dia memang tidak setuju dengan adanya UN. Sampai kapanpun UN dilaksanakan, dia akan tetap melakukan ketidakjujuran dalam pelaksanaannya.

Di samping faktor eksternal, faktor internal peserta didik juga mempengaruhi ketidakjujuran dalam pelaksanaan UN. Ketidaksiapan peserta didik disebabkan antara lain mengharapkan dapat jawaban dari gurunya atau temannya berdasarkan pengalaman tahun sebelumnya sehingga mereka malas untuk belajar.

Pola-pola yang digunakan dalam melaksanakan ketidakjujuran UNAS dapat diklasifikasikan dalam 2 hal saja, yaitu:

1. Sekolah membentuk tim sukses

Tim sukses yang dibentuk oleh sekolah ini dapat dibagi dalam 2 kelompok dalam menjalankan modus operandinya, yaitu:

a) Memberikan jawaban kepada siswa secara langsung Sekolah biasanya membentuk tim guru yang mata pelajarannya di-UN-kan. Hal ini dimungkinkan karena jeda waktu pengambilan naskah di polsek dengan pelaksanaan UN relatif cukup lama (kurang lebih 3 jam) dan biasanya tidak ada pengawalan baik dari pihak kepolisian maupun dari tim independen. Tidak adanya pengawasan dari kepolisian dikarenakan jumlah personil dari kepolisian tidak mencukupi untuk mendampingi setiap sekolah yang mengambil soal ujian 
nasional. Tim independen yang dibentuk oleh perguruan tinggi dan BNSP juga tidak sampai menyentuh pada pengawasan pengambilan soal dari polsek sampai sekolah.

Waktu itu jeda yang cukup lama tersebut dapat "dimanfaatkan" oleh para oknum untuk melakukan kecurangan dengan membuka segel yang mudah untuk dikembalikan sebagaimana kondisi semula. Di samping membuka segel dan mengambil soal kemudain dikerjakan, ada juga pola yang digunakan oleh pihak sekolah untuk mengerjakan soal unas ketika berlangsung, yaitu memanfaatkan soal cadangan yang jarang sekali diperhatikan keberadaanya. Ketika peserta didik mengerjakan soal unas, tim sukses sekolah juga mengerjakan di suatu ruang di sekolah tersebut. 30 menit sebelum jatah waktu habis, jawaban sudah terdistribusi secara merata ke seluruh siswa. ${ }^{17}$ Memang sulit membuktikan sebab tidak ada bukti bahkan pengawas dari perguruan tinggi juga tidak mengetahui adanya kecurangan ketika pelaksanaan unas berlangsung.

b) Membetulkan jawaban siswa pasca-UN

Pola kedua yang digunakan adalah membetulkan lembar jawaban peserta didik. Pola ini dilakukan ketika waktu pelaksanaan unas berakhir tiap harinya, lembar jawaban dibawa ke sebuah ruang khusus. Di sanalah tim sukses bekerja membenahi jawaban siswa yang salah. Pengawaas dan tim independen "dijamu" sedemikian rupa sehingga mereka tidak boleh mendekat ke ruang yang dipakai untuk melakukan

17 Hasil investigasi tim pengawas di sebuah SMAN di daerah tapal kuda. 
ketidakjujuran tersebut. Pola ini sudah banyak ditinggalkan karena mudah untuk dideteksi.

c) Usaha siswa sendiri

Di samping mengandalkan pemberian jawaban dari tim sukses sekolah, peserta didik sekarang ini lebih proaktif mencari "bocoran" jawaban unas. Tentunya bocoran ini tidak gratis. Mereka harus membayar sampai dengan 4 juta rupiah untuk mendapatkan jawaban keseluruhan mata pelajaran yang diunaskan. ${ }^{18}$ Untuk membayar harga tersebut biasanya ada "pengepul" tiap sekolah untuk membeli secara bersama-sama (patungan).

Menurut informasi yang penulis terima adalah jawaban tersebut sudah diterima oleh siswa 3 hari sebelum pelaksanaan berlangsung dan didistribusikan lewat sms. Penjelasan seorang siswa yang menjadi "pengepul" tersebut dikuatkan salah seorang guru yang merangkap guru di sebuah lembaga bantuan belajar. Hal yang cukup mengherankan adalah pihak kepolisian mengidentifikasi bawah jawaban yang diberikan via sms tersebut 99 benar, meskipun pihak koordinator UN di Jawa Timur, ITS, masih menyangsikan kebenaran jawaban tersebut sebab yang tahu jawaban persis tiap mata pelajaran adalah BNSP.

\footnotetext{
18 Hasil inverstigasi penulis kepada salah seorang siswa. Penjelasan siswa ini dibenarkan dan dikuatkan oleh seorang guru yang merangkap tutor di sebuah lembaga bantuan belajar yang mengetahui adanya pertemuan di sebuah hotel untuk mengerjakan soal-soal unas tersebut yang kemudian dijual dengan harga yang cukup tinggi.
} 


\section{E. Penutup}

Tujuan pelaksanaan UN sebagai bentuk evaluasi belajar merupakan upaya pemerintah untuk menstandarkan lulusan baik di level dasar maupun menengah. Upaya ini menimbulkan pro dan kontra tidak hanya di kalangan akademisi, birokrat bahkan di akar rumput sekalipun. Terlepas dari pro dan kontra, UN tetap dilaksanakan dan masih menyisakan permasalahan yang cukup krusial, yaitu masih adanya kecurangan atau ketidakjujuran dalam pelaksanaannya. Pakta integritas yang ditandatangani bahkan disumpahkan tinggallah pakta integritas ketika berhadapan dengan kepentingan yang dianggap lebih besar oleh para oknum, misalnya, taruhan jabatan di sebuah instansi atau sekolah, dan/atau sebuah prestise sekolah supaya tetap eksis sehingga apapun dilakukan termasuk academic dishonesty yang terkadang diatur lebih sistematis sehingga sulit untuk dideteksi keberadaannya.

\section{DAFTAR PUSTAKA}

A. Hope MA, Kebiasaan Nyontek adalah Musuh Perkembangan Anak (Jakarta: Rajawali, 1992).

B. Simandjuntak, Pengantar Kriminologi dan Patologi Sosial (Bandung: Tarsito, 1981)

Bushway and Nash, 1977, 623 dalam John R. Godfrey and Russell

F. Wough, "The Perception of Students from Religious Schools about Academic Dishonesty," Issues in Educational Research.

Concise Oxford Dictionary, Thompson, 1995.

Departemen Pendidikan dan Kebudayaan, Kamus Bahasa Indonesia (Jakarta: Balai Pustaka, 1996). 
Emil Salim, Mencari Strategi Pengembangan Pendidikan Nasional Menjelang Abad XXI (Jakarta: Grasindo, 1991).

Hadi Nur, "Eika Sains; Aspek penting dalam Riset dan Pendidikan Tinggi di Indonesia," di Internet dengan alamat http://www.angelfire.com/mt/hadinur/diskusi3.htm;Bac a juga Majalah GAMMA No. 06-2-04-04-2000.

Http://education.curtin.edu.au/iier8/godfrey.html

Hasil investigasi tim pengawas di sebuah SMAN di daerah tapal kuda.

Hasil inverstigasi penulis kepada salah seorang siswa.

Imam Haryanto, "Bahaya Menyontek di Kalangan Peserta didik," Pikiran Rakyat 18 Nopember 1985.

John R. Godfrey dan Russell F. Waugh, "The Perception of Student from Religious Schools about Academic Dishosnesty," dalam Issues in Educational Research, 8 (2), 1998.

James S. Cogelasi, Merancang Tes untuk Menilai Prestasi Peserta didik (Bandung: ITB, 1995).

UU No. 20 Tahun 2003 tentang Sistem Pendidikan nasional.

Wilbert J. McKeachie, Teaching Tips (Lexington: DC Heath Company, 1994). 


\title{
SUMBER BELAJAR DALAM TEORI PANCARAN (TELAAH FILOSOFIS TENTANG PENDIDIKAN)
}

\author{
Abd. Kadir \\ (Dosen PAI FTK UIN Sunan Ampel)
}

\begin{abstract}
Abstrak:
Secara luas sumber belajar merupakan pengalaman hidup yang bersifat empirik, rasional dan spiritual. Pengalaman hidup empirik didapat dari insteraksi seseorang dengan lingkungan material dan sosial, dan yang rasional dari melalui premis-premis yang dapat dipikirkan secara logis; sedangkan yang spiritual merupakan emanasi dari wujud wajib melalui akal aktif kepada Akal Mustafad. Akal yang beroperasi pada level supra mental ini memancarkan pengetahuan yang berupa bentuk tertentu kepada seseorang, karena ada kecenderungan jiwa manusia yang suci berhubungan dengan akal ini. Siapapun yang dapat berhubungan dan berkomunikasi dengan akal ini, maka ia akan mengenal atau mengetahui hakikat dari sesuatu.
\end{abstract}

Kata Kunci: Sumber Belajar dan Teori Pancaran.

\section{A. Pendahuluan}

Dalam teori-teori pendidikan dikatakan bahwa sumber belajar adalah segala sesuatu yang bisa dimanfaatkan guna kepentingan proses belajar, baik secara langsung maupun tidak langsung; sebagian atau keseluruhan dalam mencapai tujuan pembelajaran. Pengalaman seseroang adalah sumber belajar dalam arti luas, dan segala sesuatu yang dialami 
seseorang dianggap sebagai sumber belajar baik; pengalaman fisik, psikis maupun pengalaman spiritual.

Kehidupan manusia merupakan akumulasi dari berbagai pengalaman baik yang dirancang, dipersiapkan maupun yang diterima sebagaimana adanya. Kelahiran manusia ke dunia bukanlah suatu rancangan oleh dirinya sendiri tetapi dipersiapkan oleh pihak lain, dan manusia yang lahir menerima keberadaannya sebagaimana adanya, tanpa harus memilih dimana, kapan dan dari siapa ia akan dilahirkan. Namun demikian dalam kehidupan selanjutnya ia merancang dan mempersiapkan kehidupannya dengan pengalaman hidup sebagaimana ia inginkan. Walaupun demikian tidak semua keinginan hidupnya dapat diwujudkan karena ketidakmampuannya untuk mempersiapkan dan mengendalikan segala sesuatu yang berada di luar batas kemampuannya.

Dimensi fisik dan psikis manusia memang tunduk kepada hukum-hukum sebagaimana disebutkan di atas, tetapi pada aspek spiritual manusia tidak sepenuhnya mengikuti sebagaimana disebutkan tadi. Ketika manusia ingin mendekati Tuhan dalam suasana keintiman, ada usaha-usaha yang bisa dilakukan dengan berbagai macam mujahadah, riyadlah sebagai usaha tazkiyah al-nafs. Namun tidak semua usaha yang dilakukannya selalu membawa hasil, karena kedekatan dengan Tuhan yang tanpa diperantarai oleh jarak itu bukan semata usaha manusia semata, tetapi sangat bergantung kepada rahmat Tuhan yang akan dilimpahkannya. Bilamana Tuhan menghendaki seseorang untuk mendekat kepada-Nya secara intim, maka Dia menariknya ke sisi-Nya (jadzb) sehingga ia mengenal-Nya dari dekat. 


\section{B. Pengalaman Ruhaniyah sebagai Rentetan Emanasi}

Kemungkinan pendidikan melalui pencapaian pengalaman ruhaniyah bisa ditelusuri dari kosmologi penciptaannya sebagai rentetan emanasi dari sebab pertama. Proses emanatif aspek spiritual adalah limpahan atau pancaran cahaya Ilahi. Tuhan sebagai realitas sederhana, keseluruhan hakikatnya -dengan kebesaran-Nya yang memanifestasikan diri sebagai sumber wujud- sama sekali melampaui kemampuan pengenalan kognitif, serta manusia hanya membentuk gagasan-gagasan yang amat kabur dan tidak sempurna.

Gagasan-gagasan itu dengan berani ditampilkan melalui konsep bahwa Tuhan itu adalah Wajib al-Wujud (الو اجب الوجود), yaitu sesuatu yang harus ada, dan ketiadaannya menimbulkan kemustahilan. Dia tidak memerlukan identitas dan realitas yang bisa didefinisikan. Kepastian ada-Nya bisa disebabkan oleh dzat-Nya sendiri dan tidak oleh yang lain. Pemunculan dan manifestasi diri-Nya pada wujud yang lain memungkinkan kebenarannya bisa dibayangkan oleh nalar. Hanya pada Wajib al-Wujud yang esensi dan eksistensinya satu dan sama adalah kebenaran murni, sebagai ketuhanan murni dan asal segala wujud, ${ }^{1}$ sedangkan pada lain-Nya kesatuan esensi dan eksistensi hanya aksiden yang ditambahkan pada esensi. Perbedaan antara esensi dan eksistensi hanya merupakan pengenalan oleh nalar dan dalam realitasnya adalah satu dan sama. $^{2}$

Tuhan adalah azali (الازلي/tanpa permulaan) yang tidak memerlukan pada pencipta. Sifat dan dzat-Nya sesuai dengan

1 Hosen Nashr, An Introduction to Islamic Ontological Doctrines (New York: State University, 1993), 18.

2 Mir Valiudin,Tasawuf dalam Qur an, penterj: Pustaka Firdaus ( Jakarta: Pustaka Firdaus, 1993), 58. 
kekekalan-Nya tanpa memerlukan individualitas-Nya mewujudkan diri-Nya melalui cahaya-Nya dalam bentuk objek fenomena, dan sebagai entitas cerminan yang mengungkapkan hakikat-Nya yang ada dalam pengetahuan-Nya. Hal ini merupakan aspek ilahiyah yang dikaitkan dengan ciptaan fenomena. Pengetahuan tentang hakikatnya oleh diri-Nya menyebabkan sesuatu menjadi ada, sehingga pada dasarnya semua wujud yang lain berasal dari kehendak-Nya.

Wujud lain pada dasarnya bersumber pada yang satu yang dapat dilihat dari kesatuannya dan bukan dari keragamannya. Dia adalah sumber segala sesuatu; mengetahui segala sifat dan hakikat-Nya. Karena Dia disebut akal murni, maka pada saat yang sama merupakan tindak penalaran, serta sekaligus menjadi subjek dan objek nalar. Dia hanya berpikir tentang diri-Nya, dan tidak mungkin berpikir tentang realitas yang bersifat sementara dan wujud yang lebih rendah. ${ }^{3}$ Pengetahuan-Nya tentang diri-Nya sebagai sebab pengetahuanNya tentang alam semesta adalah mutlak, satu, dan sama. Maka eksistensi alam semesta adalah efek pengetahuan Tuhan tentang eksistensi tersebut, sedangkan pengetahuan tentang diri-Nya adalah wujud dzat yang diciptakannya.

Wujud selain Tuhan merupakan manifestasi dari Tuhan secara emanatif. Kepastian dari sistem emanasi sebagai suatu keharusan dan sebagai kemungkinan sebab penyerapan adalah kebergantungan secara total wujud mungkin kepada Tuhan. Suatu bentuk wujud muncul dan ditopang oleh wujud yang lain, baik dalam memasuki eksistensi maupun dalam melanjutkan eksistensi pada pihak lain di bawahnya. Hirarki emanasi itu menyiratkan kontinuitas dan kontingensi total mode emanatif yang lebih rendah pada prinsip-prinsip terdekatnya, baik yang berada dalam tingkat pertama maupun terakhir.

\footnotetext{
3 Ibid., 249.
} 
Wujud emanatif tidak pernah dilepaskan dari sumbernya dengan berdiri sendiri sebagai entitas yang mandiri. Wujud emanatif tetap eksis dalam ketergantungannya pada sumbernya. Ketergantungan murni terhadap yang lain, karena ia tidak mempunyai realitas dalam dirinya selain sebagai subordinat dari suatu realitas. Proses emanasi tidak menyerah pada kehampaan total, tetapi ada keterkaitan tak terputus antara berbagai level wujud emanatif dengan prinsip terdekatnya. ${ }^{4}$ Wujud emanatif tidak pernah mengalami perubahan substansi menjadi hakikat sumbernya, karena wujud emanatif mempunyai prinsip yang bersifat mungkin bagi dirinya sendiri.

Penciptaan kadang-kadang berarti pemberian wujud oleh Tuhan dan pemancaran cahaya dari sumber yang suci, sehingga penciptaan adalah suatu realitas dan eksistensi yang dapat dipikir sebagai tajalli (تجلى/ manifestasi) dari-Nya. Emanasi ke arah luar diserap oleh gerakan kembali kepada Tuhan. Terdapat ketersambungan/ relasi dalam rentetan emanatif antara wujud pertama dengan wujud berikutnya, sampai kepada wujud manusia. Hubungan manusia dengan Tuhan diperantarai oleh akal-akal, dari akal pertama sampai akal kesepuluh. Akal kesepuluh ini sering kali dikenal dengan sebutan malaikat Jibril (pembawa wahyu/llham) dan melimpahkannya kepada manusia secara emanatif pula.

\section{Akal Pertama}

Dalam spekulasi filosofis bahwa wujud pertama adalah esensi, sedangkan eksistensi adalah turunan atau konsep

4 Mehdi Ha'iri Yazdi, Ilmu Hudhuri, penterj.: Ahsin Muhammad (Bandung: Mizan, 1994), 223. 
mental. ${ }^{5}$ Wujud itu sebenarnya sebagai keseluruhan rangkaian kesatuan yang terdiri dari kesadaran diri dan monad ${ }^{6}$ mandiri yang tidak terpisahkan dari keseluruhan, dan dikenal oleh dirinya sendiri. Dengan jalan emanasi terjadilah penciptaan; dan wujud emanatif level teratas; dan al-'aql al-awwal العقل (الاول/ akal pertama) berada pada posisi ini. Wujud ini diidentifikasikan dengan berbagai macam nama atau sebutan, yang antara lain: al-'aql al-ula ( العقل الاولى/ akal pertama), al-'aql al-kulli (العقل الكلى / akal universal), al-malak ( الملى الملك/ malaikatmalaikat), ${ }^{7}$ cahaya abstrak, ${ }^{8}$ yang sebanding dengan intelek. ${ }^{9}$

Akal pertama atau kadang-kadang disebut dengan jiwa rasional-bersifat immaterial dan ia adalah ruh dunia. ${ }^{10}$ Dia adalah wajib al-wujud dalam dirinya sendiri atau menjadi sifat mungkin dalam esensinya, karena rahmat Tuhan. Akal ini sebagai substansi yang wujudnya tunggal, tetapi menerima bentuk dari wujud lain yang berasal dari Wajib al-Wujud yang esensi dan eksistensinya satu, yaitu kebenaran murni, dan sebagai sumber dan asal segala wujud. Jiwa rasional melalui aktivitas kesadaran diri mengkaitkan tatanan kosmik dengan

5 Ziai, Hossein, Filsafat Illuminasi, penterj.: Afif Muhammad dan Munir (Bandung: Zaman Wacana Mulia, 1988), 150.

${ }^{6}$ Monade dalam bahasa Yunani adalah monas atau satuan, yaitu satuan substansial yang bersifat tunggal tidak dapat dibagi, murni metafisik tanpa bentuk dan keluasan sebagai ciptaan Tuhan; dengan kerjanya bersifat immanen; dan mengungkapkan diri semata-mata di dalam dirinya sendiri dan oleh dirinya sendiri. Ali Mudhofir, Kamus Istilah Filsafat (Yogyakara : Liberty, 1992), 104.

${ }^{7}$ Abu Hamid Muhammad bin Muhammad al-Ghazali, Misykah al-Anwar (Kairo: Dar al-Fahm, 1964), 24-25.

8 John Tulltill, The Philosophy of Quthb al-Din al-Sirazi: a Study in Integration of Islamic Philosophy (Boston: Harvard University, 1983), 204.

${ }^{9}$ Hossein Ziai, Filsafat Illuminasi..., 80.

${ }^{10}$ Hosen Nasr, An Introduction ....., 57. 
tatanan fisik melalui prinsip kesadaran langsung dalam berbagai tingkat intensitasnya. ${ }^{11}$

Oleh karena akal pertama adalah wujud mungkin, ia dapat menurunkan multiplisitas dalam dirinya sendiri ${ }^{12}$ sehingga ia menjadi sebab bagi yang lain. Ketika akal pertama ini berpikir wujud yang di atasnya (wujud pertama), maka timbullah wujud akal kedua. Dengan cara yang sama seperti di atas maka akal-akal itu mengadakan multiplisitas sampai akal kesepuluh atau al-'Aql al-Fa'al (العقل الفعال / Akal Aktif). ${ }^{13}$

Kepastian sistem emanasi yang melimpah sebagai suatu keharusan, dan kemungkinan sebab penyerapan adalah ketergantungan total wujud mungkin kepada Wajib al-Wujud, sebagai sebab-sebab pengetahuan. Akal pertama sebagai hirarki tertinggi dalam wujud kosmik hanya mempunyai suatu kemampuan dan kekuatan, yaitu pengetahuan yang diterima dari sebab pertama. Kekuatannya yang bersifat cahaya Ilahi ini dapat menyerap makna-makna yang tidak dimengerti oleh indera dan nalar. ${ }^{14}$ Pengetahuan yang diterimanya itu sebagai prototype dari ma'rifat (المعرفة / mengenal Allah). ${ }^{15}$ Oleh karena itu ia penuh dengan pengetahuan dan kekuatan, dan meguasai seni dan sains. ${ }^{16}$ Tentang Wajib al-Wujud, esensi dirinya sendiri sebagai Wajib al-Wujud karena karunia pihak lain, dan dirinya

\footnotetext{
${ }^{11}$ Hossein Filsafat Illuminasi.... , 139.

12 Ibid., 203.

13 M.M. Syarif, Para Filosof Muslim (Bandung: Mizan, 19930), 70-71; Harun Nasution, Filsaafat dan Mistisisme dalam Islam (Jakarta: Bulan Bintang, 1991), 27-30; A. Hanafi, Pengantar Filsafat Islam (Jakarta: Bulan Bintang, 1990), 9394.

${ }^{14} \mathrm{Abu}$ Hamid Muhammad bin Muhammad al-Ghazali, Misykah al-Anwar.....,1827.

15 Ibid., 204.

${ }^{16}$ Abu Hamid Muhammad bin Muhammad al-Ghazali, Kimiya al Sa'adah (Kairo: Dar al-Fahm, 1964), 14.
} 
Abd. Kadir

sendiri sebagai wujud kontingensi, merupakan pengetahuan yang melekat pada dirinya. ${ }^{17}$

\section{Akal Aktif}

Diantara rentetan emanasi terdapat al-'Aql al-Fa'al ( العقل العقل (الفعال Active Intellect atau Akal Aktif), atau al-'aql al-'asyir العاشر/akal kesepuluh). Akal Aktif merupakan istilah lain untuk ruh suci atau malaikat Jibril, $^{18}$ dan sebagai substansi kemalaikatan $^{19}$ yang berupa cahaya. Di dalam wujud emanatif kesepuluh ini terdapat segala bentuk ${ }^{20}$ yang ada sejak azali (الازلى tanpa permulaan). ${ }^{21}$ Selain itu, ia sebagai sumber eksistensi jiwa, ${ }^{22}$ sumber hukum dan undang-undang bagi kehidupan moral dan sosial. ${ }^{23}$ Pengetahuan intuitif disampaikan melalui akal ini; dan yang tertinggi berupa wahyu dan ilham. $^{24}$ Dengan demikian wahyu dan ilham adalah

17 Hosen Nasr, An Introduction...., 204.

18 Ibid., 268.

19 Muhammad Yasir Nasution, Manusia Menurut al Ghazali (Jakarta: Raja Grafindo Persada, 1996), 101.

20 Bentuk (al-shurah atau form) adalah struktur yang dapat dimengerti; ciri-ciri yang membentuk substansi yang dibedakan dengan materi di dalam mana ciriciri tersebut termuat, hakikat, sebab bentuk. Ali Mudhofir, Kamus......, 65. Dalam pandangan Sa'id Syaikh bahwa bentuk adalah esensi suatu benda yang menyatu dengan materi pertama (hayula membentuk benda tertentu dan sebenarnya merupakan prinsip yang menentukan materi pertama yang secara aktual menjadi benda semacam itu, tetapi tanpa materi atau bentuk tidak akan ada benda konkrit sama sekali. Sa'id Syaikh, Kamus Filsafat Islam, Penterj.: Machnun Husein (Jakarta: Rajawali, 1991), 85-86.

${ }^{21}$ Harun Nasution, Filsaafat...., 31.

22 Amin Abdullah, The Idea of Universality of Ethical Norm in Kant and Ghazali, (Ankara: Kutlu Dogu'a, 1993), 193.

23 Ibid., 90.

24 Hasan Langgulung, Asas-Asas Pendidikan Islam (Jakarta: Pustaka al-Husna, 1992), 282. 
pancaran emanatif dari Tuhan melalui Akal Aktif. ${ }^{25}$ Hubungan akal ini dengan seseorang sama dengan hubungan antara matahari dan mata. ${ }^{26}$

Ibnu Sina menisbatkan semua operasi intelektual kepada-Nya, dan membebaskan dari inisial apapun terhadap pikiran. Pikiran hanyalah melakukan persiapan diri -dengan melalui kondisi-kondisi kekuatan persepsi dan pemahamanuntuk menerima derajat yang sepadan bagi dirinya dengan intensitas cahaya yang lebih besar didapat dari spirit yang paling dekat dari sumbernya. ${ }^{27}$ Kekuatan akal ini tidak terkait dengan materi, karena ia sebagai causa (penyebab) terpisah dari materi, terutama ketika melakukan kegiatan intelektual, demikian menurut Ibn Rusyd. ${ }^{28}$

Wujud emanatif ini yang menerima pengetahuan langsung dari Tuhan dengan hanya menangkap arti-arti terlepas dari materi, sebagai akibat bentuk murni tanpa materi berada padanya. Akal Aktif mengandung berbagai prinsip gambar-gambar rasional yang bersifat abstrak, dan menjadi sumber pengetahuan akal. Pengetahuan seseorang secara spiritual dicapai dengan penyatuan eksistensial dengan Akal Aktif, $^{29}$ yang mempunyai potensi dan fungsi menghubungkan antara hamba dengan Tuhannya. ${ }^{30}$ Dalam tindak operasional akal yang penuh dengan keajaiban-keajaiban ini memancarkan pengetahuan yang berupa bentuk itu kepada seseorang dalam kenyataan tanpa bimbang dan ragu. ${ }^{31}$ Kemungkinan ini bisa

\footnotetext{
25 Ibrahim Madkur, Fi Falsafah al-Islamiyah ( Mesir: Dar al-Ma'arif, [tt]), 97.

${ }^{26}$ Harun Nasution, Filsafat ....., 31.

27 Mehdi Ha'iri Yazdi, Ilmu Hudhuri....., 36.

28 Ibid, 47.

${ }^{29}$ Mehdi Ha'iri Yazdi, Ilmu Hudhuri....., 43.

${ }^{30}$ Muhammad 'Utsman Najati, Jiwa dalam Pandangan Filosof Muslim, Penterj. : Gazi Saloom (Bandung: Pustaka Hidayah, 2002), 228.

31 Hosen Nasr, An Introduction....., 20.
} 
dicapai, karena ada kecenderungan jiwa manusia suci berhubungan dengan akal ini. ${ }^{32}$ Selanjutnya ia dapat mengadakan hubungan dengan Tuhan, sehingga mendapatkan wahyu atau ilham melalui Akal Aktif. ${ }^{33}$ Maka hubungan seseorang dengan Tuhan ditandai dengan pencerahan, yaitu pencerahan yang tidaklah keluar dari-Nya secara langsung, tetapi dengan perantaraan akal ini. ${ }^{34}$ Melalui akal ini -sebagai pengatur semua yang berada di muka bumi- ${ }^{35}$ siapapun yang dapat berhubungan dan berkomunikasi dengan akal ini, iapun mengenal atau mengetahui hakikat-hakikat tertentu. ${ }^{36}$

\section{E. Fisik Manusia}

Manusia terdiri dari unsur jasmani (biologis) dan ruhani (spiritual); dan setiap unsur mempunyai tuntutan dan kebutuhannya sendiri. Secara biologis ia terdiri dari unsur mineral, tumbuh-tumbuhan, dan hewan, serta secara spiritual ia mempunyai potensi kemalaikatan, karena sejak kejadiannya telah ditiupkan ruh ke dalamnya, sehingga tingkatannya lebih tinggi dari sekedar makhluk yang hanya mempunyai aspek biologis. Jasadnya yang dibangun dari tanah dapat berhubungan dengan dunia material dan aspek spiritualnya dapat berhubungan dengan Tuhan.

Asumsi dasar tentang manusia pada umumnya, bahwa ia tidak mempunyai kemampuan mengetahui segala yang dibutuhkan bagi kelangsungan dan kesempurnaan hidupnya sesuai dengan tuntutan hakikatnya. Tetapi dalam dirinya

\footnotetext{
32 Ibrahim Madkur, Fi Falsafah al-Islamiyah ....., 60.

33 Ibid., 90.

34 Ibid., 51.

35 Ahmad Fuad al-Ahwani, Filsafat Islam, Suntingan: Sutardji Calzoum (Jakarta: Pustaka Firdaus, 1995), 146.

36 Harun Nasution, Filsafat ......, 31. 
terdapat sekumpulan potensi yang sangat diperlukan dan turut membangun kepribadiannya. Potensi yang kompleks itu terdiri dari berbagai macam daya yang dapat menempatkannya pada posisi antara sifat ketuhanan dan sifat kehewanan. ${ }^{37}$ Unsur kehewanannya terdapat dalam aspek fisik, dan unsur ketuhanan terdapat dalam dirinya yang ada sejak diciptakan dalam alam ruh, ${ }^{38}$ maka ia mempunyai kemampuan untuk berada dalam berbagai dataran yang berbeda, mulai yang terendah sampai tertinggi. ${ }^{39}$

Manusia adalah potensi citra yang meliputi segala jenis apa saja yang ada dalam alam ini; seakan-akan ia adalah segalagalanya yang berada dalam alam; ${ }^{40}$ atau sebagai mikrokosmos yang mempunyai semua derajat eksistensi dalam dirinya, dan mempuyai akal sebagai prinsip batiniyah dari wujudnya. ${ }^{41}$

Indera sebagai bagian dari aspek biologisnya, bagaikan jendela yang terbuka menghadap ke dunia luar, sehingga dapat melakukan pemgamatan dan menerima kesan-kesan. Ia juga mempunyai daya nalar yang memungkinkan ia berpikir. Oleh karena itu ia berada di antara dunia penginderaan dan penalaran. Tetapi yang lebih ajaib dari itu, ruhnya memiliki jendela yang terbuka ke alam spiritual yang tidak kasat mata, ${ }^{42}$ dan tidak bisa dipersepsikan dengan penalaran. Ketika aspek fisik dan nalar terbatas kemampuannya, maka instrumen ruhani berperan untuk mencapai sesuatu yang supra rasional dan supra natural. Dengan bantuan Akal Aktif ia dapat

\footnotetext{
37 Ahmad Fuad al-Ahwani, Filsafat Islam ....., 101.

${ }^{38}$ Hasan Langgulung, Asas-Asas Pendidikan....., 294.

${ }^{39}$ Abu Hamid Muhammad bin Muhammad al-Ghazali, Kimiya al Sa'adah ......, 61.

40 Abu Hamid Muhammad bin Muhammad al-Ghazali, Misykah al-Anwar ......, 70.

${ }^{41}$ Hosen Nasr, An Introduction ....., 41 dan 259.

42 Abu Hamid Muhammad bin Muhammad al-Ghazali, Kimiya' al- Sa'adah 14.
} 
mengarahkan pandangannya ke realitas malaikat dan akal murni. $^{43}$

Keberadaaan fisik dan anggotanya dalam hubungannya dengan aspek spiritual hanya sebagai kendaraannya. Badan tetap diperlukan bagi aspek spiritual walaupun hanya bersifat instrumental. ${ }^{44}$ Aspek ruhani sebagai esensi manusia ${ }^{45}$ adalah aspek terdalam kepribadiannya, dan mempunyai peran yang sangat penting. Penglihatan ruhani tidak terbatas pada limitasi material, karena dilihat oleh sesuatu yang eksistensinya tidak tergantung pada tubuh. ${ }^{46}$

\section{F. Jiwa Manusia}

Jiwa terpisah dari tubuh, karena ia bersifat tetap sedangkan tubuh berubah, maka ia lebih utama daripada tubuh; ${ }^{47}$ baik ketika berhubungan dengan tubuh atau tidak. Ia merupakan substansi yang dapat mengenali hal-hal yang rasional dan makna yang universal. ${ }^{48}$ Esensi jiwa suci dapat menangkap sesuatu yang dapat dinalar secara potensial mandiri, karena ia mempunyai kesadaran diri. Jiwa meliputi beberapa substansi, dari akal yang paling atas sampai potensi dan kemampuan seseorang yang paling rendah seperti sifat nabatiyah-nya. $^{49}$

Jiwa mempunyai dorongan nafsu nabatiyah sampai al'Aql al-Mustafad. Dengan nafsu nabatiyah-nya seseorang dapat berhubungan dengan alam duniawi. Dengan nafsu binatangnya

\footnotetext{
${ }^{43}$ Hosen Nasr, An Introduction ....., 258.

44 Muhammad Nasution, , Manusia ......, 190.

${ }^{45}$ Hossein Ziai, Filsafat Illuminasi...., 139.

${ }^{46}$ A.E. 'Afifi, Filsafat Mistis Ibnu 'Arabi, penterj.: Sjahrir Mawi dan Nandi Rahman (Jakarta: Gaya Media Pratama, 1995), 161.

47 Ibrahim Madkur, Fi Falsafah al-Islamiyah ....., 235.

48 Ibid., 229.

${ }^{49}$ Hosen Nasr, An Introduction ....., 202. 
ia dapat melakukan gerakan dan tindak mengetahui, dan dengan akalnya ia mempunyai potensi untuk berpikir sesuatu dari yang konkrit sampai yang abstrak. Ketika jiwa mengenali dan meliput sesuatu, ia merupakan substansi ruhani. ${ }^{50}$ Oleh karena itu jiwa mempunyai penginderaan alam rabbany yang penuh dengan bentuk segala sesuatu dan dunia materi. ${ }^{51}$

Human soul (النفس الناطقة/ jiwa manusia) yang diberikan kepada setiap wujud manusia oleh Akal Aktif sebagai tambahan untuk kesempurnaan jiwa vegetatif (tumbuh-tumbuhan) dan animal (hewani), sehingga ia mempunyai tindakan yang berada di antara dunia bentuk dan dunia materi. Untuk memikirkan sesuatu manusia mempunyai akal yang dapat mencapai alam kemalaikatan melalui bantuan Akal Aktif. ${ }^{52}$ Akibat peran Akal Aktif menyebabkan pikiran mengadakan transformasi dari Akal Material (potensial) -sebagai tingkatan akal yang paling rendah- menuju ke Akal Habitual -suatu tingkatan akal yang berada di atasnya- atau mencapai tingkatan yang lebih tinggi lagi, yaitu Akal Aktual dan Akal Mustafad. ${ }^{53}$

Ketika Akal Aktif berhubungan dengan jiwa seseorang, jiwa itu mendapat pancaran cahayanya maka ia menjadi al-'Aql al-Mustafad karena Akal Aktif sebagai wahib al-shuwar (الواهب الصور/ pemberi bentuk), sehingga fungsi jiwa itu dapat menangkap arti-arti dan bentuk-bentuk. Jika ia telah melepaskan diri dari kendala fisik, ia akan mengalami cahaya penyingkapan (الانوار السا نحة), kemudia ia disebut dengan jiwa abstrak, karena ia telah memperoleh cahaya Tuhan. Jiwa yang bersih jernih mendapat faydl ( الفيض/ limpahan) cahaya secara

50 Ibrahim Madkur, Fi Falsafah al-Islamiyah....., 231.

${ }^{51}$ Hosen Nasr, An Introduction ....., 269.

52 Ibid.. 258.

53 Ibrahim Madkur, Fi Falsafah al-Islamiyah ......, 51-52. 
terus-menerus dan bersambung-sambung dari cahaya Tuhan. Maka kesempurnaannya terletak pada geraknya menuju padaNya, ${ }^{54}$ mencintai-Nya dan dekat pada-Nya. ${ }^{55}$

Akal dalam merambah jalan peningkatan dan perkembangannya melalui fase-fase yang satu sama lain saling menopang karena pada awalnya ia merupakan akal potensial, tetapi jika ia telah mempersepsi sebagian besar pengetahuan yang umum dan realitas-realitas yang universal, maka ia akan menjadi Akal Aktual. Batas pandangannya melampaui pandangan universal, maka ia meningkat menuju tahapan tertinggi yang bisa dicapai, yaitu derajat Akal Mustafad (Acquired Intelect/ Akal Limpahan) atau derajat emanasi dan inspirasi. $^{56}$ Oleh karena itu kesempurnaan akal apabila mencapai derajat mustafad, dan pada derajat itulah kesempurnaan manusia terwujud. ${ }^{57}$ Apabila akal menjadi Akal Mustafad, ia berhak menerima cahaya Ilahi dengan segera berhubungan langsung dengan Akal Aktif.

\section{G. Perolehan Pengalaman dan Pegetahuan dari Sumbernya Secara Emanatif (Pancaran)}

Persepsi inderawi dan nalar sebagai langkah pertama dalam membuka dan menyiapkan akal untuk pengetahuan rasional. Pada dasarnya pengetahuan rasional tidak diperoleh melalui jalur inderawi, tetapi melalui jalur luar akal, atau ilham dan emanasi dari Akal Aktif, yaitu akal yang terpisah dari materi. ${ }^{58}$ Interaksi keduanya memungkinkan terjadinya intuisi

\footnotetext{
54 Ibrahim Madkur, Fi Falsafah al-Islamiyah ...., 80.

55 Muhammad Yasir Nasution, Manusia......, 124.

56 H.M. Amin Syukur dan Masyharudin, Intelektualisame Tasawuf (Semarang: Lembkota, 2002), 93.

${ }^{57}$ Muhammad 'Utsman Najati, Jiwa ....., 168.

58 Ibid., 171-228
} 
yang tumbuh pada diri manusia tanpa didahului keterangan logis dan tidak bergantung pada pengamatan inderawi, ${ }^{59}$ sehingga tidak terbatas pada persepsi inderawi yang nisbi, tetapi dapat meningkat pada serapan-serapan pengetahuan yang bersifat mutlak.

Jika akal menelaah gambar-gambar inderawi yang ada dalam konsepsi, dan Akal Aktif melakukan hubungan dengannya, maka ia siap untuk menangkap makna-makna umum dalam perspektif Akal Aktif. Sebagaimana juga hubungan pengetahuan empirik dan rasional dengan pengetahuan intuitif sebagai produk akal dalam level yang berbeda dapat dilihat bahwa akal sebagai sarana yang berfungsi untuk memperoleh pengetahuan yang benar. ${ }^{60}$ Disamping itu akal sebagai suatu model emanasi diciptakan untuk mencapai tingkat realisasi diri secara mutlak. Namun karena realisasi akal terikat pada prinsip-prinsip hirarkhi emanasi, dan secara mutlak terserap ke dalam Wajib al-Wujud, maka proses realisasi diri itu lebih menyerupai semacam identifikasi proposisi (keruntutan) hubungan dengan Dzat Yang Maha Esa. ${ }^{61}$

Akal pada hakikatnya substansi ruhaniyah yang menjadikan seseorang dapat memahami hakikat kebenaran ruhaniyah. Menurut Plato, akal mempunyai kemampuan penampakan terhadap objek transenden, sehingga bentukbentuk objek yang terfahami dari pengetahuan transenden memiliki eksistensi yang nyata dan merupakan wujud dalam dirinya sendiri dan tidak bergantung pada proses pemikiran maupun objek fisik tersendiri yang berada dalam dunia

${ }^{59}$ H.M. Amin Syukur, Tasawuf Sosial (Yogyakarta : Pustaka Pelajar, 2004), 2627; dan H.M. Amin Syukur dan Masyharudin, Intelektualisame...., 87.

${ }^{60}$ Al-Ghazali, Abu Hamid Muhammad bin Muhammad, Ihya' 'Ulum al-Din, Juz III ....., 42 dan 82.

61 H.M. Amin Syukur dan Masyharudin, Intelektualisame....., 99. 
menjadi. ${ }^{62}$ Dengan demikian dunia transenden dapat difahami oleh akal. Sedangkan bagi Aristoteles pengetahuan akal adalah abstraksi bentuk-bentuk objek spasio temporal. ${ }^{63}$ Pengetahuan akal menurut Ibn Sina maupun al-Farabi diperoleh berdasarkan emanasi diri dan unifikasi dengan intensitas yang terpisah, yaitu ide atau bentuk-bentuk Ilahi. ${ }^{64}$

Akal merupakan aktivitas seseorang paling mulia dan merupakan bagian dari akal Ilahi, dan memiliki peran yang penting dalam menjawab segala persoalan. ${ }^{65}$ Kekuatan akal seringkali disebut pula dengan cahaya Ilahi, karena mendapat bimbingan cahaya iman ${ }^{66}$ - dapat menyerap makna-makna yang tidak dapat dicapai oleh indera. ${ }^{67}$ Hal-hal rasional yang ada pada Akal Aktual segera tergambar dalam Akal Mustafad tanpa susah payah. Akal Mustafad mempunyai potensi dan fungsi penampakan terhadap objek transenden, menyingkap arti dan bentuk tanpa materi. Jika hal-hal rasional sampai kepadanya, maka ia adalah cahaya yang mendapat cahaya Akal Mustafad, ${ }^{68}$ sehingga mampu menerima emanasi dan ilham dari Akal Aktif yang terpisah dari jiwa. ${ }^{69}$ Kesempurnaan akal apabila mencapai derajat mustafad dan pada derajat itulah kesempurnaan manusia terwujud. Ia adalah derajat kesempurnaan yang tertinggi tetapi berbeda dengan Akal Aktif. Ketika seseorang berada pada derajat kesempurnaan intelektual -sebagai

\footnotetext{
62 Mehdi Ha'iri Yazdi, Ilmu Hudhuri....., 23.

63 Muhammad Yasir Nasution, Manusia....., 25-26.

${ }^{64}$ Mehdi Ha'iri Yazdi, Ilmu Hudhuri....., 39.

65 Karen Amstrong, Sejarah Tuhan, penterj.: Zainul Am (Bandung: Mizan, 2002), 249.

66 Muhammad 'Abdullah al-Syarqawi, Sufisme dan Akal, penterj.: Halid al-Kaf (Bandung: Pustaka Hidayah, 2003), 179 dan 228.

$67 \mathrm{Abu}$ Hamid Muhammad bin Muhammad al-Ghazali, Cinta dan Bahagia, penterjemah: Abdullah bin Nuh (Jakarta : Tinta Mas, 1992), 8.

68 Ibid, 223.

${ }^{69}$ Muhammad 'Abdullah al-Syarqawi, Sufisme....., 117.
} 
realisasi diri yang sempurna- maka semua potensialitasnya menjadi aktual yang menyebabkan tidak adanya potensi dan tindakan, karena hubungan aksi dan potensi ini telah berakhir. Ketiadaan aksi ini mengakibatkan tidak adanya aksi immanen dalam pikirannya atau ia berada dalam pengetahuan yang sempurna.

Kesempuraan akal memungkinkan ia menerima pengetahuan dan pengalaman secara langsung tanpa perantaraan indera maupun nalar, yaitu pengatahuan yang bebas dari simbolisme apapun dan hal ini kadang-kadang disebut dengan pengetahuan intuitif. Pengetahuan intuitif mengatasi sifat lahiriyah pengetahuan simbolis yang pada dasarnya bersifat analisis, tetapi ia memberikan pengetahuan tentang objek secara keseluruhan yang mutlak tanpa suatu ungkapan. Pengetahuan analisis atau pengetahuan yang diperoleh melalui jalan pelukisan tidak akan dapat menggantikan hasil pengenalan secara langsung dari pengetahuan intuitif. ${ }^{70}$ Pengetahuan intuitif sejenis pengetahuan yang dikaruniakan Tuhan kepada seseorang dan dipatrikan pada kalbunya sehingga tersingkap olehnya segala rahasia dan tampak olehnya sebagian realitas.

Pengetahuan dan pengalaman yang dicapai dengan cara demikian sebagai pengetahuan pemberiaan. Kondisi ini menyebabkan ia memperoleh kemampuan untuk menerima pencerahan Akal Aktif dalam segala hal, karena Akal Aktif mengandung berbagai prinsip gambar-gambar rasional yang bersifat abstrak. Bentuk-bentuk akali yang tersimpan dalam Akal Aktif akan beremanasi pada jiwa, kemudian pengetahuan itu difahami dan diterima dengan mudah. ${ }^{71}$ Intuisi sebagai

70 Louis 0 Kattsoff, Pengantar Filsafat, penterj.: Soejono Soemargono (Yogyakarta: Tiara Wacana, 1992), 146.

${ }^{71}$ H.M. Amin Syukur dan Masyharudin, Intelektualisame ...., 101. 
naluri yang menjadi kesadaran diri dapat menuntun pada kehidupan immateri. Seseorang yang memperolehnya, memungkinkan untuk mendapatkan pengetahuan langsung yang mengatasi pengetahuan yang diperoleh lewat indera dan akal. $^{72}$ Karena ia sebagai sarana untuk mengetahui secara langsung dan seketika. ${ }^{73}$ Bahkan jika intuisi dapat meluas dan mendominasi kehidupan manusia ia dapat memberi petunjuk vital, yaitu dorongan ruhani dari dalam dan langsung. Intuisi yang baik adalah yang dialami oleh orang-orang yang sudah lama berkecimpung dalam bidang tertentu.

Agar pengetahuan intuitif dapat diterima, maka harus disandarkan kepada moralitas subjek, ${ }^{74}$ akal sehat, dan keahlian subjek. Sebagai pengetahuan yang wataknya berbeda dan lebih tinggi dari pengetahuan indera dan akal, maka ia sama dengan cahaya kenabian atau pengalaman ma'rifah, ${ }^{75}$ yaitu pengetahuan dengan pengenalan langsung, yang secara eksklusif masuk dalam jiwa atau hati. ${ }^{76}$ Pengenalan ma'rifah melalui al-qalb, tanpa belajar melainkan lewat kasyf dan ilham. Karena ia didapatkan dalam alam rabbaniyah (الربانية) ketuhanan). Pengetahuan rabbaniyah mengaitkan manusia dengan alam ghaib, dan hasilnya disebut dengan berbagai macam term diantaranya: 'ilm al-asrar (العلم) الاسرار, 'ilm ladunni (العلم لدن), ma'rifah (الالمام), ilham dan lain sebagainya. Prosesnya tiada diketahui bagaimana dan dimana diperolehnya. Ilham adalah peringatan Allah kepada jiwa jika ia telah mencapai kadar kejernihan dan kekuatan isti'anah (الاستعانة/

\footnotetext{
72 Ibid, 70-72.

${ }^{73}$ Louis O. Kattsoff, Pengantar ....., 146.

74 Ibid., 124.

75 Al-Ghazali, Abu Hamid Muhammad bin Muhammad, Ihya' 'Ulum al-Din, Juz III ....., 3 .

${ }^{76}$ H.M. Amin Syukur dan Masyharudin, Intelektualisame....., 73.
} 
pertolongan) tertentu, sehingga ia mampu memperoleh pengetahuan tanpa perantara antara dirinya dengan Allah SWT.

Pengetahuan rabbaniyah atau ladunniyah adalah tingkatan tertinggi pengetahuan yang dicapai melalui berbagai mujahadah dan riyadlah. Dengan demikian komposisi manusia paling sempurna mempunyai tiga unsur, yaitu: ruh dengan kecakapan aqliyah-nya, jiwa dengan sifat hawa nafsunya, dan badan dengan sifat penginderaaanya. Ketiga dapat bekerja saling inklusif secara sinergis untuk membangun satu kesatuan menuju terwujudnya manusia yang semua potensilitasnya berekembang memenuhi kodrat hidupnya.

\section{H. Emanasi Pengetahuan dan Pengalaman dari Akal Aktual ke Akal Mustafad}

Akal Mustafad merupakan suatu subtansi untuk melihat alam supra natural dan supra rasional, walaupun dengannya ia tidak sampai mencapai level kenabian, yaitu tingkat lebih tinggi yang menyebabkan seseorang dapat melihat alam ghaib berserta rahasia-rahasianya. ${ }^{77}$ Daya seseorang untuk mencapai pengetahuan tertinggi (pengetahuan tentang Tuhan) dan pengetahuan tentang hakikat yang lainnya melalui akal ini, karena ia dapat berhubungan langsung dengan Akal Aktif. Akal ini bagian dari jiwa atau beberapa potensi jiwa atau segala sesuatu yang dzatnya dipersiapkan (untuk menangkap pengetahuan). ${ }^{78}$ Kemampuannya dapat menangkap pure form (bentuk murni), yaitu arti-arti terlepas dari materi (abstracted intelegible).

\footnotetext{
77 Abu Hamid Muhammad bin Muhammad al-Ghazali, al- Munqidz min a-Dlalal (Beirut: al-Sab'iyah, tt), 49.

${ }^{78}$ Muhammad 'Abdullah al-Syarqawi, Sufisme ......, 116.
} 
Apabila sesuatu yang mawjud dan forma-nya terlepas tanpa materinya berarti keseluruhannya menjadi forma bagi segala yang mawjud itu, sehingga ia menyadari pengetahuan itu secara aktual, dan menyadari kesadarannya secara faktual. Akal ini bersifat pasif dan hanya mampu menerima pengetahuan dari Akal Aktif. Pengetahuannya yang bersifat perolehan dari akal yang selamanya aktual itu dan dengan sebab itu ia menjadi aktual. Pengetahuan perolehan ini bersifat hakiki dan hanya dapat diperoleh dengan syarat melepaskan diri dari ketergantungan terhadap duniawi, dan berfikir secara kontemplatif tentang wujud, ${ }^{79}$ sehingga wujud ruhaniyahnya menarik ke atas untuk merubah seseorang ke arah tingkat malaikat, dan beroperasi dalam alam supra duniawi, yaitu di luar batas ruang dan waktu. $^{80}$ Ia dapat memandang sesuatu sebagaimana adanya, dengan syarat harus kosong dari wahm (هo/imajinasi). Bila kesadaran seseorang tidak lagi diperantarai pikiran apapun, maka dapat dibangun komunikasi intelektual dengan objek terfahami yang pada puncaknya adalah pemahaman terhadap Akal Aktif. ${ }^{81}$ Dengan demikian bahwa di balik akal ada kondisi lain yang dapat menyerap keajaiban yang tak terjangkau oleh akal dan indera. ${ }^{82}$

Sebagai ciptaan yang berasal dari pemikiran Tuhan, seseorang menjadi terintegrasi dalam archetype suci ${ }^{83}$ dalam tindakan inteleksi. ${ }^{84}$ Jika alam secara global timbul dari pancaran emanasi, maka aspek ruhani bisa mencapai keindahan-Nya dengan perantaraan emanasi dan pancaran. ${ }^{85}$

\footnotetext{
${ }^{79}$ Harun Nasution, Filsafat ......, 117-181.

${ }^{80}$ Hasan Langgulung, Asas-Asas Pendidikan......, 28-29 dan 76.

${ }^{81}$ Mehdi Ha'iri Yazdi, Ilmu Hudhuri....., 43.

82 Abu Hamid Muhammad bin Muhammad al-Ghazali, Misykah al-Anwar ......, 83.

83 Kecenderungan pokok untuk mewujudkan diri, Ali Mudhofir, Kamus ....., 15.

${ }^{84}$ Hosen Nasr, An Introduction ....., 259.

85 Ibrahim Madkur, Fi Falsafah al-Islamiyah....., 60.
} 
Jika seseorang dapat berhubungan dengannya, ia dapat mempersepsi berbagai macam pengetahuan, karena ruhnya dapat berhubungan dengan jiwa samawi yang akan menolongnya menyingkap kebaikan. ${ }^{86}$ Akal Aktif memberikan kecerdasan yang diperoleh melalui iluminasi kepada akal sehingga menyebabkan daya jiwa berfungsi secara penuh dan dapat menerima ide-ide yang datang dari al-ma'qul (المعقول) sesuatu yang rasional) dan spiritual.

Dalam wacana sufistis, pengetahuan itu diperoleh karena sifat dan substansi ruh merupakan pancaran cahaya Tuhan, maka ia dapat menangkap ilmu-ilmu yang ada pada Tuhan. Al-ruh dapat menangkap, mencerap pengetahuan dari level yang tertinggi -pengetahuan yang diperoleh tanpa daya upaya terhadap objek non fisik- sampai terendah yang dicapai melalui usaha belajar terhadap objek fisik dan rasional. Seperti al-Ghazali dan al-Farabi mempercayai adanya pengetahuan batin di balik realitas fisik.

Pengalaman manusia secara empirik didapat dari pengalaman inderawi sedangkan pengetahuaan rasional dikonsep oleh nalar melalui premis-premis yang dapat dipikirkan secara logis. Melalui nalar seseorang bergerak dari yang telah diketahui ke arah yang tidak diketahui dan mendapatkan pengetahuan melalui penyelidikan dan penemuan. ${ }^{87}$ Pengalaman lainnya yang bersifat ruhani dicapai melalui emanasi dari akal Aktif ke Akal Mustafad ketika terdapat hubungan secara intim antara keduanya. Emanasi (الفيض) adalah sesuatu yang dengannya sebuah eksistensi dilahirkan dari yang lain, dan bergantung pada eksistensi lain tanpa perantaraan materi, instrumen, ataupun waktu.

86 Ibid., 60-61.

87 Ali Ashraf, Horison Baru Pendidikan Islam, penterj.: Sori Siregar (Jakarta: Pustaka Firdaus, 1989), 27. 


\section{Kesimpulan}

Kepastian sistem emanasi sebagai suatu keharusan sumber emanasi dan sebagai kemungkinan bagi wujud emanatifnya, karena adanya penyerapan dan kebergantungan secara total wujud yang mungkin kepada sumber emanasinya. Hirarki emanasi itu menyiratkan kontinuitas dan kontingensi total model emanatif yang lebih rendah pada prinsip-prinsip terdekatnya, baik yang berada dalam tingkat pertama maupun terakhir. Wujud emanatif tidak pernah dilepaskan dari sumbernya dengan berdiri sendiri sebagai entitas yang mandiri. Wujud emanatif tetap eksis dalam ketergantungannya pada sumbernya. Ketergantungan murni terhadap yang lain, karena ia tidak mempunyai realitas dalam dirinya selain sebagai subordinat dari suatu realitas. Proses emanasi tidak menyerah pada kehampaan total, tetapi ada keterkaitan tak terputus antara berbagai level wujud emanatif dengan prinsip terdekatnya. Dengan demikian sumber terdekatnya memberikan pencerahan kepada suatu wujud emantif.

\section{DAFTAR PUSTAKA}

Abu Hamid Muhammad bin Muhammad al-Ghazali, Kimiya al Sa'adah (Kairo: Dar al-Fahm, 1964). , Misykah al-Anwar (Kairo: Dar al-Fahm, 1964). , Ihya' 'Ulum al-Din, Juz III. , Al-Munqidz min al-Dhlalal (Beirut: al-Sab'iyah, $\mathrm{tt}$ ). - Cinta dan Bahagia, penterjemah: Abdullah bin Nuh (Jakarta : Tinta Mas, 1992).

A.E. 'Afifi, Filsafat Mistis Ibnu 'Arabi, penterj.: Sjahrir Mawi dan Nandi Rahman (Jakarta: Gaya Media Pratama, 1995). 
Ahmad Fuad al-Ahwani, Filsafat Islam, Suntingan: Sutardji Calzoum (Jakarta: Pustaka Firdaus, 1995).

Ali Ashraf, Horison Baru Pendidikan Islam, penterj.: Sori Siregar (Jakarta: Pustaka Firdaus, 1989).

Amin Abdullah, The Idea of Universality of Ethical Norm in Kant and Ghazali, (Ankara: Kutlu Dogu'a, 1993).

Ali Mudhofir, Kamus Istilah Filsafat (Yogyakara : Liberty, 1992).

A. Hanafi, Pengantar Filsafat Islam (Jakarta: Bulan Bintang, 1990).

Hosen Nashr, An Introduction to Islamic Ontological Doctrines (New York: State University, 1993).

Hossein Ziai, Filsafat Illuminasi, penterj.: Afif Muhammad dan Munir (Bandung: Zaman Wacana Mulia, 1988).

Harun Nasution, Filsaafat dan Mistisisme dalam Islam (Jakarta: Bulan Bintang, 1991).

Hasan Langgulung, Asas-Asas Pendidikan Islam (Jakarta: Pustaka al-Husna, 1992).

H.M. Amin Syukur dan Masyharudin, Intelektualisame Tasawuf (Semarang : Lembkota, 2002).

H.M. Amin Syukur, Tasawuf Sosial (Yogyakarta : Pustaka Pelajar, 2004).

Ibrahim Madkur, Fi Falsafah al-Islamiyah ( Mesir: Dar al-Ma'arif, $\mathrm{tt})$.

John Tulltill, The Philosophy of Quthb al-Din al-Sirazi: a Study in Integration of Islamic Philosophy (Boston: Harvard University, 1983).

Karen Amstrong, Sejarah Tuhan, penterj.: Zainul Am (Bandung: Mizan, 2002).

Louis 0 Kattsoff, Pengantar Filsafat, penterj.: Soejono Soemargono (Yogyakarta: Tiara Wacana, 1992).

Muhammad 'Utsman Najati, Jiwa dalam Pandangan Filosof Muslim,

Penterj. : Gazi Saloom (Bandung: Pustaka Hidayah, 2002). 
Abd. Kadir

Muhammad 'Abdullah al-Syarqawi, Sufisme dan Akal, penterj.: Halid al-Kaf (Bandung: Pustaka Hidayah, 2003).

Mir Valiudin,Tasawuf dalam Qur an, penterj: Pustaka Firdaus ( Jakarta: Pustaka Firdaus, 1993).

Mehdi Ha'iri Yazdi, Ilmu Hudhuri, penterj.: Ahsin Muhammad (Bandung: Mizan, 1994).

M.M. Syarif, Para Filosof Muslim (Bandung: Mizan, 19930).

Muhammad Yasir Nasution, Manusia Menurut al Ghazali (Jakarta : Raja Grafindo Persada, 1996).

Sa'id Syaikh, Kamus Filsafat Islam, Penterj. : Machnun Husein, (Jakarta: Rajawali, 1991). 


\title{
KONSERVASI PENDIDIKAN KARAKTER ISLAMI DALAM HIDDEN CURRICULUM SEKOLAH
}

\author{
Fathurrohman \\ (Dosen DPK UIN Sunan Ampel di STAI Taruna Surabaya)
}

\begin{abstract}
Abstrak:
Pendidikan di negeri ini hingga sekarang masih menyisakan banyak persoalan, baik dari segi kurikulum, manajemen, maupun para pelaku dan pengguna pendidikan. SDM Indonesia masih belum mencerminkan cita-cita pendidikan yang diharapkan. Masih banyak ditemukan kasus seperti siswa melakukan kecurangan ketika sedang menghadapi ujian, bersikap malas dan senang bermain, hura-hura, senang tawuran antar sesama siswa, melakukan pergaulan bebas, hingga terlibat narkoba dan tindak kriminal lainnya. Kenyataan membuktikan bahwa Indonesia banyak bermasalah dalam hal karakter. Hal ini berarti bangsa Indonesia yang didominasi oleh umat Islam belum mengamalkan ajaran agama dengan baik. Untuk itu, perlu menjadikan pendidikan karakter Islami sebagai pondasi utama dalam membangun karakter manusia. Dengan agamalah karakter yang seutuhnya bisa dibangun. Namun demikian, untuk zaman sekarang masih diperlukan metode dan strategi yang dikembangkan oleh para ahli moral melalui hidden curriculum di sekolah.
\end{abstract}

Kata Kunci: Pendidikan Karakter dan Hidden Curriculum 


\section{A. Pendahuluan}

Kurikulum merupakan salah satu alat untuk mencapai tujuan pendidikan, dan sekaligus digunakan sebagai pedoman dalam pelaksanaan proses belajar mengajar pada berbagai jenis dan tingkat sekolah. Kurikulum menjadi dasar dan cermin falsafah pandangan hidup suatu bangsa; akan diarahkan kemana dan bagaimana bentuk kehidupan bangsa ini di masa depan, semua itu ditentukan dan digambarkan dalam suatu kurikulum pendidikan. Kurikulum haruslah dinamis dan terus berkembang untuk menyesuaikan berbagai perkembangan yang terjadi pada masyarakat dunia dan haruslah menetapkan hasilnya sesuai dengan yang diharapkan.

Pengertian kurikulum secara luas tidak hanya berupa mata pelajaran atau kegiatan-kegiatan belajar siswa saja tetapi segala hal yang berpengaruh terhadap pembentukan pribadi anak sesuai dengan tujuan pendidikan sehingga akhir-akhir ini muncul salah satu istilah hidden curriculum. Istilah hidden curriculum pertama kali digunakan oleh sosiolog Philip Jackson pada tahun 1968 M. Jackson berpendapat bahwa apa yang diajarkan di sekolah adalah lebih dari jumlah total kurikulum. Dia berpikir sekolah harus dipahami sebagai sebuah proses sosialisasi dimana siswa mengambil pesan melalui pengalaman di sekolah, bukan hanya dari hal-hal yang diajarkan secara eksplisit. Jika ingin mencari hidden curriculum, maka harus melihat apa yang tidak ada pada silabus. ${ }^{1}$

Pendidikan di negeri ini hingga sekarang masih menyisakan banyak persoalan, baik dari segi kurikulum, manajemen, maupun para pelaku dan pengguna pendidikan. SDM Indonesia masih belum mencerminkan cita-cita

\footnotetext{
${ }^{1}$ Michael Apple, "Hidden in Plain Sight, dalam Journal The Formal, Informal, and Hidden Curriculum of a Psychiatry Clerkship, Vol. 84 Nomor 2 (Mey, 2009), 451457.
} 
pendidikan yang diharapkan. Masih banyak ditemukan kasus seperti siswa melakukan kecurangan ketika sedang menghadapi ujian, bersikap malas dan senang bermain, hurahura, senang tawuran antar sesama siswa, melakukan pergaulan bebas, hingga terlibat narkoba dan tindak kriminal lainnya.

Di sisi lain, masih ditemukan pula guru yang melakukan kecurangan-kecurangan dalam sertifikasi dan dalam penyelenggaraan ujian nasional (UN). Atas dasar inilah, pendidikan perlu direkonstruksi ulang agar dapat menghasilkan lulusan yang lebih berkualitas dan siap menghadapi "dunia" masa depan yang penuh dengan problema dan tantangan serta dapat menghasilkan lulusan yang memiliki karakter mulia, yakni: memiliki kepandaian sekaligus kecerdasan, memiliki kreativitas tinggi sekaligus sopan dan santun dalam berkomunikasi, serta memiliki kejujuran dan kedisiplinan sekaligus memiliki tanggung jawab yang tinggi. Dengan kata lain, pendidikan harus mampu mengemban misi pembentukan karakter (character building) sehingga para peserta didik dan para lulusannya dapat berpartisipasi dalam mengisi pembangunan dengan baik dan berhasil tanpa meninggalkan nilai-nilai karakter mulia.

Inilah permasalahan karakter yang melanda sebagian besar bangsa ini. Masih banyak karakter (negatif) lain yang sekarang berkembang bahkan menjadi budaya di tengahtengah masyarakat yang semakin memperparah problem bangsa dan negara. Karena itulah, tahun lalu (2010) presiden kembali mengajak seluruh rakyat Indonesia untuk bersamasama membangun kembali budaya dan karakter luhur bangsa yang sudah memudar. Nilai-nilai karakter mulia yang dimiliki bangsa dan negara Indonesia sejak berabad-abad dan sekarang sudah terkikis harus dibangun kembali terutama melalui pendidikan. Disinilah peran pendidikan karakter dalam hidden 
curriculum sekolah dalam membangun karakter yang islami agar menjadi generasi yang berbudi luhur, berakhlaq mulia yang sesuai dengan tujuan pendidikan.

\section{B. Pendidikan Karakter}

Secara etimologis, kata karakter (Inggris: character) berasal dari bahasa Yunani (Greek), yaitu charassein yang berarti "to engrave" (Ryan and Bohlin, 1999:5). Kata "to engrave" bisa diterjemahkan mengukir, melukis, memahatkan, atau menggoreskan (Echols dan Shadily, 1995:214). Dalam Kamus Bahasa Indonesia kata "karakter" diartikan dengan tabiat, sifat-sifat kejiwaan, akhlak atau budi pekerti yang membedakan seseorang dengan yang lain, dan watak. Karakter juga bisa berarti huruf, angka, ruang, simbul khusus yang dapat dimunculkan pada layar dengan papan ketik (Pusat Bahasa Depdiknas, 2008:682). Orang berkarakter berarti orang yang berkepribadian, berperilaku, bersifat, bertabiat, atau berwatak. $^{2}$

Pendidikan karakter merupakan sesuatu yang baik. Dalam Islam, karakter identik dengan akhlaq, yaitu kecenderungan jiwa untuk bersikap atau bertindak secara otomatis. Akhlaq yang sesuai ajaran Islam disebut dengan akhlaqul karimah atau akhlaq mulia yang dapat diperoleh melalui dua jalan. Pertama, bawaan lahir, sebagai karunia dari Allah. Contohnya adalah akhlaq para Nabi. Kedua, hasil usaha melalui pendidikan dan penggemblengan jiwa. ${ }^{3}$

Dari pengertian di atas dapat dipahami bahwa karakter identik dengan akhlaq, sehingga karakter merupakan nilai-nilai

\footnotetext{
2 Marzuki, Prinsip Dasar Pendidikan Karakter Perspektif Islam, PKn dan Hukum FISE UNY.

3 Erma Pawitasari http://insistnet.com/enamprinsip-pendidikan-karakterislami/
} 
perilaku manusia yang universal yang meliputi seluruh aktivitas manusia, baik dalam rangka berhubungan dengan Tuhan, dengan diri sendiri, dengan sesama manusia, maupun dengan lingkungan, yang terwujud dalam pikiran, sikap, perasaan, perkataan, dan perbuatan berdasarkan normanorma agama, hukum, tata karma, budaya, dan adat istiadat. Dari konsep karakter ini muncul konsep pendidikan karakter (character education). Kehendak merupakan awal terjadinya karakter pada diri seseorang, jika kehendak itu diwujudkan dalam bentuk pembiasaan sikap dan perilaku.

\section{Hidden Curriculum}

Hidden curriculum merupakan "hasil (sampingan) dari pendidikan dalam latar sekolah atau luar sekolah khususnya hasil yang dipelajari tetapi tidak secara tersurat dicantumkan sebagai tujuan".4 Beragam definisi lain telah dikembangkan berdasarkan pada perspektif yang luas untuk mempelajari peristiwa ini. Segala bentuk pendidikan, termasuk aktivitas rekreasional dan sosial, dapat mengajarkan bahan-bahan pelajaran yang sebetulnya tak sengaja karena bukan berhubungan dengan sekolah tetapi dengan pengalaman belajar.

Menurut Syafi'i Ma'arif, hidden curriculum mencakup pengembangan nilai-nilai di sekolah, perhatian, dan penekanan yang diberikan berbeda-beda pula terhadap bidang atau subjek

\footnotetext{
4 Jane Martin, What Should We Do with a Hidden Curriculum When We Find One? dalam The Hidden Curriculum and Moral Education. Ed. Giroux, Henry, dan David Purpel. Berkeley, (California: McCutchan Publishing Corporation, 1983), 122-139.
} 
yang sama, tingkat semangat guru-guru dan kondisi fisik dan iklim sosial sekolah. ${ }^{5}$

Menurut Nasution, kurikulum sebenarnya mencakup pengalaman yang direncanakan tetapi juga yang tidak direncanakan yang disebut dengan "hidden curriculum", seperti: cara anak menjawab, mencontek, sikap terhadap asatidz (guru), disiplin dalam belajar, membina mental diri, dan masih banyak hal lainnya. Dalam hal selanjutnya kurikulum dapat dipandang sebagai ideal / real curriculum, potential / actual, dan juga disebut hidden curriculum. ${ }^{6}$

Diantara macam-macam kurikulum pendidikan adalah kurikulum formal, informal, dan non formal. Kurikulum formal mencakup kegiatan di kelas dan bersifat terencana. Kurikulum non formal terdiri atas aktifitas-aktifitas yang juga direncanakan akan tetapi tidak berkaitan langsung dengan pelajaran akademis dikelas, dan keberadaan kurikulum ini dipandang sebagai pelengkap (suplemen) kurikulum formal. Disamping kurikulum-kurikulum tersebut, terdapat juga hidden curriculum, sebagaimana yang telah disebutkan diatas. Kurikulum ini antara lain berupa aturan-aturan tak tertulis dikalangan siswa.

Dari beberapa pendapat tentang hidden curriculum di atas, dapat diambil suatu pengertian bahwa dalam pelaksanaan pendidikan di sekolah terdapat kurikulum yang tertulis dan kurikulum tak tertulis. Oleh karena itu, seharusnya dua kurikulum tersebut, mendapatkan perhatian bukan hanya kurikulum yang tertulis dan direncanakan saja, agar

${ }^{5}$ Syafii Maarif, "Historiografi dan Pengajaran Sejarah. Makalah (Padang: FPIPS IKIP Padang, 1995), 1.

${ }^{6}$ Nasution, Pengembangan Kurikulum, Cet. IV (Bandung: PT. Citra Aditya Bakti, 1993), 11. 
keberhasilan proses belajar mengajar dan hasil pendidikan sesuai dengan tujuan pendidikan nasional.

\section{Pendidikan Karakter dalam Hidden Curriculum Sekolah}

Mengutip artikel Dyah Kumalasari, Benson Snyder, para pendidik, sosiolog, dan psikolog dalam melukiskan sistem informal dalam dunia pendidikan. Hidden curriculum disebutkan terdiri atas tiga $\mathrm{R}$ yang sangat penting untuk dikembangkan yaitu rules (aturan), regulations (peraturan), dan routines (kontinyu). Dimana setiap sekolah yang menerapkan sistem ini harus beradaptasi. Sosialisasi nilai-nilai moral merupakan suplemen dari tiga $\mathrm{R}$, pelajaran atau mata kuliah tersebut juga akan semakin jelas dan mudah dipahami bila disampaikan dengan jalan klasikal dalam ruang kelas yang teratur. $^{7}$

Rumusan teori Benson Snyder yang dikenal dengan $3 \mathrm{R}$ ersebut sejalan dengan visi dan misi pendidikan, yaitu "beriman dan bertaqwa, berprestasi dan kompetitif, berbudi luhur". Salah satu diantaranya dengan kegiatan pengembangan diri siswa yang bersifat spontan dan keteladanan baik tersurat maupun tersirat yang dirancang dan dikembangkan seperti pembiasaan suasana religius di kawasan lingkungan sekolah.

Berbagai penelitian telah dilakukan pada kajian teori hidden curriculum. Dreeben mengakui hidden curriculum sebagai proses sosialisasi sekolah baik itu meliputi ideologi, keyakinan, nilai dan norma. ${ }^{8}$ Emile Durkheim mengamati bahwa hidden curriculum lebih banyak diajarkan dan dipelajari daripada kurikulum resmi, meskipun tidak secara langsung

7 Jeane H. Balantine, The Sociology of Education A Systematic Analysis (New Jersey: Intence Hall Inc, 1983).

8 Ibid., 83-88. 
disebutkan sebagai "hidden curriculum".9 Program konservasi pendidikan karakter ini harus dilaksanakan oleh semua warga sekolah dengan nilai-nilai agama yang kental bisa dilihat dalam kebiasaan anak-anak bersalaman kepada guru mereka, berperilaku sopan-santun kepada siapa saja bila bertemu, mengambil sampah setiap melihat sampah yang berserakan dan memasukkannya ke dalam bak sampah, dan lain-lain. Bentuk pengendaliannya lewat pantauan baik dilakukan oleh guru, wali kelas, maupun kepala sekolah.

Kajian ini juga mengungkapkan bagaimana cara mengatur program dalam mekanisme kegiatan pendidikan karakter. Hal ini sebaiknya dicantumkan dalam jadwal tersendiri yang diatur oleh kurikulum seperti di bawah ini:

1. Kegiatan pendidikan karakter yang bersifat rutin/ terstruktur dilaksanakan pada waktu pembelajaran efektif dengan mengalokasikan waktu khusus dalam jadwal pelajaran, dibina oleh guru dan konselor sekolah.

2. Kegiatan pendidikan karakter pilihan dilaksanakan di luar jam pembelajaran (ekstrakurikuler) dibina oleh guru, praktisi, atau alumni yang memiliki kualifikasi yang baik berdasarkan surat keputusan kepala sekolah. ${ }^{10}$

Dari pemaparan data di atas, ditemukan bahwa pendidikan karakter Islami ialah pembiasaan suasana religius di kawasan sekolah. yaitu; (1). Budaya S3AS (Salam, Salim, Senyum, Ambil Sampah), (2). Budaya Jum'at Bersih, (3). Halal Bihalal, (4). Peringatan Hari Besar Islam (PHBI), (5). Santunan Kematian, (6). Santunan Anak Yatim, (7). Budaya Anjang Sana

\footnotetext{
9 Fulya Damla Kentli, “Comparison of Hidden Theories”, 83-88.

10 Dokumen perangkat pembelajaran PAI SDN Sawotratap I Gedangan-Sidoarjo tahun pelajaran 2013/2014
} 
keluarga Dewan Guru dan Karyawan, (8) Budaya Tasyakuran, dan (9). Budaya beramal jariyah setiap jum'at. ${ }^{11}$

Adapaun secara terperinci, kegiatan harian, mingguan, tahunan dan insidental dapat diuraikan sebagai berikut:

\section{Kegiatan Harian.}

a. Doa bersama. Kegiatan doa bersama-sama dilakukan setiap hari pada pagi hari tepatnya sebelum pelajaran dimulai, yang dipandu langsung dari radio sekolah dan dipimpin oleh guru yang bertugas secara bergantian.

b. Shalat dhuha. Shalat sunnah dhuha dilakukan oleh para guru dan siswa. Namum pelaksanaannya bukan merupakan kewajiban yang harus dilakukan oleh seluruh anggota masyarakat sekolah karena sifatnya mubah menurut peraturan sekolah. Di sisi lain ada guru yang setiap mau mengajar di pagi hari, guru tersebut sebelum memulai kegiatan belajar mengajar selalu mengajak peserta didik melaksanakan shalat sunnah Dhuha, setelah itu mengajak peserta didik untuk memasuki kelas

c. Pakaian wajib menggunakan busana muslim. Setiap peserta didik putri wajib memakai busana muslim yang intinya menutup aurat sebagai salah satu langkah pembiasaan berpakaian yang baik dan sopan. Sedangkan untuk yang non-muslim tidak ada kewajiban tapi harus menyesuaikan dengan aturan sekolah yakni berpakaian yang baik dan sopan.

d. Silaturrahim antara siswa dengan guru. Kegiatan silaturrahim dilakukan pada pagi hari yaitu sewaktu masyarakat sekolah memasuki lingkungan sekolah. Kegiatan ini dilakukan dengan cara kepala sekolah dan

11 Observasi yang dilakukan oleh penulis di SDN Sawotratap I GedanganSidoarjo pada Bulan Januari-Maret 2014. 
dewan guru berada di lobi sekolah menunggu datangnya peserta didik dan setiap peserta didik yang datang langsung bersalaman dengan para guru sampai bel masuk kelas berbunyi.

e. Pembiasaan salam, sapa, senyum, sopan, dan santun (5S). Pembiasaan ini dilakukan sebagai upaya untuk membiasakan masyarakat sekolah terbiasa dengan mendoakan orang lain dengan mengucapkan salam, ramah dengan menyapa orang di sekitarnya dan senyum sebagai lambang kedermawanan (bersadaqoh), sehingga terciptalah kesopanan dan kesantunan.

\section{Kegiatan Mingguan}

a. Kegiatan ibadah jumat setiap hari jum'at, keputrian pada jum'at siang dan shalat jum'at bagi peserta didik putra. Kegiatan ini sifatnya tidak mengikat.

b. Pengisian kotak amal setiap hari jum'at (infaq dan shadaqoh). Kegiatan ini di laksanakan pada semua kelas yang dikoordinir oleh masing-masing ketua kelas, yang kemudian hasilnya dijadikan satu untuk diberikan kepada fakir miskin dengan melibatkan siswa agar siswa terbiasa dengan sifat dermawan dan menjadi orang yang gemar berinfaq dan shadaqoh.

\section{Kegiatan Tahunan}

a. Peringatan hari besar Islam (PHBI) yang meliputi: peringatan Isro' Mi'raj, Nuzulul Qur'an, dan Maulid Nabi Muhammad SAW. Kegiatan ini dilakukan oleh seluruh warga sekolah pada tiap-tiap Peringatan Hari Besar Islam (PHBI). Ini dilakukan sebagai bentuk hubbud diniyah karena merupakan simbol-simbol agama Islam. 
b. Pelaksanaan sholat tarawih, tadarus, dan pembagian zakat fitra. Pelaksanaan shalat tarawih dilaksanakan secara bergantian mulai dari kelas IV, V, dan VI. Setelah pelaksanaan shalat tarawih diteruskan dengan mengadakan tadarus al-Qur'an. Sedangkan pada minggu terakhir dilakukan pengumpulan dan pembagian zakat fitrah.

c. Shalat Iedul Adha, pembagian daging Qurban. Di SDN Sawotratap I Gedangan-Sidoarjo juga melaksanakan shalat Iedul Adha di sekolah bekerjasama dengan walimurid sebagai bentuk peran serta masyarakat (PSM) dan diteruskan dengan penyembelihan hewan Qurban dan membagi-bagikannya kepada masyarakat.

d. Bakti sosial. Bakti sosial dilakukan ke warga desa yang berada disekitar lembaga SDN Sawotratap I GedanganSidoarjo.

\section{Kegiatan Insidental}

a. Takziyah. Kegiatan takziyah dilaksanakan dengan menyertakan siswa di kelas itu, wali kelas, guru yang mengajar dan juga Paguyupan Kelas selaku pengumpul dana untuk pelaksanaan ta'ziyah.

b. Menjenguk orang sakit. Kegiatan ini dilaksanakan ketika ada peserta didik yang sakit.

Dengan demikian, karakter telah melekat dalam diri peserta didik secara fitriah. Dengan kemampuan fitriah ini, peserta didik mampu membedakan batas kebaikan dan keburukan, dan mampu membedakan mana yang tidak bermanfaat dan mana yang bermanfaat. Harus dipahami bahwa pembawaan fitrah peserta didik ini tidak serta merta menjadikan karakter peserta didik bisa terjaga dan berkembang sesuai dengan fitrah tersebut. Fakta membuktikan 
bahwa pengalaman yang dihadapi masing-masing orang menjadi faktor yang sangat dominan dalam pembentukan dan pengamalan karakternya. Di sinilah pendidikan karakter dalam hidden curriculum mempunyai peran yang penting dan strategis bagi peserta didik dalam rangka melakukan proses internalisasi dan pengamalan nilai-nilai karakter mulia di masyarakat.

\section{E. Kesimpulan}

Kenyataan membuktikan bahwa Indonesia banyak bermasalah dalam hal karakter. Hal ini berarti bangsa Indonesia yang didominasi oleh umat Islam belum mengamalkan ajaran agama dengan baik. Untuk itu, perlu menjadikan pendidikan karakter Islami sebagai pondasi utama dalam membangun karakter manusia. Dengan agamalah karakter yang seutuhnya bisa dibangun. Namun demikian, untuk zaman sekarang masih diperlukan metode dan strategi yang dikembangkan oleh para ahli moral melalui hidden curriculum di sekolah.

\section{DAFTAR PUSTAKA}

Dokumen perangkat pembelajaran PAI SDN Sawotratap I Gedangan-Sidoarjo tahun pelajaran 2013/2014

Erma Pawitasari http://insistnet.com/enamprinsip-pendidikankarakter-islami/

Jane Martin, What Should We Do with a Hidden Curriculum When We Find One? dalam The Hidden Curriculum and Moral Education. Ed. Giroux, Henry, dan David Purpel. Berkeley, (California: McCutchan Publishing Corporation, 1983). 
Jeane H. Balantine, The Sociology of Education A Systematic Analysis (New Jersey: Intence Hall Inc, 1983).

Marzuki, Prinsip Dasar Pendidikan Karakter Perspektif Islam, PKn dan Hukum FISE UNY.

Michael Apple, "Hidden in Plain Sight, dalam Journal The Formal, Informal, and Hidden Curriculum of a Psychiatry Clerkship, Vol. 84 Nomor 2 (Mey, 2009).

Nasution, Pengembangan Kurikulum, Cet. IV (Bandung: PT. Citra Aditya Bakti, 1993).

Fulya Damla Kentli, "Comparison of Hidden Theories".

Observasi yang dilakukan oleh penulis di SDN Sawotratap I Gedangan-Sidoarjo pada Bulan Januari-Maret 2014.

Syafii Maarif, "Historiografi dan Pengajaran Sejarah. Makalah (Padang: FPIPS IKIP Padang, 1995). 


\title{
PENGEMBANGAN IPTEK DALAM TINJAUAN HUKUM ISLAM
}

\author{
Al Quddus Nofiandri Eko Sucipto Dwijo \\ (Dosen PAI FTK UIN Sunan Ampel)
}

\begin{abstract}
Abstrak:
Islam sangat mendukung umatnya untuk menemukan dan mengembangkan ilmu pengetahuan dan teknologi (Iptek). Dalam hal pengembangan Iptek, umat Islam dapat mempelajarinya dari orang-orang no-Islam, disamping juga dapat mengembangkan Iptek dari spirit ajaran Islam sendiri. Oleh karena produk keilmuan yang datang dari orang-orang non-Islam -secara umum- bersifat sekuleristik, maka setelah dipelajari, sebelum diadopsi dan diterpkan di dunia Islam, penting untuk terlebih dahulu diberikan nilainilai keislaman, agar tidak bertentangan dengan ajaranajaran hukum Islam. Ajaran hukum Islam secara normatif dan empirik sangat memulyakan orang-orang yang beriman dan berilmu dengan beberapa derajat. Dalam ajaran hukum Islam, ditegaskan bahwa tidak sama antara orang yang berilmu dengan orang yang tidak berilmu. Orang yang berilmu jelas lebih baik dan lebih utama daripada orang yang tidak berilmu. Dengan demikian, pengembagan ilmu pengetahuan dan teknologi dengan ragam modelnya (misal dengan bahasa Islamisasi Iptek) sangat dianjurkan oleh ajaran hukum Islam.
\end{abstract}

Kata Kunci: Ilmu, Islamisasi Ilmu, dan Hukum Islam 


\section{A. Pendahuluan}

Dalam masyarakat Islam, ilmu merupakan bagian yang tak terpisahkan dari nilai-nilai ketuhanan, karena sumber ilmu yang hakiki adalah Allah SWT. Manusia adalah ciptaan Allah SWT yang paling tinggi derajatnya dibandingkan dengan mahluk yang lain, karena manusia diberi daya berfikir, daya berfikir inilah yang menemukan teori-teori ilmiah dan teknologi. Pada waktu yang bersamaan, daya pikir tersebut menjadi bagian yang tak dapat dipisahkan dari keberadaan manusia sebagai makhluk Allah SWT. Oleh karenanya, manusia tidak hanya bertanggung jawab kepada sesamanya, tetapi juga kepada pencipta-Nya.

Meski begitu, perlu diingat bahwa ikatan agama yang terlalu kaku dan terstruktur kadang kala dapat menghambat perkembangan ilmu. Oleh karena itu, perlu kejelian dan kecerdasan memperhatikan sisi kebebasan dalam ilmu dan sistem nilai dalam agama agar keduanya tidak saling bertolak belakang. Di sinilah perlu rumusan yang jelas tentang ilmu secara filosofis, akademik dan agama agar ilmu dan teknologi tidak menjadi bagian yang lepas dari nilai-nilai agama dan kemanusiaan serta lingkungannya. ${ }^{1}$

Disamping itu, perlu dipertanyakan, apakah ilmu selalu merupakan berkah dan penyelamat bagi manusia? Apakah sudah terbukti, dengan kemajuan ilmu pengetahuan, manusia dapat menciptakan berbagai bentuk teknologi. Misalnya, pembuatan bom yang pada awalnya untuk memudahkan kerja manusia, namun kemudian dipergunakan untuk hal-hal yang bersifat negatif yang menimbulkan malapetaka bagi manusia itu sendiri. Di sinilah ilmu harus diletakkan secara proposional

\footnotetext{
${ }^{1}$ http://meetabied.wordpress.com/2009/11/01/kedudukan-filsafat-ilmu-dalamislamisasi-ilmu-pengetahuan-dan-kontribusinya-dalam-krisis-masyarakatmodern/ (Dikutip pada 14-12-2013).
} 
dan memihak pada nilai-nilai kebaikan dan kemanusiaan. Mengingat, jika ilmu tidak berpihak kepada nilai-nilai kebaikan, maka yang terjadi adalah bencana dan malapetaka.

Ide Islamisasi ilmu pengetahuan dan teknologi (Iptek) merupakan bagian dari upaya memberikan nilai-nilai Islam pada beragam keilmuan dengan ragam model pengembangannya. Beragam keilmuan dikembangkan dengan memberikan pandangan keislaman di dalamnya. Ide ini melahirkan pihakpihak yang pro dan kontra. Ada yang setuju dan ada yang kurang setuju. Dengan begitu, tidak ada salahnya jika ide Islamisasi Iptek ini ditinjau dari sisi hukum Islam.

\section{B. Konsep Iptek}

Ilmu adalah sesuatu yang diketahui secara ilmiah. Ilmu merupakan sesuatu yang penting bagi manusia, karena dengan ilmu semua keperluan dan kebutuhan manusia dapat terpenuhi secara lebih cepat dan lebih mudah. Merupakan kenyataan yang tidak dapat dipungkiri bahwa peradaban manusia sangat berhutang pada ilmu. Ilmu telah banyak mengubah wajah dunia seperti hal memberantas penyakit, kelaparan, kemiskinan dan berbagai wajah kehidupan yang sulit lainnya. Dengan kemajuan ilmu, manusia dapat merasakan kemudahan lainnya seperti transportasi, pemukiman, pendidikan, komunikasi, dan lain sebagainya. Singkatnya ilmu merupakan sarana untuk membantu manusia dalam mencapai tujuan hidupnya.

Setiap ilmu pengetahuan akan menghasilkan teknologi yang kemudian akan diterapkan pada masyarakat. Proses ilmu pengetahuan menjadi sebuah teknologi yang benar-benar dapat dimanfaatkan oleh masyarakat tentu tidak terlepas dari si ilmuwannya. Seorang ilmuwan akan dihadapkan pada kepentingan-kepentingan pribadi ataukah kepentingan masyarakat akan membawa pada persoalan etika keilmuan 
serta masalah bebas nilai. Untuk itulah tanggungjawab seorang ilmuwan harus dipupuk dan berada pada tempat yang tepat, tanggung jawab akademis, dan tanggung jawab moral. Penerapan ilmu pengetahuan yang telah dihasilkan oleh para ilmuwan, apakah itu berupa teknologi, ataupun teori-teori emansipasi masyarakat, mestilah memperhatikan nilai-nilai kemanusiaan, nilai agama, nilai adat, dan sebagainya. Ini berarti ilmu pengetahuan tersebut sudah tidak bebas nilai. karena ilmu sudah berada di tengah-tengah masyarakat luas dan masyarakat akan mengujinya.

Oleh karena itu, tanggung jawab lain yang berkaitan dengan teknologi di masyarakat, yaitu menciptakan hal yang positif. Akan tetapi, tidak semua teknologi atau ilmu pengetahuan selalu memiliki dampak positif. Di bidang etika, tanggung jawab seorang ilmuwan, bukan lagi memberi informasi namun harus memberi contoh. Dia harus bersifat objektif, terbuka, menerima kritik, menerima pendapat orang lain, kukuh dalam pendirian yang dianggap benar, dan berani mengakui kesalahan. Semua sifat ini, merupakan implikasi etis dari proses penemuan kebenaran secarah ilmiah. Di tengah situasi di mana nilai mengalami kegoncangan, maka seorang ilmuwan harus tampil ke depan. Pengetahuan yang dimilikinya merupakan kekuatan yang akan memberinya keberanian. ${ }^{2} \mathrm{Hal}$ yang sama harus dilakukan pada masyarakat yang sedang membangun, seorang ilmuwan harus bersikap sebagai seorang pendidik dengan memberikan contoh yang baik.

Ilmu pengetahuan harus terbuka pada konteksnya, dan agamalah yang menjadi konteksnya itu. Agama mengarahkan ilmu pengetahuan pada tujuan hakikinya, yakni memahami realitas alam, dan memahami eksistensi Allah SWT, agar

${ }^{2}$ Ibid. 
manusia menjadi sadar akan hakikat penciptaan dirinya. Solusi yang diberikan al-Quran terhadap ilmu pengetahuan yang terikat dengan nilai adalah dengan cara mengembalikan ilmu pengetahuan pada jalur semestinya, sehingga ia menjadi berkah dan rahmat kepada manusia dan alam, bukan sebaliknya, membawa mudharat.

Mengenai tujuan ilmu pengetahuan, ada beberapa perbedaan pendapat antara filosof dengan para ulama. Sebagian berpendapat bahwa pengetahuan sendiri merupakan tujuan pokok bagi orang yang menekuninya, dan mereka ungkapkan tentang hal ini dengan ungkapan, ilmu pengetahuan untuk ilmu pengetahuan, seni untuk seni, sastra untuk sastra, dan lain sebagainya. Menurut mereka ilmu pengetahuan hanyalah sebagai objek kajian untuk mengembangkan ilmu pengetahuan sendiri. Sebagian yang lain cenderung berpendapat bahwa tujuan ilmu pengetahuan merupakan upaya para peneliti atau ilmuwan menjadikan ilmu pengetahuan sebagai alat untuk menambahkan kesenangan manusia dalam kehidupan yang sangat terbatas dimuka bumi ini.

Menurut pendapat yang kedua ini, ilmu pengetahuan itu untuk meringankan beban hidup manusia atau untuk membuat manusia senang, karena dari lmu pengetahuan itulah yang nantinya akan melahirkan teknologi. Teknologi jelas sangat dibutuhkan oleh manusia untuk mengatasi berbagai masalah, dan lain sebagainya. Sementara itu pendapat yang lainnya cenderung menjadikan ilmu pengetahuan sebagai alat untuk meningkatkan kebudayaan dan kemajuan bagi umat manusia secara keseluruan. ${ }^{3}$

\footnotetext{
${ }^{3}$ Ibid.
} 


\section{Konsep Islamisasi Iptek}

Islamisasi ilmu pengetahuan pada dasarnya merupakan suatu respon terhadap krisis masyarakat modern yang disebabkan karena pendidikan Barat yang bertumpu pada suatu pandangan dunia yang lebih bersifat materialistis, sekularistis, relatifistis; yang menganggap bahwa pendidikan bukan untuk membuat manusia bijak, yakni mengenali dan mengakui posisi masing-masing dalam tertib realitas tapi memandang realitas sebagai sesuatu yang bermakna secara material bagi manusia, dan karena itu hubungan manusia dengan tertib realitas bersifat eksploitatif bukan harmonis. ${ }^{4}$ Ini adalah salah satu penyebab penting munculnya krisis masyarakat modern.

Islamisasi ilmu pengetahuan mencoba mencari akarakar krisis tersebut. Akar-akar krisis itu diantaranya dapat ditemukan dalam ilmu pengetahuan, yakni konsepsi atau asumsi tentang realitas yang dualistis, sekularistik, evolusioneristis, dan karena itu pada dasarnya bersifat realitifitas dan nihilistis. Islamisasi ilmu pengetahuan merupakan suatu upaya pembebasan pengetahuan dari asumsi-asumsi atau penafsiran-penafsiran Barat terhadap realitas, dan kemudian menggantikannya dengan pandangan dunia Islam.

Seperti apakah gagasan Islamisasi ilmu dapat dijalankan dan betul-betul menjadi solusi terhadap krisis masyarakat modern, barangkali sejarah yang akan membuktikannya. Apapun hasilnya nanti, gagasan ini perlu mendapat sambutan terutama dari mereka yang memiliki kepentingan dengan kondisi masyarakat modern. Selain itu Islamisasi ilmu

\footnotetext{
${ }^{4}$ Aminullah Elhady, "Naquib Al-Attas: Islamisasi Ilmu", dalam Khudlori Sholeh (Editor), Pemikiran Islam Kontemporer (Yogyakarta: Jendela, 2003), 331-332.
} 
pengetahuan juga muncul sebagai reaksi adanya konsep dikotomi antara agama dan ilmu pengetahuan yang dimasukkan masyarakat Barat dan budaya masyarakat modern. Masyarakat yang disebut terakhir ini misalnya memandang sifat, metode, struktur sains dan agama jauh berbeda, kalau tidak mau dikatakan kontradiktif. Sementara itu, sains meneropongnya dari segi objektifnya. Agama melihat problematika dan solusinya melalui petunjuk Allah SWT, sedangkan sains melalui eksprimen dan rasio manusia. Oleh karena ajaran agama diyakini sebagai petunjuk Allah SWT, kebenaran dinilai mutlak, sedangkan kebenaran sains relatif. Agama banyak berbicara yang gaib sedangkan sains hanya berbicara mengenai hal yang empiris.

Dalam perspektif sejarah, sains dan teknologi modern yang telah menunjukkan keberhasilannya dewasa ini mulai berkembang di Eropa dalam rangka gerakan renaissans pada tiga atau empat abad yang silam. Gerakan ini berhasil menyingkirkan peran agama dan mendobrak dominasi gereja Roma dalam kehidupan sosial dan intelektual masyarakat Eropa sebagai akibat dari sikap gereja yang memusuhi ilmu pengetahuan. ${ }^{5}$ Dengan kata lain ilmu pengetahuan di Eropa dan Barat mengalami perkembangan setelah memisahkan diri dari pengaruh agama. Setelah itu berkembanglah pendapatpendapat yang merendahkan agama dan meninggikan sains. Dalam perkembangannya, sains dan teknologi modern dipisahkan dari agama, karena kemajuaannya yang begitu pesat di Eropa dan Amerika sebagaimana yang disaksikan sampai sekarang. Sains dan teknologi yang demikian itu selanjutnya digunakan untuk mengabdi kepada kepentingan

\footnotetext{
${ }^{5}$ http://meetabied.wordpress.com/2009/11/01/kedudukan-filsafat-ilmu-dalamislamisasi-ilmu-pengetahuan-dan-kontribusinya-dalam-krisis-masyarakatmodern/ (Dikutip pada 14-12-2013).
} 
manusia semata-mata, yaitu untuk tujuan memuaskan hawa nafsunya, menguras isi alam untuk tujuan memuaskan nafsu konsumtif dan materialistik, menjajah dan menindas bangsabangsa yang lemah, melanggengkan kekuasaan dan tujuan lainnya.

Penyimpangan dari tujuan penggunaan ilmu pengetahuan itulah yang direspon melalui konsep Islamisasi ilmu pengetahuan, yaitu upaya menempatkan sains dan teknologi dalam bingkai Islam, dengan tujuan agar perumusan dan pemanfaatan sains dan teknologi itu ditunjukkan untuk mempertinggi harkat dan martabat manusia, melaksanakan fungsi kekhalifahannya di muka bumi serta tujuan-tujuan luhur lainnya. Inilah yang menjadi salah satu misi Islamisasi ilmu pengetahuan.

Berdasarkan penelusuran yang dilakukan oleh Ummi ${ }^{6}$ di UIN Malang, ditemukan beberapa versi pemahaman tentang Islamisasi ilmu pengetahuan dan teknologi. Pertama beranggapan bahwa Islamisasi ilmu pengetahuan merupakan sekedar memberikan ayat-ayat yang sesuai dengan ilmu pengetahuan dan teknologi umum yang ada (ayatisasi). Kedua, mengatakan bahwa Islamisasi dilakukan dengan cara mengislamkan orangnya. Ketiga, Islamisasi yang berdasarkan filsafat Islam yang juga diterapkan di UIN Malang dengan mempelajari dasar metodologinya. Keempat memahami Islamisasi sebagai sebuah ilmu pengetahuan yang beretika atau beradab. Dengan berbagai pandangan dan pemaknaan yang muncul secara beragam ini perlu kiranya untuk diungkap agar lebih dipahami apa yang dimaksud "Islamisasi Ilmu Pengetahuan dan teknologi".

6 Ummi, Islamisasi Sains Perspektif UIN Malang, dalam Inovasi: Majalah Mahasiswa UIN Malang, Edisi 22. Th. 2005. 
Ismail Raji Al-Faruqi menyatakan bahwa Islamisasi adalah usaha "untuk mendefinisikan kembali, menyusun ulang data, memikirkan kembali argumen dan rasionalisasi yang berkaitan dengan data itu, menilai kembali kesimpulan dan tafsiran, memproyeksikan kembali tujuan-tujuan dan melakukan semua itu sedemikian rupa sehingga disiplindisiplin ini memperkaya wawasan Islam dan bermanfaat bagi cita-cita. ${ }^{7}$ Untuk menuangkan kembali keseluruhan khazanah pengetahuan umat manusia menurut wawasan Islam, bukanlah tugas yang ringan yang harus dihadapi oleh intelektualintelektual dan pemimpin-pemimpin Islam saat ini. Oleh karena itulah, untuk melandingkan gagasannya tentang Islamisasi ilmu, al-Faruqi meletakkan "prinsip tauhid" sebagai kerangka pemikiran, metodologi dan cara hidup Islam. Prinsip tauhid ini dikembangkan oleh al-Faruqi menjadi lima (5) macam kesatuan, yaitu: (1) Kesatuan Tuhan, (2) Kesatuan ciptaan, (3) Kesatuan kebenaran dan Pengetahuan, (4) Kesatuan kehidupan, dan (5) Kesatuan kemanusiaan. ${ }^{8}$

Islamisasi ilmu dimaksudkan untuk memberikan respon positif terhadap realitas ilmu pengetahuan modern yang sekularistik dan Islam yang "terlalu" religius, dalam model pengetahuan baru yang utuh dan integral tanpa pemisahan di antaranya. Sebagai panduan untuk usaha tersebut, al-Faruqi menggariskan satu kerangka kerja dengan lima tujuan dalam rangka Islamisasi ilmu, tujuan yang dimaksud adalah: 1. Penguasaan disiplin ilmu modern. 2. Penguasaan khazanah warisan Islam. 3. Membangun relevansi Islam dengan masingmasing disiplin ilmu modern. 4. Memadukan nilai-nilai dan khazanah warisan Islam secara kreatif dengan ilmu-ilmu

\footnotetext{
${ }^{7}$ Ismail Raji Al-Faruqi, Islamisasi Pengetahuan (Bandung: Pustaka, 1984).

${ }^{8}$ Ibid. 
modern. 5. Pengarahan aliran pemikiran Islam ke jalan-jalan yang mencapai pemenuhan pola rencana Allah SWT. ${ }^{9}$

Selain itu, ada beberapa pengembangan definisi dari Islamisasi ilmu pengetahuan dan teknologi tersebut. Sebagaimana yang diungkapkan oleh Osman Bakar, ${ }^{10}$ Islamisasi ilmu pengetahuan dan teknologi adalah sebuah program yang berupaya memecahkan masalah-masalah yang timbul karena perjumpaan antara Islam dengan sains modern sebelumnya. Progam ini menekankan pada keselarasan antara Islam dan sains modern tentang bagaimana sains dapat bermanfaat bagi umat Islam. M. Zainuddin ${ }^{11}$ menyimpulkan bahwa Islamisasi pengetahuan pada dasarnya adalah upaya pembebasan pengetahuan dari asumsi-asumsi Barat terhadap realitas dan kemudian menggantikannya dengan worldview-nya sendiri (Islam).

Sejak digagasnya ide Islamisasi ilmu pengetahuan oleh para cendikiawan muslim dan telah berjalan lebih dari 30 tahun, jika dihitung dari Seminar Internasional pertama tentang Pendidikan Islam di Makkah pada tahun 1977, berbagai respon terhadapnya pun mulai bermunculan, baik yang mendukung ataupun menolak, usaha untuk merealisasikan pun secara perlahan semakin marak dan beberapa karya yang berkaitan dengan ide Islamisasi mulai bermunculan di dunia Islam. Al-Attas sendiri sebagai penggagas ide ini telah menunjukkan suatu model usaha Islamisasi ilmu melalui karyanya, The Concept of Education in Islam. Dalam teks ini beliau berusaha menunjukkan hubungan antara bahasa dan pemikiran. Beliau menganalisis istilah-

\footnotetext{
${ }^{9}$ Ibid.

${ }^{10}$ Osman Bakar, Tauhid dan Sains (Bandung: Pustaka Hidayah, 1994)

${ }^{11}$ M. Zainuddin, Filsafat Ilmu: Perspektif Pemikiran Islam (Malang: Bayu Media, 2003).
} 
istilah yang sering dimaksudkan untuk mendidik seperti ta'lim, tarbiyah dan ta'dib, dan akhirnya mengambil kesimpulan bahwa istilah $t a^{\prime} d i b$ merupakan konsep yang paling sesuai dan komprehensif untuk pendidikan. ${ }^{12}$

Usaha ini kemudian dilanjutkan oleh cendekiawan muslim lainnya, sebut saja seperti Malik Badri (Dilema of a Muslim Psychologist, 1990); Wan Mohd Nor Wan Daud (The Concept of Knowledge in Islam,1989); dan Rosnani Hashim (Educational Dualism in Malaysia: Implications for Theory and Practice, 1996). Usaha dalam bidang psikologi seperti yang dilakukan Hanna Djumhana B. dan Hasan Langgulung, di bidang ekonomi Islam seperti Syafi'i Antonio, Adiwarman, Mohammad Anwar dan lain-lain. Bahkan hingga sekarang tercatat sudah lebih ratusan karya yang dihasilkan yang berbicara tentang Islamisasi ilmu pengetahuan, baik dalam bentuk buku, jurnal, majalah, artikel dan sebagainya. ${ }^{13}$

Setelah mengalami perjalanan yang cukup panjang, Islamisasi ilmu pengetahuan ini dinilai oleh beberapa kalangan belum memberikan hasil yang konkrit dan kontribusi yang berarti bagi umat Islam. Bahkan secara lugas editor American Journal of Islamic Social Sciences (AJISS) mengakui bahwa meskipun telah diadakan enam kali konferensi mengenai pendidikan Islam, yaitu di Makkah (1977), Islamabad (1980), Dakka (1981), Jakarta (1982), Kairo (1985), dan Amman (1990), dan berdirinya beberapa universitas yang memfokuskan pada Islamisasi pendidikan, namun hingga saat ini, tugas untuk menghasilkan silabus sekolah, buku-buku teks,

12 Miftahul Huda, Historisitas Islamisasi Ilmu Pengetahuan, dalam http://drmiftahulhudauin. multiply.com/journal/item/13 (Dikutip pada 14-122013).

${ }^{13}$ Ibid. 
dan petunjuk yang membantu guru di sekolah belum dilakukan. ${ }^{14}$

Berdasarkan identifikasi Hanna Djumhana Bastaman, setelah cukup lama berkembang, Islamisasi melahirkan beberapa bentuk pola pemikiran, mulai dari bentuk yang paling superfisial sampai dengan bentuk yang agak mendasar. Bastaman mengistilahkannya sebagai; 1) Similarisasi, yaitu menyamakan begitu saja konsep-konsep yang berasal dari agama, padahal belum tentu sama; 2) Paralelisasi, yaitu menganggap paralel konsep yang berasal dari sains karena kemiripan konotasinya, tanpa mengidentikkan keduanya; 3) Komplementasi, yaitu antara sains dan agama saling mengisi dan saling memperkuat satu sama lain dengan tetap mempertahankan eksistensinya masing-masing; 4) Komparasi, yaitu membandingkan konsep/teori sains dengan konsep/wawasan agama mengenai gejala-gejala yang sama; 5) Induktifikasi, yaitu asumsi-asumsi dasar dari teori-teori ilmiah yang didukung oleh temuan-temuan empirik dilanjutkan pemikirannya secara teoritis-abstrak ke arah pemikiran metafisik, kemudian dihubungkan dengan prinsip-prinsip agama dan al-Quran mengenai hal tersebut; dan 6) Verifikasi, yaitu mengungkapkan hasil-hasil penelitian ilmiah yang menunjang dan membuktikan kebenaran ayat-ayat al-Quran. ${ }^{15}$

Keenam pola pemikiran yang diidentifikasi Bastaman di atas, masih menampakkan jurang pemisah antara keduanya, agama yang pada dasarnya bersumber dari keimanan yang bersifat metafisik tidak begitu saja dapat dihubungkan dengan

\footnotetext{
${ }^{14}$ Wan Mohd Nor Wan Daud, The Educational Philosophy and Practice of Syed Muhammad Naquib al-Attas, diterjemahkan oleh Hamid Fahmy dkk, Filsafat dan Praktik Pendidikan Islam Syed M. Naquib al-Attas (Bandung: Mizan, 1998).

15 Hanna Djumhana Bastaman, Integrasi Psikologi dengan Islam: Menuju Psikologi Islami (Yogyakarta: Pustaka Pelajar, 1997).
} 
ilmu pengetahuan yang lebih bercorak empirik dan merupakan produk akal dan intelektual manusia. Walau demikian, polapola pemikiran tersebut harus tetap dihargai sebagai upaya untuk Islamisasi ilmu pengetahuan. ${ }^{16}$

Konsep Islamisasi ilmu ini tidak hanya bisa diterapkan oleh umat Islam. Masyarakat non-Muslim pun bisa menyerapnya. Konsep Islamisasi bukanlah Arabisasi. Memang Islam bermula dari kandungan bahasa Arab. Islam adalah agama yang alami, bisa masuk ke seluruh dunia, bangsa, dan bahasa. Untuk setiap bangsa yang ingin memahami agama Islam, memang harus memahami bahasa Arab saat mempelajari kandungan ayat al-Quran. Akan tetapi, Islamisasi bukan Arabisasi. Islamisasi tidak sama dengan peng-araban. Walaupun untuk mengamalkan Islam tidak jauh dari budaya Arab, tapi bukan berarti budaya Arab yang dipahami itu Islam. Selain bukan Arabisasi, Islamisasi ilmu tidak berarti menolak budaya Barat. Islamisasi ilmu justru memasukkan berbagai hal penting dari budaya Barat ke dalam pandangan Islam. Tentunya, harus dalam rangka membentuk akhlak dan syariat Islami. $^{17}$

\section{Sejarah Islamisasi Iptek}

Wan Mohd Nor Wan Daud menyatakan bahwa proses Islamisasi ilmu pengetahuan dan teknologi pada dasarnya telah berlangsung sejak masa permulaan Islam hingga zaman sekarang ini. Ayat-ayat terawal yang diwahyukan kepada Nabi secara jelas menegaskan semangat Islamisasi ilmu

\footnotetext{
16 Miftahul Huda, Historisitas Islamisasi Ilmu Pengetahuan, dalam http:// drmiftahulhudauin. multiply.com/journal/item/13 (Dikutip pada 14-12-2013). 17 Wan Mohd Nor Wan Daud, Akhlak Mulia Lewat Islamisasi Ilmu, dalam http://www.mail-archive.com/daarut-tauhiid@yahoogroups.com/msg06276. html (Dikutip pada 14-12-2013).
} 
pengetahuan dan teknologi kontemporer, yaitu ketika Allah SWT menekankan bahwa Dia adalah sumber dan asal ilmu manusia. Ide yang disampaikan al-Quran tersebut membawa suatu perubahan radikal dari pemahaman umum bangsa Arab pra-Islam, yang menganggap suku dan tradisi kesukuan serta pengalaman empiris, sebagai sumber ilmu pengetahuan dan kebijaksanaan. $^{18}$

Pada masa pemerintahan Daulah Bani Abbasiyah (sekitar abad ke-8 M), proses Islamisasi ilmu ini berlanjut secara besar-besaran, yaitu dengan dilakukannya penerjemahan terhadap karya-karya dari Persia dan Yunani yang kemudian diberikan pemaknaan ulang disesuaikan dengan konsep agama Islam. Salah satu karya besar tentang usaha Islamisasi ilmu adalah hadirnya karya Imam al-Ghazali, Tahafut al-Falasifah, yang menonjolkan 20 ide yang asing dalam pandangan Islam yang diambil oleh pemikir Islam dari falsafah Yunani, beberapa di antara ide tersebut bertentangan dengan ajaran Islam yang kemudian dibahas oleh al-Ghazali disesuaikan dengan konsep aqidah Islam. Hal yang sedemikian tersebut, walaupun tidak menggunakan pelabelan Islamisasi, tapi aktivitas yang sudah dilakukan senafas dengan makna Islamisasi. $^{19}$

Selain itu, pada tahun 1930-an, Muhammad Iqbal menegaskan akan perlunya melakukan proses Islamisasi terhadap ilmu pengetahuan. Dia menyadari bahwa ilmu yang dikembangkankan oleh Barat telah bersifat ateistik, sehingga bisa menggoyahkan aqidah umat, sehingga beliau menyarankan umat Islam agar "mengonversikan ilmu pengetahuan modern". Akan tetapi, Iqbal tidak melakukan

\footnotetext{
${ }^{18}$ Wan Mohd Nor Wan Daud, The Educational Philosophy ... Op.Cit.

19 Miftahul Huda, Historisitas Islamisasi Ilmu Pengetahuan, dalam http:// drmiftahulhudauin. multiply.com/journal/item/13 (Dikutip pada 14-12-2013).
} 
tindak lanjut atas ide yang dilontarkannya tersebut. Tidak ada identifikasi secara jelas problem epistemologis mendasar dari ilmu pengetahuan modern Barat yang sekuler itu, dan juga tidak mengemukakan saran-saran atau program konseptual atau metodologis untuk megonversikan ilmu pengetahuan tersebut menjadi ilmu pengetahuan yang sejalan dengan Islam.

Ide Islamisasi ilmu pengetahuan ini dimunculkan kembali oleh Sayyed Hossein Nasr, pemikir muslim Amerika kelahiran Iran, tahun 60-an. Dia menyadari akan adanya bahaya sekularisme dan modernisme yang mengancam dunia Islam, karena itulah beliau meletakkan asas untuk konsep sains Islam dalam aspek teori dan praktikal melalui karyanya Science and Civilization in Islam (1968) dan Islamic Science (1976). Nasr mengklaim bahwa ide-ide Islamisasi yang muncul kemudian merupakan kelanjutan dari ide yang pernah dilontarkannya. ${ }^{20}$

Gagasan tersebut kemudian dikembangkan oleh Naquib Al-Attas sebagai proyek "Islamisasi" yang mulai diperkenalkannya pada Konferensi dunia mengenai Pendidikan Islam yang Pertama di Makkah pada tahun 1977. Al-Attas dianggap sebagai orang yang pertama kali mengupas dan menegaskan tentang perlunya Islamisasi pendidikan, Islamisasi sains, dan Islamisasi ilmu. Dalam pertemuan itu beliau menyampaikan makalah yang berjudul "Preliminary Thoughts on the Nature of Knowledge and the Definition and Aims of Education". Ide ini kemudian disempurnakan dalam bukunya Islam and Secularism (1978) dan The Concepts of Education in Islam A Framework for an Islamic Philosophy of Education (1980). Persidangan inilah yang kemudian dianggap sebagai pembangkit proses Islamisasi selanjutnya. ${ }^{21}$

${ }^{20}$ Ibid.

${ }^{21}$ Ibid. 
Gagasan awal dan saran-saran konkret yang diajukan alAttas, tak pelak, mengundang pelbagai reaksi dan salah satunya adalah Ismail Raji al-Faruqi dengan agenda Islamisasi Ilmu Pengetahuannya. Sampai saat ini gagasan Islamisasi ilmu menjadi misi dan tujuan terpenting (raison d'etre) bagi beberapa institusi Islam seperti International Institute of Islamic Thought (IIIT), International Islamic University Malaysia (IIUM), Akademi Islam di Cambridge dan International Institute of Islamic Thought and Civilization (ISTAC) di Kuala Lumpur.

\section{E. Strategi Pengembangan Islamisasi Iptek}

Pemisahan agama dari ilmu pengetahuan sebagaimana tersebut di atas terjadi pada abad pertengahan, yaitu pada saat umat Islam kurang mempedulikan (meninggalkan) iptek. Pada masa itu yang berpengaruh di masyarakat Islam adalah ulama tarikat dan ulama fiqih. Keduanya menanamkan paham taklid dan membatasi kajian agama hanya dalam bidang yang sampai sekarang masih dikenal sebagai ilmu-ilmu agama seperti tafsir, fiqih,dan tauhid. Ilmu tersebut mempunyai pendekatan normatif dan tarekat, tarekat hanyut dalam wirit dan dzikir dalam rangka menyucikan jiwa dan mendekatkan diri pada Allah SWT dengan menjauhkan kehidupan duniawi.

Beberapa ulama tidak tertarik mempelajari alam dan kehidupan manusia secara objektif; bahkan ada yang mengharamkan untuk mempelajari filsafat, padahal dari filsafatlah iptek dapat berkembang pesat. Keadaan ini mengalami perubahan pada akhir abad ke-19, yaitu sejak ideide pembaharuan diterima dan didukung oleh sebagian umat. Mereka mengkritik pengembangan sains dan teknologi modern yang dipisahkan dari ajaran agama, seperti dikemukakan oleh Muhammad Naquib al-Attas (1981: 47-56) Ismail Raji al-Faruqi 
(1982: 3-8) dengan tujuan agar ilmu pengetahuan dapat membawa kepada kesejahteraan bagi umat manusia.

Para ilmuwan dan cendekiawan muslim menganggap bahwa pengembangan iptek perlu dikembalikan pada kerangka dan perspektif ajaran Islam. Al-Faruqi menyerukan perlunya dilaksanakan Islamisasi sains. Sejak itu gerakan Islamisasi ilmu pengetahuan digulirkan, dan kajian mengenai Islam dalam hubungannya dengan pengembangan iptek mulai digali dan diperkenalkan. ${ }^{22}$ Sebagaimana diketahui bahwa salah satu gagasan yang paling canggih, amat komperhensif dan mendalam yang ditemukan dalam al-Qur'an ialah konsep 'ilm. Pentingnya konsep ini terungkap dalam kenyataan turunnya sekitar 800 kali. Dalam sejarah peradaban Islam, konsep ilmu secara mendalam meresap ke dalam seluruh lapisan masyarakat dan mengungkapkan dirinya dalam semua upaya intelektual. Tidak ada peradaban lain yang memiliki konsep pengetahuan dengan semangat yang sedemikian tinggi dan mengajarkannya dengan amat tekun seperti itu.

Munawar Ahmad Aness menyatakan bahwa dalam konsep Islam yang berdasarkan al-Qur'an, upaya menerjemahkan ilmu sebagai pengetahuan berarti melakukan suatu kejahatan. Walaupun tidak disengaja, terhadap konsep yang luhur dan multi dimensional ini. Ilmu memang mengandung unsur-unsur dari apa yang dipahami sekarang sebagai pengetahuan. Akan tetapi ia juga digambarkan sebagai hikmah. Selanjutnya jika di Eropa sains dan teknologi dapat berkembang sesudah mengalahkan dominasi gereja, sedangkan dalam perjalanan sejarah Islam, ilmu dalam berbagai bidangnya mengalaami kemajuan yang pesat di dunia Islam

\footnotetext{
${ }^{22}$ http://meetabied.wordpress.com/2009/11/01/kedudukan-filsafat-ilmu-dalamislamisasi-ilmu-pengetahuan-dan-kontribusinya-dalam-krisis-masyarakatmodern/ (Dikutip pada akses 14-12-2013).
} 
pada zaman klasik (670-1300 M), yaitu zaman Nabi Muhammad sampai dengan akhir masa Daulah Abbasiyah di Baghdad.

Pada masa itu, dunia Islam telah memainkan peran penting baik dalam bidang ilmu pengetahuan agama maupun pengetahuan umum. Dalam kaitan ini Harun Nasution menyatakan bahwa cendikiawan-cendikiawan muslim bukan hanya mempelajari ilmu pengetahuan dan filsafat dari bukubuku Yunani, tetapi hal itu mereka tambahkan ke dalam hasilhasil penyelidikan yang dilakukan sendiri dalam lapangan ilmu pengetahuan dan hasil pikiran mereka dalam ilmu filsafat. Para ilmuwan tersebut memiliki pengetahuan yang bersifat integrated, yakni bahwa ilmu pengetahuan umum yang mereka kembangakan tidak terlepas dari ilmu agama atau tidak terlepas dari nilai-nilai Islam.

Dalam rangka pengembangan Islamisasi Iptek, Al-Faruqi menyusun 12 langkah yang harus ditempuh terlebih dahulu. Langkah-langkah tersebut adalah: 1 . Penguasaan disiplin ilmu modern: prinsip, metodologi, masalah, tema dan perkembangannya. 2. Survei disiplin ilmu. 3. Penguasaan khazanah Islam: ontologi. 4. Penguasaan khazanah ilmiah Islam: analisis. 5. Penentuan relevansi Islam yang khas terhadap disiplin-disiplin ilmu. 6. Penilaian secara kritis terhadap disiplin keilmuan modern dan tingkat perkembangannya di masa kini. 7. Penilaian secara kritis terhadap khazanah Islam dan tingkat perkembangannya dewasa ini. 8. Survei permasalahan yang dihadapi umat Islam. 9. Survei permasalahan yang dihadapi manusia. 10. Analisis dan sintesis kreatif. 11. Penuangan kembali disiplin ilmu 
modern ke dalam kerangka Islam. 12. Penyebarluasan ilmu yang sudah diislamkan. ${ }^{23}$

Untuk mengaplikasikan Islamisasi ilmu, dapat dimulai dari level ilmu yang ada di perguruan tinggi. Level TK sampai SMA juga penting, tapi mereka sebenarnya bergantung pada guru-guru yang mengajar mereka. Guru yang mengajar TK sampai SMA, semuanya produk dari perguruan tinggi. Penulispenulis buku pun kebanyakan dibuat oleh (lulusan) perguruan tinggi. Jadi, walaupun targetnya sekolah dasar, yang harus diubah pertama adalah guru-gurunya. Di Malaysia, proses Islamisasi mulai berlaku dalam hal tertentu, karena politik kerajaan di Malaysia memberikan perhatian khusus pada masalah pendidikan. Di Indonesia pun usaha-usaha untuk menerapkan pandangan Islam sudah ada. ${ }^{24}$

\section{F. Pengembangan Iptek dalam Tinjauan Hukum Islam}

Berdasarkan tinjauan hukum Islam ilmu tidaklah berkembang pada arah yang tak terkendali, tapi ia harus bergerak pada arah maknawi dan umat manusia berkuasa untuk mengendalikannya. Kekuasaan manusia atas ilmu pengetahuan dan teknologi harus mendapatkan tempat yang utuh. Eksistensi ilmu pengetahuan dan teknologi bukan melulu untuk mendesak kemanusiaan, tetapi kemanusiaanlah yang menggenggam ilmu pengetahuan untuk kepentingan dirinya dalam rangka penghambaan diri kepada sang Pencipta.

Konsep ajaran Islam tentang pengembangan ilmu pengetahuan dan teknologi yang demikian itu didasarkan kepada beberapa prinsip sebagai berikut. ${ }^{25}$

\footnotetext{
${ }^{23}$ Al-Faruqi, Islamisasi...Op.Cit.

${ }^{24}$ Ibid.

${ }^{25}$ Ibid. 
Pertama, ilmu pengetahuan dan teknologi dalam Islam dikembangkan dalam kerangka tauhid atau teologi. Teologi yang bukan semata-mata meyakini adanya Allah SWT dalam hati, mengucapkannya dengan lisan dan mengamalkannya dengan tingkah laku, melainkan teologi yang menyangkut aktivitas mental berupa kesadaran manusia yang paling dalam perihal hubungan manusia dengan Tuhan, lingkungan dan sesamanya. Lebih tegasnya adalah teologi yang memunculkan kesadaran, yakni suatu "matra yang paling dalam" dari diri manusia yang menformat pandangan dunianya, yang kemudian menurunkan pola sikap dan tindakan yang selaras dengan pandangan dunia itu. Oleh karena itu teologi pada ujungnya akan mempunyai implikasi yang sangat sosiologis, sekaligus antropologis.

Kedua, ilmu pengetahuan dan teknologi dalam Islam hendaknya dikembangkan dalam rangka bertakwa dan beribadah kepada Allah SWT. Hal ini penting ditegaskan, karena dorongan al-Qur'an untuk mempelajari fenomena alam dan sosial tampak kurang diperhatikan, sebagai akibat dan dakwah Islam yang semula lebih tertuju untuk memperoleh keselamatan di akhirat. Hal ini mesti diimbangi dengan perintah mengabdi kapada Allah SWT dalam arti yang luas, termasuk mengembangkan Iptek.

Ketiga, Ilmu pengetahuan dan teknologi harus dikembangkan oleh orang-orang Islam yang memilki keseimbangan antara kecerdasan akal, kecerdasan emosional dan sepiritual yang dibarengi dengan kesungguhan untuk beribadah kepada Allah SWT dalam arti yang seluas-luasnya. Hal ini sesuai dengan apa yang terjadi dalam sejarah di abad klasik, dimana para ilmuwan yang mengembangkan ilmu pengetahuan adalah pribadi-pribadi yang senantiasa taat beribadah kepada Allah SWT. 
Keempat, Ilmu pengetahuan dan teknologi harus dikembangkan dalam kerangka yang integral, yakni bahwa antara ilmu agama dan ilmu umum walaupun bentuk formalnya berbeda-beda, namun hakikatnya sama, yaitu samasama sebagai tanda kekuasaan Allah SWT. Dengan pandangan yang demikian itu, maka tidak ada lagi perasaan yang lebih unggul antara satu dan lainnya. Dengan menerapkan keempat macam setrategi pengembangan ilmu pengetahuan tersebut, maka akan dapat diperoleh keuntungan yang berguna untuk mengatasi problem kehidupan masyarakat modern sebagaimana tersebut di atas.

Malaysia lebih memperhatikan pendidikan Islami. Misalnya, dalam hal yang melanggar tata krama. Kalau pejabat itu beragama Islam, mereka wajib merencanakan kemajuan Islamisasi ilmu yang akan berdampak pada akhlak masyarakatnya. Dalam menerapkan konsep Islamisasi ilmu tidak boleh mencampakkan hak orang yang bukan Islam. Mereka harus diperlakukan seadilnya. Begitu juga jangan sampai untuk menjaga hak non-Islam, hak orang Islam sendiri malah dikorbankan. Masyarakat non-Islam sendiri tidak perlu khawatir dengan Islamisasi ilmu. Kalau Islamisasi berjalan baik, semua umat apa pun agamanya akan mendukung. Kalau Islamisasi sukses, akan menjamin umat Islam lebih berakhlak dan akan lebih menjamin hak-hak ekonomi serta politik semua umat, termasuk non-Muslim. Kalau memiliki akhlak yang baik dan bisa menjaga hati nurani, masyarakat tidak akan memilih pemimpin yang rusak, sehingga semua negara akan dipimpin oleh pemimpin yang baik. 


\section{G. Penutup}

Dari uraian di atas dapat ditegaskan bahwa Islam sangat mendukung umatnya untuk menemukan dan mengembangkan ilmu pengetahuan dan teknologi (Iptek). Dalam hal pengembangan Iptek, umat Islam dapat mempelajarinya dari orang-orang no-Islam, disamping juga dapat mengembangkan Iptek dari spirit ajaran Islam sendiri. Oleh karena produk keilmuan yang datang dari orang-orang non-Islam -secara umum- bersifat sekuleristik, maka setelah dipelajari, sebelum diadopsi dan diterpkan di dunia Islam, penting untuk terlebih dahulu diberikan nilai-nilai keislaman, agar tidak bertentangan dengan ajaran-ajaran hukum Islam.

Ajaran hukum Islam secara normatif dan empirik sangat memulyakan orang-orang yang beriman dan berilmu dengan beberapa derajat. Dalam ajaran hukum Islam, ditegaskan bahwa tidak sama antara orang yang berilmu dengan orang yang tidak berilmu. Orang yang berilmu jelas lebih baik dan lebih utama daripada orang yang tidak berilmu. Dengan demikian, pengembagan ilmu pengetahuan dan teknologi dengan ragam modelnya (misal dengan bahasa Islamisasi Iptek) sangat dianjurkan oleh ajaran hukum Islam.

\section{DAFTAR PUSTAKA}

Aminullah Elhady, "Naquib Al-Attas: Islamisasi Ilmu", dalam Khudlori Sholeh (Editor), Pemikiran Islam Kontemporer (Yogyakarta: Jendela, 2003).

Hanna Djumhana Bastaman, Integrasi Psikologi dengan Islam: Menuju Psikologi Islami (Yogyakarta: Pustaka Pelajar, 1997). 
http://meetabied.wordpress.com/2009/11/01/kedudukan-filsafat-ilmudalam-islamisasi-ilmu-pengetahuan-dan-kontribusinyadalam-krisis-masyarakat-modern/ (Dikutip pada 14-122013).

Ismail Raji Al-Faruqi, Islamisasi Pengetahuan (Bandung: Pustaka, 1984).

M. Zainuddin, Filsafat Ilmu: Perspektif Pemikiran Islam (Malang: Bayu Media, 2003).

Miftahul Huda, Historisitas Islamisasi Ilmu Pengetahuan, dalam http://drmiftahulhudauin. multiply.com/journal/item/13 (Dikutip pada 14-12-2013).

Osman Bakar, Tauhid dan Sains (Bandung: Pustaka Hidayah, 1994)

Ummi, Islamisasi Sains Perspektif UIN Malang, dalam Inovasi: Majalah Mahasiswa UIN Malang, Edisi 22. Th. 2005.

Wan Mohd Nor Wan Daud, Akhlak Mulia Lewat Islamisasi Ilmu, dalam http://www.mail-archive.com/daaruttauhiid@yahoogroups.com/msg06276.html_ (Dikutip pada 14-12-2013).

Wan Mohd Nor Wan Daud, The Educational Philosophy and Practice of Syed Muhammad Naquib al-Attas, diterjemahkan oleh Hamid Fahmy dkk, Filsafat dan Praktik Pendidikan Islam Syed M. Naquib al-Attas (Bandung: Mizan, 1998). 


\title{
REDEFINISI PERAN GURU MENUJU PENDIDIKAN ISLAM BERMUTU
}

\author{
Mukani \\ (Dosen STIT Urwatul Wutsqo Jombang \& STAI Darussalam \\ Nganjuk)
}

\begin{abstract}
Abstrak:
Dikotomi seculer science dan religious science merubah pola pikir masyarakat muslim dalam beragama. Dari periode klasik yang memandang Islam sebagai ajaran komprehensif, berubah menjadi sebuah pemahaman yang memandang Islam sebagai agama yang hanya berorientasi kepada ritual. Dipahami bahwa pendidikan adalah proses yang memiliki continuity dan secara sadar dilakukan untuk mempersiapkan generasi yang memiliki pengetahuan dan nilai secara seimbang. Di sisi lain, dampak negatif dari kehidupan modern tidak dapat dihindari lagi oleh manusia modern, terutama dari aspek pendidikan. Untuk itu, berbagai unsur pada pendidikan harus terus menjaga keterkaitan yang telah ada untuk mencapai tujuan yang telah ditetapkan. Partisipasi dan kepedulian masyarakat yang masih rendah terhadap kemajuan dunia pendidikan harus diakhiri, seiring realisasi konsep school based management atau SBM. Aspek lain yang harus disiapkan adalah kualitas guru. Secara konsepsional, guru memiliki tiga fungsi, yaitu kognitif, moral dan inovatif. Agar menjadi sosok ideal di Indonesia, guru harus memenuhi delapan indikator, yaitu prinsip teologis, prinsip formal, prinsip fungsional, prinsip kultural, prinsip komprehensivitas, prinsip subtstansial, prinsip sosial dan prinsip identitas.
\end{abstract}

Kata Kunci: Problematika Pendidikan, Peran Guru, dan Reformulasi Filsafat Pendidikan 


\section{A. Pendahuluan}

Dalam periode emas, peradaban Islam telah menunjukkan diri sebagai suatu kekuatan sosial-politik yang mampu menguasai dua per tiga wilayah di bumi ini. ${ }^{1}$ Peradaban yang mulai dirintis sejak zaman Nabi Muhammad SAW tersebut, perlahan tetapi pasti, berjalan menembus dan menguasai pusat-pusat peradaban yang ada di sekitar Semenanjung Arab. Byzantium dan Persia (Iran), dua kekuatan raksasa yang ketika itu sangat berpengaruh dalam dunia internasional, ternyata tidak mampu membendung arus deras peradaban Islam yang mulai dikembangkan oleh Dinasti Umayyah dan mencapai masa puncak kejayaannya pada periode Dinasti Abasiyyah.

Meskipun suksesi kepemimpinan dari Dinasti Umayyah ke Dinasti Abasiyyah masih menyisakan berbagai masalah, yang mencapai puncaknya ketika Abdurrahman al-Dakhil mendirikan Dinasti Umayyah II di Andalusia Spanyol, namun Dinasti Abasiyyah tetap menunjukkan eksistensi dan supremasinya dalam membangun peradaban Islam. Kesuksesan Dinasti Abasiyyah ini merupakan hasil dari perhatian yang serius terhadap pertumbuhan dan perkembangan dunia pendidikan.

Ketika itu, pendidikan lebih tepat disebut sebagai tink tank peradaban. Di samping sebagai instrumen terpenting dalam membangun dan menjaga eksistensi sebuah peradaban, pendidikan juga merupakan aspek teologis yang harus dilaksanakan oleh semua orang Islam. Artinya, menuntut ilmu dalam pendidikan untuk menjadi orang yang mampu menunjukkan keislamannya dan memiliki integritas moral dan

${ }^{1}$ Harun Nasution, Pembaharuan Dalam Islam (Jakarta : Bulan Bintang, 1992), 13. 
sosial yang tinggi, hukumnya adalah wajib 'ain bagi setiap Muslim. Dalam QS. al-Mujadalah: 11, Allah SWT sendiri telah menunjukkan komitmen-Nya untuk mengangkat derajat orangorang yang berilmu. Meski demikian, pendidikan akan mengikuti proses perjalanan historis yang pasti mengalami maju mundur dalam perkembangannya. Kemunduran dalam dunia pendidikan ini, secara disengaja atau tidak, akan mengakibatkan kemunduran peradaban Islam itu sendiri. Inilah yang oleh Mughni diidentifikasikan sebagai sebuah awal dari abad pertengahan yang gelap bagi perkembangan peradaban Islam. ${ }^{2}$

Kemunduran peradaban Islam yang secara terus menerus berimplikasi kepada kemunduran peradaban Islam dan dalam waktu cukup lama, telah mengakibatkan berbagai kekalahan masyarakat muslim ketika menghadapi kemajuan bangsa Barat. Arus deras modernisme di Barat ini menyebabkan mereka, dalam beberapa hal, lebih maju dari masyarakat muslim. ${ }^{3}$ Sedangkan masyarakat muslim sendiri, masih berjuang sekuat tenaga dalam merespon modernisme tersebut. Di satu pihak, masyarakat muslim ini menerima gagasan modernisme, sedangkan di pihak lain menunjukkan penolakan terhadap gagasan tersebut. Sikap mendua dari masyarakat muslim ini merupakan refleksi dari adanya keinginan untuk tetap berpegang teguh kepada ajaran agama yang diyakini kebenarannya (Islam), disamping tidak adanya kemampuan dari masyarakat muslim itu sendiri dalam mewujudkan independensinya terhadap kemajuan ilmu pengetahuan dan teknologi. Oleh karena itu, sikap menolak (resistance) dari masyarakat muslim terhadap modernisme

2 Syafiq A. Mughni, Dinamika Intelektual Islam Pada Abad Kegelapan (Surabaya : LPAM, 2002), 54-57.

3 Karen Armstrong, A History of God (New York : Ballantine Books, 1993), 293. 
Barat lebih disebabkan adanya self sufficiency, yaitu kepercayaan bahwa doktrin Islam sudah cukup untuk menjawab berbagai problematika dalam peradaban manusia, tidak lagi membutuhkan yang lain.

Di samping itu, doctrin finality, yang berasumsi bahwa doktrin Islam merupakan ajaran terakhir dan terlengkap, tidak boleh dikurangi ataupun ditambah, telah menjadi sebuah mentalitas masyarakat muslim. Sedangkan sikap menerima (receptive) masyarakat muslim terhadap modernisme Barat lebih disebabkan adanya absolutisme dari modernisme itu sendiri, menjadi sesuatu yang tidak bisa dipungkiri. Meskipun demikian, respon yang diberikan dalam menerima gagasan modernisme itu juga bervariasi, mulai dari yang selektif, liberal hingga sekuler. ${ }^{4}$ Kedua respon ini kemudian melahirkan dua kutub saling bertentangan, sehingga sebagian masyarakat yang lain mengambil jalan tengah (middle roads), dalam rangka meredam "perang dingin" ini.

Ketiga respon masyarakat muslim dalam menjawab modernisme Barat tersebut juga memiliki implikasi tidak kecil dalam perkembangan pendidikan. Artinya, penyelenggaraan pendidikan ketika itu lebih menunjukkan berbagai corak aliran masing-masing kelompok. Dari perbedaan ini, dikotomi modern dan tradisional mulai mengemuka dalam sistem pendidikan. ${ }^{5}$ Dikotomi itu sendiri, di sisi lain, juga mendorong sebagian kelompok untuk berupaya mengkombinasikan keduanya, sebagai middle roads, yang berupaya untuk menutupi berbagai kekurangan dari kedua sistem yang ada sekaligus mempertahankan nilai-nilai positif dari keduanya.

4 Osman Bakar, Tauhid dan Sains, terj. Yuliani Liputo (Bandung : Pustaka Hidayah, 1994), 220-221.

5 Ali Ashraf dan Sajjad Husain, Crisis in Muslim Education (Jeddah : King Abdulaziz University Press, 1979), 11-16. Bandingkan dengan Mukani, Pergulatan Ideologis Pendidikan Islam (Malang: Madani Media, 2011). 
Disadari bahwa kemunduran peradaban Islam juga disebabkan adanya perhatian yang tidak seimbang antara secular science dan religious science, maka masyarakat muslim berupaya untuk mengakhiri itu semua. Dikotomi itu sendiri tidak bisa dilepaskan dari upaya penetrasi intelektual bangsa Barat. ${ }^{6}$ Dengan dalih modernisasi, berbagai upaya telah dilakukan untuk mencapai ending adanya pemisahan yang jelas terhadap esensi ilmu. Faktor ini memberikan kontribusi terhadap pembentukan pola pikir masyarakat muslim ketika itu dalam memandang ilmu dari perspektif keyakinan agamanya (baca : Islam).

Oleh karena itu, dikotomi secular science dan religious science ini dalam perkembangannya mampu merubah pola pikir masyarakat muslim dalam beragama. Dari periode klasik yang memandang Islam sebagai suatu ajaran komprehensif, yang mengatur manusia dalam berinteraksi secara vertikal maupun horisontal, berubah menjadi sebuah pemahaman yang memandang Islam sebagai agama yang hanya berorientasi kepada ritual manusia kepada Tuhannya. ${ }^{7}$ Permasalahanpermasalahan terkait dengan kehidupan sehari-hari manusia secara langsung dan kurang bersifat transendental, dianggap sebagai "sisi lain" dari ajaran agama sehingga kurang begitu penting untuk dikaji. Pemahaman seperti ini memiliki konskuensi logis terhadap perkembangan ilmu ketika itu, yaitu berorientasi kepada pengembangan religious science, seperti fiqh, tauhid, hadits, tafsir, tarikh dan sebagainya. Sedangkan secular science, seperti logika, filsafat, kimia, kedokteran, matematika, farmasi, biologi, fisika dan sebagainya,

${ }^{6}$ Jeanne S. Mintz, Muhammad, Marx, Marhaen; Akar Sosialisme di Indonesia, terj. Zulhilmiyasari (Yogyakarta : Pustaka Pelajar, 2002), 21-23.

7 Abdul Muta'al al-Sha'idy, Al-Mujaddidun fil Islam (Kairo : Darul Hamam lil Thaba'ah, tt), 5. 
diasumsikan sebagai sesuatu yang tidak wajib dikembangkan oleh masyarakat muslim.

Dikotomi ilmu dalam masyarakat muslim ini, pada masa sekarang, telah membawa implikasi besar bagi kultur masyarakat itu sendiri. Pemahaman-pemahaman yang diturunkan dari dikotomi tersebut seolah telah menjadi sebuah dogma yang harus diwariskan kepada generasi selanjutnya. Di sisi lain, pendidikan sekarang lebih menunjukkan orientasinya dalam memberikan pengetahuan (transfer of knowledge) kepada generasi selanjutnya, sedangkan pewarisan nilai-nilai luhur yang dilakukan melalui pendidikan (transfer of values) kurang memperoleh perhatian dalam pelaksanaannya. Ini sebenarnya menjadi tugas besar untuk mengembalikan pendidikan kepada posisi ideal, disamping sebagai salah satu upaya maksimal untuk menjawab problematika yang disebabkan adanya miss-understanding yang dilakukan terhadap esensi ilmu, yang berujung kepada dikotomi antara secular science dan religious science di atas.

Upaya-upaya maksimal yang telah dilakukan ini tidak bisa dilepaskan dari realita di lapangan, yang pada masa-masa sekarang ini justru menunjukkan urgensi pelaksanaannya. Artinya, masalah-masalah yang muncul dan berkaitan erat dengan dunia pendidikan pada masa sekarang, mengharuskan pencarian solusi secara tepat dan efektif. Jika tidak, maka berbagai problematika yang ada akan menjadi beban lebih berat bagi generasi penerus. Oleh karena itu, peran pendidikan sangat signifikan dalam melahirkan generasi berkualitas yang memiliki kompetensi tertentu.

Lebih jauh dipahami bahwa pendidikan merupakan sebuah proses yang memiliki continuity dan secara sadar dilakukan untuk mempersiapkan generasi yang memiliki pengetahuan dan nilai secara seimbang. Jika mampu 
mengevaluasi terhadap program pendidikan yang telah dilaksanakan selama ini, maka justru keseimbangan (balancing) dalam proses pendidikan inilah yang sekarang menjadi masalah besar. Berbagai kasus yang menjadi sorotan masyarakat dan berkaitan erat dengan dunia pendidikan, seperti perkelahian antar siswa, komersialisasi pendidikan, kualitas guru yang masih rendah, marginalisasi masyarakat miskin dalam menikmati pendidikan dan sebagainya, merupakan rangkaian masalah yang bermuara kepada satu pertanyaan penting, sudah pincangkah pendidikan yang telah dilaksanakan selama ini?

\section{B. Prinsip bagi Pendidik}

Pendidikan, dalam perspektif Indonesia, merupakan aset paling mahal dalam membangun diri dan menjaga eksistensi. Harapan-harapan terhadap sosok "manusia prospektif" merupakan suatu hal wajar ketika melihat kompleksitas problematika dunia modern. Ekspektasi tinggi terhadap keberhasilan pendidikan untuk melahirkan manusia yang mampu mengemban tanggung jawab dan melaksanakan tongkat estafet kepemimpinan, mendorong sebuah bangsa untuk tidak pelit dalam mengalokasikan anggaran kepada sektor pendidikan.

Di sisi lain, dampak negatif dari kehidupan modern tidak dapat dihindari lagi oleh manusia modern, terutama dari aspek pendidikan. Berawal dari keberadaan something lost dalam diri yang mendorong pencarian spiritual dalam dogma agama, manusia modern telah berupaya untuk mengakhiri split personality yang dialami akibat terlalu mendewakan kekuatan rasio-materialisme. Dengan pemahaman yang tidak sempit seperti ini, manusia modern merupakan ciptaan Tuhan yang diharapkan mampu mewujudkan peran strategis sebagai 
khalifah fil 'ardh maupun 'abdullah. Namun, dalam mencari solusi terhadap berbagai problematika yang dihadapi pendidikan pada masa sekarang, mayoritas manusia modern masih terjebak kepada permasalahan-permasalahan teknis dan parsial. Kesadaran bahwa pendidikan merupakan kunci dalam membahas dan memecahkan berbagai masalah dalam bidang ekonomi, hukum, politik dan HAM, ternyata belum lahir di tengah masyarakat Indonesia. Maka, wajar jika bangsa ini masih sulit untuk keluar dari keterpurukan akibat krisis multidimensi sejak pertengahan 1997 silam.

Dalam konteks kekinian, pendidikan sebenarnya mampu memberikan jawaban terhadap berbagai masalah yang sedang dihadapi bangsa ini, meskipun masih membutuhkan waktu untuk melihat kualitas outcome pendidikan dalam menyelesaikan masalah-masalah tersebut. Jika saat ini bangsa Indonesia sedang gencar memerangi korupsi dan penyalahgunaan narkoba, maka pendidikan sebenarnya mampu mengakomodasikan hal ini kedalam kurikulum pendidikan. Begitu juga dengan kerusakan alam, budaya malas, rendahnya kualitas sumber daya manusia dan sebagainya. Pada posisi ini pendidikan diharapkan mampu mewujudkan peran dan fungsinya tersebut dengan baik.

Pendidikan merupakan aspek kehidupan yang hasilnya tidak langsung dilihat, membutuhkan waktu lama dengan disertai analisis tajam. Berbagai unsur pada pendidikan harus terus menjaga keterkaitan yang telah ada untuk mencapai tujuan yang telah ditetapkan. Partisipasi dan kepedulian masyarakat yang masih rendah terhadap kemajuan dunia pendidikan, yang lebih disebabkan kultur masyarakat yang masih menganggap bahwa tanggung jawab pendidikan murid menjadi tugas pihak sekolah semata, harus segera diakhiri. Hal ini sangat ditekankan mengingat masyarakat merupakan pihak 
yang paling berkepentingan kepada eksistensi pendidikan (stakeholders), terutama dalam mewariskan nilai-nilai luhur yang terdapat di dalam masyarakat dan mengembankan kemajuan ilmu pengetahuan dan teknologi yang telah diraih. Peran serta masyarakat terhadap kemajuan pendidikan ini semakin dirasakan seiring realisasi konsep school based management atau SBM.

Aspek utama lain yang harus segera dipersiapkan dengan baik oleh bangsa ini adalah kualitas guru. Vilfredo Pareto, dalam Social Elites and Their Circulation, menyatakan bahwa setiap masyarakat akan diperintah oleh sekelompok kecil orang yang memiliki kekuasaan dan politik secara mutlak. Kelompok ini mampu menduduki jabatan strategis dan tinggi pada semua lapisan masyarakat. Mereka terdiri dari para mekanik, advokat, preman sampai dengan para gundik. Kelompok inilah yang disebut dengan elite. Pada teori elit dan sirkulasi elit itu, Pareto menawarkan konsep yang disebut dengan dua lapisan kelas sosial masyarakat, yaitu lapisan atas yang terdiri dari kelompok elit yang sedang memerintah (governing elite) dan elit yang tidak memerintah (nongoverning elite). Sedangkan lapisan kedua adalah kelas bawah yang terdiri dari lapisan kelompok masyarakat yang dipimpin (non-elite). ${ }^{8}$

Dalam konteks pendidikan, guru sebenarnya memiliki posisi yang sangat signifikan dalam melahirkan generasi muda yang prospektif dan berkarakter, sebagaimana amanat yang tercantum pada Pembukaan UUD 1945. Dengan berposisi sebagai pendidik, guru memiliki tugas ekstra untuk membentuk outcome yang berkualitas, tidak sekedar output,

8 Baca Mukani, "Mendamba Guru Ideal Perspektif Kota Santri," Rakyat Post, 16 Juli 2009, 2. 
dan harus siap berkompetisi menghadapi bangsa-bangsa lain dalam percaturan global.

Secara konsepsional, guru memiliki tiga fungsi, yaitu kognitif, moral dan inovatif. Fungsi pertama mengharuskan guru untuk mentransferkan teori-teori ilmu pengetahuan yang dimiliki kepada para muridnya. Fungsi moral mengandung makna guru harus mampu menjaga perilaku dari muridnya, sekaligus menjadi suri teladan (uswatun hasanah) bagi para muridnya. Sedangkan fungsi inovatif berarti guru harus memiliki daya kreativitas dalam meningkatkan kualitas proses pembelajaran yang dilaksanakan bersama muridnya tersebut. ${ }^{9}$

Sebagai negara dengan penduduk mayoritas beragama Islam, Indonesia harus mampu menunjukkan eksistensi dan berbicara banyak dalam dunia internasional melalui sistem pendidikan yang dimiliki. Grand design dan mind set tersebut akan bisa terwujud jika kualitas guru mampu bersaing secara kompetitif dengan negara-negara lain. Untuk itu, diperlukan kualifikasi substantif sebelum menjadi guru, tidak sekedar persyaratan normatif-administratif sebagaimana yang telah menjadi sebuah fenomena sampai detik ini.

Agar menjadi sosok ideal di Indonesia, guru minimal harus memenuhi delapan prinsip sehingga mampu memberikan kontribusi positifnya bagi peningkatan kualitas pendidikan di negeri ini. Pertama, prinsip teologis. Sebagai sosok pendidik, guru sudah seharusnya memiliki komprehensivitas dalam menginterpretasikan doktrin agama yang diyakini, tidak sekedar belajar secara parsial dan eksklusif, yang kemudian diimplementasikan dan diinternalisasikan kedalam kehidupan keseharian. Upaya ini merupakan langkah fundamental yang sangat penting bagi guru dalam melahirkan generasi muda penerus bangsa yang prospektif, dengan

\footnotetext{
${ }_{9}^{9}$ Mukani, “Minim Karya Tapi Karya Gelar,” Rakyat Post, 1 Desember 2011, 2.
} 
disertai dedikasi yang tinggi tentunya. Prinsip teologis juga diharapkan mampu memotivasi guru untuk memiliki check and balancens dari ketiga ranah keberagamaan yang dimiliki, baik sistem kepercayaan (credo), sistem peribadatan (ritual) maupun sistem perilaku (moral).

Kedua, prinsip formal. Guru, secara normatif, harus memiliki kualifikasi pendidikan minimal sarjana S-1 atau D-4, sebagaimana diatur dalam Pasal 8 UU Nomor 14 Tahun 2005 Tentang Guru dan Dosen. ${ }^{10}$ Namun berdasar data Direktorat Jenderal PMPTK Departemen Pendidikan Nasional Republik Indonesia, pada awal tahun 2010 terdapat 2.374.722 guru di seluruh Indonesia. Dari jumlah itu, sebanyak 1.427.667 guru $(60,11$ persen) masih berijazah SLTA, sebanyak 930.804 guru (39,19 persen) berijazah sarjana, 16.196 guru (0,68 persen) sudah berijazah magister dan baru 55 guru berijazah doktor. Menurut rencana, pada tahun 2014 nanti, guru yang sudah harus berijazah sarjana sebesar 100 persen pada jenjang SLTA, 97 persen pada jenjang SLTP dan 95 persen pada jenjang SD.

Jika mau berkaca secara teliti dari kasus para guru Malaysia, yang pada 1960-an para pemudanya masih menimba ilmu (kuliah) di Indonesia, namun Malaysia sekarang sudah meninggalkan Indonesia dalam beberapa segi. Sedangkan Indonesia, setelah tahun 2000-an, hanya mampu mengirimkan generasi mudanya ke Malaysia, namun hanya sebagai tenaga kasar. Ternyata, guru di Malaysia harus berasal dari PTN, tidak boleh dari PTS. Tidak seperti di Indonesia yang carut marut dengan praktik jual beli ijazah instant, meskipun sudah dikeluarkan Surat Edaran dari Direktorat Jenderal Dikti Departemen Pendidikan Nasional Republik Indonesia Nomor 595/D/T/2007 tanggal 27 Pebruari 2007 yang melarang

10 Mukani, “Guru Bermutu dari Program Master Teacher," Majalah Media, Maret 2013, 30-31. 
praktik kuliah kelas jarak jauh dan kuliah dua hari atau week end. ${ }^{11}$

Ketiga, prinsip fungsional. Dalam melaksanakan tugas, guru harus dilandasi dengan semangat dedikasi yang tinggi untuk menunjukkan pengabdian kepada ibu pertiwi, tidak kemudian mudah terjebak kepada kepentingan pragmatis yang hanya sekedar bekerja kemudian memperoleh gaji. Di sisi lain, idealisme, kedisiplinan, kompetensi, kejujuran, progresivitas, keikhlasan, kesabaran dan komitmen yang dimiliki guru harus tetap dikembangkan dan disertai dengan upaya-upaya konstruktif untuk memajukan pendidikan di Indonesia. Dalam kehidupan berbangsa, inti dari krisis multidimensi yang dihadapi bangsa Indonesia sejak 1997 silam sebenarnya adalah masih melandanya krisis mental yang dialami rakyat di negeri ini. Pada perspektif pendidikan, sudah saatnya guru menjadi suri teladan, minimal bagi komunitas di sekitarnya, tidak lantas kemudian melakukan perbuatan yang bisa merendahkan martabatnya sendiri, sebagaimana yang dilakukan selama ini oleh sebagian oknum guru.

Keempat, prinsip kultural. Budaya membaca, menulis dan meneliti masih sangat minim dilakukan oleh para guru. Kurniawan Muhammad menulis bahwa dalam satu hari, orang Indonesia hanya melaksanakan salah satu dari ketiga aktivitas tersebut sebanyak satu persen, sedangkan 99 persen lainnya dihabiskan dengan budaya tutur (lisan). Padahal, jika mampu mengkaji historisitas bangsa-bangsa beradab di bumi ini, mereka mampu meraih kemajuan karena didukung ketiga aktivitas tersebut, terutama dalam meneliti. Pada aspek lain, karena guru dapat dikategorikan sebagai sebuah jabatan akademis, maka guru dituntut memiliki kultur intelektualisme

11 Nurul Yani, "Ijasah Instan dan Mental Pragmatis Guru," Majalah Media, Desember 2013, 63-64. 
dalam semua kesehariannya, seperti ilmiah, non-konservatif, berwawasan global, mandiri, rasional, memahami filosofi sains, dan sebagainya. ${ }^{12}$

Kelima, prinsip komprehensivitas. Konsep ini akan mendorong guru untuk melakukan pemaknaan ulang (reinterpretation) terhadap substansi pendidikan itu sendiri. Meminjam istilah Henry A. Giroux, guru harus memberikan kritik konstruktif kepada kurikulum yang telah berjalan selama ini, tidak sekedar mengimplementasikannya. ${ }^{13}$ Konsep ini memperoleh "angin segar" ketika dipahami substansi Kurikulum Tingkat Satuan Pendidikan (KTSP) Tahun 2006 yang memberikan peluang kepada guru untuk lebih menjabarkan kurikulum, disesuaikan dengan situasi dan kondisi dari masyarakat sekitar. Jika mau jujur, sebenarnya masih banyak kearifan lokal (local genous) yang belum mampu digali dari daerah-daerah di Indonesia untuk kemudian diangkat sebagai sebuah universalitas nilai yang berlaku di semua daerah. Hal ini sesuai dengan substansi pendidikan yang tidak hanya memberikan teori-teori sains (transfer of knowledge), tetapi juga berusaha mewariskan nilai-nilai luhur bangsa (transfer of values) agar lestari dan terjaga orisinalitasnya melalui implementasi kongkret dalam kehidupan sehari-hari murid.

Keenam, prinsip substansial. Sebagai sebuah profesi yang hendak disejajarkan dengan berbagai profesi yang sudah menjanjikan lainnya, seorang guru harus memiliki tiga keahlian dasar ketika mengajar, yaitu materi, metodologi dan psikologi. Keahlian pertama berkaitan dengan apa yang harus diberikan

12 Mukani, "Ironi, Pendidik Jombang Menjiplak Disertasi," Majalah Suara Pendidikan, No. 6, Pebruari 2013, 36-37.

13 Mukani, "Guru Profesional Tak Cuma Tumpuk Portofolio," Majalah Media, Oktober 2012, 34-336. 
kepada murid, yang hal ini tentu saja mengharuskan guru untuk mengikuti perkembangan sains dengan cermat. Keahlian kedua berhubungan dengan bagaimana teknik membelajarkan murid agar senang dalam belajar, sehingga hal ini mendorong guru untuk menggunakan berbagai metode mengajar secara kreatif dan tidak monoton. Keahlian terakhir berkaitan dengan kapan proses pembelajaran murid itu dilaksanakan. Artinya, guru harus memiliki pemahaman yang komprehensif terhadap kondisi kejiwaan dari murid yang akan dibelajarkannya.

Secara teoritis, kualifikasi dari prinsip substansial ini sudah diperoleh semua guru ketika menimba ilmu di perguruan tinggi. Namun, realita di lapangan tidak jarang bertolak belakang. Banyak murid yang masih mengeluhkan metode mengajar guru yang terfokus kepada ceramah, bahkan mendikte. Guru ideal harus mampu melakukan introspeksi dari proses pembelajaran yang telah dilaksanakan selama ini, tidak justru mudah puas terhadap hasil yang telah diperoleh. Hasil intropeksi itu kemudian direfleksikan dalam bentuk perbaikan teknik mengajar, yang kemudian dibuktikan dengan meningkatnya minat murid untuk mengikuti pelajaran, disebabkan karena guru yang mengajar memiliki sifat menarik dan menyenangkan. ${ }^{14}$

Ketujuh, prinsip sosial. Dalam perspektif pengembangan masyarakat, di samping sebagai pendidik murid dalam lingkungan pendidik, guru juga harus mampu memberikan kontribusi positif bagi pengembangan masyarakat di sekitarnya (community organizer). Langkah kongkret pertama yang harus dilakukan guru adalah melakukan rekonstruksi dari komunitas di sekelilingnya menjadi sebuah "laboratorium

14 Mukani, "Character Education di Indonesia," Jurnal Islamica, Vol. 1 No. 2, Maret 2007 (Surabaya : Program Pascasarjana IAIN Sunan Ampel Surabaya), 146-161. 
nyata" dalam mengimplementasikan nilai-nilai edukatif yang telah diterima saat kuliah. Guru juga harus mampu menjalin komunikasi yang aktif dengan semua lapisan masyarakat dengan berbagai variannya itu. Guru ideal tidak boleh memiliki eksklusivitas dalam berinteraksi dengan anggota masyarakat lain.

Kedelapan, prinsip identitas. Budaya yang masih dilestarikan oleh masyarakat Indonesia, harus mampu dikaji secara seksama oleh guru untuk kemudian diimplementasikan nilai-nilai yang terkandung di dalamnya sebagai sebuah identitas tersendiri yang bersumber dari local genous. Dengan demikian, di tengah percaturan global, diharapkan generasi muda sekarang masih tetap memiliki identitas. ${ }^{15}$

Jika kedelapan prinsip di atas mampu dilaksanakan secara konsisten dan kontinyu oleh para guru di Indonesia, maka tidak mustahil akan lahir banyak guru ideal di negeri ini. Pada akhirnya, kualitas guru yang terus meningkat ini akan berkorelasi positif terhadap perbaikan kualitas pendidikan di Indonesia.

\section{Reformulasi Filsafat Pendidikan}

Masa modern, yang kemudian memunculkan gelombang filsafat modern, menurut mayoritas sejarahwan diawali dari titik tolak kesadaran manusia dalam mersepon perkembangan ilmu pengetahuan dan teknologi, yang diaktualisasikan dalam masa enlightenment, atau lebih tepatnya adalah masa kebangkitan atau renaissance. Pada masa ini, individualisme telah diletakkan manusia modern sebagai pusat dunia dengan menekankan kehidupan manusia sebagai sentral dari realitas (anthropocentris). Sebagai proyek enlightenment, kehidupan

15 Mukani, “Sertifikasi, Menuju Guru Profesional?,” Kompas, 1 Oktober 2007, 6. 
modern telah diformulasikan oleh para filosofnya sejak abad XVIII Masehi dengan berupaya meraih penguasaan ilmu pengetahuan objektif, tanpa mengenal lelah. Dengan menekankan hukum universalistik yang sesuai dengan logika internal manusia dan pentingnya dasar moralitas, kehidupan modern juga mengeksplorasi berbagai potensi kognitif yang dimiliki manusia dan mencapai titik puncaknya pada penggunaan ilmu pengetahuan itu sendiri bagi kepentingan praktis manusia. ${ }^{16}$ Dengan upaya itu semua, banyak aktivitas manusia yang menjadi lebih mudah pelaksanaannya dikarenakan perkembangan ilmu pengetahuan dan teknologi yang telah sangat maju.

Di sisi lain, berbagai problematika yang sedang dihadapi pendidikan di Indonesia saat ini sebenarnya bermuara kepada semakin jauhnya manusia dari titik axis dalam dirinya. Manusia modern lebih banyak memberikan porsi waktu dan perhatiannya kepada berbagai masalah yang bersifat normatifteknis, daripada harus memikirkan ulang hal-hal prinsip dan fundamental. Karena memiliki paradigma pemikiran pragmatis seperti ini, menurut John Naisbitt, manusia modern belum mampu menemukan jati dirinya secara holistis, sehingga berujung kepada semakin dirasakannya dampak dari something lost dalam dirinya. ${ }^{17}$

16 Jurgen Habermas, "Modernity: an Unfinished Project," dalam The PostModern Reader, ed. Charles Jencks (New York : St. Martins Press, 1992), 162163.

17 Dengan pemahaman seperti ini, diprediksi peran agama di masa mendatang semakin signifikan, sehingga kejayaan era agama pada Abad Pertengahan mampu menjadi new spirit untuk menjawab split personality manusia modern. Kebangkitan era agama ini diiringi kebangkitan-kebangkitan dalam bidang lain, seperti biologi, kebudayaan, globalisasi ekonomi, nasionalisme kultur, swastanisasi negara sejahtera, kepemimpinan wanita, kebangkitan wilayah Pasifik dan sikap individualisme. John Naisbitt dan Patricia Aburdence, Megatrend 2000 (London : Sidwick, 1990). 
Berbagai problematika pendidikan merupakan suatu hal yang harus dihadapi. Berbagai dampak negatif kehidupan modern harus diminimalisasi dalam berbagai sektor kehidupan manusia modern, termasuk pendidikan. Jika hal ini mampu dipahami secara cermat, maka yang menjadi tugas utama sekarang adalah upaya menampilkan pendidikan dalam konteks modern dengan visi baru yang mampu berperan aktif dan memiliki kontribusi signifikan dalam kancah modernitas itu sendiri. Dengan demikian, upaya merenungkan dan mencermati kembali terhadap substansi pendidikan yang dilaksanakan selama ini merupakan suatu keharusan, meliputi filsafat, teori dan kurikulum pendidikan. ${ }^{18}$ Hal ini perlu memperoleh tekanan yang lebih mengingat ketiganya adalah variabel yang harus ada dalam proses pendidikan, yang berfungasi memberikan arah dan model pendidikan itu sendiri.

Filsafat pendidikan, dengan pola pemikiran yang radikal, sistematis, komprehensif dan ketat terhadap berbagai fenomena yang dihadapi, merupakan pendekatan pemikiran secara filosofis terhadap permasalahan dalam bidang pendidikan. ${ }^{19}$ Kelahiran filsafat pendidikan dilatarbelakangi adanya asumsi bahwa pendidikan merupakan sesuatu yang masih bersifat normatif, sehingga bertugas merumuskan kaidah-kaidah norma dan nilai yang akan menjadi tolok ukur untuk menilai perbuatan manusia. Oleh karena itu, dengan asumsi ini, pendidikan sangat berkaitan erat dengan ilmu-ilmu normatif, seperti agama, filsafat, kebudayaan dan sosiologi, yang semuanya bersumber dari way of life suatu masyarakat, kaidah fundamental negara dan tradisi kebudayaan bangsa.

18 Ali Maksum dan Luluk Yunan Ruhendi, Paradigma Pendidikan Universal di Era Modern dan Post-Modern (Yogyakarta : Ircisod, 2004), 283.

${ }^{19}$ Louis O. Kattsoff, Pengantar Filsafat, terj. Soerjono Soemargono (Yogyakara : Tiara Wacana, 1994), 2-7. 
Namun, di sisi lain, asumsi yang lain juga harus diberikan, yaitu bahwa filsafat pendidikan lahir karena ilmu pendidikan merupakan ilmu praktis, maka tugas pendidikan sebagai aspek kebudayaan adalah menyalurkan dan melestarikan nilai-nilai yang terdapat di masyarakat untuk dikembangkan kearah tujuan yang lebih baik dan sempurna. Dengan demikian, asumsi kedua ini bersentuhan pula dengan agama, filsafat, tradisi kebudayaan dan kaidah fundamental negara, mengingat nilai-nilai tersebut bersumber dari aspekaspek ini.

Urgensi untuk melakukan reformasi terhadap filsafat pendidikan, sebagai dasar dari sistem pendidikan yang dilaksanakan di Indonesia selama ini, merupakan suatu keharusan. Hal ini didasarkan kepada kenyataan bahwa filsafat, dalam arti umum, merupakan dasar perilaku seseorang dan juga suatu bangsa. Filsafat merupakan upaya pemahaman terhadap objeknya secara mendalam (radical), sehingga dari upaya ini lahir tindakan-tindakan yang bertugas mengaktualisasikan pemikiran filsafat yang masih abstrak tersebut. Filsafat pendidikan, sebagi cabang filsafat yang memfokuskan diri kepada permasalahan pendidikan, diharapkan mampu memberikan dasar-dasar pemikiran dalam mendidik peserta didik untuk meraih kedewasaannya. ${ }^{20}$ Peserta didik harus dilihat secara holistik, yang memiliki pengetahuan jasmani dan pengetahuan ruhani secara beriringan, tidak parsial sebagaimana yang terjadi pada masa sekarang. Keduanya harus dikembangkan oleh pendidikan secara seimbang. ${ }^{21}$

\footnotetext{
20 IR. Poedjawijatna, Pembimbing ke Arah Alam Filsafat (Jakarta : Rineka Cipta, 1997), 201-203.

21 Ibid, 187-190. 
Berdasarkan hasil pemikiran-pemikiran filosofis terhadap berbagai problematika pendidikan masa sekarang, diharapkan adanya penyusunan teori pendidikan yang baru supaya pelaksanaan pendidikan lebih terarah dan sistematis dalam mewujudkan tujuannya. Teori pendidikan ini, yang diterapkan dalam sebuah kurikulum, harus dirumuskan dengan tetap mempertimbangkan berbagai aspek yang terdapat dalam pendidikan itu sendiri, seperti pendidik, peserta didik, kurikulum, fasilitas, manajemen, materi pembelajaran, dan sebagainya. Tanpa mengesampingkan sasaran-sasaran yang bersifat teknis dan jangka pendek, dengan berpijak dari filsafat pendidikan dan teori pendidikan yang telah dirumuskan, kurikulum tentu akan mengantarkan pencapaian tujuan pendidikan yang lebih menyeluruh dan luas. Akhirnya, upaya mencari formulasi yang baru dari filsafat pendidikan menjadi suatu keharusan sebelum membahas arah dan tujuan pendidikan itu sendiri.

\section{Penutup}

Berbagai konsekwensi bermunculan dari kehidupan modern. Di samping kemudahan bagi manusia dalam menyelesaikan berbagai aktivitas, kehidupan modern juga berdampak negatif. Dikotomi secular science dan religious science, sebagai salah satu studi kasus, merubah pola pikir masyarakat muslim dalam beragama. Dari periode klasik yang memandang Islam sebagai ajaran komprehensif, berubah menjadi sebuah pemahaman yang memandang Islam sebagai agama yang hanya berorientasi kepada ritual. Dikotomi ini ternyata juga berimplikasi kepada dikotomi dalam sistem pendidikan, dalam bentuk modern dan tradisional.

Sebagai proses yang memiliki continuity dan secara sadar dilakukan untuk mempersiapkan generasi yang memiliki 
pengetahuan dan nilai secara seimbang, berbagai unsur pada pendidikan harus terus menjaga keterkaitan yang telah ada untuk mencapai tujuan yang telah ditetapkan. Partisipasi dan kepedulian masyarakat yang masih rendah terhadap kemajuan dunia pendidikan harus diakhiri, seiring realisasi konsep school based management atau SBM.

Aspek lain yang harus disiapkan adalah kualitas guru. Secara konsepsional, guru memiliki tiga fungsi, yaitu kognitif, moral dan inovatif. Agar menjadi sosok ideal di Indonesia, guru harus memenuhi delapan indikator, yaitu prinsip teologis, prinsip formal, prinsip fungsional, prinsip kultural, prinsip komprehensivitas, prinsip subtstansial, prinsip sosial dan prinsip identitas.

Urgensi untuk melakukan reformasi terhadap filsafat pendidikan, sebagai dasar dari sistem pendidikan yang dilaksanakan di Indonesia selama ini, merupakan suatu keharusan. Hal ini didasarkan kepada kenyataan bahwa filsafat merupakan dasar perilaku seseorang dan juga suatu bangsa. Penyusunan teori pendidikan yang baru diharapkan supaya pelaksanaan pendidikan lebih terarah dan sistematis dalam mewujudkan tujuannya. Teori pendidikan ini harus dirumuskan dengan tetap mempertimbangkan berbagai aspek yang terdapat dalam pendidikan itu sendiri, seperti pendidik, peserta didik, kurikulum, fasilitas, manajemen, materi pembelajaran dan sebagainya. 


\section{DAFTAR PUSTAKA}

Abdul Muta'al Al-Sha'idy, Al-Mujaddidun fil Islam (Kairo: Darul Hamam lil Thaba'ah, tt.).

Ali Ashraf dan Sajjad Husain, Crisis in Muslim Education (Jeddah: King Abdulaziz University Press, 1979).

A. Syafiq Mughni, Dinamika Intelektual Islam Pada Abad Kegelapan (Surabaya: LPAM, 2002).

Ali Maksum dan Luluk Yunan Ruhendi, Paradigma Pendidikan Universal di Era Modern dan Post-Modern (Yogyakarta: Ircisod, 2004).

Harun Nasution, Pembaharuan Dalam Islam (Jakarta: Bulan Bintang, 1992).

Jurgen Habermas, "Modernity: an Unfinished Project," dalam The Post-Modern Reader, ed. Charles Jencks (New York: St. Martins Press, 1992).

Jeanne S. Mintz, Muhammad, Marx, Marhaen; Akar Sosialisme di Indonesia, terj. Zulhilmiyasari (Yogyakarta: Pustaka Pelajar, 2002).

John Naisbit dan Patricia Aburdence, Megatrend 2000 (London: Sidwick, 1990).

Karen Armstrong, A History of God (New York: Ballantine Books, 1993).

Louis 0 Kattsoff, Pengantar Filsafat, terj. Soerjono Soemargono (Yogyakara: Tiara Wacana, 1994).

Mukani, Pergulatan Ideologis Pendidikan Islam (Malang: Madani Media, 2011).

"Mendamba Guru Ideal Perspektif Kota Santri," Rakyat Post, 16 Juli 2009.

"Minim Karya Tapi Karya Gelar," Rakyat Post, 1 Desember 2011. 
, “Guru Bermutu dari Program Master Teacher," Majalah Media, Maret 2013.

"Ironi, Pendidik Jombang Menjiplak Disertasi," Majalah Suara Pendidikan, No. 6, Pebruari 2013.

"Guru Profesional Tak Cuma Tumpuk Portofolio," Majalah Media, Oktober 2012.

, “Character Education di Indonesia," Jurnal Islamica, Vol. 1 No. 2, Maret 2007 (Surabaya: Program Pascasarjana IAIN Sunan Ampel).

, "Sertifikasi, Menuju Guru Profesional?," Kompas, 1 Oktober 2007, 6.

Nurul Yani, “Ijasah Instan dan Mental Pragmatis Guru,” Majalah Media, Desember 2013.

Osman Bakar, Tauhid dan Sains, terj. Yuliani Liputo (Bandung: Pustaka Hidayah, 1994).

Poedjawijatna, Pembimbing ke Arah Alam Filsafat (Jakarta: Rineka Cipta, 1997). 


\title{
MANUSIA DALAM KONTEKS PEDAGOGIS
}

\author{
Sutikno \\ (Kajur PI FTK UIN Sunan Ampel)
}

\begin{abstract}
Abstrak:
Secara pedagogis, manusia dipahami sebagai makhluk yang diciptakan oleh Allah SWT untuk dididik dan mendidik. Oleh karena itu manusia itu sebagai subjek (pelaku) dan objek (sasaran) daripada pendidikan itu sendiri. Manusia adalah makhluk yang memiliki perasaan dan kepekaan luar biasa. Melalui pendidikan manusia dapat mengasah perasaan dan mencapai ilmu pengetahuan, melalui ilmu pengetahuan manusia dapat menciptakan sebuah kebudayaan. Oleh karena ilmunya, manusia menjadi orang yang mengetahui. Oleh karena banyaknya pengetahuan yang dimiliki manusia, maka iapun menjadi banyak dibutuhkan oleh manusiamanusia lain. Ketika manusia banyak dibutuhkan oleh manusia-manusia lain, maka posisinya pun menjadi terhormat. Kehormatannya akan mencapai derajat yang tinggi -baik di sisi Allah SWT maupun di sisi makhluk-Nyaapabila disertai dengan keimanan dan amal shaleh.
\end{abstract}

Kata Kunci: Manusia, Ilmu, dan, Pedagogis

\section{A. Pendahuluan}

Manusia adalah makhluk Allah SWT. Ia dan alam semesta bukan terjadi dengan sendirinya, tetapi dijadikan oleh Allah SWT. Allah menciptakan manusia untuk mengabdi kepada-Nya. Untuk ini Allah SWT memerintahkan supaya 
manusia itu beribadah kepada-Nya. ${ }^{1}$ Orang yang beribadah kepada Allah SWT adalah orang yang disayangi-Nya. Kepadanya diturunkan suatu ajaran melalui Rasul-Nya secara berturut dan beruntun, mulai dari Rasul pertama, Adam a.s. sampai kepada Rasul terakhir, Muhammad SAW.

Ajaran yang telah disempurnakan melalui Rasul terakhir ini benama Syari'at Islam yang terkumpul dalam suatu kitab yang bemama Al-Quran, dan yang telah dijelaskan oleh Rasulullah dengan sabda, perbuatan, dan pengakuannya, seterusnya dikembangkan oleh para pengikutnya yang sudah memiliki kemampuan untuk berijtihad. Melalui ajaran ini umat Islam mengetahui pandangan Islam mengenai manusia.

Omar Muhammad Al-Toumy Al-Syaibani memandang manusia manusia dengan delapan prinsip kepercayaan: (1) Kepercayaan bahwa manusia makhluk yang termulia di jagat raya ini, (2) Kepercayaan akan kemuliaan manusia, (3) Kepercayaan bahwa manusia itu ialah hewan yang berpikir, (4) Kepercayaan bahwa manusia itu mempunyai tiga dimensi: badan, akal dan ruh, (5) Kepercayaan bahwa manusia dalam pertumbuhannya terpengaruh oleh faktor-faktor warisan (pembawaan) dan alam lingkungan, (6) Kepercayaan bahwa manusia itu mempunyai motivasi dan kebutuhan, (7) Kepercayaan bahwa ada perbedaan perseorangan di antara manusia, (8) Kepercayaan bahwa manusia itu mempunyai keluasan sifat dan selalu berubah. ${ }^{2}$ Prinsip-prinsip tersebut digali dari Al-Quran dengan memahaminya dari berbagai aspek penafsiran dan kenyataan yang dapat dihayati.

\footnotetext{
${ }^{1}$ Q.S. Adz-Dzariyat: 56.

2 Omar Muhammad Al-Toumy Al-Syaibani, Falsafah Pendidikan Islam, Terj. Hasan Langgulung (Jakarta: Bulan Bintang, 1979).
} 


\section{B. Penciptaan Manusia dalam Tinjauan Historis}

Dalam kitab suci Al-Quran disebutkan, bahwa ketika Tuhan hendak menciptakan manusia (khalifah di atas bumi), Dia berdialog dengan malaikat. Malaikat mempunyai persepsi buruk tentang keberadaan makhluk baru itu. Akan tetapi Tuhan akan memberikan pengajaran atau pendidikan kepadanya. Anda bisa mempelajarinya lebih dalam lagi melalui tafsir Al-Qur'an Surat Al-Baqarah, ayat 31.3 Tuhan telah menciptakan Adam di dalam surga dengan aturan tidak boleh mendekati dan memakan buah pohon khuldi. Akan tetapi ketika Adam mendapatkan pasangannya bernama Hawa, dia tergoda oleh bujuk rayu pasangannya itu untuk mendekati dan memakan buah larangan itu. Atas pelanggarannya tersebut Adam dan Hawa diturunkan dari surga ke atas bumi. Jadilah mereka penghuni bumi pertama yang datang dari tempat lain, kemudian dilanjutkan dengan anak keturunannya. Anak keturunannya diciptakan dari sel-sel sperma dan ovum sebagaimana akan diterangkan nanti. ${ }^{4}$

Kehidupan Adam dan keturunannya ini mempunyai peran besar dalam kehidupan di bumi ini, dengan mengelola, memanfaatkan dan melestarikannya. Peran itu diwujudkan pula untuk pengembangan diri dan lingkungannya supaya mempunyai dukungan positif terhadap kehidupannya. Peranperan itu kemudian ditransformasikan kepada generasi berikutnya melalui pendidikan. Oleh karena itu, pendidikan tidak pernah lepas dari manusia dan selalu berpusat pada manusia dan kehidupannya, baik sebagai subjek maupun objek. Tiada pendidikan tanpa manusia dan tiada manusia tanpa pendidikan. Hubungan manusia dengan pendidikan ini bersifat

${ }^{3}$ QS. Al-Baqarah: 31.

${ }^{4}$ Imam Al-Ghazali, Memahami Hikmah Penciptaan Makhluk, Terjemahan Nur Faizin (Yogyakarta: Mitra Pustaka, tt.), 79. 
simbiosis, manusia mengembangkan pendidikan dan pendidikan mengembangkan manusia dan kehidupannya.

Pandangan lain menyebutkan bahwa Adam yang datang dari surga itu bukan bersifat fisik. Aspek fisik manusia termasuk Adam berasal dari benda-benda bumi dan berkembang secara evolusionis seperti yang dikemukakan oleh Ibn Maskawih, seorang filosof besar muslim. Tuhan menurunkan ruh kepada benda-benda tertentu untuk menjadi manusia. Boleh jadi manusia secara fisik berkembang secara evolusionis dan pada saat ia mencapai kematangannya ia mendapatkan ruh, sehingga jadilah manusia yang berdimensi fisik dan psikis. ${ }^{5}$

Spekulasi semacam ini tidak berhenti sampai di sini, sebagaimana diperanggapkan oleh sains dan agama. Bahkan pandangan tentang penciptaan manusia masuk juga dalam wilayah filsafat, yang menyatakan bahwa asal muasal alam ini termasuk manusia di dalamnya berasal dari Tuhan. Dalam teori Creatio ex Nihilo (penciptaan dari tiada) dikatakan bahwa pada mulanya hanyalah Tuhan yang ada. Tuhan tidak didampingi oleh siapa pun dan oleh apa pun. Pada suatu ketika, dalam kesendirian-Nya, Dia menciptakan sesuatu dari tiada, maka sesuatu menjadi ada di samping keberadaan-Nya. Artinya terdapat perbedaan/tenggang waktu dari keberadaan Tuhan dengan keberadaan makhluk-Nya, walaupun keberadaan-Nya tidak dapat ditentukan waktunya. Akan tetapi keberadaan makhluk-Nya jauh setelah keberadaan-Nya; pada suatu saat Tuhan berkehendak untuk menciptakan makhluk-Nya.

Dalam kajian filosofis, penciptaan manusia oleh Tuhan berproses secara emanatif (pancaran). ${ }^{6}$ Tuhan sebagai Wujud

5 Abdul Kadir, dkk., Dasar-Dasar Pendidikan (Surabaya: LAPIS-PGMI-Amanah Pustaka, 2009), 8.

${ }^{6}$ Hasyimsyah Nasution, Filsafat Islam (Jakarta: Gaya Media Pratama, 1999), 35. 
al-Awwal (wujud pertama); keberadaan-Nya bersifat wajib (Wajib al-Wujud). Dalam wacana filsafat Paripatetik, Tuhan sebagai Wajib al-Wujud (wajib adanya atau wujud-Nya sebagai suatu keharusan), yaitu wujud yang harus ada dan tidak boleh tidak, serta dzat dan wujudnya adalah identik. Wajib al-Wujud ini disebut pula dengan Al-'Aql. Al-'Aql ini adalah dzat yang berpikir, dan yang dipikirkan adalah dirinya sendiri karena tiada yang lebih berhak untuk dipikirkan kecuali dirinya sendiri. Oleh karena Dia berpikir, maka Dia disebut dengan Al'Aqil (yang berpikir), dan karena yang dipikirkan dirinya sendiri, maka Dia pula disebut dengan Al-Ma'qul (yang dipikirkan).

Tuhan sebagai wujud pertama berpikir tentang diri-Nya sendiri. Ketika Tuhan berpikir semacam ini, maka terjadilah emanasi. ${ }^{7}$ Emanasi dari Tuhan sebagai Al-Wujud al-Awwal (wujud pertama), memanifestasikan Al-Wujud al-Tsani (wujud kedua) atau Al-'Aql al-Awwal (akal pertama). Ketika akal pertama ini berpikir tentang Tuhan, timbullah emanasi kedua yang berupa Al-Wujud al-Tsalits (wujud ketiga) atau Al-'Aql alTsani (akal kedua), dan ketika ia berpikir tentang dirinya sebagai Al-Mumkin al-Wujud, maka timbullah Al-Sama' al-'Ula (langit pertama). Setelah itu, ketika berpikir tentang dirinya sebagai wajib al-Wujud dan sebagai emanasi dari Tuhan, timbullah jiwa semesta. Dengan proses yang sama, Al-'Aql alTsani itu beremanasi dan menimbulkan 'aql-'aql lain, sehingga sampai pada Al-'Aql al-'Asyir (akal kesepuluh). Di bawah al-'Aql ini, sebagai pengatur dunia, muncul jiwa dan materi pertama sebagai unsur alam.

Dalam proses yang hampir sama seperti di atas, AlSuhrawardi (filosof yang masuk dalam madzhab 'Isyraqi), memandang, bahwa posisi tertinggi dari rentetan cahaya

${ }^{7}$ Sudarsono, Filsafat Islam (Jakarta: Rineka Cipta, 1997), 38. 
adalah Cahaya segala Cahaya atau Cahaya Murni. Dengan proses emanasi Cahaya segala Cahaya itu memanifestasikan cahaya pertama (disebut juga dengan Cahaya Abstrak atau AlNur al-Aqrab atau Cahaya lebih dekat), jumlahnya satu dan tidak semurni sumbernya, sehingga terdapat sisi kegelapan padanya. Kegelapan ini menimbulkan bayangan pertama tertinggi. Ketika ia memahami kekurangannya, muncullah cahaya kedua yang menerima pencerahan dari Cahaya segala Cahaya dan cahaya pertama, karena semua cahaya bersifat tembus. Dengan proses yang sama seperti di atas timbullah cahaya-cahaya dan ismus-ismus yang lain dalam rentetan yang tidak terbatas. Manusia secara material berasal dari ismus itu yang mendapatkan pancaran cahaya dari cahaya-cahaya di atasnya. Pancaran cahaya itu merupakan aspek ruhani manusia. ${ }^{8}$

Dalam wacana sufisme, dinyatakan, bahwa penciptaan pertama adalah Nur Muhammad (cahaya Muhammad) atau sering pula disebut dengan Al-Haqiqah al-Muhammadiyah (hakikat kemuhammadan), ruh Muhammad, atau Al-'Aql alAwwal, karena ia identik dengan akal pertama dalam teori filsafat. Sebelum Tuhan menciptakannya Ia melihat dirinya sendiri lebih dahulu. Dalam kesendiriannya terjadi dialog antara Tuhan dengan diri-Nya yang di dalamnya tidak terdapat kata-kata ataupun huruf. Dia melihat kemuliaan dan ketinggian dzat-Nya, dan Ia pun cinta pada dirinya sendiri, yaitu cinta yang tidak dapat disifatkan. Cinta inilah yang menjadi sebab wujud bagi yang banyak. Oleh karena cinta yang mendalam dari Yang Maha Esa untuk dikenal dan menjadi kenyataan, maka Tuhan mewahyukan dirinya dalam bentuk dunia fenomena. Cinta abadi-Nya untuk memandang kecantikan dan kesempurnaan diri-Nya dimanifestasikan dalam bentuk-bentuk untuk

\footnotetext{
${ }^{8}$ Hasyimsyah Nasution, Filsafat Islam, 146.
} 
diketahui oleh diri-Nya sendiri di dalam dan melalui diri-Nya sendiri. Ia mengeluarkan dari tiada bentuk copy dari diri-Nya yang mempunyai segala sifat dan nama-Nya. ${ }^{9}$

Hakikat kemuhammadan adalah ketuhanan dalam bentuk tanazul (penurunan) yang pertama kali dan menjadi sumber tanazul-tanazul berikutnya. Dia adalah tempat tajalli (penampakan diri) Tuhan yang bersifat Absolut. Dalam kesendirian-Nya, Dia ingin melihat diri-Nya di luar diri-Nya, sehingga diciptakanlah alam ini sebagai cermin bagi diri-Nya. Dengan kata lain, Dia berkehendak untuk diketahui, maka Dia menampakkan dirinya dalam bentuk tajalli. Prosesnya terjadi bahwa Dzat-Nya ber-tajalli dalam tiga martabat melalui sifat dan asma-Nya yang paling sempurna, dan Dia adalah Al-'Ilmu al-Ilahi (pengetahuan Tuhan) yang meliputi semua hakikat ketuhanan, sehingga ia bisa dikatakan Al-'Aql (akal), Al-'Aqil (yang berakal), dan $A l-M a^{\prime} q u l$ (objek yang dipikirkan). Nur Muhammad merupakan wadah tajalli (penampakan Tuhan) karena tidak bertabir, penampakan lahir (revelation), atau pencerahan (ilumination) yang paling sempurna. Tidak satu pun yang mengatasinya kecuali esensi Yang Absolut.

Cahaya Muhammad ini bersifat azali (ada tanpa permulaan), karena ia merupakan pancaran cahaya-Nya. Keazaliannya mendahului Al-'Adam (ketiadaan), karena ia muncul pertama kali, dan keberadaannya mendahului semua makhluk, sehingga menjadi wajar bilamana posisinya disebut sangat dekat dengan Tuhan dan sebagai al-wasilah (penghubung) Tuhan yang pertama kali. Nur Muhammad adalah ciptaan Tuhan yang pertama dari cahaya-Nya yang menjadi sumber makhluk, sebagai perantara antara hamba

9 A. E. 'Afifi, Filsafat Mistis Ibn 'Arabi, Terj. Syahrir Mawi dan Nandi Rahman (Jakarta: Gaya Media Pratama, 1995). 
dengan-Nya. Ia sebagai sebab dari semua penciptaan, ruh suci, dan aktivitas penciptaan dari Tuhan. ${ }^{10}$

Nur Muhammad sebagai awal atau permulaan ruh dan sebagai sumber akal pikiran, dan segala sesuatu tercipta darinya. Dia adalah intermedier (barzakh) antara Tuhan dengan fenomena, suatu untaian antara yang abadi dengan yang temporal, yang wajib dengan yang kontingen, yang riil dengan yang fenomenal, yang aktif dengan yang pasif. Satu pihak ia berhadapan dengan Tuhan dan pihak yang lain ia berhadapan dengan makhluk. Nur Muhammad merupakan prinsip aktif dari pengetahuan kudus dan esoterik, atau menjadi sumber ilmu dan Al-'Irfan (pengenalan kepada Tuhan).

Tuhan sebagai pencipta dunia tidak memerintah langsung karena Dia bersifat transenden mutlak. Fungsi ini diperankan oleh ciptaan yang mewakili arketip Muhammad yang penciptaannya sesuai dengan bayangan Tuhan dan dianggap sebagai daya kosmik, tempat bergantung tata susunan dan pemeliharaan alam semesta. Ia sebagai axis (pusat) tempat segala sesuatu mengitarinya dari awal hingga akhir. Penampakan Tuhan secara esensial itu dikhususkan kepada Muhammad dan bukan kepada selainnya. ${ }^{11}$

Alam berada dalam hubungan yang paling dekat dengan Tuhan dan diketahui melalui dirinya sendiri, yakni alam adalah kesadaran Tuhan sendiri, merupakan substansi dari pengetahuan, dan yang mengetahui (the knower), yang diketahui (the known) dan pengetahuan (the knowledge) adalah satu. Tentu seseorang tidak dapat mengenal semua dzat yang disebutkan di atas melalui pancainderanya. Hal ini disebabkan karena dzat-dzat itu bersifat immateri, sesuatu yang tidak bisa dicerna melalui indera yang mana pun. Alasan-alasan filosofis

${ }^{10}$ Abdul Kadir, dkk., Dasar-Dasar Pendidikan, 10-11.

11 A. E. 'Afifi, Filsafat Mistis Ibn 'Arabi. 
sebagaimana diterangkan di atas hanya bisa dimengerti oleh rasio, sehingga kebenarannya bersifat rasional.

\section{Memahami Eksistensi Manusia}

Manusia dapat dipandang dari sudut yang beragam. Satu sisi dapat dipandang sebagai realitas fisik, dan sisi yang lain dapat dipandang sebagai realitas psikis.

\section{Aspek Fisik Manusia}

Pandangan satu pihak tentang manusia lebih menekankan pada realitas dan fungsi-fungsi jasmani. Anggapan demikian menunjukkan bahwa keberadaan dan kehidupan manusia sangat ditentukan oleh fisiknya. Aspek jasmani yang terdiri atas benda (materi) tunduk kepada hukum-hukum materi atau hukum-hukum alam yang bekerja secara mekanik. Keberadaannya berasal dari alam dan bekerja menurut hukum alam. Semua yang dikerjakan dan diperbuat oleh manusia merupakan kausalitas alami tanpa diintervensi oleh aspek lainnya.

Keberadaan manusia di alam ini sebatas/sepanjang umurnya sesuai dengan ketentuan Tuhan yang telah diletakkan dalam hukum alam. Manusia tidak dapat menahan diri atau menolak hukum alam. Sebagaimana manusia tidak dapat menahan diri dan tidak dapat menolak untuk menjadi tua, karena menjadi tua adalah hukum alam yang tidak mungkin dihindari. Secara fisiologis (jasmani), keturunan manusia diciptakan dari sel-sel sperma yang bersatu dengan sel-sel telur (ovum) dalam rahim seorang ibu yang mengandungnya, sehingga kemudian menjadi segumpal darah, darah kemudian menjadi daging, dan daging membentuk tulang-belulang sampai hari 
kelahirannya mencapai kelengkapan fisiologis yang diperlukan untuk hidup. ${ }^{12}$

Hal demikian terjadi secara alami. Akan tetapi hal ini belum menjawab pertanyaan dari manakah manusia pertama yang menjadi sebab lahirnya manusia lainnya sebagaimana menjadi teka-teki di atas. Tentunya manusia pertama tidak terdiri dari pencampuran sperma dan ovum sebagaimana terjadi pada keturunannya. Kalau setiap sperma dan ovum berasal dari manusia, maka akan terjadi peristiwa yang berkelanjutan tanpa ada batasnya (et infinitum). Aspek fisik/jasmani manusia yang hidup di alam ini tunduk kepada hukum alam, sehingga ia memerlukan penyesuaian diri dengan tuntutan hukum-hukum alam. Keberlanjutan kehidupannya hanya bisa terwujud bilamana kebutuhan fisiknya secara alami dapat terpenuhi, seperti makan, minum, menghirup udara dan lain sebagainya. Barangkali manusia dapat menyebutkan beberapa kebutuhan primer (utama) manusia serta kebutuhan sekunder sebagaimana yang dialami. Akan tetapi, aspek fisik ini mempunyai kemampuan untuk meneruskan atau melanjutkan keturunannya dengan cara berkembang biak melalui fungsi-fungsi biologisnya. Fungsi ini tidak terdapat pada aspek lainnya. Aspek biologis sebagaimana disebutkan tadi bersifat fisik/ materi, sehingga dapat diketahui dan diserap melalui indera. Manusia tentu sudah tahu kegunaan dan fungsi masing-masing kelengkapan dan anggota aspek fisik, seperti: mata untuk melihat, telinga untuk mendengar, hidung untuk membau dan lain sebagainya. Semua organ

12 Muhammad Fahmi, "Manusia dalam Islam: Tela'ah Filosofis atas Pemikiran al-Ghazali", Akademika: Jurnal STudi Keislaman, Volume 17, Nomor 1, September (Surabaya: PPs IAIN Sunan Ampel, 2005), 15. 
tubuh dan aspek lainnya secara bersinergi satu dengan lainnya menunjang kehidupan manusia.

Bagaimana kemudian fungsi jantung, paru-paru, ginjal dan organ tubuh lainnya yang telah bekerja secara sistemik dalam menunjang kehidupan manusia. Tentu ingat ketika belajar biologi di SD/MI, SMP/MTs, maupun di SMA/MA. Untuk sekedar menyegarkan kembali ingatan, cobalah sekarang buka lagi buku biologi yang dulu itu, dan tentunya Anda mampu untuk membuat ringkasan tentang fungsifungsi masing-masing organ tubuh dalam menunjang kehidupan manusia.

\section{Aspek Psikis Manusia}

Pandangan lain lebih menekankan pada realitas dan fungsi-fungsi ruhani. Aktivitas dan perbuatan manusia secara lahir sangat ditentukan oleh aspek ruhaninya, karena aspek jasmani hanya merupakan bayangan atau pengejawantahan dari realitas ruhani. ${ }^{13}$ Aspek ini dianggap telah ada sebelum manusia lahir ke dunia ini; dan akan melanjutkan kehidupannya di akhirat nanti ketika jasadnya sudah meninggal dunia. Kehidupan ruhani yang telah mengalami kehidupannya sebelum hidup di dunia ini dan terus akan hidup secara ruhani walaupun jasadnya sudah mati adalah lebih penting. ${ }^{14}$ Oleh karena itu, aspek manusia tidak bersifat fisik semata sebagaimana dideskripsikan di atas. Pengamatan terhadap aspek fisik semata tidak dapat menjelaskan manusia secara utuh, bahkan tidak mencukupi untuk memperjelas konsep manusia, karena manusia tidak diwakili oleh aspek fisiknya belaka.

13 Muhammad Fahmi, "Manusia dalam Islam:..., 17.

${ }^{14}$ Abu Hamid Muhammad bin Muhammad Al-Ghazali, Misykah al-Anwar (Kairo: Dar al-Qudsiyah, 1969). 
Untuk mengetahui lebih lanjut dimensi lain dari manusia ikuti uraian berikut. "Manusia menyebut dirinya dengan aku. Apa yang disebut aku oleh manusia bukan yang bersifat fisik, karena aspek fisik itu hanyalah bagian dari aku, seperti rambutku, kepalaku, mataku, hidungku, telingaku dan lain-lain. Ketika bagian-bagian fisik itu terlepas dari manusia, maka aku manusia masih utuh; dan manusia masih dapat menyebut dirinya dengan diriku. Diri manusia tidak hilang bersamaan dengan hilangnya bagian-bagian fisik itu. Akan tetapi kalau seluruh tubuh itu hilang semua, maka manusia tidak dapat menyebut dirinya aku lagi, bukan hilangnya diri manusia saja, tetapi karena yang merepresentasikan diri manusia tidak ada".

Dengan demikian, ada dimensi lain dari diri manusia yang tidak bersifat fisik, dan sering disebut dengan psikis (ruhani), sehingga manusia terdiri dari aspek jasmani dan ruhani yang terintegrasi. Manusia lebih mudah dikenal secara fisik, seperti mengenal benda lainnya. Aspek fisik manusia bisa dikenal melalui pancaindera. Disisi lain, aspek lainnya hanya dikenal dengan argumen-argumen logis yang hanya bisa dicerap oleh kemampuan rasionalitas yang cukup tinggi, atau melalui beberapa pengenalan yang tidak melalui pancaindera ataupun rasio, tetapi melalui kemampuan batin. Kadang-kadang modalitas ini disebut dengan hati sebagaimana akan diperbincangkan nanti. Secara totalitas, manusia adalah makhluk yang diciptakan. Ada beberapa pandangan tentang penciptaan manusia.

Manusia tentu sangat lupa terhadap pengalaman batinnya ketika masih berada di alam sebelum alam ini atau alam ruhani, dan belum dapat membayangkan apa yang akan terjadi pada dirinya kelak setelah meninggalkan alam ini, karena semuanya bersifat immateri/ruhani yang berada 
di alam akhirat. Hal yang bersifat akhirati ini tidak dapat dicerna oleh indera manusia. Akan tetapi, penjelasanpenjelasan yang berhubungan dengan masalah akhirat dapat diterima oleh akal yang sehat atau melalui keyakinan terhadap berita-berita akhirat yang tersebut dalam kitab suci yang dipercayai.

Aspek ruhani manusia adalah sesuatu yang tidak bersifat fisik/materi (immateri). Coba sekarang berpikir sejenak tentang diri manusia. Secara fisik manusia terdiri dari tubuh dan beberapa organ tubuh dengan fungsinya masing-masing. manusia telah dapat menyebutkan organorgan tubuh dan anggota tubuh beserta fungsinya masingmasing. Kadang-kadang manusia juga dapat menyebut dirinya lebih dari sekedar nama dan fungsinya, misalnya, unsur-unsur fisika dan kimianya. Meski demikian, setelah manusia melihat tubuhnya dengan kelengkapan organ dan anggotanya secara total, yakinkah bahwa itu dirinya? Sebagaimana disebutkan di atas bahwa manusia barangkali masih bimbang untuk meninggalkan aspek ruhani sebagai bagian dari dirinya. ${ }^{15}$

Bagian-bagian tubuh atau organ-organ tubuh yang satu dengan yang lain tidak bersentuhan sehingga yang satu tidak merasakan keberadaan yang lain. Demikan pula alat pencerapan, seperti mata ditutup sehingga tidak melihat pada bagian mana pun dari tubuh seseorang. Telinganya pun disumbat sehingga tidak mendengar detak jantung. Demikian pula dengan alat-alat yang lain. Kalau seseorang mau memperhatikan secara seksama, pada waktu itu masih ada sesuatu yang masih mengenal dirinya melalui kesadarannya bahwa seseorang ada. Ketika seseorang sadar

15 Abdul Kadir, dkk., Dasar-Dasar Pendidikan, 14. 
akan dirinya, maka orang tersebut mengetahui eksistensinya.

Kesadaran itu sebagai representasi manusia. Kesadaran itu bukan terletak pada fisik manusia, tetapi pada ruhani manusia. ${ }^{16}$ Kalau sudah yakin demikian, maka sebenarnya pengetahuan terhadap aspek psikis lebih rumit dibandingkan pengetahuan manusia terhadap aspek fisiknya. Aspek psikis manusia terdiri dari beberapa bagian walaupun tidak dapat diperlihatkan dan diketahui melalui pancaindera. Untuk sekadar mengetahuinya, sebagian orang hanya menatap gejala-gejala psikis yang tampak ke permukaan atau melalui aspek jasmaniahnya, seperti orang marah mukanya merah, orang senang banyak tersenyum dan lain sebagainya.

Meskipun begitu, kadang-kadang seseorang membuat kamuflase untuk menyembunyikan gejala jiwanya. Seperti orang marah tetap tersenyum, dan orang susah tetap tertawa. Hal demikian mendorong sebagian orang lain melihat gejala psikis seseorang melalui kajian filosofis. Aspek kejiwaan atau aspek ruhani (spiritual) adalah sesuatu yang lain dari tubuh dan bentuk-bentuknya berbeda dengan bentuk tubuh. Secara etimologis spiritual berarti jiwa, sesuatu yang immaterial, supramaterial. Makna etimologis semacam ini meliputi atau mengandung term al-ruh (spirit, soul), al-nafs (mind, soul, psyche, spirit), al-qalb (mind, soul, spirit), dan al-'aql (reason, insight, mind, intelect, intelegence). Al-'aql masuk dalam makna spirit atas padanan kata dari istilah al-nafs yang diberikan oleh para filosof. Penggunaan arti spiritual bisa terjadi tumpang tindih atau bergeser dari makna yang satu ke makna yang lain sesuai

\footnotetext{
16 Ha'iri Yazdi Mehdi, Ilmu Hudhuri (Bandung: Mizan, 1985). 
dengan fungsi dan kedudukannya, karena ia mewakili banyak term.

Aspek jiwani/spiritual merujuk pada bagian dalam dari pandangan dualisme manusia yang mengatakan bahwa manusia mempunyai aspek fisik dan psikis. Kawasan semantik kata spiritual atau jiwa ini meliputi beberapa term yang berbeda, walaupun kadang-kadang mengacu pada makna yang sama. Dalam pandangan al-Ghazali, aspek spiritual diwakili oleh term al-ruh (ruh), al-qalb (hati), alnafs (jiwa), dan al-'aql (akal) yang semuanya merupakan sinonim. ${ }^{17}$ Aspek spiritual adalah esensi manusia, terpisah dari fisik dan mempunyai potensi untuk mengetahui dan mengalami, serta sebagai subjek penerima informasi dari dalam maupun dari luar dirinya. Keberadaannya mengambil tempat (sekadar membedakan dengan aspek fisik yang mengambil ruang dan waktu) di 'alam al-barzakh (alam perantara) atau di 'alam al-amr (alam perintah) atau 'alam al-awwal (alam pertama). Wawasan tentang bentuk spiritualitas manusia menggambarkan keberadaan Tuhan, karena sifat manusia merupakan pantulan sifat-sifat Tuhan, tidak dibatasi oleh ruang dan waktu serta terbebas dari kategori jumlah dan kualitas, bentuk, warna, ukuran dan lain sebagainya, sehingga kadang-kadang sulit untuk membentuk konsepsi tentang esensi ini.

Al-nafs adalah substansi spritual yang berdiri sendiri dan berasal dari alam ketuhanan, sehingga ia mampu mengenal dirinya sendiri dan ia tahu bahwa dirinya tahu. ${ }^{18}$ Seperti itu pula pandangan Ibn Maskawaih tentang al-nafs,

\footnotetext{
17 Muhammad Yasir Nasution, Manusia Menurut al-Ghazali (Jakarta: Raja Grafindo, 1996).

18 Muhammad Fahmi, "Nalar Kritis terhadap Konsep Nagsi Al-Ghozali", Academia: Jurnal Pemikiran, Pendidikan dan Kebudayaan Islam, Vol. 1, No. 2, September (Probolinggo: Lemlit IAI Nurul Jadid, 2006), 13.
} 
walaupun Ibn Rusyd melihatnya sebagai aktivitas dan pengetahuan rasional. Al-nafs ini terdiri dari dua substansi al-qalb dan al-ruh. Al-qalb (hati) adalah al-lathifah alrabbaniyah (kelembutan Tuhan) sebagai instrumen pencerapan pengertian ruhaniah guna mendapatkan pengalaman dan pengetahuan esoterik dan sebagai pusat pewahyuan. Ia dapat menjadi tempat ma'rifah (mengenal Allah), karena memang dipersiapkan untuk memandang keindahan Ilahi. Hati dianggap sebagai batas dan tempat pikiran yang sangat rahasia dan murni. Ia merupakan dasar yang paling dalam dari sifat pengetahuan. Kalau pada suatu ketika manusia menerima inspirasi ghaib yang tidak melalui pancaindera maupun pikiran, maka ia menerimanya melalui hati, sebagaimana terjadi pada orang suci dan wali.

Al-ruh dalam pandangan Suhrawardi sama dengan al'Aql al-Mustafad, sebagai prinsip rasional dan sebagai mode universal, dan berupa substansi kemalaikatan dan sebagai hakikat manusia, berfungsi mencari pengetahuan sejati. Ia dipersiapkan untuk mencintai Allah dan menerima cahaya dari-Nya. Cahaya itu dapat memancar ke seluruh bagian manusia bagaikan pelita dalam kamar, tanpa meninggalkan tempatnya, tetapi sinarnya menebar ke seluruh penjuru ruangan, sehingga ia merupakan kelengkapan pengetahuan yang tertinggi, dan bertanggung jawab terhadap cahaya penglihatan murni. Sebagian orang menerima pancaran cahaya suci yang datang dari alam ghaib. Pancaran ini memberikan pencerahan kepada seseorang sehingga segala sesuatu menjadi jelas. Tidak ada sesuatu yang bisa diketahui tanpa adanya cahaya. Akan tetapi melalui aspek ruhaninya, manusia akan mendapatkan pencerahan batin sehingga ia tahu sesuatu melalui pencerahan itu. 
Al-'Aql merupakan substansi tunggal yang tak dapat dibagi, besifat spiritual, dan sebagai alat pencerapan pengertian ruhaniah yang dapat memahami dan membedakan kebenaran dan kepalsuan. ${ }^{19}$ Ia merupakan bagian yang merasakan pengetahuan. Walaupun terpisah dari materi (tubuh), ia memerlukan materi untuk pergerakannya. Al-'aql yang merupakan cahaya Ilahi ini mempunyai kemampuan untuk menyerap makna yang tidak dapat ditangkap oleh indera. Kemampuan akal ini bertingkat-tingkat dari yang terendah sampai yang tertinggi. Term-term yang dibedakan secara definitif ini sering dipergunakan dalam makna yang sama.

\section{Manusia sebagai Khalifah di Muka Bumi}

Pendapat yang menganggap bahwa manusia itu sebagai khalifah di muka bumi, bersumber pada firman Allah SWT., yang artinya: "Dan ingatlah, ketika Tuhanmu berkata kepada para malaikat"; "Sesungguhnya aku akan menjadikan seorang khalifah di muka bumi......"20

Allah SWT memberitahukan kepada para malaikat bahwa Dia akan menciptakan manusia yang diserahi tugas menjadi khalifah di bumi. Kedudukan manusia sebagai khalifah ini dipertegas dalam ayat al-Quran yang artinya; "Kemudian Kami jadikan kamu sebagai khalifah (pengganti) di bumi ini sesudah mereka, untuk kami perhatikan bagaimana kamu berbuat".21

Lebih tegas lagi Allah SWT menyatakan dalam firmanNya yang artinya; "Dialah (Allah) yang telah menjadikan kamu sebagai penguasa di bumi, ditinggikan derajat sebagianmu dari

${ }^{19}$ Muhammad Fahmi, "Manusia dalam Islam:..., 18.

20 Q.S. Al-Baqarah: 30.

${ }^{21}$ Q.S. Yunus: 14. 
yang lain untuk mengujimu tentang apa saja yang telah dianugerahkan kepadamu".22

Setelah bumi diciptakan, Allah memandang perlu bumi itu didiami, diurus. diolah. Untuk itu ia menciptakan manusia yang diserahi tugas dan jabatan khalifah. Kemampuan bertugas ini adalah suatu anugerah Allah dan sekaligus merupakan amanat yang dibimbing dengan suatu ajaran. yang pelaksanaannya merupakan tanggung jawab manusia yang bemama khalifah itu. Untuk itu Allah telah menciptakan manusia sebagai makhluk yang lengkap dan utuh dengan sarana yang lengkap. Dalam Al-Quran Allah menegaskan: "Dia (Allah) telah menjadikan untukmu pendengaran, penglihatan dan hati, supaya kamu dapat bersyukur. ${ }^{23}$

Islam melihat manusia secara keseluruhan, tidak memisah-misahkannya pada bagian-bagian, Rasulullah SAW bersabda: "Sesungguhnya Allah tidak memperhatikan bentuk rupamu, tidak pula bangsa keturunanmu, tidak pula harta milikmu, tetapi Ia (Allah) memperhatikan hati dan perbuatanmu".24

Perintah menjalankan syariat Islam dan bertanggung jawab ditujukan kepada manusia yang utuh dan lengkap itu, bukan pada jiwanya saja, atau pada raganya saja. Islam tidak hanya memandang seseorang sebagai individu yang utuh dan lengkap saja, tetapi .juga sebagai anggota masyarakat. Memang Allah mewajibkan manusia hidup berkelompok-kelompok untuk saling berkenalan dan hidup bersama. Sebagaimana firman-Nya yang artinya;

"Hai manusia, sesungguhnya Kami telah menciptakan kamu dari seorang laki-laki dan seorang perempuan; Kami jadikan

${ }^{22}$ Q.S. Al-An'am: 105

${ }^{23}$ Q.S. An-Nahl: 78.

${ }^{24}$ H.R. Tabrani. 
kamu hidup berbangsa-bangsa dan bersuku-suku supaya kamu saling mengenal; Sesungguhnya orang yang termulia di antara kamu di sisi Allah ialah orang yang paling takwa; Sesungguhnya Allah Maha Mengetahui lagi Maha Mengenal."25

Sebagai anggota masyarakat, manusia harus bertanggung jawab. Ia mendiami dan mengurus bumi dengan bekerja, memelihara dan mengolahnya untuk diambil manfaatnya. Allah SWT berfirman, yang artinya;

"Siapa saja yang mengerjakan perbuatan jahat, pekerjaan itu tidak akan dibalas kecuali dengan kejahatan yang seimbang dengan kejahatannya; Dan siapa yang mengerjakan amal saleh, baik Iaki-laki ataupun perempuan sedang ia dalam keadaan beriman, ia akan dimasukkan ke dalam surga yang akan diberi rezeki di dalamnya tanpa hisab." 26

Dalam kaitan itu, Rasulullah Muhammad SAW bersabda: "Masing-masing kamu adalah pengembala (pemimpin) dan masing-masing kamu harus bertanggung jawab atas kepemimpinanmu itu". ${ }^{27}$

Tanggung jawab itu perlu untuk memelihara dan mengembangkan ketenteraman dan kelestarian manusia dan alam lingkungan seluruhnya. Allah menciptakan bumi dalam keadaan seimbang dan serasi. Keteraturan alam dan kehidupan ini diamanatkan kepada manusia untuk memelihara dan mengembangkannya demi kesejahteraan hidup mereka sendiri. Tugas itu dimulai oleh manusia dari dirinya sendiri, kemudian istri dan anak serta keluarganya, tetangga dan lingkungannya, masyarakat dan bangsanya. Untuk itu ia harus mendidik diri

25 Q.S. Al-Hujurat: 13.

${ }^{26}$ Q.S. Al-Mukmin: 40.

${ }^{27}$ H.R. Bukhari. 
dan anaknya serta membina kehidupan keluarga dan rumah tangganya sesuai dengan ajaran Islam. Ia harus memelihara lingkungan dan masyarakatnya, mengembangkan dan mempertinggi mutu kehidupan bersama, kehidupan bangsa dan negara. Itulah tugas khalifah Allah dalam mengurus dan memelihara alam semesta ini. ${ }^{28}$

Lebih jelas lagi Allah memerintahkan supaya manusia itu berusaha mencari bekal untuk hidup di akhirat (beribadat), tanpa melupakan kebutuhan hidup di dunia ini, dan dilarang berbuat kerusakan. Allah SWT berfirman, yang artinya:

"Dan carilah bekal untuk kehidupan di akhirat dalam karunia yang telah diberikan oleh Allah kepadamu, dan jangan kamu lupakan kebutuhan hidupmu di dunia ini. Berbuat baiklah (kepada siapa dan apapun), sebagaimana Allah telah berbuat baik kepadamu. Janganlah kamu berbuat kerusakan di bumi ini. (Ingatlah!) Allah tidak suka kepada orang yang berbuat kerusakan." 29

\section{E. Manusia adalah Makhluk yang Mulia}

Manusia diciptakan oleh Allah SWT sebagai penerima dan pelaksana ajaran Islam yang dibawa oleh Rasulullah Muhammad SAW. Oleh karena itu ia ditempatkan pada kedudukan yang mulia. Sesuai dengan kedudukannya yang mulia itu, Allah menciptakan manusia dalam bentuk fisik yang bagus dan seimbang. Untuk mempertahankan kedudukannya yang mulia dan bentuk pribadi yang bagus itu, Allah memperlengkapinya dengan akal dan perasaan yang memungkinnya menerima dan mengembangkan ilmu pengetahuan, dan membudayakan ilmu yang dimilikinya. Ini

\footnotetext{
28 Zakiah Daradjat, dkk, Ilmu Pendidikan Islam, Cet. ke 8 (Jakarta: Bumi AksaraDepag RI, 2008), 14.

${ }^{29}$ Q.S. Al-Qashash: 77.
} 
berarti bahwa kedudukan manusia sebagai makhluk yang mulia itu karena (1) akal dan perasaan, (2) ilmu pengetahuan dan (3) kebudayaan, yang seluruhnya dikaitkan dengan pengabdian kepada Allah SWT. Uraian tentang akal dan perasaan, ilmu pengetahuan, dan kebudayaan dapat dilihat di bawah ini. ${ }^{30}$

\section{Akal dan Perasaan}

Setiap orang menyadari bahwa ia mempunyai akal dan perasaan. Akal pusatnya di otak, di gunakan untuk berpikir. Perasaan pusatnya di Hati, digunakan untuk merasa dan dalam tingkat paling tinggi ia melahirkan "Kata Hati". Dalam kenyataan, keduanya sukar dipisahkan. Orang merasa dan sekaligus berfikir; hasil rumusan pikiran dapat dirasakan dan diyakini kebenarannya. Hasil kerja pikiran dapat memberikan rasa kenikmatan. Perasaan kecewa dan sedih dapat mempengaruhi kegiatan pikiran. Demikian terjalinnya pemakaian akal (pikiran) dan perasaan ini, sehingga kadangkadang kurang jelas mana yang berfungsi diantara keduanya, apakah hati atau akal. ${ }^{31}$

Meskipun rasa itu secara umum berasal dari gejala yang merangsang alat dria, namun ia selalu melalui pengolahan akal-pikiran untuk selanjutnya diteruskan ke hati. Penggunaan akal dan perasaan dapat menentukan kedudukan seseorang dalam lingkungan sosialnya, dapat membuat dia senang dan marah. Kemampuan berpikir dan merasa ini merupakan nikmat anugerah Allah yang paling besar, dan ini pula yang membuat manusia menjadi istimewa dan mulia dibandingkan dengan makhluk yang lain. Allah menyuruh orang menggunakan kemampuan

30 Zakiah Daradjat, dkk, Ilmu Pendidikan Islam, 3-15.

31 Ahmad Tafsir, Filsafat Umum: Akal dan Hati Sejak Thales Sampai James (Bandung: PT Remaja Rosdakarya, 1990). 
berpikir ini sebaik-baiknya, baik berpikir tentang diri manusia itu sendiri atau tentang alam semesta. ${ }^{32}$ Oleh karena akal merupakan alat untuk menuntut ilmu, dan ilmu merupakan alat untuk mempertahankan eksistensi manusia, maka Islam memerintahkan manusia untuk menuntut ilmu, bukan saja ilmu agama, tetapi juga ilmu-ilmu yang lain.

\section{Ilmu Pengetahuan}

Pengetahuan adalah sesuatu yang diketahui oleh manusia melalui pengalaman, informasi, perasaan atau intuisi. ${ }^{33}$ Ilmu pengetahuan merupakan hasil pengolahan akal (berpikir) dan perasaan tentang sesuatu yang diketahui itu. ${ }^{34}$ Sebagai makhluk berakal manusia mengamati sesuatu. Hasil pengamatan itu diolah sehingga menjadi ilmu pengetahuan. Dengan ilmu pengetahuan itu dirumuskannya ilmu baru yang akan digunakannya dalam usaha memenuhi kebutuhan hidupnya dan menjangkau jauh di luar kemampuan fisiknya. Demikian banyak hasil kemajuan ilmu pengetahuan yang membuat.manusia dapat hidup menguasai alam ini.

Demi mempertahankan kemuliaannya, umat Islam diperintahkan untuk menuntut ilmu dalam waktu yang tidak terbatas selama hayat di kandung badan. Prinsip belajar selama hidup ini merupakan ajaran Islam yang penting. Rasulullah Muhammad SAW bersabda: "Tuntutlah ilmu itu sejak dari ayunan sampai ke liang lahat (mulai dari kecil sampai mati). ${ }^{35}$

\footnotetext{
32 Harun Nasution, Akal dan Wahyu dalam Islam (Jakarta: UI, 1982).

33 C.A. Qadir, Filsafat dan Ilmu Pengetahuan dalam Islam (Jakarta: Pustaka Obor Indonesia, 2002), 16.

34 Zakiah Daradjat, dkk, Ilmu Pendidikan Islam, 5.

35 H.R. Ibn. Abd. Bar.
} 
Lebih tegas lagi, Islam mewajibkan orang menuntut ilmu, berdasarkan sabda Rasulullah SAW yang artinya; "Menuntut ilmu adalah kewajiban atas setiap orang Islam, laki-laki ataupun perempuan". 36

Dalam Al-Qur'an, Allah SWT juga menegaskan kedudukan yang mulia bagi orang yang berilmu. Allah SWT berfirman, yang artinya; "Katakanlah (ya Muhammad), tidaklah sama orang yang berilmu dan orang yang tidak berilmu! Sesungguhnya yang memiliki akal pikiranlah yang dapat menerima pelajaran". 37

Allah SWT meninggikan derajat orang yang berilmu, sebagaimana firman Allah yang artinya; "(Allah) meninggikan derajat orang yang beriman di antara kalian dan orang yang diberikan Imu pengetahuan beberapa derajat". ${ }^{38}$

Berbagai contoh peristiwa alam dan benda-benda yang ada di dunia ini, tidak dapat dipikirkan dan diolah oleh manusia untuk kepentingan hidupnya dan untuk memperkuat imannya, kecuali oleh orang yang berilmu yang menggunakan ilmunya. Allah SWT berfirman, yang artinya; "Itulah berbagai contoh perumpamaan yang Kami berikan kepada manusia, tidak ada yang dapat memikirkannya (untuk kepentingan hidupnya), kecuali orang yang berilmu".39

Faktor terbesar yang membuat makhluk manusia itu mulia adalah karena ia berilmu. Ia dapat hidup senang dan tenteram karena memiliki ilmu dan menggunakan ilmunya. Ia dapat menguasai alam ini dengan ilmunya. Iman dan takwanya dapat meningkat dengan ilmu juga. Rasulullah

${ }^{36}$ H.R. Bukhari dan Muslim.

37 Q.S. Az-Zumar: 9.

${ }^{38}$ Q.S. Al-Mujadalah: 11.

${ }^{39}$ Q.S. Al-Ankabut 43. 
SAW bersabda: "Siapa yang ingin dunia (hidup di dunia dengan baik), hendaklah ia berilmu; siapa yang ingin akhirat (hidup di akhirat nanti dengan senang) hendaklah ia berilmu; siapa yang ingin keduanya, hendaklah berilmu".40 Jadi manusia itu mulia dalam pandangan Allah SWT karena iman dan ilmu yang bermanfaat.

\section{Kebudayaan}

Akibat dari manusia menggunakan akal pikiran, perasaan dan ilmu pengetahuannya adalah tumbuh dan berkembangnya kebudayaan, baik berbentuk sikap, tingkah laku, cara hidup ataupun berupa benda, irama, bentuk dan sebagainya. Semua yang terkumpul dalam otak manusia yang berbentuk ilmu pengetahuan adalah kebudayaan. Di samping untuk kesejahteraan dan ketenangan, kebudayaan juga dapat berbahaya dalam kehidupan. Budaya yang menurut pikiran dan perasaan semata, tanpa pertimbangan norma etika dan agama, akan menimbulkan bahaya, baik bahaya itu pada pelakunya sendiri, maupun pada orang lain atau kelompok lain.

Kebudayaan harus diikat dengan norma etika dan agama. Agama Islam dipandang tidak saja sebagai pengikat, melainkan juga sebagai sumber suatu kebudayaan. Kebudayaan Islam diciptakan oleh orang Islam sendiri. Mengingat orang Islam berpikir dan bertindak sesuai dengan pedoman yang digariskan oleh ajaran Islam. ${ }^{41}$

Islam memandang manusia sebagai makhluk pendukung dan pencipta kebudayaan. Dengan akal, ilmu dan perasaan, ia membentuk kebudayaan, dan sekaligus mewariskan kebudayaannya itu kepada anak dan

\footnotetext{
${ }^{40}$ H.R. Imam Ahmad.

41 Zakiah Daradjat, dkk, Ilmu Pendidikan Islam, 7. 
keturunannya, kepada orang atau kelompok lain yang dapat mendukungnya. Kesanggupan mewariskan dan menerima warisan ini merupakan anugerah Allah SWT yang menjadikan makhluk manusia itu mulia. Allah SWT berfirman, yang artinya: "Demikianlah (kata Tuhan), Kami mewariskan semua itu kepada kaum yang lain".42 Allah SWT juga berfirman, yang artinya: "Akan kami jadikan mereka itu pemimpin dan penerima waris". 43 Pewaris berarti penerus dan penyambung kebudayaan dan selanjutnya, meningkatkan dan mengembangkan kebudayaan itu.

\section{F. Manusia dalam Konteks Pedagogis}

Maksud dari makhluk pedagogis adalah makhluk Allah SWT yang dilahirkan membawa potensi dapat dididik dan dapat mendidik. Makhluk itu adalah manusia. Dialah yang memiliki potensi dapat dididik dan mendidik sehingga mampu menjadi khalifah di bumi, pendukung dan pengembang kebudayaan. Ia dilengkapi dengan fitrah Allah, berupa bentuk atau wadah yang dapat diisi dengan berbagai kecakapan dan keterampilan yang dapat berrkembang, sesuai dengan kedudukannya sebagai makhluk yang mulia. Pikiran, perasaan dan kemampuannya berbuat merupakan komponen dari fitrah itu. Itulah Fitrah Allah yang melengkapi penciptaan manusia. Allah SWT berfirman, yang artinya; “ ... (Tegakkanlah) fitrah Allah yang telah menciptakan manusia berdasarkan fitrah itu. Tidak ada perubahan pada ciptaan Allah itu......". 44

Fitrah Allah yang berbentuk potensi itu tidak akan mengalami perubahan dengan pengertian bahwa manusia terus dapat berpikir, merasa dan bertindak dan dapat terus

\footnotetext{
${ }^{42}$ Q.S. Ad-Dukhan: 28.

${ }^{43}$ Q.S. Al-Qashash: 5.

${ }^{44}$ Q.S. Al-Rum 30.
} 
berkembang. Fitrah inilah yang membedakan antara manusia dengan makhluk Allah lainnya dan fitrah ini pulalah yang membuat manusia itu istimewa dan lebih mulia yang sekaligus berarti bahwa manusia adalah makhluk pedagogik. ${ }^{45}$ Allah memang telah menciptakan semua makhluk-Nya ini berdasarkan fitrah-Nya. Akan tetapi fitrah Allah untuk manusia yang di sini diterjemahkan dengan potensi dapat dididik dan mendidik, memiliki kemungkinan berkembang dan meningkat sehingga kemampuannya dapat melampaui jauh dari kemampuan fisiknya yang tidak berkembang. ${ }^{46}$

Walaupun begitu, jika potensi itu tidak dikembangkan, niscaya ia akan kurang bermakna dalam kehidupan. Oleh karena itu perlu dikembangkan dan pengembangan itu senantiasa dilakukan dalam usaha dan kegiatan pendidikan. Teori nativis dan empiris yang dipertemukan oleh Kerschenteiner dengan teori konvergensinya, telah ikut membuktikan bahwa manusia itu adalah makhluk yang dapat dididik dan dapat mendidik. Dengan pendidikan dan pengajaran potensi itu dapat dikembangkan.

Manusia -meski dilahirkan seperti kertas putih, bersih belum berisi apa-apa dan meski ia lahir dengan pembawaan yang dapat berkembang sendiri- namun perkembangan itu tidak akan maju kalau tidak melalui proses tertentu, yaitu proses pendidikan. Kewajiban mengembangkan potensi itu merupakan beban dan tanggung jawab manusia kepada Allah. Kemungkinan pengembangan potensi itu mempunyai arti bahwa manusia mungkin dididik, sekaligus mungkin pula bahwa pada suatu saat ia akan mendidik. Kenyataan dalam sejarah memberikan bukti bahwa memang manusia itu secara

\footnotetext{
2006), 84-85.

45 Zakiah Daradjat, dkk, Ilmu Pendidikan Islam, 16-17.

46 M. Jindar Wahyudi, Nalar Pendidikan Qurani (Yogyakarta: Apeiron Philotes, 
potensial adalah makhluk yang pantas dibebani kewajiban dan tanggung jawab, menerima dan melaksanakan ajaran Allah SWT.

Setiap umat Islam dituntut supaya beriman dan beramal sesuai dengan petunjuk yang digariskan oleh Allah dan RasulNya. Akan tetapi petunjuk itu tidak datang begitu saja kepada setiap orang, seperti kepada para Nabi dan Rasul, melainkan harus melalui usaha dan kegiatan. Oleh karena itu, usaha dan kegiatan membina pribadi agar beriman dan beramal adalah suatu kewajiban mutlak. Usaha dan kegiatan itu disebut pendidikan dalam arti yang umum. Dengan kalimat lain dapat dikatakan bahwa pendidikan ialah usaha dan kegiatan pembinaan pribadi. Adapun materi, tujuan dan prinsip serta cara pelaksanaannya dapat dipahami dalam petunjuk Allah yang disampaikan oleh para Rasul-Nya.

Pendidikan Islam berarti upaya untuk melakukan pembentukan pribadi muslim. Isi pribadi muslim itu adalah pengamalan sepenuhnya atas ajaran Allah dan Rasul-Nya. Pribadi muslim itu tidak akan tercapai atau terbina kecuali dengan pengajaran dan pendidikan. Membina pribadi muslim adalah wajib, karena pribadi muslim tidak mungkin terwujud kecuali dengan pendidikan, maka pendidikan itupun menjadi wajib dalam pandangan Islam.

Kaidah umum dalam ilmu Syari'at Islam berlaku pada kegiatan pendidikan. Sebuah kaidah dalam ushul fiqih menyatakan: "Sesuatu perbuatan wajib yang tidak sempurna kecuali dengannya, maka sesuatu itu adalah wajib" (Kaidah Ushul Fiqih).

Dalam ajaran Islam bertkwa itu wajib, tetapi tidak mungkin bertakwa itu tercapai kecuali dengan pendidikan, 
maka pendidikan itu menjadi wajib. ${ }^{47}$ Manusia adalah makhluk pedagogik, maka kewajiban menyelenggarakan pendidikan adalah kewajiban Syar'i yang berarti bahwa perintah bertakwa adalah sekaligus perintah menyelenggarakan pendidikan yang menuju kepada pembinaan manusia bertakwa.

\section{G. Penutup}

Dalam konteks pedagogis, manusia dipahami sebagai makhluk yang diciptakan oleh Allah SWT untuk dididik dan mendidik. Oleh karena itu manusia itu sebagai subjek (pelaku) dan objek (sasaran) daripada pendidikan itu sendiri. Manusia adalah makhluk yang memiliki perasaan dan kepekaan luar biasa. Melalui pendidikan manusia dapat mengasah perasaan dan mencapai ilmu pengetahuan, melalui ilmu pengetahuan manusia dapat menciptakan sebuah kebudayaan.

Oleh karena ilmunya, manusia menjadi orang yang mengetahui. Oleh karena banyaknya pengetahuan yang dimiliki manusia, maka iapun menjadi banyak dibutuhkan oleh manusia-manusia lain. Ketika manusia banyak dibutuhkan oleh manusia-manusia lain, maka posisinya pun menjadi terhormat. Kehormatannya akan mencapai derajat yang tinggi -baik di sisi Allah SWT maupun di sisi makhluk-Nya- apabila disertai dengan keimanan dan amal shaleh.

\footnotetext{
47 Zakiah Daradjat, dkk, Ilmu Pendidikan Islam, 18.
} 


\section{DAFTAR PUSTAKA}

Al-Quran al-Karim

Al-Hadits al-Nabawy

Abu Hamid Muhammad bin Muhammad Al-Ghazali, Misykah alAnwar (Kairo: Dar al-Qudsiyah, 1969).

Abdul Kadir, dkk., Dasar-Dasar Pendidikan (Surabaya: LAPISPGMI-Amanah Pustaka, 2009).

Ahmad Tafsir, Filsafat Umum: Akal dan Hati Sejak Thales Sampai James (Bandung: PT Remaja Rosdakarya, 1990).

A. E. 'Afifi, Filsafat Mistis Ibn 'Arabi, Terj. Syahrir Mawi dan Nandi Rahman (Jakarta: Gaya Media Pratama, 1995).

C.A. Qadir, Filsafat dan Ilmu Pengetahuan dalam Islam (Jakarta: Pustaka Obor Indonesia, 2002).

Ha'iri Yazdi Mehdi, Ilmu Hudhuri (Bandung: Mizan, 1985).

Harun Nasution, Akal dan Wahyu dalam Islam (Jakarta: UI, 1982).

Hasyimsyah Nasution, Filsafat Islam (Jakarta: Gaya Media Pratama, 1999).

Imam Al-Ghazali, Memahami Hikmah Penciptaan Makhluk, Terjemahan Nur Faizin (Yogyakarta: Mitra Pustaka, tt.).

Muhammad Fahmi, "Manusia dalam Islam: Tela'ah Filosofis atas Pemikiran al-Ghazali", Akademika: Jurnal Studi Keislaman, Volume 17, Nomor 1, September (Surabaya: PPs IAIN Sunan Ampel, 2005).

"Nalar Kritis terhadap Konsep Nagsi Al-Ghozali", Academia: Jurnal Pemikiran, Pendidikan dan Kebudayaan Islam, Vol. 1, No. 2, September (Probolinggo: Lemlit IAI Nurul Jadid, 2006).

Muhammad Yasir Nasution, Manusia Menurut al-Ghazali (Jakarta: Raja Grafindo, 1996).

M. Jindar Wahyudi, Nalar Pendidikan Qurani (Yogyakarta: Apeiron Philotes, 2006). 
Sutikno

Omar Muhammad Al-Toumy Al-Syaibani, Falsafah Pendidikan Islam, Terj. Hasan Langgulung (Jakarta: Bulan Bintang, 1979).

Sudarsono, Filsafat Islam (Jakarta: Rineka Cipta, 1997).

Zakiah Daradjat, dkk, Ilmu Pendidikan Islam, Cet. ke 8 (Jakarta: Bumi Aksara-Depag RI, 2008). 